\title{
De arbeidsmarkt naar opleiding en beroep tot 2002
}

\author{
Citation for published version (APA):
}

Researchcentrum voor Onderwijs en Arbeidsmarkt, ROA. (1997). De arbeidsmarkt naar opleiding en beroep tot 2002: Statistische bijlage. Researchcentrum voor Onderwijs en Arbeidsmarkt, Faculteit der Economische Wetenschappen. ROA Reports No. 007B https://doi.org/10.26481/umarep.1997007B

\section{Document status and date:}

Published: 01/01/1997

DOI:

10.26481/umarep.1997007B

Document Version:

Publisher's PDF, also known as Version of record

\section{Please check the document version of this publication:}

- A submitted manuscript is the version of the article upon submission and before peer-review. There can be important differences between the submitted version and the official published version of record.

People interested in the research are advised to contact the author for the final version of the publication, or visit the DOI to the publisher's website.

- The final author version and the galley proof are versions of the publication after peer review.

- The final published version features the final layout of the paper including the volume, issue and page numbers.

Link to publication

\footnotetext{
General rights rights.

- You may freely distribute the URL identifying the publication in the public portal. please follow below link for the End User Agreement:

www.umlib.nl/taverne-license

Take down policy

If you believe that this document breaches copyright please contact us at:

repository@maastrichtuniversity.nl

providing details and we will investigate your claim.
}

Copyright and moral rights for the publications made accessible in the public portal are retained by the authors and/or other copyright owners and it is a condition of accessing publications that users recognise and abide by the legal requirements associated with these

- Users may download and print one copy of any publication from the public portal for the purpose of private study or research.

- You may not further distribute the material or use it for any profit-making activity or commercial gain

If the publication is distributed under the terms of Article $25 \mathrm{fa}$ of the Dutch Copyright Act, indicated by the "Taverne" license above, 


\section{Statistische Bijlage \\ De arbeidsmarkt naar opleiding en beroep tot 2002}

ROA-R-1997/7B

Researchcentrum voor Onderwijs en Arbeidsmarkt

Faculteit der Economische Wetenschappen en Bedrijfskunde

Universiteit Maastricht

Maastricht, oktober 1997 
Niets uit deze uitgave mag worden verveelvoudigd en/of openbaar gemaakt door middel van druk, fotokopie, microfilm, of op welke wijze ook, zonder voorafgaande schriftelijke toestemming van de directeur van het Researchcentrum voor Onderwijs en Arbeidsmarkt. In geval van overname van het datamateriaal moet telkens duidelijk als bron worden vermeld: "Researchcentrum voor Onderwijs en Arbeidsmarkt" of "ROA". Van publicaties waarin gebruik wordt gemaakt van gegevens uit deze Statistische Bijlage ontvangen wij gaarne een exemplaar.

Hoewel de grootst mogelijke zorg is besteed aan de inhoud van dit rapport, kan het ROA in generlei opzicht verantwoordelijkheid op zich nemen voor eventuele onvolledigheden of onjuistheden. 


\section{Inhoud}

Bladzijde

Voorwoord

Toelichting bij gebruik

iii

\section{INFORMATIE OVER BEDRIJVEN}

\section{Tabellen}

1.1 Aantal werkenden per bedrijfssector, gemiddelde 1995-1996

1.2 Percentage vrouwen per bedrijfssector, gemiddelde 1995-1996 2

1.3 Percentage allochtonen per bedrijfssector, gemiddelde 1995-1996 3

1.4 Percentage jongeren (15-29 jaar) en ouderen (50-64 jaar) per bedrijfssector, gemiddelde 1995-1996

1.5 Percentage werkenden naar opleidingsniveau per bedrijfssector, gemiddelde 1995-1996

1.6 Deeltijdarbeid per bedrijfssector, gemiddelde 1995-1996 7

1.7 Flexibel en vast werk per bedrijfssector, gemiddelde 1995-1996 8

1.8 Zelfstandigen per bedrijfssector, gemiddelde 1995-1996 9

1.9 Belangrijkste beroepsgroepen per bedrijfssector, gemiddelde 1995-1996 10

1.10 Belangrijkste opleidingstypen per bedrijfssector, gemiddelde 1995-1996 16

1.11 Conjunctuurgevoeligheid per bedrijfssector $\quad 22$

1.12 Verwachte uitbreidingsvraag per bedrijfssector, 1997-2002 23

1.13 Verwachte knelpunten op middellange termijn in de personeelsvoorziening naar bedrijfssector

\section{INFORMATIE OVER BEROEPEN}

Tabellen

2.1 Aantal werkenden per beroepsgroep, gemiddelde 1995-1996 33

$2.2 \quad$ Percentage vrouwen per beroepsgroep, gemiddelde 1995-1996 37

2.3 Percentage allochtonen per beroepsgroep, gemiddelde 1995-1996 40

2.4 Percentage jongeren (15-29 jaar) en ouderen (50-64 jaar) per
beroepsgroep, gemiddelde 1995-1996

2.5 Percentage werkenden naar opleidingsniveau per beroepsgroep,

2.6 Deeltijdarbeid per beroepsgroep, gemiddelde 1995-1996 53

2.7 Flexibel en vast werk per beroepsgroep, gemiddelde 1995-1996 56

2.8 Zelfstandigen per beroepsgroep, gemiddelde 1995-1996 60

$2.9 \quad$ Belangrijkste bedrijfssectoren per beroepsgroep, gemiddelde 1995-1996 64

2.10 Uitwijkmogelijkheden naar verschillende bedrijfssectoren per

2.11 Belangrijkste opleidingstypen per beroepsgroep, gemiddelde 1995-1996 82 
2.12 Substitutiemogelijkheden tussen mensen met uiteenlopende opleidingsachtergronden per beroepsgroep, gemiddelde 1995-1996 97

2.13 Conjunctuurgevoeligheid per beroepsgroep 101

2.14 Verwachte uitbreidingsvraag per beroepsgroep, 1997-2002 104

2.15 Verwachte vervangingsvraag per beroepsgroep, 1997-2002 107

2.16 Verwachte baanopeningen per beroepsgroep, 1997-2002 111

\section{INFORMATIE OVER OPLEIDINGEN}

Tabellen

3.1 Aantal werkenden per opleidingstype, gemiddelde 1995-1996

3.2 Arbeidsmarktpositie potentiële beroepsbevolking naar opleidingstype, gemiddelde 1995-1996

3.3 Participatie schoolverlaters in vervolgopleidingen per opleidingsrichting, 1996

3.4 Percentage schoolverlaters met een intredewerkloosheid van 4 maanden of langer per opleidingsrichting, 1996

3.5 Werkloosheid onder schoolverlaters per opleidingsrichting, percentages 1996

3.6 Percentage vrouwen per opleidingstype, gemiddelde 1995-1996

3.7 Percentage allochtonen per opleidingstype, gemiddelde 1995-1996

3.8 Percentage jongeren (15-29 jaar) en ouderen (50-64 jaar) per opleidingstype, gemiddelde 1995-1996

3.9 Deeltijdarbeid per opleidingstype, gemiddelde 1995-1996 150

3.10 Deeltijdarbeid onder werkzame schoolverlaters per opleidingsrichting, $1996 \quad 154$

3.11 Flexibel en vast werk per opleidingstype, gemiddelde 1995-1996 157

3.12 Percentage werkzame schoolverlaters met een vast dienstverband per opleidingsrichting, 1996

3.13 Zelfstandigen per opleidingstype, gemiddelde 1995-1996 164

3.14 Gemiddeld bruto maandloon van werkzame schoolverlaters per opleidingsrichting, 1996

3.15 Percentage werkzame schoolverlaters met een functie in de eigen vakrichting per opleidingsrichting, 1996

3.16 Onderbenutting van werkzame schoolverlaters per opleidingsrichting, 1996

3.17 Belangrijkste beroepsgroepen per opleidingstype, gemiddelde 1995-1996

3.18 Uitwijkmogelijkheden naar verschillende beroepsgroepen per opleidingstype, gemiddelde1995-1996

3.19 Belangrijkste bedriffssectoren per opleidingstype, gemiddelde 1995-1996

3.20 Uitwijkmogelijkheden naar verschillende bedrijfssectoren per opleidingstype, gemiddelde 1995-1996

3.21 Overzicht opleidingstypen waarvan op de markt sterke concurrentie wordt ondervonden, gemiddelde 1995-1996

3.22 Conjunctuurgevoeligheid per opleidingstype

3.23 Verwachte uitbreidingsvraag per opleidingstype, 1997-2002 219

3.24 Verwachte vervangingsvraag per opleidingstype, 1997-2002 223

3.25 Verwachte baanopeningen per opleidingstype, 1997-2002 227

3.26 Verwachte instroom van schoolverlaters per opleidingstype, 1997-2002 231

3.27 Indicator toekomstige arbeidsmarktperspectieven (ITA) en Indicator toekomstige knelpunten in de personeelsvoorziening (ITKP) naar opleidingstype in 2002 


\section{Voorwoord}

Deze Statistische Bijlage bij het rapport De arbeidsmarkt naar opleiding en beroep tot 2002 (ROA-R-1997/7) geeft een systematisch overzicht van de verwachte arbeidsmarktontwikkelingen en de actuele arbeidsmarktgegevens die ten grondslag liggen aan het hoofdrapport. Vanuit het Informatiesysteem Onderwijs-Arbeidsmarkt van het ROA wordt over de volle breedte van de arbeidsmarkt informatie gegeven, verbijzonderd naar 35 bedrijfssectoren, 127 beroepsgroepen en 104 opleidingstypen. De opleidingeninformatie is aangevuld met meer specifieke arbeidsmarktinformatie over de schoolverlaters van het AVO, VBO, MBO, $\mathrm{HBO}$ en WO.

Deze Statistische Bijlage bestaat evenals voorgaande jaren uit drie delen, die betrekking hebben op de arbeidsmarktinformatie naar bedrijfssector, beroep en opleiding. In deze drie delen wordt achtereenvolgens arbeidsmarktinformatie gepresenteerd met betrekking tot de persoonskenmerken van de werkenden, de functiekenmerken, de substitutiemogelijkheden op de arbeidsmarkt en de conjunctuurgevoeligheid van de werkgelegenheid en de voor de periode 1997-2002 verwachte arbeidsmarktontwikkelingen. In aanvulling hierop wordt bij de bedrijfssectoren informatie gegeven over de verwachte knelpunten in de personeelsvoorziening. Bij de opleidingen wordt aanvullende informatie gepresenteerd met betrekking tot de huidige en de toekomstige aansluitingsproblemen op de arbeidsmarkt. Tevens wordt de opleidingeninformatie op een aantal punten aangevuld met actuele schoolverlatersinformatie.

In een aantal tabellen wordt ook een kwalitatieve typering gegeven van de gepresenteerde informatie. Bij de actuele arbeidsmarktinformatie wordt tevens een indicatie gegeven van de trend in de afgelopen jaren. Bij de informatie over beroepen en opleidingen gaat het hierbij in principe om de ontwikkeling in de periode 1992-1996. Door het ontbreken van de benodigde informatie over de eerste jaren van deze periode, is er bij de bedrijven echter slechts gekeken naar de ontwikkeling in de jaren 1994-1996. De informatie over de trendmatige ontwikkeling heeft meestal betrekking op de ontwikkeling van het aandeel van de desbetreffende categorie. Alleen bij de tabellen 1.1, 2.1 en 3.1 gaat het om de ontwikkeling van het aantal werkenden.

De arbeidsmarktgegevens met betrekking tot de werkzame bevolking zijn afkomstig uit de Enquête Beroepsbevolking (EBB) van het Centraal Bureau voor de Statistiek (CBS). Om de robuustheid van de informatie te vergroten, hebben de gepresenteerde gegevens telkens betrekking op het gemiddelde van de jaren 1995 en 1996. Om de herkenbaarheid van individuele respondenten te voorkomen, heeft het CBS de restrictie gesteld dat bij het publiceren van tweejaarlijkse gemiddelden alleen cijfers over categorieën mogen worden gepresenteerd die betrekking hebben op minimaal 2.500 personen.

Voor alle drie de invalshoeken (bedrijf, beroep en opleiding) zijn de gebruikte classificaties vernieuwd. Bij de informatie naar bedrijfssector (deel 1), waarbij de classificatie is gebaseerd op de Standaard Bedrijfsindeling 1993 (SBl'93) van het CBS, is het aantal bedrijfssectoren uitgebreid van 13 tot 35 . Bij de informatie naar beroepsgroep (deel 2), waarbij de classificatie voor het eerst is gebaseerd op de Standaard Beroepsclassificatie 1992 (SBC'92) van het CBS, is het aantal beroepen uitgebreid van 93 tot 127 . Hierbij is de 3-digitcode van het CBS gebruikt, waarbij de code 471 is uitgesplitst in Bakkers en Slagers en Procesoperators. Bovendien is bij de elementaire beroepen een uitsplitsing gemaakt naar zes beroepsgroepen. Tevens is 
afgeweken van de door het CBS gehanteerde namen. In plaats daarvan worden kortere beroepsgroepnamen gebruikt. Bij de informatie naar opleiding (deel 3 ) is het aantal opleidingstypen uitgebreid van 79 tot 104 . Ook de opleidingsindeling is nieuw.

De in het derde deel gepresenteerde schoolverlatersinformatie is afkomstig uit de grootschalige schoolverlatersenquêtes Registratie Uitstroom en Bestemming van Schoolverlaters (RUBS), de HBO-Monitor' en WO-economie. In deze onderzoeken worden de schoolverlaters anderhalf jaar na het verlaten van de opleiding geënquêteerd. De in deze versie van de Statistische Bijlage gepresenteerde informatie heeft betrekking op de arbeidsmarktsituatie in 1996 van de gediplomeerden uit het leerjaar 1994-1995. Aan het presenteren van deze schoolverlatersinformatie is de restrictie gesteld dat de gepubliceerde informatie per categorie minimaal betrekking moet hebben op 15 schoolverlaters.

De opleidingsindeling die gehanteerd wordt voor de schoolverlatersinformatie is voor het eerst zowel voor de opleidingen tot en met MBO-niveau als de opleidingen op HBO-niveau gebaseerd op de SOl-5-digitcode van het CBS en ingedeeld conform de opleidingsindeling die wordt gehanteerd voor de actuele arbeidsmarktinformatie. Er zijn twee grote verschillen tussen de opleidingstypen die onderscheiden worden bij schoolverlatersinformatie en de opleidingstypen die onderscheiden worden bij de overige arbeidsmarktinfomratie:

- op MBO-niveau omvatten de opleidingen bij de schoolverlatersgegevens geen leerlingwezenopleidingen;

- op MBO-niveau worden voor zover mogelijk de opleidingen bij de schoolverlatersgegevens uitgesplitst in MBO- en KMBO-opleidingen.

Wanneer niet voldaan wordt aan de ondergrens voor publicatie of wanneer het gegeven onbekend is, wordt dit in de tabellen met arbeidsmarktgegevens aangegeven met een -.

Achterin het hoofdrapport worden de gehanteerde centrale begrippen gedefinieerd, waarbij telkens verwezen wordt naar de publicaties waarin nadere informatie te vinden is. In een apart te publiceren werkdocument zal een overzicht worden gegeven van de onderscheiden bedrijfssectoren, beroepsgroepen en opleidingstypen met bijbehorende coderingen.

1. De opleidingsindeling die gehanteerd wordt voor de HBO-opleidingsrichtingen is enigzins afwijkend van de tabellen in de publicaties van de HBO-Monitor. 


\section{Toelichting bij gebruik}

In deze Statistische Bijlage bij de Arbeidsmarkt naar opleiding en beroep tot 2002 wordt een overzicht gegeven van de bijeengebrachte informatie die een beeld geeft van de arbeidsmarktsituatie van achtereenvolgens bedrijfssectoren, beroepsgroepen en opleidingstypen. Deze gegevens hebben tot doel de aansluiting tussen onderwijs en arbeidsmarkt transparant te maken. Dit kan een ondersteuning betekenen voor degenen die betrokken zijn bij beslissingen rondom het onderwijs. Hierbij kan gedacht worden aan leerlingen die voor hun studiekeuze staan, de overheid, de arbeidsvoorzieningsorganisatie, scholen maar ook degenen die in het bedrijfsleven betrokken zijn bij het wervingsbeleid.

Om inzicht te geven in de aansluiting tussen onderwijs en arbeidsmarkt wordt een drietal soorten gegevens gepresenteerd. Dit zijn achtereenvolgens de actuele arbeidsmarktsituatie, de structurele positie van beroepen en opleidingen, de prognoses tot het jaar 2002.

De prognoses hebben betrekking op de middellange termijn, in dit rapport tot het jaar 2002 . Omdat veel (beroeps)opleidingen in Nederland een duur hebben van vier jaar is het van belang om te anticiperen op de ontwikkelingen op de arbeidsmarkt over vijf jaar. Hierdoor kan een eventuele omslag in de arbeidsmarktpositie tijdig worden voorzien. De prognoses zijn opgesteld uit een vergelijking van vraag en aanbod van nieuwkomers op de arbeidsmarkt. Aan de vraagkant betreft dit de uitbreidingsvraag en de vervangingsvraag die tezamen de baanopeningen vormen. Aan de aanbodkant gaat het in de eerste plaats om de arbeidsmarktintroom van schoolverlaters. De Indicator Toekomstige Arbeidsmarktperspectieven (ITA) geeft de verhouding tussen vraag en aanbod weer. Hierbij is tevens rekening gehouden met het aanbod van kortdurige werklozen en zijn ook de effecten verdisconteerd die het gevolg zijn vraagoverschotten of -tekorten bij concurrerende opleidingstypen. ${ }^{2}$ Daarbij moet worden bedacht dat een aanbodoverschot van mensen met een bepaalde opleidingsachtergrond niet per se tot werkloosheid van de betrokkenen hoeft te leiden. Veelal uiten discrepanties tussen vraag en aanbod zich in een hogere kans op werk buiten het eigen vakgebied, of beneden het gevolgde opleidingsniveau, een lagere beloning, meer kans op een tijdelijk contract, enz.

Bij de actuele arbeidsmarktinformatie wordt tevens een indicatie van de trend gegeven. Deze trend weerspiegelt de veranderingen in de betreffende grootheid in de afgelopen periode en heeft op zich geen voorspellende betekenis. Hoewel de actuele situatie af kan wijken van de ontwikkelingen tot 2002 is het van belang de voorspelde arbeidsmarktperspectieven te bezien in het licht van de actuele arbeidsmarktsituatie. Met name tussen de verschillende opleidingsniveaus bestaan er immers aanzienlijke structurele verschillen in de arbeidsmarktpositie die door tegengestelde arbeidsmarktperspectieven niet geheel zullen worden weggenomen. Zo zal een WO-afgestudeerde die een richting volgt met slechte perspectieven mogelijk een functie krijgen met een minder gunstige beloning, maar dan toch kan deze beloning hoger liggen dan van VBO'ers uit richtingen met een gunstig perspectief.

Om deze reden wordt naast de prognoses informatie verstrekt over de actuele situatie op de

2. In De arbeidsmarkt naar opleiding en beroep tot 2002 wordt in figuur 1.1 de globale opzet van het prognosemodel in beeld gebracht. 
arbeidsmarkt. Deze 'monitoring' die deels is gebaseerd op enquêtes onder schoolverlaters brengt daarnaast kenmerken aan het licht die niet rechtstreeks gekoppeld kunnen worden aan het arbeidsmarktperspectief en wellicht door verschillende betrokkenen anders zullen worden gewaardeerd. Voorbeelden hiervan zijn de beroepenspreiding van de werkenden met een bepaalde opleidingsachtergrond, maar ook het percentage deeltijdwerk.

Als derde categorie is informatie opgenomen over de structurele positie van beroepsgroepen en opleidingstypen. Het betreft hier de conjunctuurgevoeligheid van de werkgelegenheid, de uitwijk- en substitutiemogelijkheden en de concurrentie-index. Deze indicatoren hebben tot doel het geschetste perspectief in een breder kader te plaatsen. De prognoses van vraag en aanbod zijn uiteraard altijd aan onzekerheid onderhevig. Bovendien zal een schoolverlater doorgaans een lange tijd op de arbeidsmarkt vertoeven. De structurele kenmerken beogen daarom een indicatie te geven van de het risico dat men op de arbeidsmarkt loopt. Zo geeft de conjunctuurgevoeligheid aan in welke mate de werkgelegenheid in het desbetreffende segment aan schommelingen onderhevig is, terwijl de uitwijkmogelijkheden aangeven in welke mate werkenden afhankelijk zijn van de werkgelegenheidsontwikkelingen in één beroep of bedrijfssector of juist uit kunnen wijken naar meerdere beroepen en bedrijfssectoren. Verder geeft de concurrentie-index aan welke opleidingstypen een overlappend deel van de arbeidsmarkt bestrijken. Hierdoor ontstaat een beeld van de concurrerende opleidingstypen.

Zoals reeds is opgemerkt bevat de Statistische bijlage informatie over bedrijfsectoren, beroepsgroepen en opleidingstypen. De confrontatie tussen vraag en aanbod vindt plaats op het niveau van opleidingstypen, omdat in eerste instantie de opleidingsachtergrond van werkenden de afbakening van deelmarkten op de arbeidsmarkt bepaalt. De prognoses met betrekking tot de onderscheiden bedrijfssectoren en beroepsgroepen hebben daarom alleen betrekking op de vraagkant van de arbeidsmarkt. Men dient zich daarbij te realiseren dat een groot aantal baanopeningen niet altijd een gunstig perspectief hoeft in te houden, omdat ook in dat geval de aanbodontwikkeling nog omvangrijker kan zijn. 
1 INFORMATIE OVER BEDRIJVEN 
Tabel 1.1

Aantal werkenden per bedrijfssector, gemiddelde 1995-1996

\begin{tabular}{|c|c|c|c|}
\hline Bedrijfssector & aantal werkenden & $\begin{array}{l}\text { trend } \\
\text { 1994-'96 }\end{array}$ & arbeidsvolume \\
\hline Tuinbouw & 74.500 & sterk stijgend & 77.000 \\
\hline Veehouderij & 128.500 & constant & 158.000 \\
\hline Akkerbouw, bosbouw en visserij & 25.000 & sterk dalend & 30.000 \\
\hline Vlees- en visverwerking & 33.000 & stijgend & 31.000 \\
\hline Overige voedingsproducten & 108.500 & constant & 100.500 \\
\hline Drank en tabaksproducten & 16.500 & - & 15.500 \\
\hline Basischemie & 44.500 & constant & 42.500 \\
\hline Eindproducten chemie & 47.000 & constant & 43.500 \\
\hline Kunststofverwerking & 39.000 & constant & 37.500 \\
\hline Basismetaal & 29.500 & dalend & 28.000 \\
\hline Metaalproducten & 223.000 & constant & 213.000 \\
\hline Machine-industrie & 91.000 & sterk stijgend & 89.000 \\
\hline Elektrotechniek & 108.500 & constant & 104.000 \\
\hline Transportmiddelen & 57.500 & constant & 57.000 \\
\hline Textiel & 34.500 & dalend & 31.500 \\
\hline Hout- en bouwmaterialen & 54.500 & constant & 53.500 \\
\hline Papier & 26.000 & constant & 24.000 \\
\hline Grafische industrie & 94.500 & constant & 85.000 \\
\hline Energie & 61.500 & dalend & 58.500 \\
\hline Bouw & 410.000 & constant & 412.000 \\
\hline Exploitatie van onroerend goed & 45.500 & constant & 41.500 \\
\hline Handel & 865.000 & stijgend & 801.000 \\
\hline Scheeps- en luchtvaart & 44.500 & constant & 44.000 \\
\hline Weg-en railvervoer & 249.000 & constant & 246.000 \\
\hline Communicatie & 91.500 & constant & 80.500 \\
\hline Bankwezen & 136.000 & constant & 122.500 \\
\hline Verzekeringswezen & 87.500 & stijgend & 83.000 \\
\hline Horeca & 165.000 & constant & 152.500 \\
\hline Reparatie & 86.500 & constant & 88.500 \\
\hline Zakelijke dienstverlening & 543.000 & stijgend & 510.500 \\
\hline Overige commerciële dienstverlening & 95.000 & stijgend & 80.500 \\
\hline Gezondheidszorg & 810.500 & stijgend & 618.500 \\
\hline Overige kwartaire diensten & 172.000 & constant & 153.000 \\
\hline Onderwijs & 408.000 & constant & 349.500 \\
\hline Overheid & 499.000 & constant & 458.000 \\
\hline Totaal & 6115.000 & & 5623.000 \\
\hline
\end{tabular}

Bron: CBS/ROA

Toelichting:

Het aantal werkenden heeft betrekking op iedereen die jonger is dan 65 en minstens 12 uur per week werkt. Arbeidsvolume is het totaal aantal normaal gewerkte arbeidsuren gedeeld door 40 . 
Tabel 1.2

Percentage vrouwen per bedrijfssector, gemiddelde 1995-1996

\begin{tabular}{|c|c|c|c|}
\hline Bedrijfssector & $\%$ & typering & $\begin{array}{l}\text { trend } \\
1994-' 96\end{array}$ \\
\hline Tuinbouw & 31 & gemiddeld & constant \\
\hline Veehouderij & 18 & gemiddeld & constant \\
\hline Akkerbouw, bosbouw en visserij & 19 & gemiddeld & sterk dalend \\
\hline Vlees- en visverwerking & 28 & gemiddeld & - \\
\hline Overige voedingsproducten & 30 & gemiddeld & constant \\
\hline Drank en tabaksproducten & 14 & gemiddeld & sterk stijgend \\
\hline Basischemie & 10 & laag & sterk dalend \\
\hline Eindproducten chemie & 27 & gemiddeld & sterk stijgend \\
\hline Kunststofverwerking & 15 & gemiddeld & constant \\
\hline Basismetaal & 8 & laag & sterk stijgend \\
\hline Metaalproducten & 15 & gemiddeld & constant \\
\hline Machine-industrie & 10 & laag & sterk stijgend \\
\hline Elektrotechniek & 21 & gemiddeld & constant \\
\hline Transportmiddelen & 7 & laag & sterk dalend \\
\hline Textiel & 41 & gemiddeld & - \\
\hline Hout- en bouwmaterialen & 10 & laag & constant \\
\hline Papier & 17 & gemiddeld & sterk stijgend \\
\hline Grafische industrie & 31 & gemiddeld & constant \\
\hline Energie & 15 & gemiddeld & sterk stijgend \\
\hline Bouw & 6 & laag & dalend \\
\hline Exploitatie van onroerend goed & 39 & gemiddeld & constant \\
\hline Handel & 42 & gemiddeld & constant \\
\hline Scheeps-en luchtvaart & 28 & gemiddeld & - \\
\hline Weg- en railvervoer & 18 & gemiddeld & constant \\
\hline Communicatie & 27 & gemiddeld & constant \\
\hline Bankwezen & 44 & gemiddeld & constant \\
\hline Verzekeringswezen & 38 & gemiddeld & constant \\
\hline Horeca & 48 & gemiddeld & constant \\
\hline Reparatie & 12 & gemiddeld & stijgend \\
\hline Zakelijke dienstverlening & 37 & gemiddeld & constant \\
\hline Overige commerciële dienstverlening & 59 & hoog & dalend \\
\hline Gezondheidszorg & 77 & hoog & constant \\
\hline Overige kwartaire diensten & 42 & gemiddeld & dalend \\
\hline Onderwijs & 49 & gemiddeld & constant \\
\hline Overheid & 30 & gemiddeld & constant \\
\hline Totaal & 37 & gemiddeld & \\
\hline
\end{tabular}

Bron: CBS/ROA 
Tabel 1.3

Percentage allochtonen per bedrijfssector, gemiddelde 1995-1996

\begin{tabular}{|c|c|c|c|}
\hline Bedrijfssector & $\%$ & typering & $\begin{array}{l}\text { trend } \\
1994-^{\prime} 96\end{array}$ \\
\hline Tuinbouw & 5 & hoog & - \\
\hline Veehouderij & - & laag & sterk stijgend \\
\hline Akkerbouw, bosbouw en visserij & - & erg laag & - \\
\hline Vlees-en visverwerking & 9 & erg hoog & sterk dalend \\
\hline Overige voedingsproducten & 6 & erg hoog & constant \\
\hline Drank en tabaksproducten & - & hoog & sterk dalend \\
\hline Basischemie & - & gemiddeld & sterk stijgend \\
\hline Eindproducten chemie & - & hoog & sterk dalend \\
\hline Kunststofverwerking & 7 & erg hoog & sterk stijgend \\
\hline Basismetaal & 8 & erg hoog & sterk dalend \\
\hline Metaalproducten & 6 & erg hoog & - \\
\hline Machine-industrie & 3 & gemiddeld & - \\
\hline Elektrotechniek & 3 & gemiddeld & - \\
\hline Transportmiddelen & 6 & erg hoog & sterk dalend \\
\hline Textiel & 8 & erg hoog & - \\
\hline Hout- en bouwmaterialen & 5 & hoog & sterk stijgend \\
\hline Papier & - & erg hoog & constant \\
\hline Grafische industrie & 3 & gemiddeld & - \\
\hline Energie & - & gemiddeld & sterk dalend \\
\hline Bouw & 2 & gemiddeld & sterk dalend \\
\hline Exploitatie van onroerend goed & - & laag & sterk dalend \\
\hline Handel & 3 & gemiddeld & constant \\
\hline Scheeps- en luchtvaart & 6 & erg hoog & - \\
\hline Weg-en railvervoer & 3 & gemiddeld & - \\
\hline Communicatie & 5 & hoog & sterk stijgend \\
\hline Bankwezen & 4 & hoog & - \\
\hline Verzekeringswezen & - & gemiddeld & sterk dalend \\
\hline Horeca & 6 & erg hoog & - \\
\hline Reparatie & 4 & hoog & constant \\
\hline Zakelijke dienstverlening & 4 & hoog & sterk stijgend \\
\hline Overige commerciële dienstverlening & 4 & hoog & stijgend \\
\hline Gezondheidszorg & 3 & gemiddeld & sterk stijgend \\
\hline Overige kwartaire diensten & 2 & gemiddeld & - \\
\hline Onderwijs & 2 & gemiddeld & stijgend \\
\hline Overheid & 3 & gemiddeld & - \\
\hline Totaal & 3 & gemiddeld & \\
\hline
\end{tabular}

\section{Bron: CBS/ROA}

Toelichting:

Het percentage allochtonen heeft betrekking op iedereen die een niet-Nederlandse nationaliteit bezit, of die buiten Nederland is geboren, in één van de landen die genoemd worden in de Wet Bevordering Evenredige Arbeidsdeelname Allochtonen (WBEAA). Deze landen zijn: Aruba, Nederlandse Antillen, Ethiopië, Irak, Iran, voormalige Joegoslavië, Marokko, Somalië, Suriname, Turkijke en Vietnam. Op grond van deze wet zouden echter ook kinderen van allochtonen tot de doelgroep gerekend moeten worden, ongeacht of zij een nietNederlandse nationaliteit bezitten. 
Tabel 1.4

Percentage jongeren (15-29 jaar) en ouderen (50-64 jaar) per bedrijfssector, gemiddelde 1995-1996

\begin{tabular}{rrlrr}
\hline Bedrijfssector & $\%$ & trend & $\%$ & trend \\
& jongeren & $1994-96$ & ouderen & $1994-96$
\end{tabular}

Tuinbouw
Veehouderij
Akkerbouw, bosbouw en visserij
Vlees- en visverwerking
Overige voedingsproducten
Drank en tabaksproducten
Basischemie
Eindproducten chemie
Kunststofverwerking
Basismetaal
Metaalproducten
Machine-industrie
Elektrotechniek
Transportmiddelen
Textiel
Hout- en bouwmaterialen
Papier
Grafische industrie
Energie
Bouw
Exploitatie van onroerend goed
Handel
Scheeps- en luchtvaart
Weg- en railvervoer
Communicatie
Bankwezen
Verzekeringswezen
Horeca
Reparatie
Zakelijke dienstverlening
Overige commerciële dienstverlening
Gezondheidszorg
Overige kwartaire diensten
Onderwijs
Overheid

Totaal

$\begin{array}{ll}39 & \text { constant } \\ 26 & \text { constant } \\ 20 & \text { sterk dalend } \\ 44 & \text { constant } \\ 33 & \text { constant } \\ 20 & \text { stijgend } \\ 17 & \text { sterk dalend } \\ 25 & \text { - } \\ 29 & \text { constant } \\ 19 & \text { - } \\ 26 & \text { constant } \\ 30 & \text { constant } \\ 27 & \text { dalend } \\ 30 & \text { sterk stijgend } \\ 31 & \text { constant } \\ 31 & \text { - } \\ 26 & \text { constant } \\ 29 & \text { dalend } \\ 15 & \text { constant } \\ 32 & \text { constant } \\ 22 & \text { sterk dalend } \\ 40 & \text { constant } \\ 30 & \text { constant } \\ 26 & \text { constant } \\ 22 & \text { dalend } \\ 29 & \text { dalend } \\ 28 & \text { dalend } \\ 48 & \text { constant } \\ 36 & - \\ 32 & \text { constant } \\ 36 & \text { dalend } \\ 25 & \text { dalend } \\ 22 & \text { dalend } \\ 13 & \text { dalend } \\ 18 & \text { - } \\ & \end{array}$

$19-$

29 constant

29 sterk stijgend

8 sterk dalend

14 dalend

17 sterk dalend

22 .

18 constant

14 sterk stijgend

20 sterk stijgend

17 constant

15 sterk stijgend

14 .

15 sterk stijgend

20 -

17 constant

14 constant

15 stijgend

20 -

15 -

19 .

13 constant

11 constant

15 stijgend

13 -

10 dalend

13 sterk dalend

9 stijgend

14 sterk stijgend

12 constant

14 stijgend

12 stijgend

17 stijgend

23 stijgend

16 sterk stijgend

Bron: CBS/ROA 


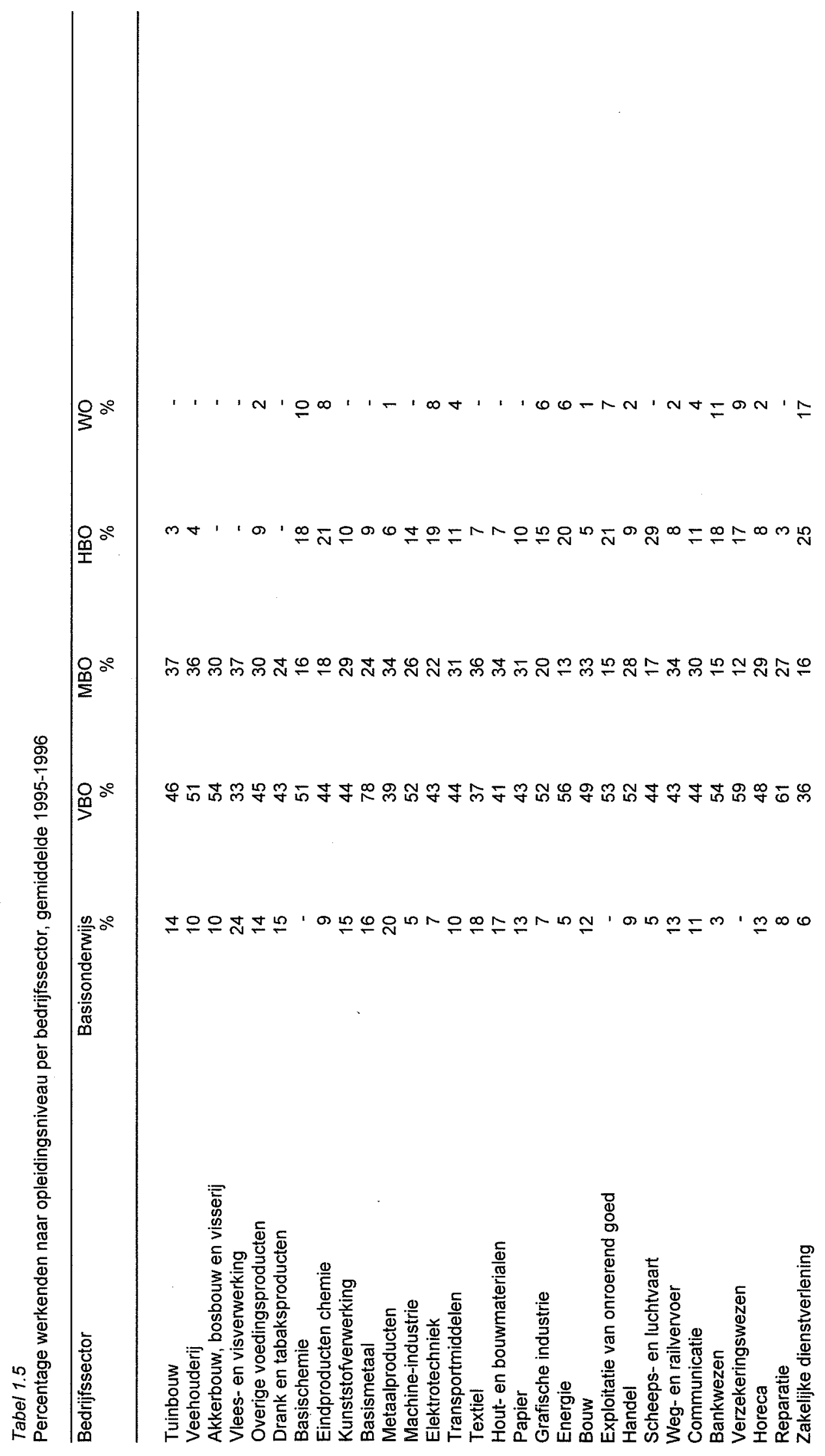




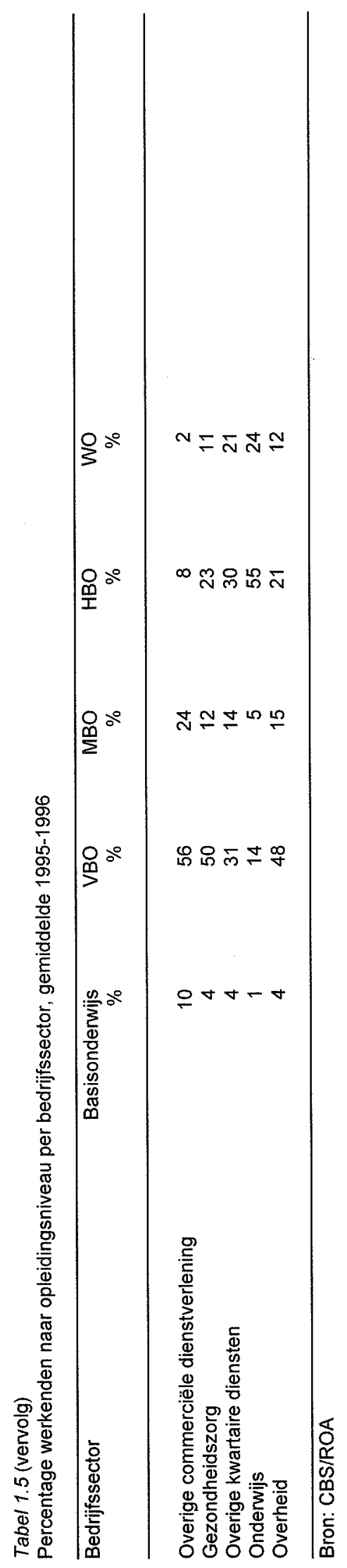


Tabel 1.6

Deeltijdarbeid per bedrijfssector, gemiddelde 1995-1996

\begin{tabular}{llll}
\hline Bedrijfssector & $\%$ & $\begin{array}{l}\text { trend } \\
1994-96\end{array}$ & $\begin{array}{l}\text { gemiddeld aantal } \\
\text { uren per week }\end{array}$
\end{tabular}

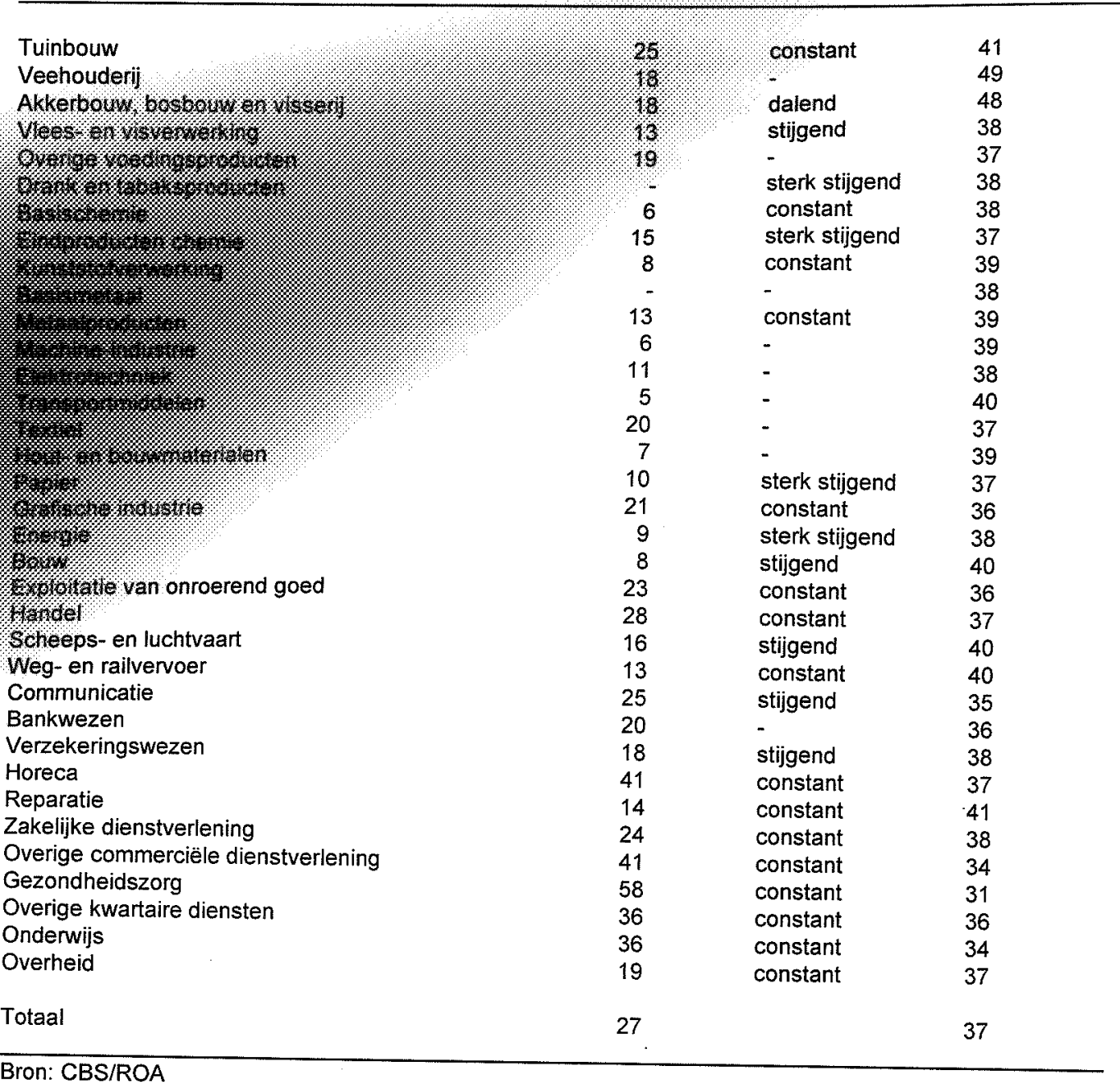

\section{Toelichting:}

Deeltijdarbeid betreft personen die hoogstens 32 uur maar minstens 12 uur per week werkzaam zijn. 
Tabel 1.7

Flexibel en vast werk per bedrijfssector, gemiddelde 1995-1996

\begin{tabular}{|c|c|c|c|c|}
\hline Bedrijfssector & $\begin{array}{r}\% \text { flexibel } \\
\text { werk }\end{array}$ & $\begin{array}{l}\text { trend } \\
1994-' 96\end{array}$ & $\begin{array}{l}\text { \% vast } \\
\text { werk }\end{array}$ & $\begin{array}{l}\text { trend } \\
1994-96\end{array}$ \\
\hline Tuinbouw & 15 & stijgend & 74 & - \\
\hline Veehouderij & 5 & constant & 85 & stijgend \\
\hline Akkerbouw, bosbouw en visserij & - & sterk dalend & 71 & sterk dalend \\
\hline Vlees- en visverwerking & 18 & constant & 83 & constant \\
\hline Overige voedingsproducten & 9 & sterk stijgend & 90 & constant \\
\hline Drank en tabaksproducten & - & - & 94 & constant \\
\hline Basischemie & - & sterk stijgend & 96 & constant \\
\hline Eindproducten chemie & 6 & stijgend & 94 & constant \\
\hline Kunststofverwerking & 7 & sterk stijgend & 93 & constant \\
\hline Basismetaal & - & sterk stijgend & 95 & constant \\
\hline Metaalproducten & 7 & sterk stijgend & 93 & constant \\
\hline Machine-industrie & 5 & sterk stijgend & 94 & constant \\
\hline Elektrotechniek & 7 & sterk stijgend & 93 & constant \\
\hline Transportmiddelen & 9 & sterk stijgend & 91 & constant \\
\hline Textiel & 8 & - & 90 & constant \\
\hline Hout- en bouwmaterialen & 8 & sterk stijgend & 92 & constant \\
\hline Papier & - & sterk stijgend & 92 & constant \\
\hline Grafische industrie & 8 & - & 91 & constant \\
\hline Energie & 4 & sterk stijgend & 95 & constant \\
\hline Bouw & 5 & sterk stijgend & 95 & constant \\
\hline Exploitatie van onroerend goed & - & - & 95 & dalend \\
\hline Handel & 8 & stijgend & 91 & constant \\
\hline Scheeps-en luchtvaart & 8 & sterk stijgend & 93 & dalend \\
\hline Weg-en railvervoer & 7 & sterk stijgend & 92 & constant \\
\hline Communicatie & 9 & sterk stijgend & 91 & constant \\
\hline Bankwezen & 5 & sterk stijgend & 95 & constant \\
\hline Verzekeringswezen & 5 & sterk stijgend & 94 & dalend \\
\hline Horeca & 21 & sterk stijgend & 74 & constant \\
\hline Reparatie & 4 & sterk stijgend & 95 & dalend \\
\hline Zakelijke dienstverlening & 9 & sterk stijgend & 89 & constant \\
\hline Overige commerciële dienstverlening & 10 & constant & 84 & constant \\
\hline Gezondheidszorg & 9 & sterk stijgend & 90 & constant \\
\hline Overige kwartaire diensten & 11 & - & 87 & constant \\
\hline Onderwijs & 6 & constant & 93 & constant \\
\hline Overheid & 5 & sterk stijgend & 95 & constant \\
\hline Totaal & 8 & & 91 & \\
\hline
\end{tabular}

\section{Bron: CBS/ROA}

\section{Toelichting:}

Van een flexibele arbeidsrelatie is sprake bij uitzendkrachten, oproepkrachten, invalskrachten en contracten zonder een vast aantal arbeidsuren en indien geen vast dienstverband is overeengekomen. Een arbeidscontract wordt als niet-vast beschouwd als de contractuele termijn korter is dan een jaar en er geen vooruitzicht is op een vast dienstverband. 
Tabel 1.8

Zelfstandigen per bedrijfssector, gemiddelde 1995-1996

Bedrijfssector

$\begin{array}{lll}\% & \text { typering } & \text { trend } \\ & 1994-' 96\end{array}$

Tuinbouw

\begin{tabular}{|c|c|c|}
\hline 40 & erg hoog & - \\
\hline 69 & erg hoog & dalend \\
\hline 73 & erg hoog & sterk stijgend \\
\hline - & erg laag & sterk dalend \\
\hline 6 & laag & constant \\
\hline - & erg laag & - \\
\hline- & erg laag & - \\
\hline- & erg laag & sterk stijgend \\
\hline - & erg laag & sterk stijgend \\
\hline- & erg laag & - \\
\hline 6 & laag & stijgend \\
\hline 3 & erg laag & constant \\
\hline 2 & erg laag & - \\
\hline- & erg laag & constant \\
\hline 11 & gemiddeld & stijgend \\
\hline 5 & laag & sterk stijgend \\
\hline- & erg laag & - \\
\hline 8 & gemiddeld & sterk stijgend \\
\hline- & erg laag & - \\
\hline 13 & hoog & constant \\
\hline 13 & hoog & sterk stijgend \\
\hline 15 & hoog & dalend \\
\hline- & erg laag & constant \\
\hline 7 & gemiddeld & constant \\
\hline- & erg laag & sterk stijgend \\
\hline 2 & erg laag & - \\
\hline 9 & gemiddeld & sterk stijgend \\
\hline 22 & hoog & constant \\
\hline 21 & hoog & sterk stijgend \\
\hline 17 & hoog & constant \\
\hline 32 & erg hoog & constant \\
\hline 6 & laag & constant \\
\hline 19 & hoog & dalend \\
\hline 3 & erg laag & - \\
\hline 1 & erg laag & constant \\
\hline 12 & gemiddeld & \\
\hline
\end{tabular}

Veehouderij

Akkerbouw, bosbouw en visserij

Vlees- en visverwerking

Overige voedingsproducten

Drank en tabaksproducten

Basischemie

Eindproducten chemie

Kunststofverwerking

Basismetaal

Metaalproducten

Machine-industrie

Elektrotechniek

Transportmiddelen

Textiel

Hout- en bouwmaterialen

Papier

Grafische industrie

Energie

Bouw

Exploitatie van onroerend goed

Handel

Scheeps- en luchtvaart

Weg-en railvervoer

Communicatie

Bankwezen

Verzekeringswezen

Horeca

Reparatie

Zakelijke dienstverlening

Overige commerciële dienstverlening

Gezondheidszorg

Overige kwartaire diensten

Onderwijs

Overheid

Totaal

\section{Bron: CBS/ROA}

\section{Toelichting:}

Het begrip zelfstandig bevat ook personen die werkzaam zijn in het bedriif of de praktijk van hun partner of ouders en freelancers e.d. 
Tabel 1.9

Belangrijkste beroepsgroepen per bedrijfssector, gemiddelde 1995-1996

\begin{tabular}{lll}
\hline Bedrifssector & $\%$ & trend \\
& & $1994-96$
\end{tabular}

\section{Tuinbouw}

Agrarische arbeiders

Agrarische bedrijfshoofden

Agrarische hulparbeiders

Andere beroepsgroepen

\section{Veehouderij}

Agrarische bedrijfshoofden

Agrarische arbeiders

Andere beroepsgroepen

\section{Akkerbouw, bosbouw en visserij}

Agrarische bedrijfshoofden

Agrarische arbeiders

Landbouwmachinebestuurders en vissers

Andere beroepsgroepen

\section{Vlees- en visverwerking}

Mechanisch operators

Productiemedewerkers

Kantoorhulpen, inpakkers en colporteurs

Andere beroepsgroepen

\section{Overige voedingsproducten}

Mechanisch operators

Procesoperators

Verkopers

Productiemedewerkers.

Bakkers en slagers

Chauffeurs

Boekhouders en secretaresses

Andere beroepsgroepen

\section{Drank en tabaksproducten}

Mechanisch operators

Andere beroepsgroepen

\section{Basischemie}

Procesoperators

Mechanisch operators

Monteurs

Andere beroepsgroepen
44

stijgend

dalend

sterk stijgend

$$
\text { - }
$$

constant

stijgend

constant

constant

sterk stijgend

-

sterk stijgend

dalend

dalend

sterk dalend

dalend

dalend

sterk stijgend

-

sterk stijgend

-

sterk stijgend

dalend

dalend 
Tabel 1.9 (vervolg)

Belangrijkste beroepsgroepen per bedrijfssector, gemiddelde 1995-1996

\begin{tabular}{lll}
\hline Bedrijfssector & $\%$ & trend \\
& & $1994-' 96$
\end{tabular}

\section{Eindproducten chemie}

Boekhouders en secretaresses

sterk stijgend

Mechanisch operators

Procesoperators

sterk stijgend

Productiemedewerkers

constant

Commercieel employés

constant

Andere beroepsgroepen

\section{Kunststofverwerking}

Mechanisch operators

Procesoperators

Monteurs

Andere beroepsgroepen

\section{Basismetaal}

Metaalarbeiders

Bankwerkers en lassers

Monteurs

Andere beroepsgroepen

\section{Metaalproducten}

Metaalarbeiders

Bankwerkers en lassers

Aannemers en installateurs

Agrarische arbeiders

Andere beroepsgroepen

\section{Machine-industrie}

Monteurs

Metaalarbeiders

Bankwerkers en lassers

Boekhouders en secretaresses

Werktuigbouwkundig ontwerpers en hoofden technische dienst 5

Andere beroepsgroepen

sterk stijgend dalend sterk dalend

\section{Elektrotechniek}

Productiemedewerkers

Elektromonteurs

Boekhouders en secretaresses

-

Andere beroepsgroepen

sterk stijgend

stijgend

sterk dalend

stijgend

-

dalend

stijgend

constant

stijgend

constant

$$
-
$$

dalend

stijgend

constant

\section{Transportmiddelen}

Monteurs

Metaalarbeiders

Bankwerkers en lassers

Assembleurs

Boekhouders en secretaresses

stijgend

constant

dalend

stijgend

sterk stijgend 


\begin{tabular}{lll}
\hline Bedrijfssector & $\%$ & trend \\
& & $1994-96$
\end{tabular}

\section{Textiel}

Confectie-arbeiders

Mechanisch operators

Schoen- en kleermakers

Andere beroepsgroepen

Hout- en bouwmaterialen

Bouwvakkers

Aannemers en instaliateurs

Monteurs

Chauffeurs

Mechanisch operators

Productiemedewerkers

Andere beroepsgroepen

\section{Papier}

Grafisch productiepersoneel

Procesoperators

Andere beroepsgroepen

\section{Grafische industrie}

Grafische vakkrachten

Grafisch productiepersoneel

Journalisten

Commercieel employés

Boekhouders en secretaresses

Andere beroepsgroepen

\section{Energie}

Elektromonteurs

Boekhouders en secretaresses

Monteurs

Receptionisten en administratieve employés

Aannemers en installateurs

Andere beroepsgroepen

Bouw

Bouwvakkers

Aannemers en installateurs

Elektromonteurs

Andere beroepsgroepen

\section{Exploitatie van onroerend goed}

Boekhouders en secretaresses

Receptionisten en administratieve employés

Commercieel employés

Aannemers en installateurs

Commercieel medewerkers

Andere beroepsgroepen constant sterk dalend sterk stijgend

$$
\text { - }
$$

constant constant sterk stijgend sterk dalend stijgend sterk dalend

-

constant dalend -

constant dalend sterk stijgend dalend sterk stijgend -

constant stijgend dalend dalend constant constant constant stijgend 
Tabel 1.9 (vervolg)

Belangrijkste beroepsgroepen per bedrijfssector, gemiddelde 1995-1996

Bedrijfssector

$\%$

trend

1994-'96

\section{Handel}

Verkopers
Winkeliers
Commercieel medewerkers
Commercieel employés
Boekhouders en secretaresses
Andere beroepsgroepen

Andere beroepsgroepen

stijgend

\section{Scheeps- en luchtvaart}

Vliegers, scheepskapiteins en leidinggevenden transport

Schippers en conducteurs

Monteurs

Boekhouders en secretaresses

Andere beroepsgroepen
Stewards

Weg-en railvervoer

\section{Chauffeurs}

Commercieel employés

Monteurs

Boekhouders en secretaresses

Administratieve transportemployés

Andere beroepsgroepen

\section{Communicatie}

Chauffeurs

Receptionisten en administratieve employés

Commercieel employés

Elektromonteurs

Productiemedewerkers

Boekhouders en secretaresses

Andere beroepsgroepen

\section{Bankwezen}

Commercieel employés

Commercieel medewerkers

Boekhouders en secretaresses

Receptionisten en administratieve employés

Andere beroepsgroepen

stijgend constant sterk stijgend stijgend stijgend

constant stijgend dalend stijgend sterk stijgend -

constant stijgend constant stijgend sterk stijgend sterk dalend

\section{Verzekeringswezen}

Commercieel employés

Receptionisten en administratieve employés

constant stijgend sterk stijgend dalend

Verzekeringsagenten

Boekhouders en secretaresses

Commercieel medewerkers

Andere beroepsgroepen sterk dalend 
$\%$ trend

1994-'96

\section{Horeca}

Hulpkrachten horeca en verzorging $\quad 30$

Interieurverzorgers

Bedrijfshoofden horeca

Verzorgend personeel

Café- en snackbarhouders

Andere beroepsgroepen

\section{8}

17

11

6

17 stijgend

sterk stijgend

dalend

constant

constant

\section{Reparatie}

Monteurs

Boekhouders en secretaresses

Metaalarbeiders

Verkopers

Receptionisten en administratieve employés

Andere beroepsgroepen
46

\section{Zakelijke dienstverlening}

Boekhouders en secretaresses

Interieurverzorgers

Assistent accountants

Systeemanalisten

Andere beroepsgroepen

11

8

6

6

70

\section{Overige commerciële dienstverlening}

Verzorgend personeel

Hulpkrachten horeca en verzorging

Chauffeurs

Andere beroepsgroepen

\section{Gezondheidszorg}

Verzorgend personeel

Verplegenden en doktersassistenten

Therapeuten en verpleegkundigen

Hulpkrachten horeca en verzorging

Ziekenverzorgenden

Artsen

Andere beroepsgroepen
36

9

6

49 dalend constant stijgend stijgend dalend

stijgend constant dalend stijgend

dalend sterk dalend sterk stijgend -

dalend constant stijgend constant stijgend constant -

constant sterk stijgend

Boekhouders en secretaresses

\section{Onderwijs}

Lefaar basisonderwijs

Docenten talen en expressie

Docenten letteren (1e graads)

Andere beroepsgroepen constant constant constant 
Tabel 1.9 (vervolg)

Belangrijkste beroepsgroepen per bedrijfssector, gemiddelde 1995-1996

\begin{tabular}{lll}
\hline Bedrijfssector & $\%$ & trend
\end{tabular}

1994-'96

\section{Overheid}

Boekhouders en secretaresses

Politieagenten, onderofficieren en beveiligingsemployés

Receptionisten en administratieve employés

Juridisch en fiscaal medewerkers

Andere beroepsgroepen constant

stijgend

sterk dalend

sterk stijgend 
Tabel 1.10

Belangrijkste opleidingstypen per bedrijfssector, gemiddelde 1995-1996

Bedrijfssector $\quad \% \quad$ trend

\section{Tuinbouw}

MBO/LLW landbouw en veeteelt

VBO landbouw en natuurlijke omgeving

Basisonderwijs

MAVO

VBO verzorging

MBO/LLW handel

Andere opleidingstypen

\section{Veehouderij}

MBO/LLW landbouw en veeteelt

VBO landbouw en natuurlijke omgeving

Basisonderwijs

VBO verzorging

Andere opleidingstypen

\section{Akkerbouw, bosbouw en visserij}

MBO/LLW landbouw en veeteelt

VBO landbouw en natuurlijke omgeving

Basisonderwijs

Andere opleidingstypen

\section{Vlees- en visverwerking}

Basisonderwijs

MAVO

Andere opleidingstypen

\section{Overige voedingsproducten}

Basisonderwijs

MBO/LLW brood en banket

MAVO

$\mathrm{MBO} / L \mathrm{LW}$ handel

Andere opleidingstypen

\section{Drank en tabaksproducten}

Basisonderwijs

Andere opleidingstypen

\section{Basischemie}

MBO/LLW procestechniek

WO wiskunde en natuurwetenschappen MAVO

Andere opleidingstypen constant sterk stijgend

$$
\text { - }
$$

dalend constant dalend stijgend sterk dalend sterk stijgend constant constant dalend constant -

sterk stijgend sterk dalend constant dalend sterk dalend constant stijgend -

dalend -

sterk stijgend sterk dalend stijgend 
Tabel 1.10 (vervolg)

Belangrijkste opleidingstypen per bedrijfssector, gemiddelde 1995-1996

\begin{tabular}{lll}
\hline Bedrijfssector & $\%$ & trend \\
& & $1994-96$
\end{tabular}

\section{Eindproducten chemie}

Basisonderwijs

HBO laboratorium

MAVO

MBO/LLW administratie

Andere opleidingstypen

\section{Kunststofverwerking}

Basisonderwijs

MAVO

Andere opleidingstypen

\section{Basismetaal}

Basisonderwijs

MBO/LLW werktuigbouw en mechanische techniek

Andere opleidingstypen

\section{Metaalproducten}

\section{Basisonderwijs}

$\mathrm{MBO/LLW}$ werktuigbouw en mechanische techniek

VBO mechanische techniek

MAVO

VBO bouwtechniek

Andere opleidingstypen

\section{Machine-industrie}

MBO/LLW werktuigbouw en mechanische techniek VBO mechanische techniek

$\mathrm{MBO} / \mathrm{LLW}$ elektrotechniek

HBO werktuigbouwkunde

Basisonderwijs

Andere opleidingstypen

\section{Elektrotechniek}

MBO/LLW elektrotechniek

Basisonderwijs

HBO elektrotechniek

MAVO

MBO/LLW werktuigbouw en mechanische techniek

Andere opleidingstypen

\section{Transportmiddelen}

$\mathrm{MBO} / \mathrm{LLW}$ werktuigbouw en mechanische techniek VBO mechanische techniek

Basisonderwijs

MAVO

Andere opleidingstypen
12 sterk dalend

dalend

constant

constant

-

sterk dalend

constant

-

constant

sterk dalend

-

dalend

stijgend

constant

sterk dalend

dalend

-

dalend

dalend

constant

sterk stijgend

sterk dalend stijgend

constant

constant

dalend

sterk dalend dalend

sterk dalend

dalend

stijgend 
Tabel 1.10 (vervolg)

Belangrijkste opleidingstypen per bedrijfssector, gemiddelde 1995-1996

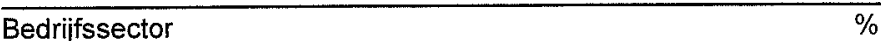

$\%$

trend

1994-'96

\section{Textiel}

Basisonderwijs

constant

MBO/LLW handel

MAVO

VBO verzorging

constant

Andere opleidingstypen

Hout- en bouwmaterialen

Basisonderwijs

MBO/LLW bouw

VBO bouwtechniek

MAVO

Andere opleidingstypen

Papier

Basisonderwijs

Andere opleidingstypen

\section{Grafische industrie}

MBO/LLW grafische techniek

MAVO

HAVONWO

Basisonderwijs

Andere opleidingstypen

\section{Energie}

MBO/LLW elektrotechniek

MBO/LLW werktuigbouw en mechanische techniek

MBO/LLW administratie

Andere opleidingstypen

\section{Bouw}

MBO/LLW bouw

VBO bouwtechniek

Basisonderwijs

MBO/LLW elektrotechniek

Andere opleidingstypen

\section{Exploitatie van onroerend goed}

MBO/LLW administratie

MBO/LLWW bouW

HAVOMWO

MAVO

Andere opleidingstypen constant constant constant

sterk dalend

stijgend

sterk dalend

constant

sterk dalend

constant

dalend

dalend

constant

-

dalend

constant

dalend

stijgend

dalend

sterk dalend

sterk stijgend

sterk dalend 
Tabel 1.10 (vervolg)

Belangrijkste opleidingstypen per bedrijfssector, gemiddelde 1995-1996

\begin{tabular}{lll}
\hline Bedrijfssector & $\%$ & trend \\
& & $1994-96$
\end{tabular}

\section{Handel}

MBO/LLW handel

MAVO

Basisonderwijs

HAVO/NWO

MBO/LLW administratie

VBO verzorging

Andere opleidingstypen

Scheeps- en luchtvaart

HBO vervoer en logistiek

HAVOMWO

MBO/LLW vervoer

MAVO

Basisonderwijs

Andere opleidingstypen

Weg- en railvervoer

Basisonderwijs

MAVO

MBO/LLW vervoer

VBO vervoer

HAVOMWO

Andere opleidingstypen

\section{Communicatie}

Basisonderwijs

MAVO

MBO/LLW elektrotechniek

HAVONWO

MBO/LLW administratie

Andere opleidingstypen

\section{Bankwezen}

\section{HAVONWO}

MBO/LLW administratie

MAVO

MBO/LLW geld, bank en belastingen

Andere opleidingstypen

\section{Verzekeringswezen}

MBO verzekeringswezen

MBO/LLW administratie

HAVONWO

MAVO

Andere opleidingstypen constant

dalend

constant

stijgend

constant

dalend

47

constant

sterk stijgend

dalend

constant

sterk dalend

-

sterk dalend

constant

stijgend

dalend

constant

-

stijgend

constant

constant

stijgend

constant

-

stijgend sterk stijgend

dalend

sterk dalend stijgend

sterk stijgend

dalend

sterk dalend 


\section{Horeca}

MBO/LLW horeca

Basisonderwijs

MAVO

HAVOMWO

VBO verzorging

Andere opleidingstypen

\section{Reparatie}

MBO/LLW motorvoertuigentechniek

MBO/LLW handel

VBO motorvoertuigentechniek

Basisonderwijs

Andere opleidingstypen

\section{Zakelijke dienstverlening}

\author{
HAVO/NWO \\ MBO/LLW administratie \\ MAVO \\ Basisonderwijs \\ Andere opleidingstypen
}

\section{Overige commerciële dienstverlening}

MBO/LLW uiterlijke verzorging

Basisonderwijs

VBO verzorging

MAVO

Andere opleidingstypen

dalend constant constant dalend
29

10

7

\section{7}

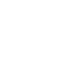

\section{Gezondheidszorg}

MBO/LLW verzorging

MBO/LLW verpleging

$\mathrm{HBO}$ verpleegkunde

HBO maatschappelijk werk en hulpverlening

Andere opleidingstypen

\section{Overige kwartaire diensten}

$\begin{array}{lrr}\text { HBO uitvoerende en beeldende kunsten } & 9 & \text { dalend } \\ \text { HAVONWO } & 7 & \text { dalend } \\ \text { MAVO } & 6 & \text { dalend } \\ \text { Andere opleidingstypen } & 78 & -\end{array}$

\section{Onderwijs}

HBO lerarenopleiding basisonderwijs HBO lerarenopleiding natuur en techniek HBO lerarenopleiding talen HBO lerarenopleiding economie en maatschappij Andere opleidingstypen dalend dalend dalend stijgend

dalend stijgend stijgend stijgend 
Tabel 1.10 (vervolg)

Belangrijkste opleidingstypen per bedrijfssector, gemiddelde 1995-1996

Bedrijfssector

$\%$

trend

1994-'96

Overheid

$M B O$ openbare orde en veiligheid

MBO/LLW administratie

MAVO

HAVONWO

8

stijgend

dalend

constant

Andere opleidingstypen

dalend

68

- 
Tabel 1.11

Conjunctuurgevoeligheid per bedrijfssector

\begin{tabular}{|c|c|c|}
\hline Bedrijfssector & conjunctuurgevoeligheid & typering \\
\hline Tuinbouw & 0,33 & erg laag \\
\hline Veehouderij & 0,33 & erg laag \\
\hline Akkerbouw, bosbouw en visserij & 0,33 & erg laag \\
\hline Vlees- en visverwerking & 1,02 & gemiddeld \\
\hline Overige voedingsproducten & 0,47 & laag \\
\hline Drank en tabaksproducten & 0,99 & gemiddeld \\
\hline Basischemie & 1,03 & gemiddeld \\
\hline Eindproducten chemie & 1,03 & gemiddeld \\
\hline Kunststofverwerking & 1,03 & gemiddeld \\
\hline Basismetaal & 1,19 & hoog \\
\hline Metaalproducten & 1,38 & erg hoog \\
\hline Machine-industrie & 1,39 & erg hoog \\
\hline Elektrotechniek & 1,72 & erg hoog \\
\hline Transportmiddelen & 1,09 & hoog \\
\hline Textiel & 1,28 & hoog \\
\hline Hout- en bouwmaterialen & 1,14 & hoog \\
\hline Papier & 0,70 & gemiddeld \\
\hline Grafische industrie & 0,95 & gemiddeld \\
\hline Energie & 1,13 & hoog \\
\hline Bouw & 1,68 & erg hoog \\
\hline Exploitatie van onroerend goed & 3,34 & erg hoog \\
\hline Handel & 0,48 & laag \\
\hline Scheeps-en luchtvaart & 1,17 & hoog \\
\hline Weg-en railvervoer & 0,67 & gemiddeld \\
\hline Communicatie & 0,67 & gemiddeld \\
\hline Bankwezen & 0,59 & laag \\
\hline Verzekeringswezen & 0,59 & laag \\
\hline Horeca & 0,46 & laag \\
\hline Reparatie & 0,46 & laag \\
\hline Zakelijke dienstverlening & 0,46 & laag \\
\hline Overige commerciële dienstverlening & 0,46 & laag \\
\hline Gezondheidszorg & 0,35 & erg laag \\
\hline Overige kwartaire diensten & 0,49 & laag \\
\hline Onderwijs & 0,47 & laag \\
\hline Overheid & 0,47 & laag \\
\hline
\end{tabular}

\section{Bron: ROA}

Toelichting:

De conjunctuurgevoeligheid van de werkgelegenheid heeft betrekking op de mate waarin de werkgelegenheid in de bedrijfssector gevoelig is voor veranderingen van de economische situatie. Deze indicator geeft daarmee de mate van werkzekerheid aan. 
Tabel 1.12

Verwachte uitbreidingsvraag per bedrijfssector, 1997-2002

\begin{tabular}{lrrrl}
\hline Bedrijfssector & aantal & $\begin{array}{c}\text { totaal } \\
\%\end{array}$ & $\begin{array}{c}\text { gemiddeld } \\
\text { jaarlijks \% }\end{array}$ & typering \\
& & & & \\
Landbouw en visserij & -10.400 & -5 & $-1,0$ & erg laag \\
Voeding & 3.500 & 2 & 0,4 & laag \\
Overige industrie & 47.800 & 9 & 1,8 & gemiddeld \\
Chemie & 9.900 & 5 & 0,9 & gemiddeld \\
Metaal en elektrotechniek & 11.600 & 9 & 1,7 & gemiddeld \\
Energie & -300 & -0 & $-0,1$ & erg laag \\
Bouw en onroerend goed & 18.200 & 4 & 0,8 & gemiddeld \\
Handel & 104.700 & 12 & 2,2 & hoog \\
Transport en communicatie & 29.100 & 8 & 1,5 & gemiddeld \\
Horeca, reparatie en zakelijke dienstverlening laag \\
Bank- en verzekeringswezen & 4.200 & 2 & 0,4 & erg hoog \\
Kwartaire diensten & 185.500 & 19 & 3,6 & gemiddeld \\
Overheid en onderwijs & 91.500 & 9 & 1,7 & laag \\
& 12.600 & 1 & 0,3 & gemiddeld \\
\hline Totaal & & & & 1,7 \\
\hline
\end{tabular}

Bron: ROA

Toelichting:

Uitbreidingsvraag is de vraag naar nieuwe arbeidskrachten die ontstaat door groei van de werkgelegenheid. Als er sprake is van een werkgelegenheidsdaling, is de uitbreidingsvraag negatief. 


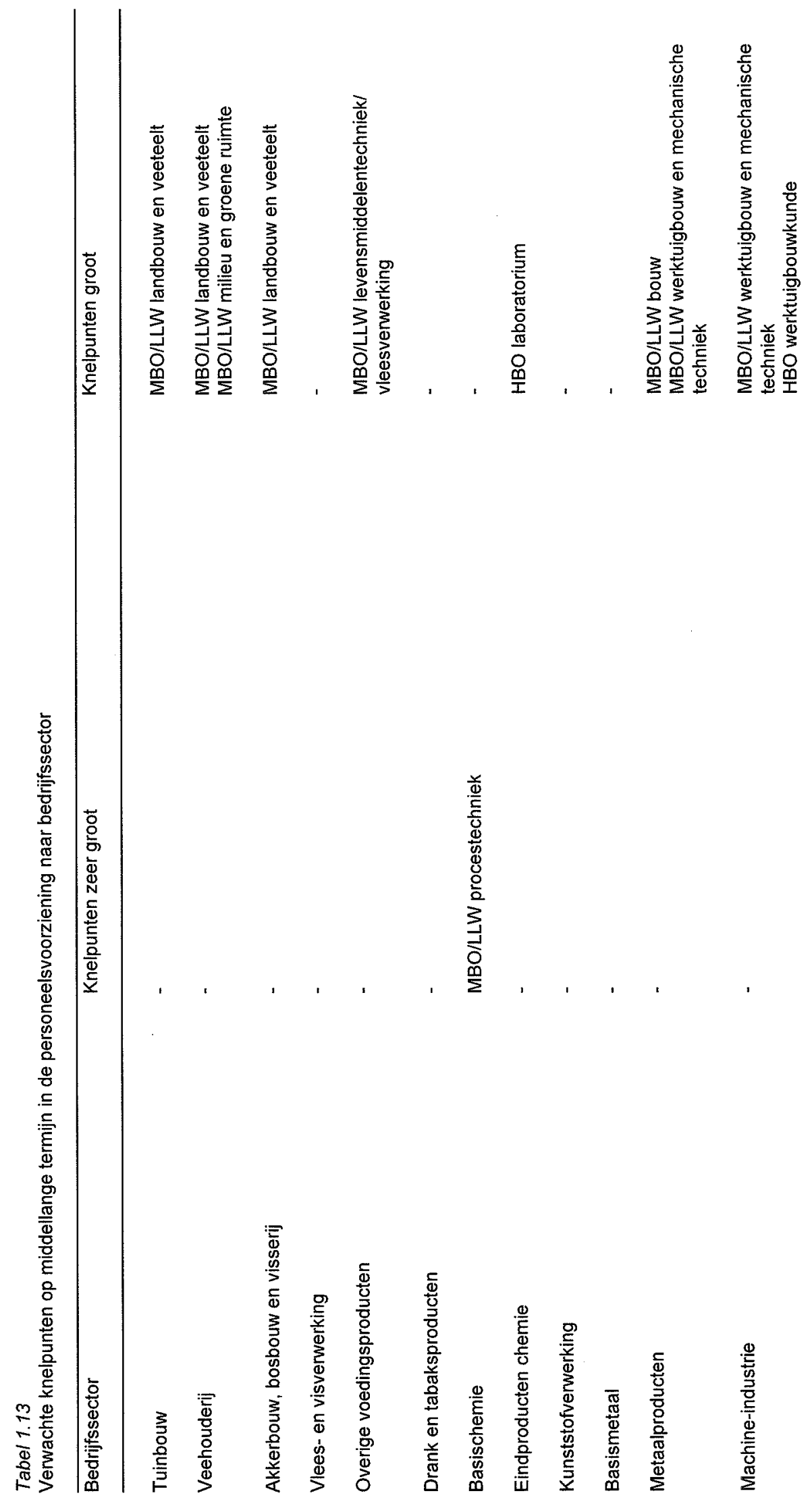




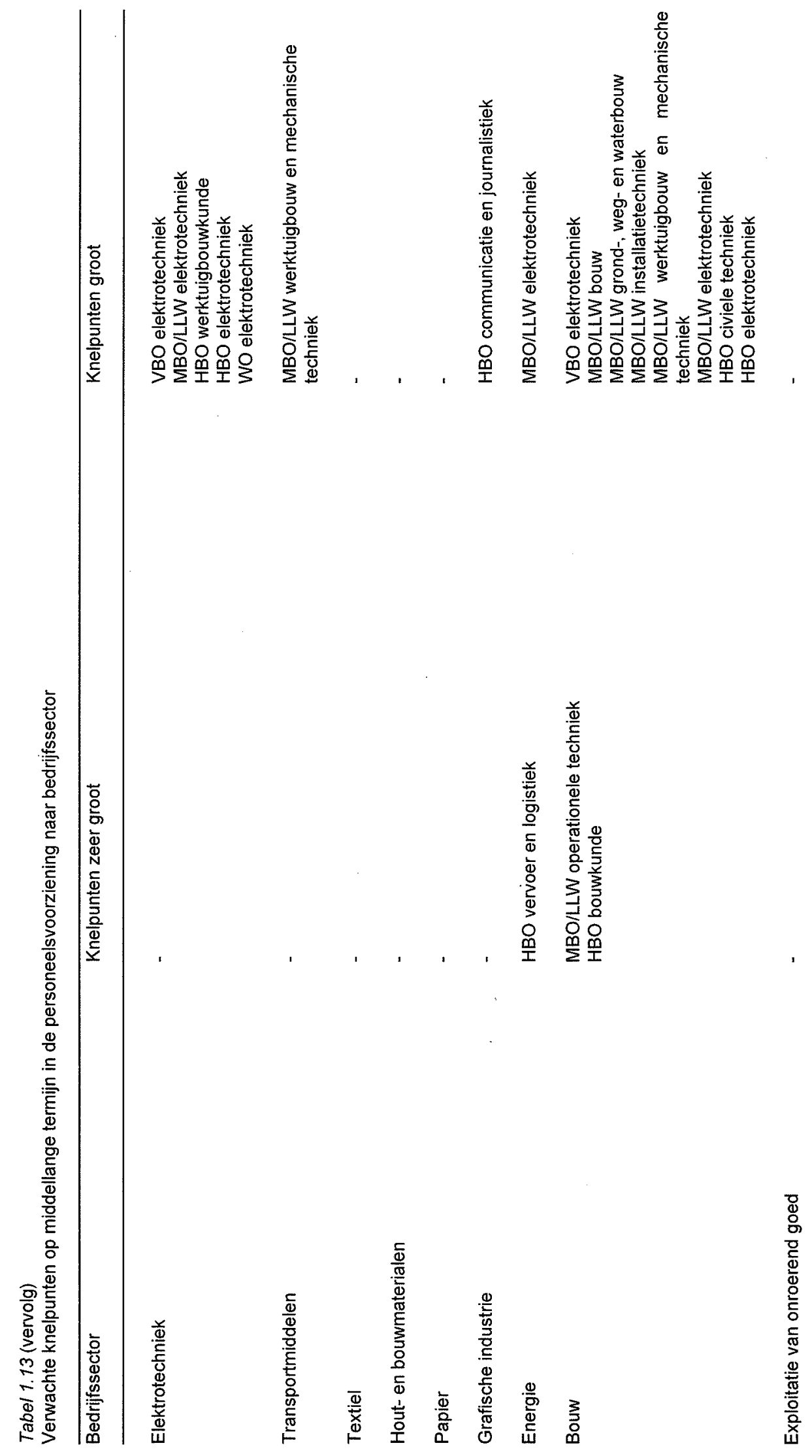




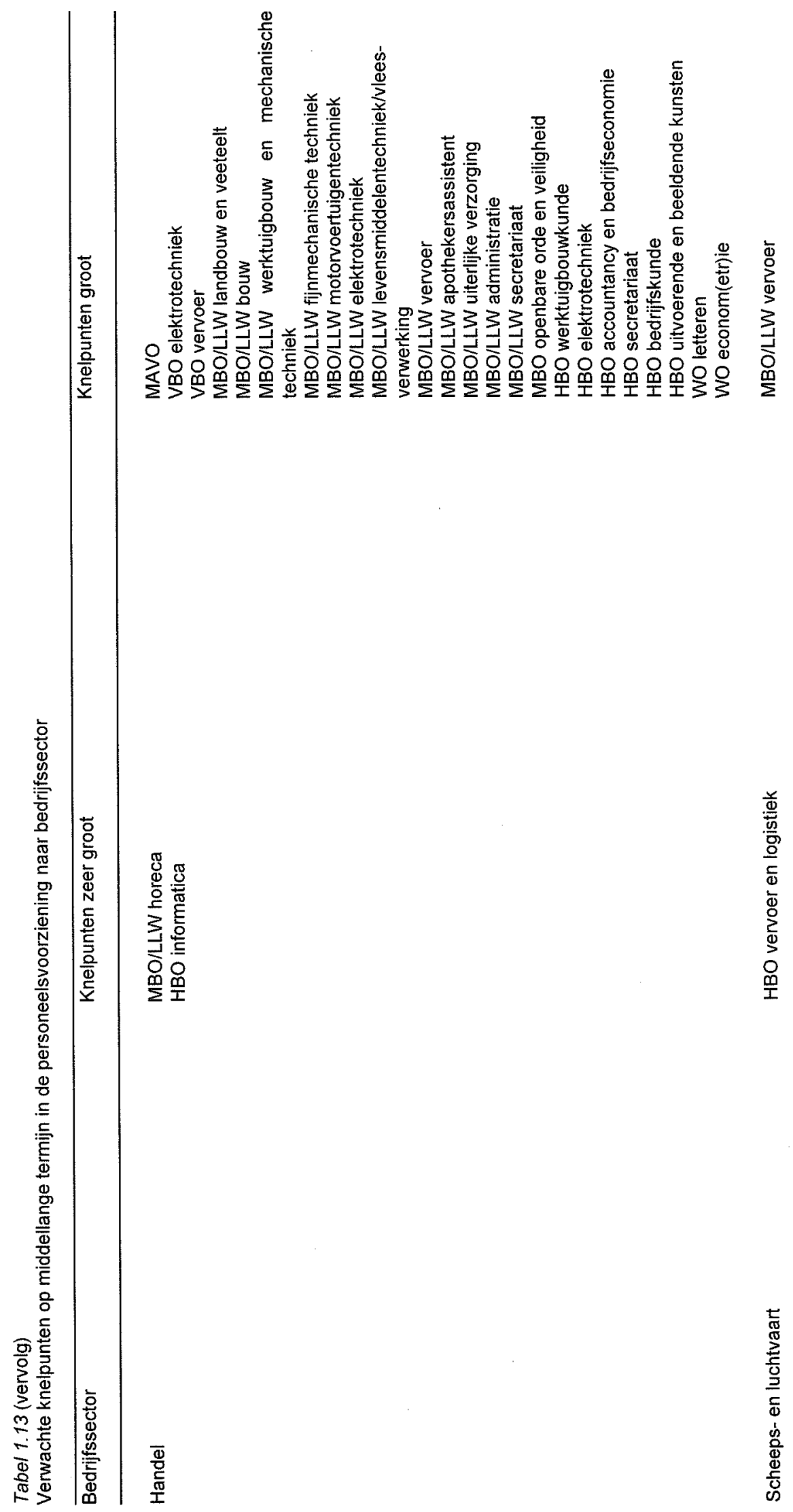




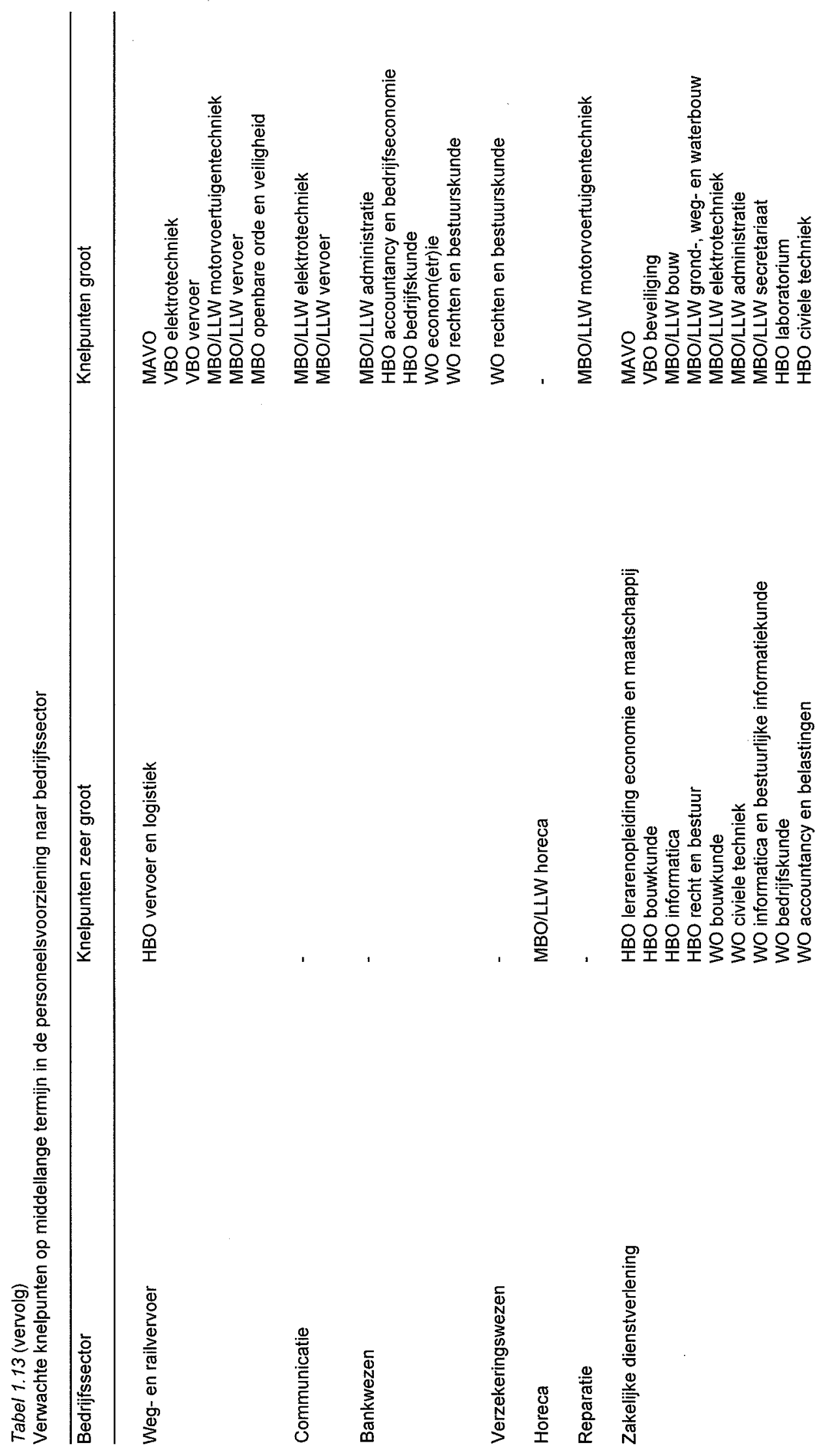




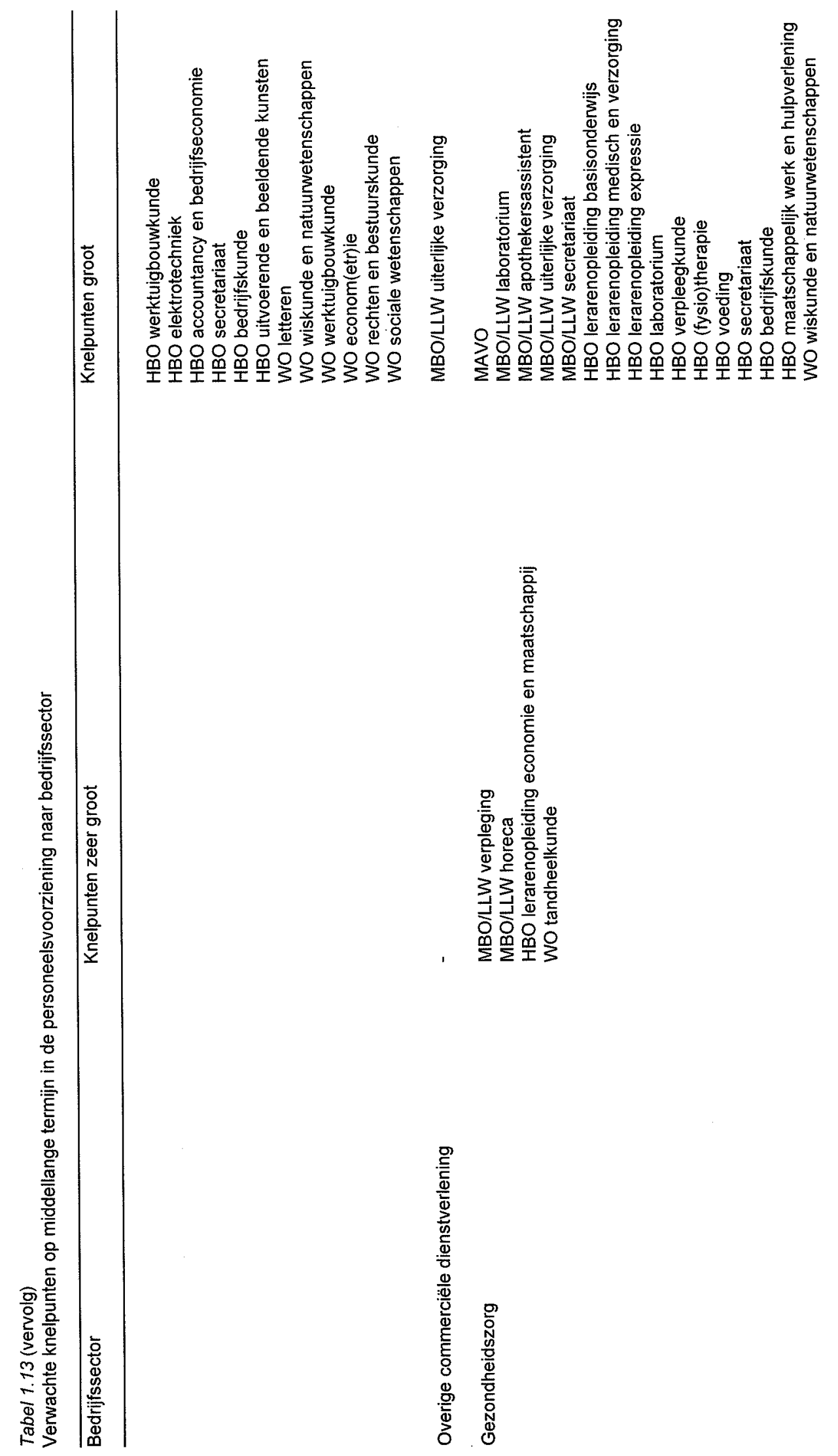




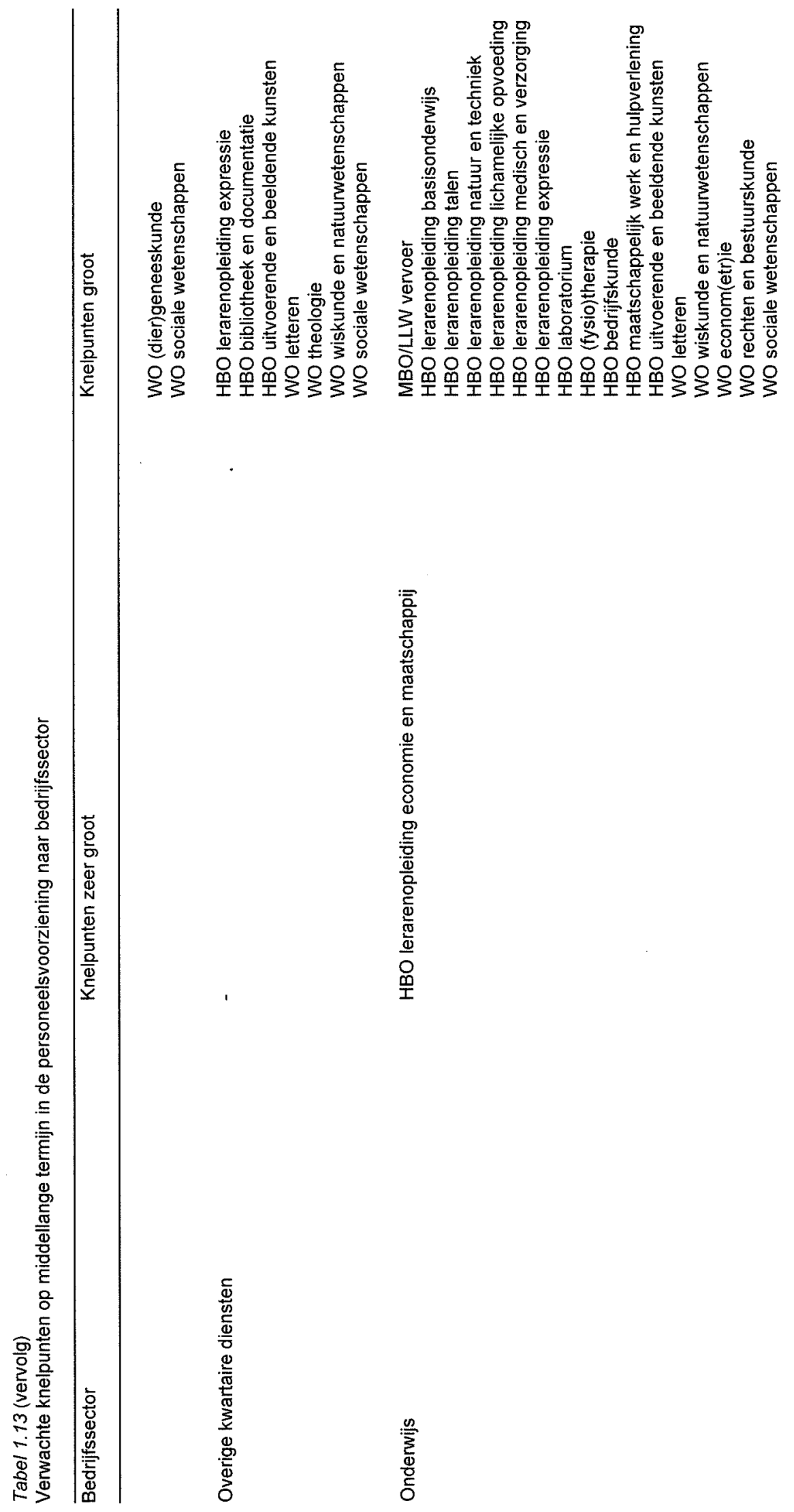




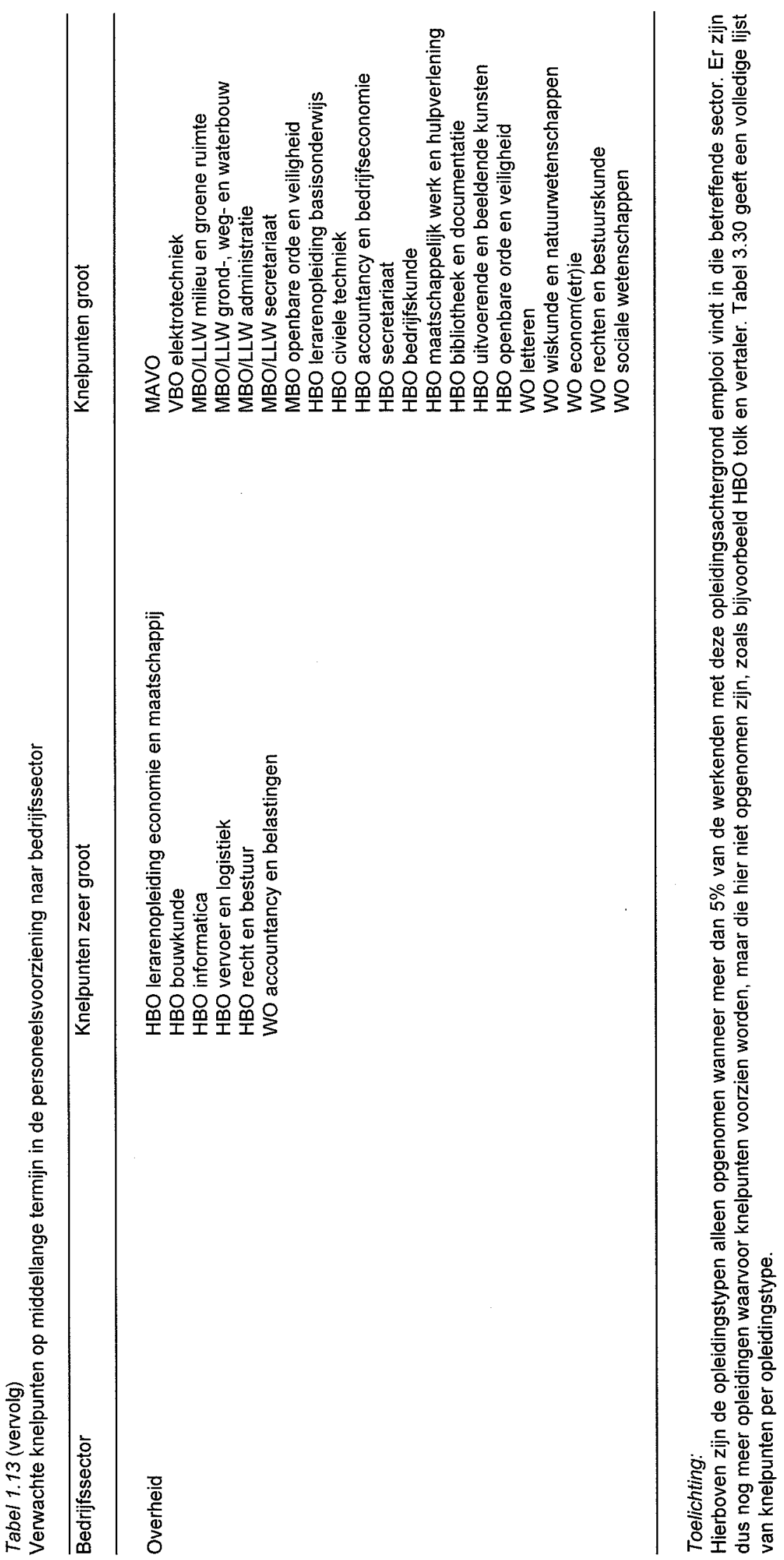


2 INFORMATIE OVER BEROEPEN 
Tabel 2.1

Aantal werkenden per beroepsgroep, gemiddelde 1995-1996

\begin{tabular}{lll}
\hline Beroepsgroep & aantal werkenden & trend \\
$1992-96$
\end{tabular}$\quad$ arbeidsvolume

\section{PEDAGOGISCHE BEROEPEN}

Leraar basisonderwijs

Docenten exacte, medische en verzorgende vakken

(2e graads)

Docenten exacte, medische en verzorgende vakken

(1e graads)

Docenten landbouw en techniek (2e graads)

Docenten landbouw en techniek (1e graads)

Docenten economisch-administratieve vakken

(2e en $3 e \mathrm{gr}$.)

Docenten economisch-administratieve vakken

(1e gr. en WO)

Docenten talen en expressie

Docenten letteren (1e graads)

Docenten sociale vakken (2e graads)

Docenten sociale vakken (1e graads)

Docenten 2 e graads zonder specialisatie

Docent 1 e graads zonder specialisatie

Onderwijskundig medewerkers

Onderwijskundigen en pedagogen

Rij-instructeurs

Zweminstructeurs

Sportinstructeurs

\section{CULTURELE BEROEPEN}

Tolken, vertalers en schrijvers

Bibliotheekassistenten

Bibliothecarissen

Grafisch ontwerpers

Kunstenaars

Geestelijk verzorgers

Geestelijken

Journalisten

Taalkundigen

\section{AGRARISCHE BEROEPEN}

Agrarische hulparbeiders

Agrarische arbeiders

6.000

108.000

9.500

14.500

4.500

Milieuhygiënisten en agrarisch vertegenwoordigers

Landbouwkundigen

Agrarische bedrijfshoofden

121.000
Landbouwmachinebestuurders en vissers stijgend

105.500

18.000

17.000

17.000

3.500

8.500

6.500

34.500

24.500

11.500

6.000

12.500

4.000

8.500

20.500

9.000

4.500

7.500

9.000

17.000

11.500

9.000

38.000

4.000

17.000

9.000

constant

15.500

stijgend

15.000

constant

16.000

3.500

constant

7.500

dalend

6.000

27.000

constant

21.000

stijgend

10.500

5.000

constant $\quad 11.000$

constant $\quad 4.000$

constant $\quad 7.500$

sterk stijgend 17.500

- $\quad 9.000$

constant $\quad 3.500$

sterk stijgend $\quad 7.000$ constant

$\begin{array}{lr}\text { stijgend } & 8.000 \\ \text { stijgend } & 13.500 \\ \text { - } & 9.000 \\ \text { stijgend } & 9.500 \\ \text { stijgend } & 37.000 \\ \text { - } & - \\ \text { dalend } & 4.000 \\ \text { - } & 15.000 \\ \text { stijgend } & 8.000\end{array}$

stijgend

4.500

constant $\quad 100.500$

dalend $\quad 9.000$

stijgend $\quad 14.000$

constant $\quad 4.000$

constant $\quad 13.500$

constant $\quad 163.500$

\section{TECHNISCHE EN INDUSTRIEBEROEPEN}

Productiemedewerkers

Laboratorium-assistenten

15.000

Laboranten

12.000

Technisch analisten

15.000

Natuurwetenschappers

26.500

Conciërges

11.500

\begin{tabular}{lr} 
stijgend & 100.000 \\
\hline- & 2.500 \\
constant & 14.000 \\
- & 11.000 \\
constant & 14.000 \\
constant & 23.000 \\
- & 11.500
\end{tabular}


Tabel 2.1 (vervolg)

Aantal werkenden per beroepsgroep, gemiddelde 1995-1996

\begin{tabular}{lll}
\hline Beroepsgroep & aantal werkenden & trend \\
$1992-96$
\end{tabular}$\quad$ arbeidsvolume

Werktuigbouwkundigen

Bouwvakkers

Aannemers en installateurs

Architecten en bouwkundig projectleiders

Weg- en waterbouwkundigen

Weg- en waterbouwkundige arbeiders

Weg-en waterbouwkundige vakkrachten

Weg- en waterbouwkundig ontwerpers en projectleiders

Metaalarbeiders

Bankwerkers en lassers

Bedrijfshoofden metaalbewerking

Assembleurs

Monteurs

Werktuigbouwkundig ontwerpers en hoofden technische

dienst

Elektronicamonteurs

Monteurs en controleurs elektrotechnische producten

Elektromonteurs

Elektrotechnisch ontwerpers en bedrijfshoofden

Elektrotechnici

Grafisch productiepersoneel

Grafische vakkrachten

Mechanisch operators

Procesoperators

Procestechnologen

Materiaalkundigen

Confectie-arbeiders

Schoen- en kleermakers

\section{TRANSPORTBEROEPEN}

Laders en lossers

Chauffeurs

93.000

220.000

16.000

Schippers en conducteurs

15.000

9.500

Stewards

\section{MEDISCHE EN PARAMEDISCHE BEROEPEN}

Verpleeghulpen en leerling-verpleegkundigen

Verplegenden en doktersassistenten

24.000

106.500

Therapeuten en verpleegkundigen

Artsen

Apothekersassistenten en medisch laboranten

Medisch analisten

Apothekers

Afdelingshoofden zorginstelling

89.500

52.500

33.500

15.000

5.000

10.500
11.500

constant $\quad 169.500$

stijgend $\quad 174.000$

stijgend $\quad 32.000$

dalend $\quad 11.500$

constant $\quad 24.500$

constant $\quad 33.500$

constant $\quad 8.000$

constant $\quad 87.500$

constant $\quad 59.000$

constant $\quad 4.500$

stijgend $\quad 20.000$

constant $\quad 189.000$

stijgend $\quad 31.500$

dalend $\quad 12.500$

dalend $\quad 16.500$

constant $\quad 87.000$

-

dalend

10.000

7.000

dalend $\quad 22.500$

constant $\quad 37.000$

constant $\quad 72.500$

constant $\quad 46.000$

constant $\quad 10.500$

constant $\quad 15.000$

constant $\quad 30.500$

constant $\quad 7.500$

stijgend

constant

dalend

stijgend

stijgend

85.000

218.500

17.000

15.500

8.000

\section{ECONOMISCH-AIDMINISTRATIEVE BEROEPEN}

Kantoorhulpen, inpakkers en colporteurs

Ondersteunende administratieve hulpkrachten

$\begin{array}{lr}\text { constant } & 19.500 \\ \text { constant } & 79.500 \\ \text { constant } & 71.500 \\ \text { stijgend } & 56.000 \\ \text { constant } & 27.500 \\ \text { constant } & 12.000 \\ \text { - } & 5.000 \\ \text { - } & 9.000\end{array}$


Tabel 2.1 (vervolg)

Aantal werkenden per beroepsgroep, gemiddelde 1995-1996

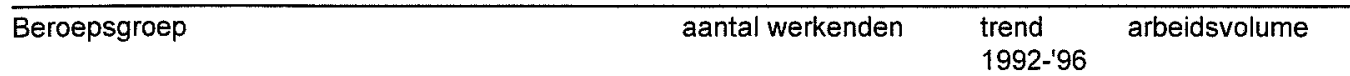

Organisatiedeskundigen

Receptionisten en administratieve employés

Boekhouders en secretaresses

Assistent accountants

Accountants

Verzekeringsagenten

Commercieel employés

Commercieel medewerkers

Technisch-commercieel employés

Technisch-bedrijfskundig medewerkers

Juridisch en fiscaal medewerkers

Juridisch, bestuurlijk medewerkers

Juristen

Administratieve transportemployés

Leidinggevenden

Managers

Medisch secretaresses

\section{INFORMATICABEROEPEN}

\section{Programmeurs}

Systeemanalisten

Informatici

Technisch systeemanalisten
17.000

218.500

382.500

91.000

25.500

26.500

266.500

180.500

19.000

12.000

34.500

16.000

50.000

27.000

42.500

72.500

16.000

51.000

78.500

14.500

10.000

$\begin{array}{lr}\text { constant } & 17.000 \\ \text { stijgend } & 171.000 \\ \text { constant } & 324.000 \\ \text { sterk stijgend } & 25.500 \\ \text { constant } & 23.500 \\ \text { constant } & 249.500 \\ \text { constant } & 196.500 \\ \text { constant } & 19.000 \\ \text { constant } & 12.000 \\ \text { constant } & 32.500 \\ \text { dalend } & 15.500 \\ \text { stijgend } & 48.500 \\ \text { constant } & 28.500 \\ \text { stijgend } & 45.000 \\ \text { stijgend } & 73.000 \\ \text { stijgend } & 11.500\end{array}$

stijgend

49.500

constant $\quad 76.500$

constant $\quad 15.000$

constant $\quad 10.000$

\section{SOCIAAL-CULTURELE BEROEPEN}

Activiteitenbegeleiders en medewerkers arbeidsbemiddeling

50.000

Sociaal-cultureel werkers

Sociale raadslieden en hoofden personeelszaken

Sociaal-wetenschappelijk medewerkers

Sociaal-wetenschappelijk onderzoekers
72.500

9.500

6.500

19.500

\section{VERZORGENDE EN DIENSTVERLENENDE BEROEPEN}

\author{
Vakkenvullers \\ Interieurverzorgers \\ Verkopers \\ Winkeliers \\ Hulpkrachten horeca en verzorging \\ Ziekenverzorgenden \\ Verzorgend personeel \\ Café- en snackbarhouders \\ Bedrijfshoofden horeca \\ Bakkers en slagers
}

20.500
142.500
239.000
130.000
139.500
56.000
195.000
12.500
39.500
15.500

$\begin{array}{lr}\text { sterk stijgend } & 40.500 \\ \text { constant } & 62.000 \\ \text { constant } & 8.000 \\ \text { constant } & 6.000 \\ \text { - } & 17.000\end{array}$

$\begin{array}{lr}\text { stijgend } & 13.500 \\ \text { stijgend } & 92.500 \\ \text { constant } & 178.000 \\ \text { constant } & 146.500 \\ \text { constant } & 92.500 \\ \text { stijgend } & 40.000 \\ \text { constant } & 148.500 \\ \text { constant } & 18.000 \\ \text { sterk stijgend } & 49.500 \\ \text { dalend } & 19.000\end{array}$


Tabel 2.1 (vervolg)

Aantal werkenden per beroepsgroep, gemiddelde 1995-1996

\begin{tabular}{lll}
\hline Beroepsgroep & aantal werkenden & trend \\
$1992-' 96$ & arbeidsvolume
\end{tabular}

\section{OPENBARE ORDE- EN VEILIGHEIDSBEROEPEN}

Aspirant politieagenten, soldaten en beveiligingshulp-

Politieagenten, onderofficieren en beveiligingsemployés

39.500

stijgend

37.000

Politie-inspecteurs en officieren

46.000

constant

44.000

Brandweerlieden

7.500

constant $\quad 7.500$

Totaal

6.115 .000

constant $\quad 5.623 .000$

\section{Bron: CBS/ROA}

\section{Toelichting:}

Arbeidsvolume is het totaal aantal normaal gewerkte arbeidsuren gedeeld door 40 . Het aantal werkenden heeft betrekking op iedereen die jonger is dan 65 jaar en minstens 12 uur per week werkt. 
Tabel 2.2

Percentage vrouwen per beroepsgroep, gemiddelde 1995-1996

Beroepsgroep $\quad \% \quad$ typering trend

\section{PEDAGOGISCHE BEROEPEN}

Leraar basisonderwijs

Docenten exacte, medische en verzorgende vakken

(2e graads)

Docenten exacte, medische en verzorgende vakken

(1e graads)

Docenten landbouw en techniek ( 2 e graads)

Docenten landbouw en techniek (1e graads)

Docenten economisch-administratieve vakken (2e graads)

Docenten economisch-administratieve vakken (1e graads)

Docenten talen en expressie

Docenten letteren (1e graads)

Docenten sociale vakken (2e graads)

Docenten sociale vakken (1e graads)

Docenten 2 e graads zonder specialisatie

Docent 1 e graads zonder specialisatie

Onderwijskundig medewerkers

Onderwijskundigen en pedagogen

Rij-instructeurs

Zweminstructeurs

Sportinstructeurs

\section{CULTURELE BEROEPEN}

Tolken, vertalers en schrijvers

Bibliotheekassistenten

Bibliothecarissen

Grafisch ontwerpers

Kunstenaars

Geestelijk verzorgers

Geestelijken

Journalisten

Taalkundigen

\section{AGRARISCHE BEROEPEN}

Agrarische hulparbeiders

Agrarische arbeiders

Agrarische vakkrachten

Milieuhygiënisten en agrarisch vertegenwoordigers

Landbouwkundigen

Landbouwmachinebestuurders en vissers

Agrarische bedrijfshoofden

\section{TECHNISCHE EN INDUSTRIEBEROEPEN}

Productiemedewerkers

Laboratorium-assistenten

Laboranten

Technisch analisten

Natuurwetenschappers

Conciërges

Hoofden technische dienst

Werktuigbouwkundigen

Bouwvakkers

$\begin{array}{rll}69 & \text { hoog } & \text { constant } \\ 45 & \text { gemiddeld } & \text { dalend } \\ & & \\ 26 & \text { gemiddeld } & \text { stijgend } \\ 14 & \text { gemiddeld } & \text { dalend } \\ - & \text { gemiddeld } & - \\ 36 & \text { gemiddeld } & \text { stijgend } \\ - & \text { gemiddeld } & \text { dalend } \\ 56 & \text { hoog } & \text { constant } \\ 45 & \text { gemiddeld } & \text { constant } \\ 31 & \text { gemiddeld } & - \\ 41 & \text { gemiddeld } & \text { stijgend } \\ 37 & \text { gemiddeld } & \text { constant } \\ - & \text { gemiddeld } & - \\ 41 & \text { gemiddeld } & \text { sterk dalend } \\ 56 & \text { hoog } & \text { stijgend } \\ - & \text { gemiddeld } & - \\ 60 & \text { hoog } & \text { constant } \\ 32 & \text { gemiddeld } & \text { constant }\end{array}$

hoog

hoog

hoog

gemiddeld

gemiddeld

gemiddeld

gemiddeld

gemiddeld

constant

constant

constant

stijgend

constant

constant

sterk stijgend

hoog

gemiddeld

gemiddeld

gemiddeld

gemiddeld

erg laag stijgend

dalend

dalend

constant sterk stijgend

sterk stijgend

constant

stijgend

constant

constant

stijgend

constant

gemiddeld

erg laag

erg laag

erg laag

constant 
Beroepsgroep $\quad \% \quad$ typering trend

1992-'96

Aannemers en installateurs

Architecten en bouwkundig projectleiders

Weg- en waterbouwkundigen

Weg-en waterbouwkundige arbeiders

Weg-en waterbouwkundige vakkrachten

Weg-en waterbouwkundig ontwerpers en projectleiders

Metaalarbeiders

Bankwerkers en lassers

Bedrijfshoofden metaalbewerking

Assembleurs

Monteurs

Werktuigbouwkundig ontwerpers en hoofden technische dienst -

Elektronicamonteurs

Monteurs en controleurs elektrotechnische producten

Elektromonteurs

Elektrotechnisch ontwerpers en bedrijfshoofden

Elektrotechnici

Grafisch productiepersonee

Grafische vakkrachten

Mechanisch operators

Procesoperators

Procestechnologen

Materiaalkundigen

Confectie-arbeiders

Schoen- en kleermakers

\section{TRANSPORTBEROEPEN}

Laders en lossers

Chauffeurs

Schippers en conducteurs

Vliegers, scheepskapiteins en leidinggevenden transport

Stewards

13

5

$-$

$\begin{array}{ll}\text { erg laag } & \text { sterk stijgend } \\ \text { laag } & \text { - } \\ \text { laag } & \text { constant } \\ \text { erg laag } & - \\ \text { erg laag } & - \\ \text { laag } & \text { - } \\ \text { erg laag } & \text { dalend } \\ \text { laag } & \text { - } \\ \text { gemiddeld } & \text { - } \\ \text { erg laag } & \text { sterk stijgend } \\ \text { erg laag } & \text { constant } \\ \text { erg laag } & \text { constant } \\ \text { erg laag } & \text { constant } \\ \text { laag } & \text { stijgend } \\ \text { erg laag } & \text { - } \\ \text { erg laag } & \text { sterk dalend } \\ \text { erg laag } & - \\ \text { gemiddeld } & \text { constant } \\ \text { gemiddeld } & \text { stijgend } \\ \text { gemiddeld } & \text { constant } \\ \text { erg laag } & \text { constant } \\ \text { laag } & \text { dalend } \\ \text { gemiddeld } & - \\ \text { hoog } & \text { dalend } \\ \text { gemiddeld } & \text { sterk dalend }\end{array}$

gemiddeld erg laag

laag

laag

hoog constant constant sterk stijgend sterk stijgend dalend

constant constant constant stijgend constant constant constant constant
Verpleeghulpen en leerling-verpleegkundigen

Verplegenden en doktersassistenten

Therapeuten en verpleegkundigen

Artsen

Apothekersassistenten en medisch laboranten

Medisch analisten

Apothekers

Afdelingshoofden zorginstelling

\section{ECONOMISCH-ADMINISTRATIEVE BEROEPEN}

Kantoorhulpen, inpakkers en colporteurs

Ondersteunende administratieve hulpkrachten

Bedrijfshoofden

Economen

Productieplanners

Organisatie-adviseurs

Organisatiedeskundigen

Receptionisten en administratieve employés

Boekhouders en secretaresses hoog

hoog

gemiddeld

hoog

hoog

hoog

hoog

gemiddeld

gemiddeld

gemiddeld

gemiddeld

gemiddeld

gemiddeld

hoog

hoog constant

dalend

stijgend constant dalend

dalend constant constant 
Tabel 2.2 (vervolg)

Percentage vrouwen per beroepsgroep, gemiddelde 1995-1996

Beroepsgroep $\%$ typering trend

1992-'96

Assistent accountants

37

Accountants

Verzekeringsagenten

Commercieel employés

Commercieel medewerkers

Technisch-commercieel employés

Technisch-bedrijfskundig medewerkers

Juridisch en fiscaal medewerkers

Juridisch, bestuurlijk medewerkers

Juristen

Administratieve transportemployés

Leidinggevenden

Managers

Medisch secretaresses

\section{INFORMATICABEROEPEN}

Programmeurs

Systeemanalisten

Informatici

Technisch systeemanalisten

\section{SOCIAAL-CULTURELE BEROEPEN}

Activiteitenbegeleiders en medewerkers arbeidsbemiddeling 63

Sociaal-cultureel werkers

Sociale raadslieden en hoofden personeelszaken

Sociaal-wetenschappelijk medewerkers

Sociaal-wetenschappelijk onderzoekers

\section{VERZORGENDE EN DIENSTVERLENENDE BEROEPEN}

Vakkenvullers

Interieurverzorgers

Verkopers

Winkeliers

Hulpkrachten horeca en verzorging

Ziekenverzorgenden

Verzorgend personeel

Café- en snackbarhouders

Bedrijfshoofden horeca

Bakkers en slagers

\section{OPENBARE ORDE- EN VEILIGHEIDSBEROEPEN}

Aspirant politieagenten, soldaten en beveiligingshulpkrachten 13

Politieagenten, onderofficieren en beveiligingsemployés $\quad 14$

Politie-inspecteurs en officieren

Brandweerlieden

Totaal

$\begin{array}{ll}\text { gemiddeld } & \text { constant } \\ \text { gemiddeld } & - \\ \text { hoog } & \text { constant } \\ \text { gemiddeld } & \text { constant } \\ \text { gemiddeld } & \text { stijgend } \\ \text { gemiddeld } & \text { sterk stijgend } \\ \text { gemiddeld } & - \\ \text { gemiddeld } & \text { stijgend } \\ \text { gemiddeld } & \text { constant } \\ \text { gemiddeld } & \text { stijgend } \\ \text { gemiddeld } & \text { dalend } \\ \text { laag } & \text { dalend } \\ \text { gemiddeld } & \text { sterk stijgend } \\ \text { erg hoog } & \text { constant }\end{array}$

gemiddeld gemiddeld gemiddeld laag

sterk dalend

constant

constant

sterk stijgend

$\begin{array}{ll}\text { hoog } & \text { stijgend } \\ \text { hoog } & \text { stijgend } \\ \text { hoog } & \text { stijgend } \\ \text { gemiddeld } & \text { constant } \\ \text { gemiddeld } & \text { constant }\end{array}$

$\begin{array}{ll}\text { gemiddeld } & \text { constant } \\ \text { hoog } & \text { constant } \\ \text { hoog } & \text { constant } \\ \text { gemiddeld } & \text { constant } \\ \text { hoog } & \text { constant } \\ \text { erg hoog } & \text { constant } \\ \text { hoog } & \text { constant } \\ \text { gemiddeld } & \text { constant } \\ \text { gemiddeld } & \text { dalend } \\ \text { gemiddeld } & \text { sterk stijgend }\end{array}$

gemiddeld sterk stijgend gemiddeld sterk stijgend erg laag laag

gemiddeld constant

Bron: CBS/ROA 
Tabel 2.3

Percentage allochtonen per beroepsgroep, gemiddelde 1995-1996

Beroepsgroep $\quad \% \quad$ typering trend

\section{PEDAGOGISCHE BEROEPEN}

Leraar basisonderwijs

Docenten exacte, medische en verzorgende vakken

(2e graads)

Docenten exacte, medische en verzorgende vakken

(1e graads)

Docenten landbouw en techniek (2e graads)

Docenten landbouw en techniek (1e graads)

Docenten economisch-administratieve vakken (2e graads)

Docenten economisch-administratieve vakken (1e graads)

Docenten talen en expressie

Docenten letteren (1e graads)

Docenten sociale vakken (2e graads)

Docenten sociale vakken (1e graads)

Docenten $2 \mathrm{e}$ graads zonder specialisatie

Docent 1e graads zonder specialisatie

Onderwijskundig medewerkers

Onderwijskundigen en pedagogen

Rij-instructeurs

Zweminstructeurs

Sportinstructeurs

\section{CULTURELE BEROEPEN}

Tolken, vertalers en schrijvers

Bibliotheekassistenten

Bibliothecarissen

Grafisch ontwerpers

Kunstenaars

Geestelijk verzorgers

Geestelijken

Journalisten

Taalkundigen

\section{AGRARISCHE BEROEPEN}

Agrarische hulparbeiders

Agrarische arbeiders

Agrarische vakkrachten

Milieuhygiënisten en agrarisch vertegenwoordigers

Landbouwkundigen

Landbouwmachinebestuurders en vissers

Agrarische bedriffshoofden

\section{TECHNISCHE EN INDUSTRIEBEROEPEN}

Productiemedewerkers

Laboratorium-assistenten

Laboranten

Technisch analisten

Natuurwetenschappers

Conciërges

Hoofden technische dienst

Werktuigbouwkundigen

Bouwvakkers
3

$-$

$-$

-

$\begin{array}{ll}\text { gemiddeld } & - \\ \text { gemiddeld } & - \\ \text { laag } & - \\ \text { laag } & - \\ \text { laag } & - \\ \text { - } & - \\ \text { laag } & - \\ \text { erg laag } & \text { sterk dalend } \\ \text { erg laag } & -\end{array}$

gemiddeld

gemiddeld

constant

erg laag

laag

laag

gemiddeld

gemiddeld

gemiddeld

erg laag

aag

hoog

gemiddeld

gemiddeld

sterk dalend constant

-

-

-

-

- erg hoog gemiddeld erg laag laag erg laag laag erg laag

$$
\begin{aligned}
& \text { sterk stijgend } \\
& \text { - } \\
& \text { - } \\
& \text { - } \\
& \text { - } \\
& \text { - } \\
& \text { - }
\end{aligned}
$$

constant

$\begin{array}{ll}\text { erg hoog } & \text { constant } \\ \text { gemiddeld } & - \\ \text { gemiddeld } & - \\ \text { laag } & - \\ \text { laag } & - \\ \text { hoog } & - \\ \text { erg laag } & - \\ \text { gemiddeld } & - \\ \text { gemiddeld } & \text { dalend }\end{array}$


Tabel 2.3 (vervolg)

Percentage allochtonen per beroepsgroep, gemiddelde 1995-1996

Beroepsgroep $\quad \% \quad$ typering trend

1992-'96

Aannemers en installateurs

Architecten en bouwkundig projectleiders

Weg-en waterbouwkundigen

Weg- en waterbouwkundige arbeiders

Weg- en waterbouwkundige vakkrachten

Weg- en waterbouwkundig ontwerpers en projectleiders

Metaalarbeiders

Bankwerkers en lassers

Bedrijfshoofden metaalbewerking

Assembleurs

Monteurs

Werktuigbouwkundig ontwerpers en hoofden technische dienst-

Elektronicamonteurs

Monteurs en controleurs elektrotechnische producten

Elektromonteurs

Elektrotechnisch ontwerpers en bedrijfshoofden

Elektrotechnici

Grafisch productiepersoneel

Grafische vakkrachten

Mechanisch operators

Procesoperators

Procestechnologen

Materiaalkundigen

Confectie-arbeiders

Schoen- en kleermakers

\section{TRANSPORTBEROEPEN}

Laders en lossers

Chauffeurs

Schippers en conducteurs

Vliegers, scheepskapiteins en leidinggevenden transport

Stewards

\section{MEDISCHE EN PARAMEDISCHE BEROEPEN}

Verpleeghulpen en leerling-verpleegkundigen

Verplegenden en doktersassistenten

Therapeuten en verpleegkundigen

Artsen

Apothekersassistenten en medisch laboranten

Medisch analisten

Apothekers

Afdelingshoofden zorginstelling

\section{ECONOMISCH-ADMINISTRATIEVE BEROEPEN}

Kantoorhulpen, inpakkers en colporteurs

Ondersteunende administratieve hulpkrachten

Bedrijfshoofden

Economen

Productieplanners

Organisatie-adviseurs

Organisatiedeskundigen

Receptionisten en administratieve employés

Boekhouders en secretaresses

laag
laag
laag
laag
laag
gemiddeld
erg hoog
hoog
erg laag
erg hoog
gemiddeld
gemiddeld
hoog
erg hoog
gemiddeld
gemiddeld
gemiddeld
hoog
hoog
erg hoog
hoog
laag
laag
erg hoog
hoog

constant

sterk stijgend

sterk dalend

constant

sterk stijgend

sterk stijgend

sterk stijgend

sterk stijgend

constant

-

dalend

sterk stijgend

constant

-

sterk stijgend

-

$\begin{array}{ll}\text { erg hoog } & \text { dalend } \\ \text { gemiddeld } & - \\ \text { hoog } & - \\ \text { hoog } & - \\ \text { erg hoog } & -\end{array}$

erg hoog

gemiddeld

gemiddeld

gemiddeld

gemiddeld

gemiddeld

gemiddeld

erg laag

erg hoog

hoog

laag

laag

gemiddeld

gemiddeld

laag

hoog

gemiddeld sterk stijgend

sterk stijgend

dalend

-

-

constant

sterk stijgend

constant

stijgend 
Tabel 2.3 (vervolg)

Percentage allochtonen per beroepsgroep, gemiddelde 1995-1996

\begin{tabular}{llll}
\hline Beroepsgroep & $\%$ & typering & trend
\end{tabular}

1992-'96

Assistent accountants

Accountants

Verzekeringsagenten

Commercieel employés

Commercieel medewerkers

Technisch-commercieel employés

Technisch-bedrijfskundig medewerkers

Juridisch en fiscaal medewerkers

Juridisch, bestuurlijk medewerkers

Juristen

Administratieve transportemployés

Leidinggevenden

Managers

Medisch secretaresses

\section{INFORMATICABEROEPEN}

Programmeurs

Systeemanalisten

Informatici

Technisch systeemanalisten

\section{SOCIAAL-CULTURELE BEROEPEN}

Activiteitenbegeleiders en medewerkers arbeidsbemiddeling Sociaal-cultureel werkers

Sociale raadslieden en hoofden personeelszaken

Sociaal-wetenschappelijk medewerkers

Sociaal-wetenschappelijk onderzoekers

\section{VERZORGENDE EN DIENSTVERLENENDE BEROEPEN}

\author{
Vakkenvullers \\ Interieurverzorgers \\ Verkopers \\ Winkeliers \\ Hulpkrachten horeca en verzorging \\ Ziekenverzorgenden \\ Verzorgend personeel \\ Café- en snackbarhouders \\ Bedrijfshoofden horeca \\ Bakkers en slagers
}

gemiddeld
gemiddeld
gemiddeld
gemiddeld
laag
laag
gemiddeld
gemiddeld
erg laag
gemiddeld
gemiddeld
gemiddeld
laag
hoog

sterk stijgend sterk dalend stijgend

$-$

$-$ sterk stijgend constant sterk stijgend sterk stijgend

gemiddeld gemiddeld laag gemiddeld

sterk stijgend sterk stijgend hoog

laag erg laag gemiddeld

gemiddeld erg hoog gemiddeld gemiddeld erg hoog gemiddeld gemiddeld hoog hoog laag

$\begin{array}{lll}- & \text { hoog } & - \\ - & \text { gemiddeld } & \text { sterk stijgend } \\ - & \text { laag } & - \\ - & \text { laag } & - \\ 3 & \text { gemiddeld } & \text { stijgend }\end{array}$


Toelichting:

Het percentage allochtonen heeft betrekking op iedereen die een niet-Nederlandse nationaliteit bezit, of die buiten Nederland is geboren, in één van de landen die genoemd worden in de Wet Bevordering Evenredige Arbeidsdeelname Allochtonen (WBEAA). Deze landen zijn: Aruba, Nederlandse Antillen, Ethiopië, Irak, Iran, voormalige Joegoslavië, Marokko, Somalië, Suriname, Turkijke en Vietnam. Op grond van deze wet zouden echter ook kinderen van allochtonen tot de doelgroep gerekend moeten worden, ongeacht of zij een nietNederlandse nationaliteit bezitten. 
Tabel 2.4

Percentage jongeren (15-29 jaar) en ouderen (50-64 jaar) per beroepsgroep, gemiddelde 1995-1996

\begin{tabular}{|c|c|c|c|}
\hline Beroepsgroep & jongeren & ouderen & \\
\hline & $\%$ & $\begin{array}{l}\text { trend } \\
1992-96\end{array}$ & $\begin{array}{l}\text { trend } \\
1992-396\end{array}$ \\
\hline
\end{tabular}

\section{PEDAGOGISCHE BEROEPEN}

Leraar basisonderwijs

Docenten exacte, medische en verzorgende vakken

(2e graads)

Docenten exacte, medische en verzorgende vakken (1e graads)

Docenten landbouw en techniek (2e graads)

Docenten landbouw en techniek (1e graads)

Docenten economisch-administratieve vakken

( $2 \mathrm{e}$ en $3 \mathrm{e} \mathrm{gr}$.)

Docenten economisch-administratieve vakken

(1e gr. en WO)

Docenten talen en expressie

Docenten letteren (1e graads)

Docenten sociale vakken (2e graads)

Docenten sociale vakken (1e graads)

Docenten $2 \mathrm{e}$ graads zonder specialisatie

Docent 1 e graads zonder specialisatie

Onderwijskundig medewerkers

Onderwijskundigen en pedagogen

Rij-instructeurs

Zweminstructeurs

Sportinstructeurs

\section{CULTURELE BEROEPEN}

Tolken, vertalers en schrijvers

Bibliotheekassistenten

Bibliothecarissen

Grafisch ontwerpers

Kunstenaars

Geestelijk verzorgers

Geesteiijken

Journalisten

Taalkundigen

\section{AGRARISCHE BEROEPEN}

Agrarische hulparbeiders

Agrarische arbeiders

Agrarische vakkrachten

Milieuhygiënisten en agrarisch vertegenwoordigers

Landbouwkundigen

Landbouwmachinebestuurders en vissers

Agrarische bedrijfshoofden
14

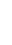

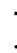

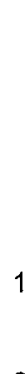

\section{TECHNISCHE EN INDUSTRIEBEROEPEN}

Productiemedewerkers

Laboratorium-assistenten

Laboranten

Technisch analisten

Natuurwetenschappers

Conciërges

$$
\text { dalend }
$$

sterk dalend 21

\section{4}

sterk dalend 37

$$
\text { - }
$$

sterk stijgend

constant 29

constant 23

sterk stijgend 21

-.

stijgend

20

constant

-

dalend

constant

constant

constant stijgend

sterk stijgend

stijgend

sterk stijgend constant

sterk stijgend constant constant sterk stijgend sterk stijgend constant sterk stijgend

sterk dalend constant 17 sterk dalend 22 constant dalend$$
\text { - }
$$$$
\text { constant }
$$

constant constant sterk stijgend sterk dalend constant

$-$

-

constant 
Tabel 2.4 (vervolg)

Percentage jongeren (15-29 jaar) en ouderen (50-64 jaar) per beroepsgroep, gemiddelde 1995-1996

Beroepsgroep

jongeren

$\%$ trend $\quad \%$

1992-'96 trend

1992-'96
Hoofden technische dienst

Werktuigbouwkundigen

Bouwvakkers

Aannemers en installateurs

Architecten en bouwkundig projectleiders

Weg- en waterbouwkundigen

Weg- en waterbouwkundige arbeiders

Weg-en waterbouwkundige vakkrachten

Weg- en waterbouwkundig ontwerpers en projectleiders

Metaalarbeiders

Bankwerkers en lassers

Bedrijfshoofden metaalbewerking

Assembleurs

Monteurs

Werktuigbouwkundig ontwerpers en hoofden

technische dienst

Elektronicamonteurs

Monteurs en controleurs elektrotechnische producten

Elektromonteurs

Elektrotechnisch ontwerpers en bedrijfshoofden

Elektrotechnici

Grafisch productiepersoneel

Grafische vakkrachten

Mechanisch operators

Procesoperators

Procestechnologen

Materiaalkundigen

Confectie-arbeiders

Schoen- en kleermakers

\section{TRANSPORTBEROEPEN}

Laders en lossers

Chauffeurs

Schippers en conducteurs

Vliegers, scheepskapiteins en leidinggevenden

transport

Stewards

\section{MEDISCHE EN PARAMEDISCHE BEROEPEN}

Verpleeghulpen en leerling-verpleegkundigen

Verplegenden en doktersassistenten

Therapeuten en verpleegkundigen

Artsen

Apothekersassistenten en medisch laboranten

Medisch analisten

Apothekers

Afdelingshoofden zorginstelling

\section{ECONOMISCH-ADMINISTRATIEVE BEROEPEN}

Kantoorhulpen, inpakkers en colporteurs

Ondersteunende administratieve hulpkrachten

Bedrijfshoofden

\begin{tabular}{lrll} 
sterk dalend & 22 & constant \\
- & - & - \\
constant & 13 & stijgend \\
constant & 18 & stijgend \\
stijgend & 24 & stijgend \\
- & 24 & stijgend \\
stijgend & 15 & - \\
dalend & 19 & stijgend \\
sterk stijgend & - & - \\
dalend & 14 & stijgend \\
dalend & 15 & constant \\
sterk stijgend & - & sterk stijgend \\
stijgend & 13 & constant \\
constant & 14 & constant \\
& & \\
constant & 22 & - \\
constant & - & constant \\
constant & - & - \\
dalend & 13 & constant \\
sterk dalend & 24 & sterk stijgend \\
stijgend & - & - \\
constant & 11 & - \\
- & 17 & stijgend \\
constant & 12 & - \\
dalend & 14 & stijgend \\
constant & 24 & sterk stijgend \\
constant & 20 & stijgend \\
dalend & 14 & constant \\
dalend & - & stijgend \\
\hline
\end{tabular}

42

25

constant 11

dalend

dalend

17

22

stijgend

constant

dalend

dalend

17 sterk stijgend sterk stijgend sterk stijgend constant constant constant sterk stijgend

$\begin{array}{lr}\text { stijgend } & 14 \\ \text { constant } & - \\ \text { dalend } & 22\end{array}$

constant sterk dalend constant 
Tabel 2.4 (vervolg)

Percentage jongeren (15-29 jaar) en ouderen (50-64 jaar) per beroepsgroep, gemiddelde 1995-1996

\begin{tabular}{lrrrr}
\hline Beroepsgroep & jongeren & ouderen & \\
$\%$ & trend $\begin{array}{c}\% \\
1992-' 96\end{array}$ & $\begin{array}{c}\text { trend } \\
1992-' 96\end{array}$ \\
\hline
\end{tabular}

\section{Economen}

Productieplanners

Organisatie-adviseurs

Organisatiedeskundigen

Receptionisten en administratieve employés

Boekhouders en secretaresses

Assistent accountants

Accountants

Verzekeringsagenten

Commercieel employés

Commercieel medewerkers

Technisch-commercieel employés

Technisch-bedrijfskundig medewerkers

Juridisch en fiscaal medewerkers

Juridisch, bestuurlijk medewerkers

Juristen

Administratieve transportemployés

Leidinggevenden

Managers

Medisch secretaresses

\section{INFORMATICABEROEPEN}

\section{Programmeurs}

Systeemanalisten

Informatici

Technisch systeemanalisten

\section{SOCIAAL-CULTURELE BEROEPEN}

Activiteitenbegeleiders en medewerkers

arbeidsbemiddeling

Sociaal-cultureel werkers

Sociale raadslieden en hoofden personeelszaken

Sociaal-wetenschappelijk medewerkers

Sociaal-wetenschappelijk onderzoekers

\section{VERZORGENDE EN DIENSTVERLENENDE BEROEPEN}

22
27

21

21

30

31

26

21

32

32

18

30

17

-

16

24

6

$\begin{array}{lr}\text { constant } & - \\ \text { dalend } & 13 \\ \text { constant } & 17 \\ \text { sterk stijgend } & - \\ \text { dalend } & 15 \\ \text { dalend } & 13 \\ \text { dalend } & 15 \\ \text { constant } & 14 \\ \text { dalend } & 9 \\ \text { dalend } & 14 \\ \text { dalend } & 19 \\ \text { stijgend } & 18 \\ \text { constant } & - \\ \text { dalend } & 12 \\ \text { constant } & 22 \\ \text { dalend } & 15 \\ \text { dalend } & 17 \\ \text { - } & 29 \\ \text { constant } & 33 \\ \text { sterk dalend } & 15\end{array}$

sterk dalend 7

- 6

stijgend

constant stijgend

sterk stijgend

sterk dalend

stijgend

stijgend

stijgend

-

constant

constant

constant

constant

constant

stijgend

constant

stijgend

constant

constant

stijgend

sterk stijgend

sterk stijgend

sterk stijgend

-

sterk dalend

\author{
Vakkenvullers \\ Interieurverzorgers \\ Verkopers \\ Winkeliers \\ Hulpkrachten horeca en verzorging \\ Ziekenverzorgenden \\ Verzorgend personeel \\ Café- en snackbarhouders \\ Bedrijfshoofden horeca \\ Bakkers en slagers
}

$\begin{array}{lr}\text { stijgend } & - \\ \text { stijgend } & 16 \\ \text { constant } & 9 \\ \text { constant } & 20 \\ \text { constant } & 13 \\ \text { dalend } & 4 \\ \text { dalend } & 9 \\ \text { - } & 25 \\ \text { constant } & 19 \\ \text { constant } & 22\end{array}$

sterk dalend constant constant constant constant sterk stijgend stijgend sterk stijgend sterk stijgend 
Tabel 2.4 (vervolg)

Percentage jongeren (15-29 jaar) en ouderen (50-64 jaar) per beroepsgroep, gemiddelde 1995-1996

\begin{tabular}{lrrrr}
\hline Beroepsgroep & jongeren & ouderen & trend \\
& $\%$ & trend & trend \\
$1992-' 96$
\end{tabular}

\section{OPENBARE ORDE- EN VEILIGHEIDSBEROEPEN}

Aspirant politieagenten, soldaten en beveiligingshulpkrachten 48

Politieagenten, onderofficieren en beveiligingsemployés 20

Politie-inspecteurs en officieren

Brandweerlieden

$\begin{array}{lll}\begin{array}{l}\text { constant } \\ \text { dalend }\end{array} & 9 & \begin{array}{l}\text { sterk dalend } \\ \text { constant } \\ \text { sterk dalend }\end{array} \\ \begin{array}{lll}\text { sterk stijgend } \\ \text { constant }\end{array} \\ \text { dalend } & - & \text { constant }\end{array}$

Totaal

29

dalend

constant

Bron: CBS/ROA 


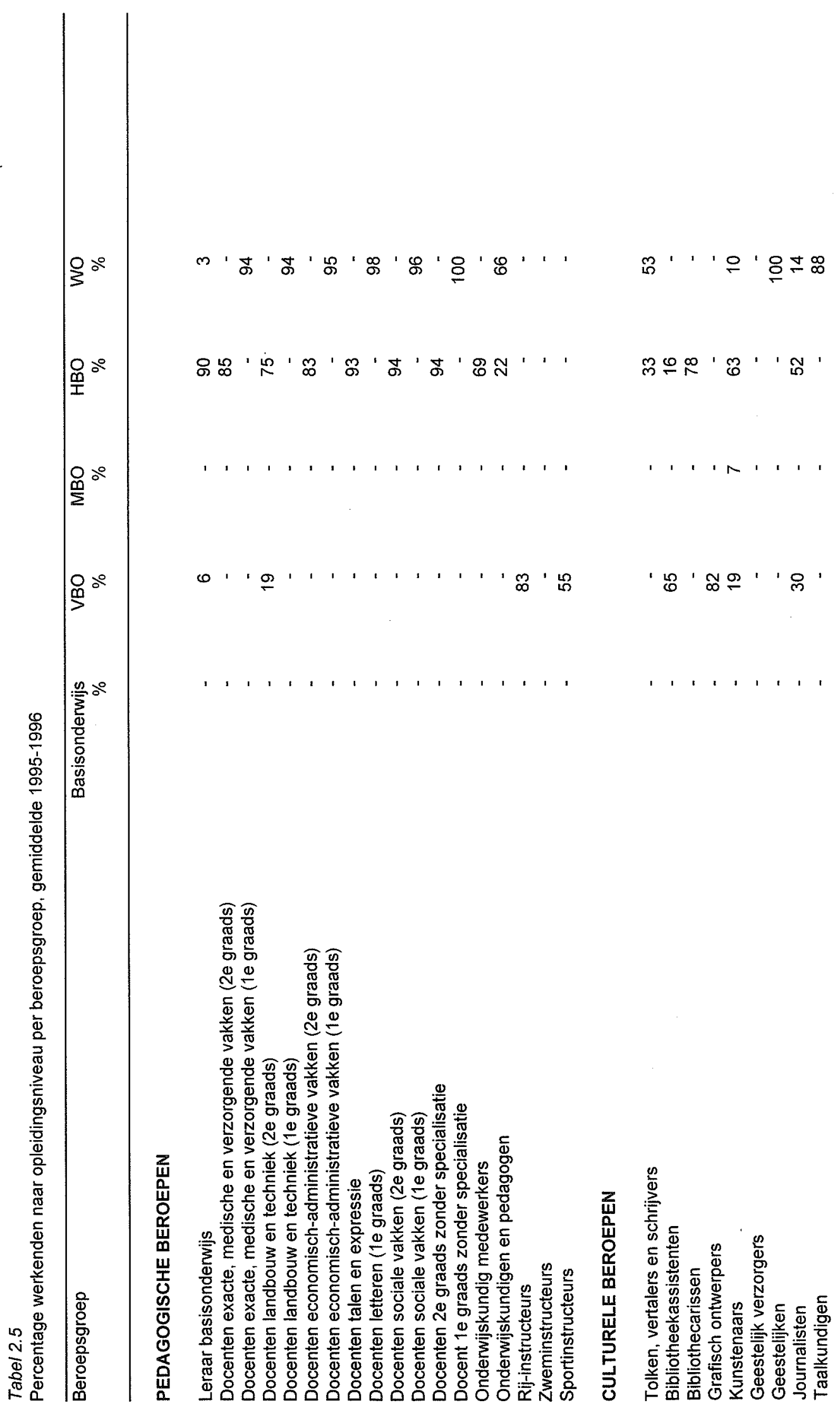




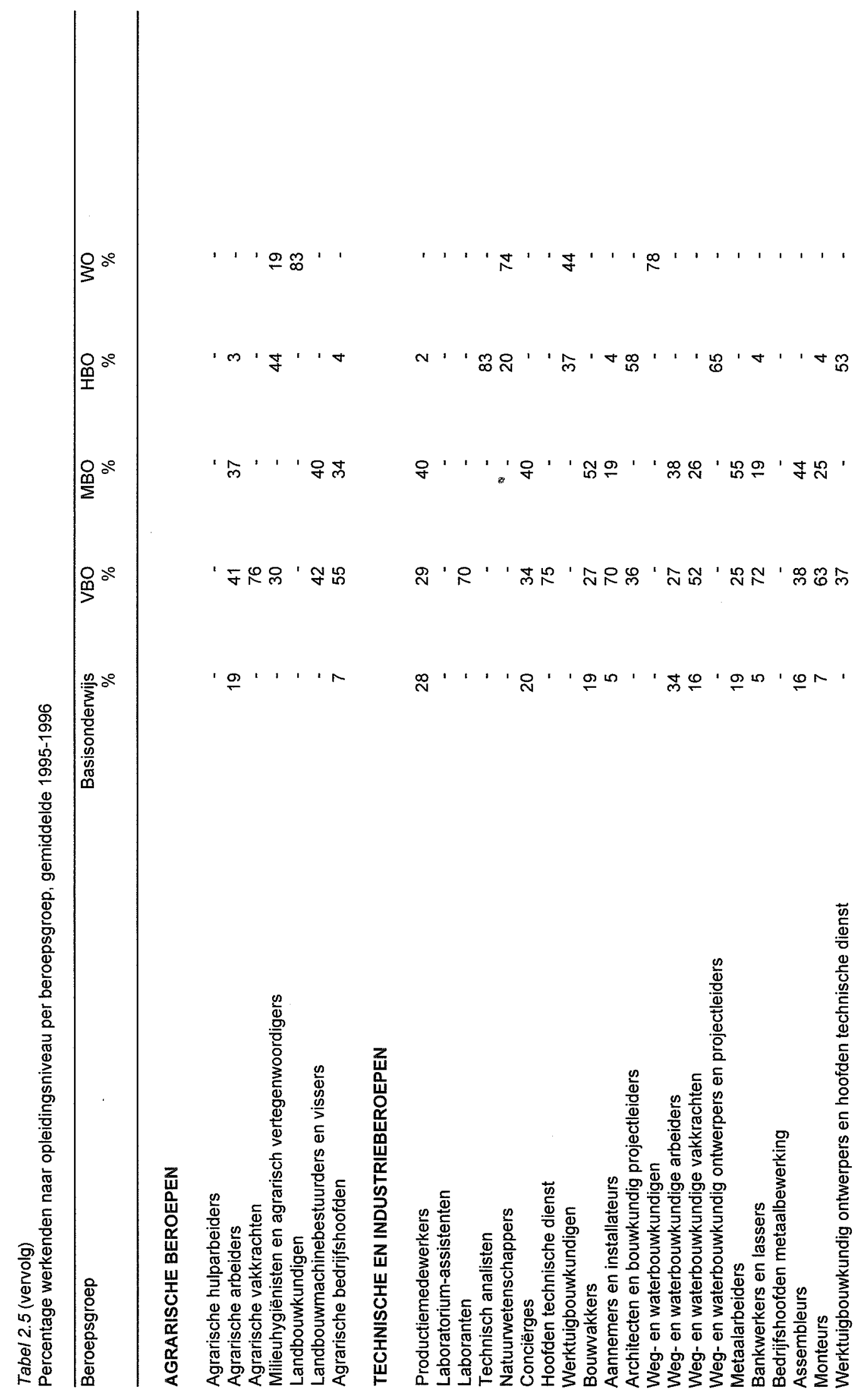




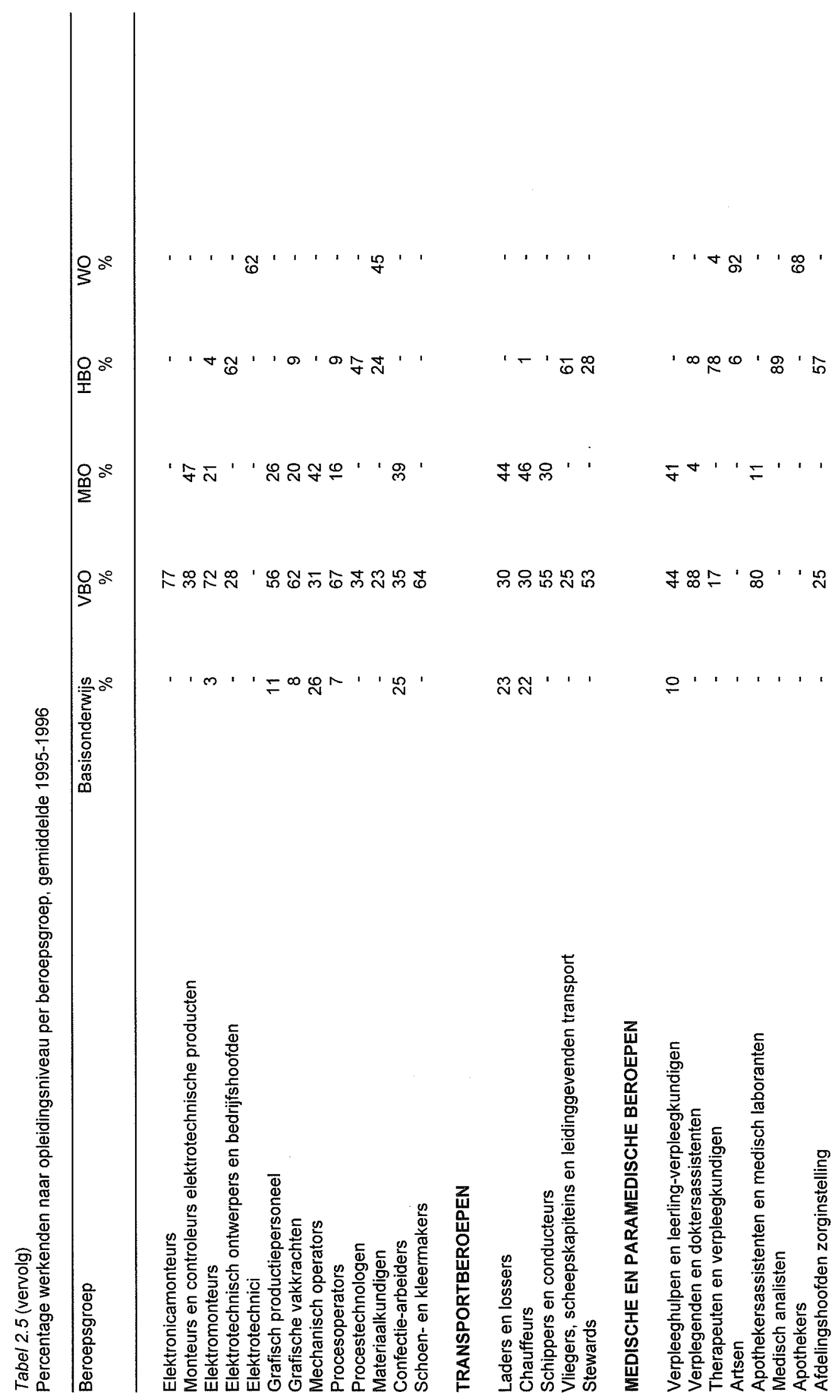




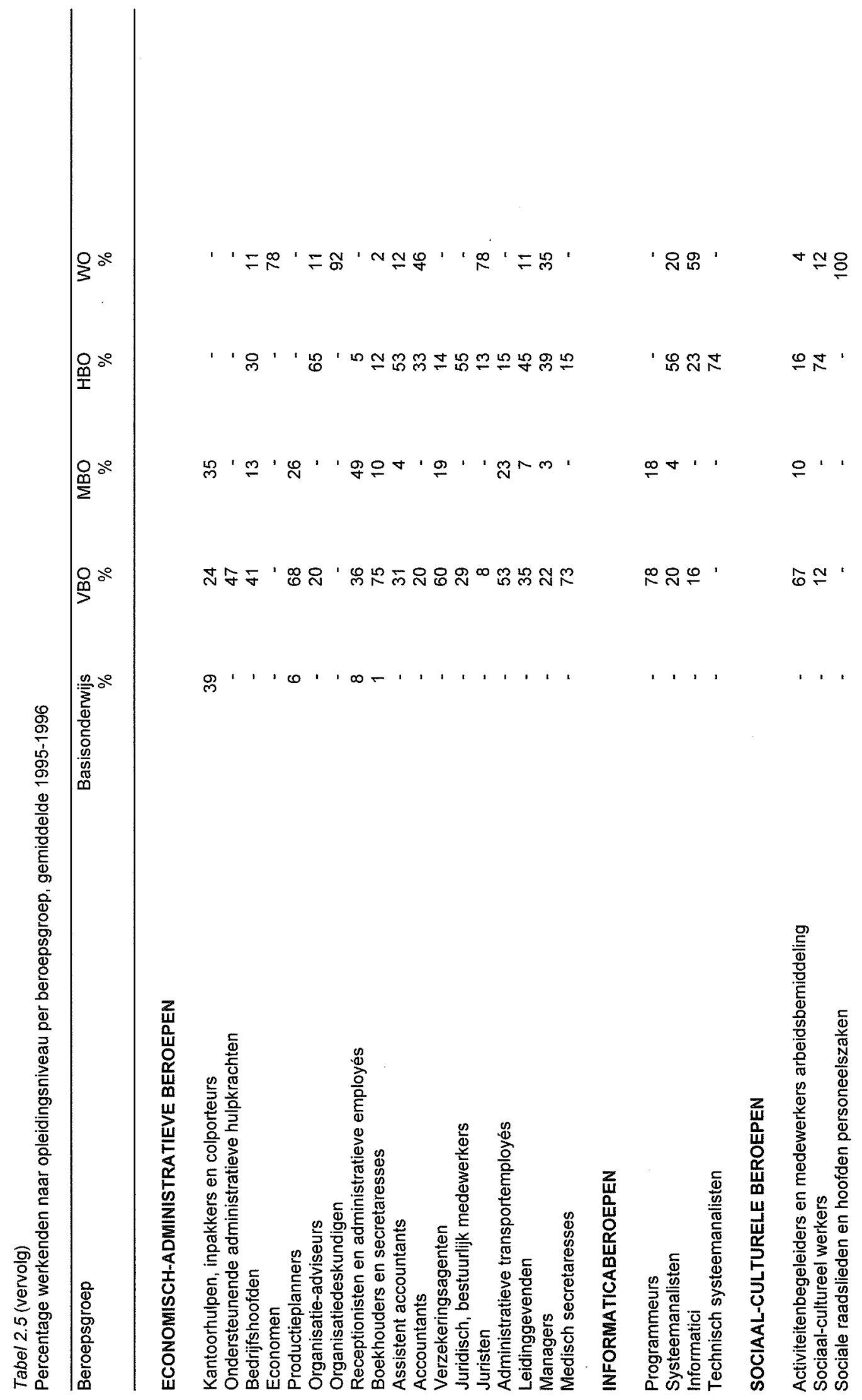




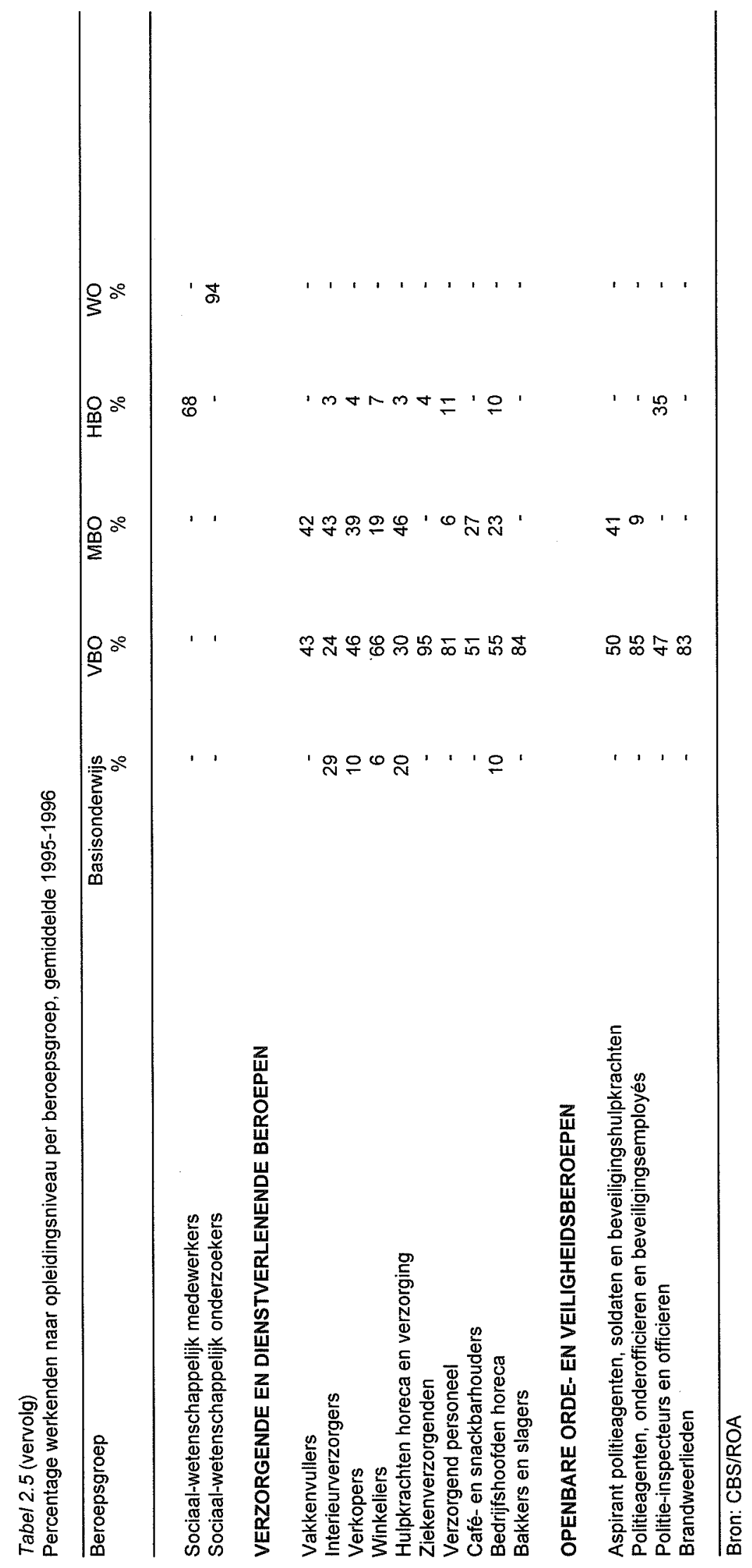


Tabe/ 2.6

Deeltijdarbeid per beroepsgroep, gemiddelde 1995-1996

\begin{tabular}{llll}
\hline Beroepsgroep & $\%$ & typering & $\begin{array}{l}\text { gemiddeld aantal } \\
\text { uren per week }\end{array}$
\end{tabular}

\section{PEDAGOGISCHE BEROEPEN}

Leraar basisonderwijs

Docenten exacte, medische en verzorgende vakken

(2e graads)

Docenten exacte, medische en verzorgende vakken

(1e graads)

Docenten landbouw en techniek ( $2 e$ graads)

Docenten landbouw en techniek (1e graads)

Docenten economisch-administratieve vakken (2e graads) 30

Docenten economisch-administratieve vakken (1e graads) -

Docenten talen en expressie

Docenten letteren (1e graads)

Docenten sociale vakken (2e graads)

Docenten sociale vakken (1e graads)

Docenten $2 e$ graads zonder specialisatie

Docent 1 e graads zonder specialisatie

Onderwijskundig medewerkers

Onderwijskundigen en pedagogen

Rij-instructeurs

Zweminstructeurs

Sportinstructeurs

$\begin{array}{rll}35 & \text { stijgend } & 34 \\ 39 & \text { dalend } & 34 \\ & & \\ 31 & \text { constant } & 35 \\ 18 & \text { constant } & 37 \\ - & \text { sterk stijgend } & 38 \\ 30 & \text { constant } & 35 \\ - & \text { stijgend } & 38 \\ 55 & \text { constant } & 31 \\ 45 & \text { stijgend } & 34 \\ 29 & \text { constant } & 37 \\ 44 & \text { stijgend } & 33 \\ 31 & - & 36 \\ - & - & 38 \\ 34 & \text { dalend } & 36 \\ 42 & - & 35 \\ - & \text { - } & 41 \\ 56 & \text { sterk stijgend } & 30 \\ 43 & \text { stijgend } & 36\end{array}$

\section{CULTURELE BEROEPEN}

Tolken, vertalers en schrijvers

Bibliotheekassistenten

Bibliothecarissen

Grafisch ontwerpers

Kunstenaars

Geestelijk verzorgers

Geestelijken

Journalisten

Taalkundigen

$\begin{array}{ll}\text { constant } & 36 \\ \text { constant } & 32 \\ - & 32 \\ - & 43 \\ - & 39 \\ - & - \\ - & 41 \\ \text { stijgend } & 36 \\ \text { stijgend } & 35\end{array}$

\section{AGRARISCHE BEROEPEN}

Agrarische hulparbeiders

Agrarische arbeiders

Agrarische vakkrachten

Milieuhygiënisten en agrarisch vertegenwoordigers

constant

Landbouwkundigen

Landbouwmachinebestuurders en vissers

Agrarische bedrijfshoofden

$-$

sterk stijgend

\section{TECHNISCHE EN INDUSTRIEBEROEPEN}

\author{
Productiemedewerkers \\ Laboratorium-assistenten \\ Laboranten \\ Technisch analisten \\ Natuurwetenschappers \\ Conciërges \\ Hoofden technische dienst \\ Werktuigbouwkundigen \\ Bouwvakkers
}

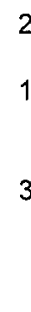

$\begin{array}{ll}\text { stijgend } & 36 \\ - & 36 \\ \text { stijgend } & 37 \\ \text { sterk stijgend } & 36 \\ \text { dalend } & 38 \\ \text { stijgend } & 35 \\ \text { constant } & 40 \\ - & 40 \\ \text { stijgend } & 40\end{array}$




\begin{tabular}{llll}
\hline Beroepsgroep & $\%$ & typering & $\begin{array}{l}\text { gemiddeld aantal } \\
\text { uren per week }\end{array}$
\end{tabular}

Aannemers en installateurs

Architecten en bouwkundig projectleiders

sterk stijgend $\quad 41$

stijgend $\quad 40$

Weg- en waterbouwkundigen

Weg-en waterbouwkundige arbeiders

Weg- en waterbouwkundige vakkrachten

Weg- en waterbouwkundig ontwerpers en projectleiders

Metaalarbeiders

Bankwerkers en lassers

Bedrijfshoofden metaalbewerking

Assembleurs

Monteurs

Werktuigbouwkundig ontwerpers en hoofden technische dienst-

Elektronicamonteurs

Monteurs en controleurs elektrotechnische producten

Elektromonteurs

Elektrotechnisch ontwerpers en bedrijfshoofden

Elektrotechnici

Grafisch productiepersoneel

- 40

sterk stijgend $\quad 40$

- 41

- 40

constant $\quad 39$

stijgend $\quad 39$

sterk stijgend 43

- 41

constant $\quad 40$

sterk stijgend 41

sterk stijgend 39

stijgend $\quad 38$

constant $\quad 40$

constant $\quad 40$

- 40

constant $\quad 37$

stijgend $\quad 40$

sterk stijgend 38

- 38

constant 41

sterk dalend 41

dalend $\quad 36$

sterk dalend $\quad 44$

TRANSPORTBEROEPEN

Laders en lossers $\quad 17$

Chauffeurs 10

Schippers en conducteurs

Vliegers, scheepskapiteins en leidinggevenden transport

Stewards

$-$

stijgend $\quad 37$

stijgend $\quad 40$

- 42

sterk stijgend 41

constant 33

\section{MEDISCHE EN PARAMEDISCHE BEROEPEN}

Verpleeghulpen en leerling-verpleegkundigen 38

Verplegenden en doktersassistenten $\quad 59$

Therapeuten en verpleegkundigen $\quad 55$

Artsen

Apothekersassistenten en medisch laboranten $\quad 44$

Medisch analisten $\quad 43$

Apothekers

Afdelingshoofden zorginstelling

sterk stijgend 33

stijgend $\quad 30$

stijgend $\quad 32$

- 43

stijgend $\quad 33$

constant $\quad 32$

$-\quad 41$

\section{ECONOMISCH-ADMINISTRATIEVE BEROEPEN}

Kantoorhulpen, inpakkers en colporteurs

Ondersteunende administratieve hulpkrachten $\quad 65$

Bedrijfshoofden 13

Economen 16

Productieplanners $\quad 12$

Organisatie-adviseurs $\quad 15$

Organisatiedeskundigen 15

Receptionisten en administratieve employés $\quad 47$

Boekhouders en secretaresses

$\begin{array}{ll}\text { stijgend } & 34 \\ \text { constant } & 26 \\ \text { sterk stijgend } & 45 \\ \text { stijgend } & 38 \\ \text { stijgend } & 38 \\ \text { sterk stijgend } & 39 \\ \text { constant } & 40 \\ \text { constant } & 31 \\ \text { stijgend } & 34\end{array}$


Tabel 2.6 (vervolg)

Deeltijdarbeid per beroepsgroep, gemiddelde 1995-1996

\begin{tabular}{llll}
\hline Beroepsgroep & $\%$ & typering & $\begin{array}{l}\text { gemiddeld aantal } \\
\text { uren per week }\end{array}$
\end{tabular}

Assistent accountants

Accountants

Verzekeringsagenten

stijgend $\quad 39$

Commercieel employés

constant $\quad 40$

stijgend $\quad 34$

Commercieel medewerkers

stijgend

37

Technisch-commercieel employés

Technisch-bedrijfskundig medewerkers

sterk stijgend 44

Juridisch en fiscaal medewerkers

$$
\text { - } 40
$$

sterk stijgend 40

Juridisch, bestuurlijk medewerkers

stijgend

38

Juristen

Administratieve transportemployés$$
\text { - } 38
$$

stijgend $\quad 39$

sterk dalend 42

Leidinggevenden

Managers

-

sterk stijgend 40

Medisch secretaresses

stijgend

29

\section{INFORMATICA BEROEPEN}

Programmeurs

Systeemanalisten

Informatici

Technisch systeemanalisten

$\begin{array}{ll}\text { constant } & 39 \\ - & 39 \\ \text { - } & 41 \\ \text { sterk stijgend } & 39\end{array}$

$\begin{array}{ll}\text { stijgend } & 32 \\ \text { constant } & 34 \\ \text { constant } & 33 \\ \text { - } & 36 \\ \text { stijgend } & 35\end{array}$

Activiteitenbegeleiders en medewerkers arbeidsbemiddeling 46

Sociaal-cultureel werkers

Sociaal-wetenschappelijk medewerkers

Sociaal-wetenschappelijk onderzoekers

40

\section{VERZORGENDE EN DIENSTVERLENENDE BEROEPEN}

\author{
Vakkenvullers \\ Interieurverzorgers \\ Verkopers \\ Winkeliers \\ Hulpkrachten horeca en verzorging \\ Ziekenverzorgenden \\ Verzorgend personeel \\ Café- en snackbarhouders \\ Bedrijfshoofden horeca \\ Bakkers en slagers
}

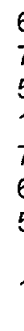

70

57

14

72

68

59

$-$

14

\section{OPENBARE ORDE EN VEILIGHEIDSBEROEPEN}

Aspirant politieagenten, soldaten en beveiligingshulpkrachten13 Politieagenten, onderofficieren en beveiligingsemployés

Politie-inspecteurs en officieren

Brandweerlieden

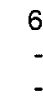

Totaal

$\begin{array}{ll}\text { - } & 26 \\ \text { constant } & 26 \\ \text { stijgend } & 30 \\ \text { stijgend } & 45 \\ \text { constant } & 26 \\ \text { constant } & 28 \\ \text { stijgend } & 30 \\ \text { - } & 58 \\ \text { - } & 50 \\ \text { sterk stijgend } & 49\end{array}$

sterk stijgend 38

sterk stijgend 38

39

46

stijgend $\quad 37$

\section{Bron: ROA/CBS}

\section{Toelichting:}

Deeltijdarbeid betreft personen die hoogstens 38 uur maar minstens 12 uur per week werkzaam zijn. 
Tabel 2.7

Flexibel en vast werk per beroepsgroep, gemiddelde 1995-1996

\begin{tabular}{lllll}
\hline Beroepsgroep & Flexibel & trend & Vast & trend \\
& werk \% & $1992-' 96$ & werk \% & $1992-96$ \\
\hline
\end{tabular}

\section{PEDAGOGISCHE BEROEPEN}

Leraar basisonderwijs

Docenten exacte, medische en verzorgende vakken (2e graads)

Docenten exacte, medische en verzorgende vakken (1e graads)

Docenten landbouw en techniek (2e graads)

Docenten landbouw en techniek (1e graads)

Docenten economisch-administratieve vakken

( $2 \mathrm{e}$ en $3 \mathrm{e} \mathrm{gr}$.)

Docenten economisch-administratieve vakken

(1e gr. en WO)

Docenten talen en expressie

Docenten letteren (1e graads)

Docenten sociale vakken (2e graads)

Docenten sociale vakken (1e graads)

Docenten $2 e$ graads zonder specialisatie

Docent 1e graads zonder specialisatie

Onderwijskundig medewerkers

Onderwijskundigen en pedagogen

Rij-instructeurs

Zweminstructeurs

Sportinstructeurs

\section{CULTURELE BEROEPEN}

Tolken, vertalers en schrijvers

Bibliotheekassistenten

Bibliothecarissen

Grafisch ontwerpers

Kunstenaars

Geestelijk verzorgers

Geestelijken

Journalisten

Taalkundigen

\section{AGRARISCHE BEROEPEN}

Agrarische hulparbeiders

Agrarische arbeiders

Agrarische vakkrachten

Milieuhygiënisten en agrarisch vertegenwoordigers

Landbouwkundigen

Landbouwmachinebestuurders en vissers

Agrarische bedrijfshoofden

\section{TECHNISCHE EN INDUSTRIEBEROEPEN}

Productiemedewerkers

Laboratorium-assistenten

Laboranten

Technisch analisten

Natuurwetenschappers

Conciërges

Hoofden technische dienst

$\begin{array}{lll}\text { stijgend } & 93 & \text { constant } \\ \text { constant } & 97 & \text { constant } \\ & & \\ \text { sterk dalend } & 97 & \begin{array}{l}\text { constant } \\ \text { constant }\end{array} \\ \text { - } & 100 & \text { constant } \\ & & \\ \text { - } & 94 & \text { constant } \\ & & \\ \text { sterk dalend } & 100 & \text { constant } \\ \text { constant } & 94 & \text { constant } \\ \text { - } & 96 & \text { constant } \\ \text { - } & 96 & \text { constant } \\ \text { - } & 92 & \text { constant } \\ \text { sterk stijgend } & 96 & \text { constant } \\ \text { - } & 100 & \text { constant } \\ \text { - } & 100 & \text { constant } \\ \text { - } & 94 & \text { constant } \\ \text { - } & 71 & \text { constant } \\ \text { - } & 78 & \text { constant } \\ \text { - } & 89 & \text { constant }\end{array}$

$\begin{array}{lll}\text { constant } & 71 & \text { dalend } \\ \text { sterk stijgend } & 91 & \text { constant } \\ \text { sterk stijgend } & 96 & \text { constant } \\ \text { - } & 100 & \text { constant } \\ \text { - } & 84 & \text { dalend } \\ - & - & - \\ - & 100 & \text { constant } \\ \text { sterk stijgend } & 88 & \text { dalend } \\ \text { - } & 88 & \text { constant }\end{array}$

sterk stijgend sterk stijgend sterk stijgend

dalend constant dalend 96 constant 100 constant 83 stijgend 92 stijgend

sterk stijgend sterk stijgend 85

dalend constant constant constant constant constant constant 


\begin{tabular}{llllll}
\hline Beroepsgroep & - & Flexibel & trend & Vast & trend \\
& werk \% & $1992-' 96$ & werk \% & $1992-' 96$ \\
& & &
\end{tabular}

\section{Werktuigbouwkundigen}

Bouwvakkers

Aannemers en instaliateurs

Architecten en bouwkundig projectleiders

Weg-en waterbouwkundigen

Weg-en waterbouwkundige arbeiders

Weg- en waterbouwkundige vakkrachten

Weg- en waterbouwkundig ontwerpers en projectleiders

Metaalarbeiders

Bankwerkers en lassers

Bedrijfshoofden metaalbewerking

Assembleurs

Monteurs

Werktuigbouwkundig ontwerpers en hoofden technische dienst

Elektronicamonteurs

Monteurs en controleurs elektrotechnische producten

Elektromonteurs

Elektrotechnisch ontwerpers en bedrijfshoofden

Elektrotechnici

Grafisch productiepersoneel

Grafische vakkrachten

Mechanisch operators

Procesoperators

Procestechnologen

Materiaalkundigen

Confectie-arbeiders

Schoen- en kleermakers

\section{TRANSPORTBEROEPEN}

Laders en lossers

Chauffeurs

Schippers en conducteurs

Vliegers, scheepskapiteins en leidinggevenden transport Stewards

\section{MEDISCHE EN PARAMEDISCHE BEROEPEN}

Verpleeghulpen en leerling-verpleegkundigen

Verplegenden en doktersassistenten

Therapeuten en verpleegkundigen

Artsen

Apothekersassistenten en medisch laboranten

Medisch analisten

Apothekers

Afdelingshoofden zorginstelling

\section{ECONOMISCH-ADMINISTRATIEVE BEROEPEN}

Kantoorhulpen, inpakkers en colporteurs

Ondersteunende administratieve hulpkrachten

Bedrijfshoofden

Economen

Productieplanners

$\begin{array}{lll} & 95 & \text { constant } \\ \text { sterk stijgend } & 94 & \text { constant } \\ \text { sterk stijgend } & 97 & \text { constant } \\ \text { sterk stijgend } & 96 & \text { constant } \\ \text { - } & 100 & \text { constant } \\ \text { - } & 96 & \text { constant } \\ \text { sterk dalend } & 97 & \text { constant } \\ \text { - } & 94 & \text { constant } \\ \text { sterk stijgend } & 91 & \text { constant } \\ \text { sterk stijgend } & 94 & \text { constant } \\ \text { - } & 100 & \text { constant } \\ \text { sterk stijgend } & 88 & \text { dalend } \\ \text { sterk stijgend } & 97 & \text { constant } \\ & & \\ \text { - } & 96 & \text { constant } \\ \text { sterk stijgend } & 96 & \text { constant } \\ \text { sterk stijgend } & 88 & \text { dalend } \\ \text { sterk stijgend } & 94 & \text { constant } \\ \text { - } & 95 & \text { constant } \\ \text { sterk stijgend } & 100 & \text { constant } \\ \text { sterk stijgend } & 93 & \text { constant } \\ \text { sterk stijgend } & 97 & \text { constant } \\ \text { sterk stijgend } & 91 & \text { constant } \\ \text { - } & 98 & \text { constant } \\ \text { sterk stijgend } & 100 & \text { constant } \\ \text { - } & 96 & \text { constant } \\ \text { - } & 89 & \text { constant } \\ \text { - } & 83 & \text { dalend }\end{array}$

sterk stijgend 83 sterk stijgend 92

- 97

sterk stijgend 96

sterk stijgend 84

dalend

constant

constant

constant

constant

$\begin{array}{lll}\text { - } & 92 & \text { constant } \\ \text { constant } & 92 & \text { constant } \\ \text { stijgend } & 89 & \text { constant } \\ \text { sterk stijgend } & 95 & \text { constant } \\ \text { sterk stijgend } & 97 & \text { constant } \\ - & 97 & \text { constant } \\ - & 100 & \text { constant } \\ - & 100 & \text { constant }\end{array}$

$\begin{array}{llll}21 & \text { sterk stijgend } & 76 & \text { dalend } \\ 32 & - & 64 & \text { stijgend }\end{array}$

$\begin{array}{llll}32 & - & - & \end{array}$

- $\quad$ - $\quad 93$ constant

- constant 98 constant 
Organisatie-adviseurs

Organisatiedeskundigen

Receptionisten en administratieve employés

Boekhouders en secretaresses

Assistent accountants

Accountants

Verzekeringsagenten

Commercieel employés

Commercieel medewerkers

Technisch-commercieel employés

Technisch-bedrijfskundig medewerkers

Juridisch en fiscaal medewerkers

Juridisch, bestuurlijk medewerkers

Juristen

Administratieve transportemployés

Leidinggevenden

Managers

Medisch secretaresses

\section{INFORMATICA BEROEPEN}

Programmeurs

Systeemanalisten

Informatici

Technisch systeemanalisten

$\begin{array}{ll}\text { - } & 96 \\ \text { sterk stijgend } & 96 \\ \text { sterk stijgend } & 89 \\ \text { sterk stijgend } & 94 \\ \text { sterk stijgend } & 97 \\ \text { - } & 100 \\ \text { sterk stijgend } & 90 \\ \text { sterk stijgend } & 94 \\ \text { sterk stijgend } & 98 \\ \text { sterk stijgend } & 100 \\ \text { sterk stijgend } & 96 \\ \text { sterk stijgend } & 99 \\ \text { - } & 97 \\ \text { sterk stijgend } & 98 \\ \text { sterk stijgend } & 96 \\ \text { - } & 100 \\ \text { sterk stijgend } & 99 \\ \text { sterk stijgend } & 94\end{array}$

dalend constant constant constant constant constant constant constant constant constant constant constant constant constant constant constant constant constant

constant constant constant constant

\section{SOCIAAL-CULTURELE BEROEPEN}

Activiteitenbegeleiders en medewerkers arbeids-

bemiddeling

sterk stijgend 90

constant

Sociaal-cultureel werkers sterk stijgend 94

constant

Sociale raadslieden en hoofden personeelszaken

Sociaal-wetenschappelijk medewerkers

Sociaal-wetenschappelijk onderzoekers

sterk dalend 108

constant

constant

sterk stijgend 100

constant

\section{VERZORGENDE EN DIENSTVERLENENDE BEROEPEN}

\author{
Vakkenvullers \\ Interieurverzorgers \\ Verkopers \\ Winkeliers \\ Hulpkrachten horeca en verzorging \\ Ziekenverzorgenden \\ Verzorgend personeel \\ Café- en snackbarhouders \\ Bedrijfshoofden horeca \\ Bakkers en slagers
}

\section{OPENBARE ORDE- EN VEILIGHEIDSBEROEPEN}

Aspirant politieagenten, soldaten en beveiligingshulpkrachten

Politieagenten, onderofficieren en beveiligingsemployés

Politie-inspecteurs en officieren

Brandweerlieden

$\begin{array}{ll}\text { sterk stijgend } & 64 \\ \text { sterk stijgend } & 80 \\ \text { stijgend } & 86 \\ \text { sterk stijgend } & 98 \\ \text { sterk stijgend } & 78 \\ \text { - } & 88 \\ \text { stijgend } & 89 \\ \text { sterk stijgend } & 75 \\ \text { constant } & 94 \\ \text { sterk stijgend } & 93\end{array}$

dalend constant constant constant dalend constant constant constant dalend dalend 
Tabel 2.7 (vervolg)

Flexibel en vast werk per beroepsgroep, gemiddelde 1995-1996

beroepsgroep

Flexibel trend

werk \% 1992-'96

Vast trend

werk \% 1992-'96

Totaal

8

stijgend

91

constant

Bron: ROA/CBS

\section{Toelichting:}

Van een flexibele arbeidsrelatie is sprake bij uitzendkrachten, oproepkrachten, invalskrachten en contracten zonder een vast aantal arbeidsuren en indien geen vast dienstverband is overeengekomen. Een arbeidscontract wordt als niet-vast beschouwd als de contractuele termijn korter is dan een jaar en er geen vooruitzicht is op een vast dienstverband. 


\section{PEDAGOGISCHE BEROEPEN}

Leraar basisonderwijs

Docenten exacte, medische en verzorgende vakken

(2e graads)

Docenten exacte, medische en verzorgende vakken

(1e graads)

Docenten landbouw en techniek (2e graads)

Docenten landbouw en techniek (1e graads)

Docenten economisch-administratieve vakken

(2e en $3 e \mathrm{gr}$.)

Docenten economisch-administratieve vakken

(1e gr. en WO)

Docenten talen en expressie

Docenten letteren (1e graads)

Docenten sociale vakken ( 2 e graads)

Docenten sociale vakken (1e graads)

Docenten 2 e graads zonder specialisatie

Docent 1 e graads zonder specialisatie

Onderwijskundig medewerkers

Onderwijskundigen en pedagogen

Rij-instructeurs

Zweminstructeurs

Sportinstructeurs

\section{CULTURELE BEROEPEN}

Tolken, vertalers en schrijvers

Bibliotheekassistenten

Bibliothecarissen

Grafisch ontwerpers

Kunstenaars

Geestelijk verzorgers

Geestelijken

Journalisten

Taalkundigen

\section{AGRARISCHE BEROEPEN}

Agrarische hulparbeiders

Agrarische arbeiders

Agrarische vakkrachten

Milieuhygiënisten en agrarisch vertegenwoordigers

Landbouwkundigen

Landbouwmachinebestuurders en vissers

Agrarische bedrijfshoofden

\section{TECHNISCHE EN INDUSTRIEBEROEPEN}

Productiemedewerkers

Laboratorium-assistenten

Laboranten

Technisch analisten

Natuurwetenschappers

Conciërges

Hoofden technische dienst

$\begin{array}{lll} & \text { erg laag } & - \\ - & \text { erg laag } & \text { sterk stijgend } \\ & & \\ - & \text { erg laag } & - \\ - & \text { gemiddeld } & \text { constant } \\ - & \text { erg laag } & - \\ & & \\ - & \text { erg laag } & - \\ & & \\ - & \text { erg laag } & - \\ 10 & \text { gemiddeld } & \text { constant } \\ - & \text { erg laag } & \text { sterk stijgend } \\ - & \text { erg laag } & - \\ - & \text { erg laag } & \text { - } \\ - & \text { erg laag } & \text { - } \\ - & \text { erg laag } & - \\ - & \text { laag } & \text { sterk stijgend } \\ 12 & \text { gemiddeld } & - \\ 63 & \text { erg hoog } & \text { constant } \\ - & \text { erg laag } & - \\ 40 & \text { erg hoog } & \text { constant }\end{array}$

60

$-$

45

60

$-$

29 gemiddeld hoog hoog gemiddeld laag

sterk dalend

dalend sterk stijgend

$-$

constant constant

$\begin{array}{ll}\text { erg hoog } & \text { stijgend } \\ \text { erg laag } & - \\ \text { erg laag } & - \\ \text { erg hoog } & - \\ \text { erg hoog } & \text { stijgend } \\ \text { - } & - \\ \text { erg hoog } & - \\ \text { erg hoog } & \text { sterk stijgend } \\ \text { laag } & \text { sterk dalend }\end{array}$

sterk stijgend

erg laag

erg laag

erg laag

erg laag

erg laag

laag
sterk dalend sterk dalend sterk dalend 
Werktuigbouwkundigen

Bouwvakkers

Aannemers en installateurs

Architecten en bouwkundig projectleiders

Weg-en waterbouwkundigen

Weg- en waterbouwkundige arbeiders

Weg- en waterbouwkundige vakkrachten

Weg- en waterbouwkundig ontwerpers en projectleiders

Metaalarbeiders

Bankwerkers en lassers

Bedrijfshoofden metaalbewerking

Assembleurs

Monteurs

Werktuigbouwkundig ontwerpers en hoofden technische dienst

Elektronicamonteurs

Monteurs en controleurs elektrotechnische producten

Elektromonteurs

Elektrotechnisch ontwerpers en bedrijfshoofden

Elektrotechnici

Grafisch productiepersoneel

Grafische vakkrachten

Mechanisch operators

Procesoperators

Procestechnologen

Materiaalkundigen

Confectie-arbeiders

Schoen- en kleermakers

\section{laag}

gemiddeld

hoog

hoog

hoog

gemiddeld

gemiddeld

erg laag

erg laag

laag

hoog

hoog

gemiddeld

gemiddeld

erg laag

laag

laag

erg laag

laag

gemiddeld

hoog

erg laag

erg laag

hoog

hoog

gemiddeld

erg hoog

\section{erg laag}

laag

laag

gemiddeld

erg laag
Laders en lossers

Schippers en conducteurs

Vliegers, scheepskapiteins en leidinggevenden transport Stewards

\section{MEDISCHE EN PARAMEDISCHE BEROEPEN}

Verpleeghulpen en leerling-verpleegkundigen

Verplegenden en doktersassistenten

Therapeuten en verpleegkundigen

Artsen

Apothekersassistenten en medisch laboranten

Medisch analisten

Apothekers

Afdelingshoofden zorginstelling

\section{ECONOMISCH-ADMINISTRATIEVE BEROEPEN}

Kantoorhulpen, inpakkers en colporteurs

Ondersteunende administratieve hulpkrachten

Bedrijfshoofden

Economen

Productieplanners

Organisatie-adviseurs

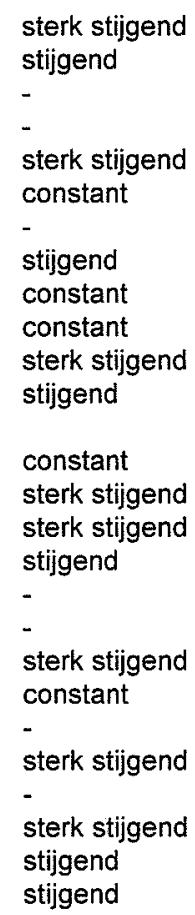

sterk stijgend stiigend

-

-

-

$\begin{array}{ll}\text { erg laag } & - \\ \text { erg laag } & - \\ \text { hoog } & \text { constant } \\ \text { erg hoog } & \text { dalend } \\ \text { laag } & \text { dalend } \\ \text { erg laag } & - \\ \text { hoog } & - \\ \text { erg laag } & -\end{array}$

$\begin{array}{lll}- & \text { erg laag } & \text { sterk stijgend } \\ - & \text { hoog } & \text { sterk dalend } \\ 59 & \text { erg hoog } & \text { stijgend } \\ - & \text { laag } & - \\ - & \text { erg laag } & - \\ 17 & \text { hoog } & \text { sterk stijgend }\end{array}$


Organisatiedeskundigen

Receptionisten en administratieve employés

Boekhouders en secretaresses

Assistent accountants

Accountants

Verzekeringsagenten

Commercieel employés

Commercieel medewerkers

Technisch-commercieel employés

Technisch-bedrijfskundig medewerkers

Juridisch en fiscaal medewerkers

Juridisch, bestuurlijk medewerkers

Juristen

Administratieve transportemployés

Leidinggevenden

Managers

Medisch secretaresses

\section{INFORMATICA BEROEPEN}

Programmeurs

Systeemanalisten

Informatici

Technisch systeemanalisten

\section{SOCIAAL-CULTURELE BEROEPEN}

Activiteitenbegeleiders en medewerkers arbeids-

bemiddeling

Sociaal-cultureel werkers

Sociale raadslieden en hoofden personeelszaken

Sociaal-wetenschappelijk medewerkers

Sociaal-wetenschappelijk onderzoekers

\section{VERZORGENDE EN DIENSTVERLENENDE BEROEPEN}

\author{
Vakkenvullers \\ Interieurverzorgers \\ Verkopers \\ Winkeliers \\ Hulpkrachten horeca en verzorging \\ Ziekenverzorgenden \\ Verzorgend personeel \\ Café- en snackbarhouders \\ Bedrijfshoofden horeca \\ Bakkers en slagers
}

$\begin{array}{ll}- & \text { erg laag } \\ 6 & \text { laag } \\ 16 & \text { hoog } \\ - & \text { laag }\end{array}$

dalend

stijgend

stijgend

constant

-

stijgend

stijgend

-

sterk stijgend

constant

-

$-$

hoog

gemiddeld

erg laag

sterk stijgend sterk stijgend sterk stijgend constant

$\begin{array}{ll}\text { erg laag } & - \\ \text { erg laag } & \text { constant } \\ \text { erg laag } & - \\ \text { erg laag } & - \\ \text { gemiddeld } & -\end{array}$

erg laag

erg laag

laag

erg hoog

gemiddeld

erg laag

gemiddeld

erg hoog

erg hoog

erg hoog

constant constant constant stijgend sterk stijgend stijgend constant stijgend stijgend

\section{OPENBARE ORDE- EN VEILIGHEIDSBEROEPEN}

Aspirant politieagenten, soldaten en beveiligingshulpkrachten

Politieagenten, onderofficieren en beveiligingsemployés

Politie-inspecteurs en officieren

Brandweerlieden

erg laag

erg laag

erg laag-

erg laag 
Tabel 2.8 (vervolg)

Zelfstandigen per beroepsgroep, gemiddelde 1995-1996

$\% \quad$ typering trend

1992-'96

Totaal $12 \quad$ gemiddeld constant

Bron: CBS/ROA

Toelichting:

Het begrip zelfstandig bevat ook personen die werkzaam zijn in het bedrijf of de praktijk van hun partner of ouders en freelancers e.d. 
Tabel 2.9

Belangrijkste bedrijfssectoren per beroepsgroep, gemiddelde 1995-1996

Beroepsgroep $\quad \% \quad$ trend

\section{PEDAGOGISCHE BEROEPEN}

\section{Leraar basisonderwijs}

Onderwijs

Overheid

Andere bedrijfssectoren

Docenten exacte, medische en verzorgende vakken (2e graads)

Onderwijs

Andere bedrijfssectoren

Docenten exacte, medische en verzorgende vakken (1e graads)

Onderwijs

Andere bedrijfssectoren

Docenten landbouw en techniek (2e graads)

Onderwijs

Andere bedrijfssectoren

Docenten landbouw en techniek (1e graads)

Onderwijs

Andere bedrijfssectoren

Docenten economisch-administratieve vakken (2e graads)

Onderwijs

Andere bedrijfssectoren

Docenten economisch-administratieve vakken (1e graads)

Onderwijs

Andere bedrijfssectoren

\section{Docenten talen en expressie}

Onderwijs

Overige kwartaire diensten

Andere bedrijfssectoren

\section{Docenten letteren (1e graads)}

Onderwijs

Andere bedrijfssectoren

Docenten sociale vakken (2e graads)

Onderwijs

Andere bedrijfssectoren constant

sterk stijgend

-

stijgend

-

15 -

constant

stijgend

-

stijgend

-

stijgend

-

constant

stijgend

sterk dalend

constant

constant 
Tabe/ 2.9 (vervolg)

Belangrijkste bedrijfssectoren per beroepsgroep, gemiddelde 1995-1996

Beroepsgroep $\%$ trend

Docenten sociale vakken (1e graads)

Onderwijs

Andere bedrijfssectoren

Docenten 2 e graads zonder specialisatie

Onderwijs

Andere bedrijfssectoren

\section{Docent 1e graads zonder specialisatie}

Onderwijs

Andere bedrijfssectoren

Onderwijskundig medewerkers

Onderwijs

Andere bedrijfssectoren

Onderwijskundigen en pedagogen

Onderwijs

Gezondheidszorg

Zakelijke dienstverlening

Andere bedrijfssectoren

\section{Rij-instructeurs}

Onderwijs

Andere bedrijfssectoren

Zweminstructeurs

Overige kwartaire diensten

Andere bedrijfssectoren

\section{Sportinstructeurs}

Overige kwartaire diensten

Andere bedrijfssectoren

\section{CULTURELE BEROEPEN}

Tolken, vertalers en schrijvers

Zakelijke dienstverlening

Andere bedrijfssectoren

\section{Bibliotheekassistenten}

Overheid

Overige kwartaire diensten

Andere bedrijfssectoren
96

4

constant

63

constant

constant

constant

-

stijgend

constant stijgend sterk stijgend

-

sterk stijgend

sterk dalend

-

constant

dalend

sterk stijgend 
Tabel 2.9 (vervolg)

Belangrijkste bedrijfssectoren per beroepsgroep, gemiddelde 1995-1996

\begin{tabular}{lll}
\hline Beroepsgroep & $\%$ & trend \\
& & $1994-^{\prime} 96$
\end{tabular}

\section{Bibliothecarissen}

Overige kwartaire diensten

Overheid

Andere bedrijfssectoren

\section{Grafisch ontwerpers}

Zakelijke dienstverlening

constant

Andere bedrijfssectoren

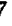

\section{Kunstenaars}

Overige kwartaire diensten

Zakelijke dienstverlening

Andere bedrijfssectoren

\section{Geestelijk verzorgers}

\section{Geestelijken}

Overige kwartaire diensten

\section{Journalisten}

Grafische industrie

Overige commerciële dienstverlening

Overige kwartaire diensten

Andere bedrijfssectoren

\section{Taalkundigen}

Overige kwartaire diensten

Andere bedrijfssectoren

\section{AGRARISCHE BEROEPEN}

\section{Agrarische hulparbeiders}

Tuinbouw

Andere bedrijfssectoren

\section{Agrarische arbeiders}

\author{
Tuinbouw \\ Veehouderij \\ Metaalproducten \\ Overheid \\ Andere bedrijfssectoren
}

constant stijgend stijgend

dalend sterk stijgend stijgend

-

sterk stijgend

sterk stijgend

dalend

constant

dalend 
Tabel 2.9 (vervolg)

Belangrijkste bedrijfssectoren per beroepsgroep, gemiddelde 1995-1996

Beroepsgroep $\%$ trend

1994-'96

\section{Agrarische vakkrachten}

Handel

stijgend

Overheid

constant

Andere bedrijfssectoren

Milieuhygiënisten en agrarisch vertegenwoordigers

Zakelijke dienstverlening

Overheid

Andere bedrijfssectoren

\section{Landbouwkundigen}

\section{Landbouwmachinebestuurders en vissers}

Veehouderij

Akkerbouw, bosbouw en visserii

Andere bedrijfssectoren

\section{Agrarische bedrijfshoofden}

Veehouderij

Tuinbouw

Akkerbouw, bosbouw en visserij

Andere bedrijfssectoren

\section{TECHNISCHE EN INDUSTRIEBEROEPEN}

\section{Productiemedewerkers}

Bouw

Metaalproducten

Elektrotechniek

Overige voedingsproducten

Zakelijke dienstverlening

Handel

Communicatie

Andere bedrijfssectoren

\section{Laboratorium-assistenten}

Diverse bedrijfssectoren

\section{Laboranten}

Eindproducten chemie

Andere bedrijfssectoren

\section{Technisch analisten}

Diverse bedrijfssectoren
60

24

16

sterk stijgend

dalend

sterk stijgend

constant sterk stijgend sterk dalend

sterk stijgend sterk dalend constant sterk dalend sterk stijgend sterk dalend sterk stijgend -

- 
Tabel 2.9 (vervolg)

Belangrijkste bedrijfssectoren per beroepsgroep, gemiddelde 1995-1996

Beroepsgroep $\%$

\section{Natuurwetenschappers}

Overige kwartaire diensten

Onderwijs

Zakelijke dienstverlening

Overheid

Andere bedrijfssectoren

\section{Conciërges}

Onderwijs

Zakelijke dienstveriening

Overige kwartaire diensten

Overheid

Andere bedrijfssectoren

\section{Hoofden technische dienst}

Metaalproducten

Andere bedrijfssectoren

\section{Werktuigbouwkundigen}

Diverse bedrijfssectoren

\section{Bouwvakkers}

Bouw

Hout- en bouwmaterialen

Metaalproducten

Andere bedrijfssectoren

\section{Aannemers en installateurs}

Bouw

Metaalproducten

Zakelijke dienstverlening

Andere bedrijfssectoren

\section{Architecten en bouwkundig projectleiders}

Zakelijke dienstveriening

Bouw

Overheid

Andere bedrijfssectoren

64

Weg- en waterbouwkundigen

Zakelijke dienstverlening

Overheid

Andere bedrijfssectoren

\author{
stijgend \\ dalend \\ stijgend \\ sterk stijgend
}

dalend

sterk stijgend

dalend

dalend

-

constant

constant

constant

dalend

-

constant

sterk dalend

sterk stijgend

-

stijgend

constant

constant

-

dalend

sterk stijgend 
Tabel 2.9 (vervolg)

Belangrijkste bedrijfssectoren per beroepsgroep, gemiddelde 1995-1996

Beroepsgroep

$\%$

trend

1994-'96

Weg- en waterbouwkundige arbeiders

Bouw

66

constant

Overheid

18

dalend

Andere bedrijfssectoren

Weg- en waterbouwkundige vakkrachten

Bouw
Overheid
Veehouderij
Zakelijke dienstverlening
Andere bedrijfssectoren

dalend

sterk dalend sterk stijgend

Weg- en waterbouwkundig ontwerpers en projectleiders

Overheid

constant

Andere bedrijfssectoren

Metaalarbeiders

Metaalproducten

stijgend

Machine-industrie

stijgend

Transportmiddelen

Basismetaal

Reparatie

Elektrotechniek

Bouw

Handel

Andere bedrijfssectoren

dalend

constant

dalend

sterk dalend

stijgend

stijgend

\title{
Bankwerkers en lassers
}

Metaalproducten

Machine-industrie

Transportmiddelen

Basismetaal

Onderwijs

Elektrotechniek

Handel

Andere bedrijfssectoren

stijgend

sterk stijgend

dalend

sterk dalend

sterk stijgend

sterk stijgend

sterk dalend

\section{Bedrijfshoofden metaalbewerking}

Diverse bedrijfssectoren

\section{Assembleurs}

\author{
Handel \\ Transportmiddelen \\ Reparatie \\ Andere bedrijfssectoren
}

27

sterk stijgend

constant

constant 
Tabel 2.9 (vervolg)

Belangrijkste bedrijfssectoren per beroepsgroep, gemiddelde 1995-1996

Beroepsgrop

1994-'96

\section{Monteurs}

$\begin{array}{lcl}\text { Reparatie } & 21 & \text { constant } \\ \text { Machine-industrie } & 11 & \text { sterk stijgend } \\ \text { Handel } & 10 & \text { dalend } \\ \text { Weg- en railvervoer } & 8 & \text { constant } \\ \text { Transportmiddelen } & 6 & \text { stijgend } \\ \text { Bouw } & 5 & \text { sterk stijgend } \\ \text { Metaalproducten } & 5 & \text { stijgend } \\ \text { Andere bedrijfssectoren } & 32 & \text { - }\end{array}$

Werktuigbouwkundig ontwerpers en hoofden technische dienst

Machine-industrie

Zakelijke dienstverlening

Energie

Andere bedrijfssectoren

stijgend

sterk stijgend

stijgend

\section{Elektronicamonteurs}

Handel

29

-

Andere bedrijfssectoren

dalend

Monteurs en controleurs elektrotechnische producten

Elektrotechniek

Bouw

Handel

Andere bedrijfssectoren

\section{Elektromonteurs}

\section{Bouw}

Elektrotechniek

Energie

Handel

Communicatie

Andere bedriffssectoren

Elektrotechnisch ontwerpers en bedrijfshoofden

Elektrotechniek

Andere bedrijfssectoren

Diverse bedrijfssectoren

\section{Elektrotechnici}

\section{Grafisch productiepersoneel}

Grafische industrie

Papier

Andere bedrijfssectoren constant sterk stijgend sterk stijgend

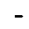

stijgend constant sterk dalend stijgend constant -

constant -

constant constant 
Tabel 2.9 (vervolg)

Belangrijkste bedrijfssectoren per beroepsgroep, gemiddelde 1995-1996

Beroepsgroep

$\%$

trend

1994-'96

\section{Grafische vakkrachten}

Grafische industrie

Zakelijke dienstverlening

constant

Andere bedrijfssectoren

\section{Mechanisch operators}

\section{Handel}

Overige voedingsproducten

Vlees- en visverwerking

Kunststofverwerking

Eindproducten chemie

Andere bedrijfssectoren

constant

stijgend

stijgend

constant

sterk dalend

Procesoperators

Overige voedingsproducten

sterk dalend

Basischemie

sterk stijgend

Eindproducten chemie

sterk stijgend

Papier

Kunststofverwerking

Energie

Handel

Andere bedrijfssectoren

sterk dalend

dalend

sterk dalend

stijgend

\section{Procestechnologen}

Diverse bedrijfssectoren

\section{Materiaalkundigen}

Zakelijke dienstverlening

dalend

Andere bedrijfssectoren

\section{Confectie-arbeiders}

Textiel

sterk dalend

Handel

Metaalproducten

Overige commerciële dienstverlening

Andere bedrijfssectoren

\section{Schoen- en kleermakers}

Textiel

Andere bedrijfssectoren sterk stijgend

\section{TRANSPORTBEROEPEN}

\section{Laders en lossers}

Handel

Weg-en railvervoer

Andere bedrijfssectoren dalend

dalend 
Tabel 2.9 (vervolg)

Belangrijkste bedrijfssectoren per beroepsgroep, gemiddelde 1995-1996

\begin{tabular}{lll}
\hline Beroepsgroep & $\%$ & trend
\end{tabular}

\section{Chauffeurs}

Weg-en railvervoer

Handel

Communicatie

Andere bedrijfssectoren

Schippers en conducteurs

Weg-en railvervoer

Scheeps- en luchtvaart

Andere bedrijfssectoren

Vliegers, scheepskapiteins en leidinggevenden transport

Scheeps- en luchtvaart

Weg-en railvervoer

Andere bedrijfssectoren

\section{Stewards}

Scheeps- en luchtvaart

Andere bedrijfssectoren

\section{MEDISCHE EN PARAMEDISCHE BEROEPEN}

\section{Verpleeghulpen en leerling-verpleegkundigen}

Gezondheidszorg

Andere bedrijfssectoren

Verplegenden en doktersassistenten

Gezondheidszorg

Andere bedrijfssectoren

Therapeuten en verpleegkundigen

Gezondheidszorg

Andere bedrijfssectoren

Gezondheidszorg

Andere bedrijfssectoren

\section{Apothekersassistenten en medisch laboranten}

\author{
Handel \\ Gezondheidszorg \\ Elektrotechniek \\ Andere bedrijfssectoren
}

constant constant dalend -

constant sterk stijgend

-

dalend constant

constant

constant

constant

constant

constant

dalend stijgend sterk stijgend 
Tabel 2.9 (vervolg)

Belangrijkste bedrijfssectoren per beroepsgroep, gemiddelde 1995-1996

Beroepsgroep $\quad \% \quad$ trend

\section{Medisch analisten}

Gezondheidszorg

Andere bedrijfssectoren

\section{Apothekers}

Diverse bedrijfssectoren

\section{Afdelingshoofden zorginstelling}

Gezondheidszorg

Andere bedrijfssectoren

\section{ECONOMISCH-ADMINISTRATIEVE BEROEPEN}

\section{Kantoorhulpen, inpakkers en colporteurs}

Metaalproducten

Handel

Zakelijke dienstverlening

Overige commerciële dienstverlening

Overige voedingsproducten

Vlees- en visverwerking

Grafische industrie

Andere bedrijfssectoren

constant

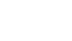

constant

Ondersteunende administratieve hulpkrachten

Zakelijke dienstverlening

constant

Andere bedrijfssectoren

sterk stijgend sterk stijgend sterk stijgend sterk dalend sterk stijgend sterk stijgend sterk dalend

\section{Bedrijfshoofden}

Zakelijke dienstverlening

Handel

Andere bedrijfssectoren

\section{Economen}

Overheid

dalend

Andere bedrijfssectoren

sterk stijgend

\section{Productieplanners}

Handel

Weg-en railvervoer

Metaalproducten

Andere bedrijfssectoren

\section{Organisatie-adviseurs}

Zakelijke dienstverlening

Overheid

Andere bedrijfssectoren 
Tabel 2.9 (vervolg)

Belangrijkste bedrijfssectoren per beroepsgroep, gemiddelde 1995-1996

\begin{tabular}{lll}
\hline Beroepsgroep & $\%$ & trend \\
& & $1994-96$
\end{tabular}

\section{Organisatiedeskundigen}

Zakelijke dienstverlening

Andere bedrijfssectoren

stijgend

Receptionisten en administratieve employés

Overheid

Handel

Zakelijke dienstveriening

Gezondheidszorg

Andere bedrijfssectoren

\section{Boekhouders en secretaresses}

Zakelijke dienstverlening

Overheid

Handel

Gezondheidszorg

Onderwijs

Andere bedrijfssectoren

\section{Assistent accountants}

\author{
Zakelijke dienstveriening \\ Overheid \\ Handel \\ Gezondheidszorg \\ Bankwezen \\ Andere bedrijfssectoren
}

13

13

12

10

52 sterk dalend

constant

stijgend

stijgend

stijgend

dalend

constant

dalend

constant

dalend

sterk dalend

constant

stijgend

constant

-

\section{Accountants}

Zakelijke dienstverlening

dalend

Overheid

Handel

Andere bedrijfssectoren

sterk stijgend

sterk stijgend

\section{Verzekeringsagenten}

Overheid

Verzekeringswezen

Zakelijke dienstverlening

Andere bedrijfssectoren

\section{Commercieel employés}

\author{
Handel \\ Bankwezen \\ Verzekeringswezen \\ Zakelijke dienstverlening \\ Weg-en railvervoer \\ Andere bedrijfssectoren
}

sterk dalend sterk stijgend sterk stijgend -

stijgend dalend stijgend constant sterk stijgend 
Tabel 2.9 (vervolg)

Belangrijkste bedrijfssectoren per beroepsgroep, gemiddelde 1995-1996

Beroepsgroep $\%$

trend

1994-'96

\section{Commercieel medewerkers}

Handel

Bankwezen

Zakelijke dienstverlening

Andere bedriifssectoren

trend
$1994-96$

Technisch-commercieel employés

Handel

Andere bedrijfssectoren

sterk stijgend

Technisch-bedrijfskundig medewerkers

Diverse bedrijfssectoren

Juridisch en fiscaal medewerkers

Overheid

Zakelijke dienstverlening

Andere bedrijfssectoren

constant

dalend

Juridisch, bestuurlijk medewerkers

Overheid

dalend

Zakelijke dienstverlening

Andere bedrijfssectoren

stijgend

Juristen

Overheid

Zakelijke dienstverlening

Andere bedrijfssectoren

constant

stijgend

Administratieve transportemployés

Weg-en railvervoer

Handel

Andere bedrijfssectoren

\section{Leidinggevenden}

Handel
Onderwijs
Overheid
Bouw
Overige kwartaire diensten
Zakelijke dienstverlening
Weg- en railvervoer
Andere bedrijfssectoren

sterk stijgend dalend stijgend sterk dalend dalend sterk stijgend sterk dalend 
Tabel 2.9 (vervolg)

Belangrijkste bedrijfssectoren per beroepsgroep, gemiddelde 1995-1996

\begin{tabular}{lll}
\hline Beroepsgroep & $\%$ & trend
\end{tabular}

1994-'96

\section{Managers}

Gezondheidszorg

21

Overheid

Onderwijs

Zakelijke dienstverlening

Andere bedrijfssectoren

\section{Medisch secretaresses}

Gezondheidszorg

Andere bedrijfssectoren

\section{INFORMATICABEROEPEN}

\section{Programmeurs}

Zakelijke dienstverlening

Overheid

Handel

Bankwezen

Communicatie

Andere bedrijfssectoren

\section{Systeemanalisten}

Zakelijke dienstverlening

Handel

Overheid

Bankwezen

Elektrotechniek

Verzekeringswezen

Andere bedrijfssectoren

\section{Informatici}

Zakelijke dienstverlening

Andere bedrijfssectoren

\section{Technisch systeemanalisten}

Zakelijke dienstverlening

Andere bedrijfssectoren

\section{SOCIAAL-CULTURELE BEROEPEN}

Activiteitenbegeleiders en medewerkers arbeidsbemiddeling sterk stijgend

dalend

constant

sterk stijgend

-

stijgend

8

dalend

stijgend

stijgend

dalend

stijgend

37

-

stijgend

dalend

sterk dalend

constant

dalend

sterk stijgend

24

sterk stijgend

sterk dalend

-
53

20

14

12 stijgend

dalend

dalend 
Tabel 2.9 (vervolg)

Belangrijkste bedrijfssectoren per beroepsgroep, gemiddelde 1995-1996

Beroepsgroep $\%$

$\% \quad$ trend

1994-'96

\section{Sociaal-cultureel werkers}

Gezondheidszorg

Overheid

Zakelijke dienstverlening

Onderwijs

Andere bedrijfssectoren

Sociale raadslieden en hoofden personeelszaken

Gezondheidszorg

Andere bedriifssectoren

Sociaal-wetenschappelijk medewerkers

Overheid

Andere bedriifssectoren

Sociaal-wetenschappelijk onderzoekers

Gezondheidszorg

Overheid

Andere bedrijfssectoren

\section{VERZORGENDE EN DIENSTVERLENENDE BEROEPEN}

\section{Vakkenvullers}

Handel

Andere bedrijfssectoren

\section{Interieurverzorgers}

Zakelijke dienstverlening

Horeca

Gezondheidszorg

Andere bedrijfssectoren

\section{Verkopers}

Handel

Andere bedrijfssectoren

Winkeliers

Handel

Andere bedrijfssectoren

\section{Hulpkrachten horeca en verzorging}

Gezondheidszorg

Horeca

Overige commerciële dienstverlening

Andere bedrijfssectoren constant

constant

stijgend

sterk dalend

sterk stijgend

sterk stijgend

sterk stijgend

stijgend

constant stijgend

constant

-

constant stijgend constant -

constant constant dalend 
Tabel 2.9 (vervolg)

Belangrijkste bedrijfssectoren per beroepsgroep, gemiddelde 1995-1996

Beroepsgroep $\%$

\section{Sociaal-cultureel werkers}

Gezondheidszorg

Overheid

Zakelijke dienstverlening

Onderwijs

Andere bedrijfssectoren

Sociale raadslieden en hoofden personeelszaken

Gezondheidszorg

Andere bedrijfssectoren

Sociaal-wetenschappelijk medewerkers

Overheid

Andere bedrijfssectoren

Sociaal-wetenschappelijk onderzoekers

Gezondheidszorg

Overheid

Andere bedrijfssectoren

\section{VERZORGENDE EN DIENSTVERLENENDE BEROEPEN}

\section{Vakkenvullers}

Handel

Andere bedrijfssectoren

\section{Interieurverzorgers}

Zakelijke dienstverlening

Horeca

Gezondheidszorg

Andere bedrijfssectoren

\section{Verkopers}

Handel

Andere bedrijfssectoren

Winkeliers

Handel

Andere bedrijfssectoren

\section{Hulpkrachten horeca en verzorging}

\author{
Gezondheidszorg \\ Horeca \\ Overige commerciële dienstveriening \\ Andere bedrijfssectoren
}

constant

constant

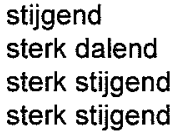

sterk stijgend

stijgend

constant stijgend

constant

constant stijgend constant -

-

constant constant dalend 
Tabel 2.9 (vervolg)

Belangrijkste bedrijfssectoren per beroepsgroep, gemiddelde 1995-1996

\begin{tabular}{lll}
\hline Beroepsgroep & $\%$ & trend
\end{tabular}

\section{Ziekenverzorgenden}

Gezondheidszorg

Andere bedrijfssectoren

\section{Verzorgend personeel}

Gezondheidszorg

Overige commerciële dienstverlening

Horeca

Andere bedrijfssectoren

Café- en snackbarhouders

Horeca

Andere bedrijfssectoren

\section{Bedrijfshoofden horeca}

\section{Horeca}

Overige kwartaire diensten

Andere bedrijfssectoren

\section{Bakkers en slagers}

Handel

Overige voedingsproducten

Andere bedrijfssectoren

\section{OPENBARE ORDE- EN VEILIGHEIDSBEROEPEN}

Aspirant politieagenten, soldaten en beveiligingshulpkrachten

Overheid

Zakelijke dienstverlening

Andere bedrijfssectoren

Politieagenten, onderofficieren en beveiligingsemployés

Overheid

Andere bedrijfssectoren

\section{Politie-inspecteurs en officieren}

Overheid

constant

\section{Brandweerlieden}

Overheid

Andere bedrijfssectoren constant

constant constant constant

-

constant

dalend

sterk stijgend

$$
\text { - }
$$

dalend

sterk stijgend

stijgend

dalend

$-$

constant

Bron: ROA 
Tabel 2.10

Uitwijkmogelijkheden naar verschillende bedrijfssectoren per beroepsgroep, gemiddelde 1995-1996

Beroepsgroep spreidingsindex typering

\section{PEDAGOGISCHE BEROEPEN}

Leraar basisonderwijs

Docenten exacte, medische en verzorgende vakken (2e graads)

Docenten exacte, medische en verzorgende vakken (1e graads)

Docenten landbouw en techniek (2e graads)

Docenten landbouw en techniek (1e graads)

Docenten economisch-administratieve vakken (2e graads.)

Docenten economisch-administratieve vakken (1e graads)

Docenten talen en expressie

Docenten letteren (1e graads)

Docenten sociale vakken ( 2 e graads)

Docenten sociale vakken (1e graads)

Docenten 2e graads zonder specialisatie

Docent 1e graads zonder specialisatie

Onderwijskundig medewerkers

Onderwijskundigen en pedagogen

Rij-instructeurs

Zweminstructeurs

Sportinstructeurs

\section{CULTURELE BEROEPEN}

Tolken, vertalers en schrijvers

Bibliotheekassistenten

Bibliothecarissen

Grafisch ontwerpers

Kunstenaars

Geestelijk verzorgers

Geestelijken

Journalisten

Taalkundigen

\section{AGRARISCHE BEROEPEN}

Agrarische hulparbeiders

Agrarische arbeiders

Agrarische vakkrachten

Milieuhygiënisten en agrarisch vertegenwoordigers

Landbouwkundigen

Landbouwmachinebestuurders en vissers

Agrarische bedrijfshoofden

laag

gemiddeld gemiddeld gemiddeld laag gemiddeld erg laag erg laag gemiddeld gemiddeld

$\begin{array}{ll}1,48 & \text { erg laag } \\ 2,46 & \text { laag } \\ 6,07 & \text { gemiddeld } \\ 5,77 & \text { gemiddeld } \\ 5,00 & \text { gemiddeld } \\ 2,21 & \text { laag } \\ 1,11 & \text { erg laag }\end{array}$

\section{TECHNISCHE EN INDUSTRIEBEROEPEN}

\author{
Productiemedewerkers \\ Laboratorium-assistenten \\ Laboranten \\ Technisch analisten \\ Conciërges \\ Werktuigbouwkundigen \\ Aannemers en installateurs \\ Architecten en bouwkundig projectleiders
}

16,17

7,62

7,71

7,67

5,51

6,65

13,24

13,24
1,96

2,38

3,95 
Tabel 2.10 (vervolg)

Uitwijkmogelijkheden naar verschillende bedrijfssectoren per beroepsgroep, gemiddelde 1995-1996

\begin{tabular}{lcl}
\hline Beroepsgroep & spreidingsindex & typering \\
\hline & & gemiddeld \\
Weg- en waterbouwkundigen & 3,11 & laag \\
Weg- en waterbouwkundige arbeiders & 2,11 & gemiddeld \\
Weg- en waterbouwkundige vakkrachten & 3,49 & gemiddeld \\
Weg-en waterbouwkundig ontwerpers en projectleiders & 2,83 & hoog \\
Metaalarbeiders & 6,98 & hoog \\
Bankwerkers en lassers & 7,34 & gemiddeld \\
Bedrijfshoofden metaalbewerking & 4,37 & hoog \\
Assembleurs & 8,89 & erg hoog \\
Monteurs & 11,37 & erg hoog \\
Werktuigbouwkundig ontwerpers en hoofden technische dienst & 14,12 & hoog \\
Elektronicamonteurs & 8,16 & hoog \\
Monteurs en controleurs elektrotechnische producten & 7,47 & gemiddeld \\
Elektromonteurs & 6,06 & erg hoog \\
Elektrotechnisch ontwerpers en bedrijfshoofden & 10,84 & hoog \\
Elektrotechnici & 9,22 & gemiddeld \\
Grafisch productiepersoneel & 3,05 & gemiddeld \\
Grafische vakkrachten & 2,94 & gemiddeld \\
Mechanisch operators & 6,11 & gemiddeld \\
Procesoperators & 4,70 & hoog \\
Procestechnologen & 7,25 & hoog \\
Materiaalkundigen & 9,18 & hoog \\
Confectie-arbeiders & 7,82 & gemiddeld \\
Schoen- en kleermakers & 5,07 & \\
& & \\
\hline
\end{tabular}

\section{TRANSPORTBEROEPEN}

Laders en lossers

Chauffeurs

Schippers en conducteurs

Vliegers, scheepskapiteins en leidinggevenden transport

\section{MEDISCHE EN PARAMEDISCHE BEROEPEN}

Verpleeghulpen en leerling-verpleegkundigen

Verplegenden en doktersassistenten

Therapeuten en verpleegkundigen

Artsen

Apothekersassistenten en medisch laboranten

erg laag

Medisch analisten

Apothekers

Afdelingshoofden zorginstelling

\section{ECONOMISCH-ADMINISTRATIEVE BEROEPEN}

Kantoorhulpen, inpakkers en colporteurs

Ondersteunende administratieve hulpkrachten

Bedrijfshoofden

Economen

Productieplanners

Organisatie-adviseurs erg laag

Organisatiedeskundigen

Receptionisten en administratieve employés

Boekhouders en secretaresses

Assistent accountants

Accountants 
Tabel 2.10 (vervolg)

Uitwijkmogelijkheden naar verschillende bedrijfssectoren per beroepsgroep, gemiddelde 1995-1996

Beroepsgroep $\quad$ spreidingsindex typering

Verzekeringsagenten

Commercieel employés

Commercieel medewerkers

Technisch-commercieel employés

Technisch-bedrijfskundig medewerkers

Juridisch en fiscaal medewerkers

Juridisch, bestuurlijk medewerkers

Juristen

Administratieve transportemployés

Leidinggevenden

Managers

Medisch secretaresses

\section{INFORMATICA BEROEPEN}

Programmeurs

Systeemanalisten

Informatici

Technisch systeemanalisten

\section{SOCIAAL-CULTURELE BEROEPEN}

Activiteitenbegeleiders en medewerkers arbeidsbemiddeling Sociaal-cultureel werkers

Sociale raadslieden en hoofden personeelszaken

Sociaal-wetenschappelijk medewerkers

Sociaal-wetenschappelijk onderzoekers

\section{VERZORGENDE EN DIENSTVERLENENDE BEROEPEN}

\author{
Vakkenvullers \\ Interieurverzorgers \\ Verkopers \\ Winkeliers \\ Hulpkrachten horeca en verzorging \\ Ziekenverzorgenden \\ Verzorgend personeel \\ Café- en snackbarhouders \\ Bedrijfshoofden horeca \\ Bakkers en slagers
}

\section{OPENBARE ORDE- EN VEILIGHEIDSBEROEPEN}

Aspirant politieagenten, soldaten en beveiligingshulpkrachten Politieagenten, onderofficieren en beveiligingsemployés

Politie-inspecteurs en officieren

Brandweerlieden

$\begin{aligned} 3,42 & \text { gemiddeld } \\ 9,79 & \text { hoog } \\ 7,14 & \text { hoog } \\ 7,63 & \text { hoog } \\ 12,98 & \text { erg hoog } \\ 1,61 & \text { laag } \\ 2,11 & \text { laag } \\ 2,72 & \text { gemiddeld } \\ 6,61 & \text { hoog } \\ 14,89 & \text { erg hoog } \\ 7,74 & \text { hoog } \\ 1,17 & \text { erg laag }\end{aligned}$

13,02

7,56

4,47

10,35

erg hoog

hoog gemiddeld hoog

$\begin{array}{ll}2,91 & \text { gemiddeld } \\ 4,09 & \text { gemiddeld } \\ 1,93 & \text { laag } \\ 1,94 & \text { laag } \\ 2,80 & \text { gemiddeld }\end{array}$

$\begin{array}{ll}1,82 & \text { laag } \\ 5,61 & \text { gemiddeld } \\ 1,63 & \text { laag } \\ 1,71 & \text { laag } \\ 2,95 & \text { gemiddeld } \\ 1,04 & \text { erg laag } \\ 2,04 & \text { laag } \\ 1,40 & \text { erg laag } \\ 1,95 & \text { laag } \\ 1,97 & \text { laag }\end{array}$

Bron: ROA/CBS

Toelichting:

De indicator voor uitwijkmogelijkheden geeft aan in welke mate arbeidskrachten met een bepaald beroep terecht kunnen komen in andere bedrijfssectoren. Deze maatstaf geeft daarmee aan in hoeverre arbeidskrachten afhankelijk zijn van de arbeidsmarktsituatie in een bepaalde bedrijfssector. De uitwijkmogelijkheden worden bepaald met behulp van de Gini-Hirschman-spreidingsindex. Deze indicator kan geïnterpreteerd worden als genormeerd aantal bedrijfssectoren waarin mensen in deze beroepsgroep werkzaam zijn. 
Tabel 2.11

Belangrijkste opleidingstypen per beroepsgroep, gemiddelde 1995-1996

\begin{tabular}{lll}
\hline Beroepsgroep & $\%$ & trend \\
& & $1992-' 96$ \\
\hline
\end{tabular}

\section{PEDAGOGISCHE BEROEPEN}

\section{Leraar basisonderwijs}

HBO lerarenopleiding basisonderwijs $\quad 86$

Andere opleidingstypen

Docenten exacte, medische en verzorgende vakken (2e graads)

$\mathrm{HBO}$ lerarenopleiding natuur en techniek HBO lerarenopleiding medisch en verzorging

Andere opleidingstypen

Docenten exacte, medische en verzorgende vakken (1e graads)

WO wiskunde en natuurwetenschappen HBO lerarenopleiding natuur en techniek

Andere opleidingstypen

Docenten landbouw en techniek (2e graads)

HBO lerarenopleiding natuur en techniek Andere opleidingstypen

Docenten landbouw en techniek (1e graads)

\section{Docenten economisch-administratieve vakken (2e graads)}

HBO lerarenopleiding economie en maatschappij

Andere opleidingstypen

Docenten economisch-administratieve vakken (1e graads)

Diverse opleidingstypen

\section{Docenten talen en expressie}

HBO lerarenopleiding talen

HBO lerarenopleiding expressie

$\mathrm{HBO}$ uitvoerende en beeldende kunsten

HBO lerarenopleiding basisonderwijs

Andere opleidingstypen

\section{Docenten letteren (1e graads)}

WO letteren

HBO lerarenopleiding talen

HBO lerarenopleiding expressie

Andere opleidingstypen

\section{Docenten sociale vakken (2e graads)}

HBO lerarenopleiding lichamelijke opvoeding

Andere opleidingstypen constant

-

stijgend

dalend

-

dalend

stijgend

constant

constant

constant

stijgend

stijgend

dalend

-

dalend

constant

stijgend 
Tabe/ 2.11 (vervolg)

Belangrijkste opleidingstypen per beroepsgroep, gemiddelde 1995-1996

\begin{tabular}{lll}
\hline Beroepsgroep & $\%$ & trend \\
$1992-' 96$
\end{tabular}

Docenten sociale vakken (1e graads)

WO sociale wetenschappen

Andere opleidingstypen

dalend

-

Docenten 2e graads zonder specialisatie

HBO lerarenopleiding economie en maatschappij

$\mathrm{HBO}$ lerarenopleiding natuur en techniek

constant

Andere opleidingstypen

\section{sterk stijgend}

Docent 1e graads zonder specialisatie

Diverse opleidingstypen

Onderwijskundig medewerkers

Diverse opleidingstypen

Onderwijskundigen en pedagogen

WO sociale wetenschappen

Andere opleidingstypen

dalend

Rij-instructeurs

MBO/LLW vervoer

Andere opleidingstypen

dalend

\section{Zweminstructeurs}

\section{Sportinstructeurs}

Diverse opleidingstypen

\section{CULTURELE BEROEPEN}

Tolken, vertalers en schrijvers

Wo letteren

Andere opleidingstypen

\section{Bibliotheekassistenten}

MBO sociaal-cultureel

Andere opleidingstypen

stijgend

\section{Bibliothecarissen}


Tabel 2.11 (vervolg)

Belangrijkste opleidingstypen per beroepsgroep, gemiddelde 1995-1996

\begin{tabular}{lll}
\hline Beroepsgroep & $\%$ & trend \\
& & $1992-96$
\end{tabular}

\section{Grafisch ontwerpers}

MBO/LLW grafische techniek

Andere opleidingstypen

\section{Kunstenaars}

HBO uitvoerende en beeldende kunsten

Andere opleidingstypen

46

\section{Geestelijk verzorgers}

\section{Geestelijken}

WO theologie

Andere opleidingstypen

\section{Journalisten}

HBO communicatie en journalistiek

HAVONWO

Andere opleidingstypen

\section{Taalkundigen}

WO letteren

Andere opleidingstypen

\section{AGRARISCHE BEROEPEN}

\section{Agrarische hulparbeiders}

Diverse opleidingstypen

\section{Agrarische arbeiders}

Basisonderwijs

MBO/LLW landbouw en veeteelt

VBO landbouw en natuurlijke omgeving

$\mathrm{MBO} / \mathrm{LLW}$ milieu en groene ruimte

MAVO

VBO verzorging

Andere opleidingstypen

Agrarische vakkrachten

MBO/LLW landbouw en veeteelt

Andere opleidingstypen stijgend

96 constant

constant

$$
-
$$

stijgend constant

constant - 
Tabel 2.11 (vervolg)

Belangrijkste opleidingstypen per beroepsgroep, gemiddelde 1995-1996

\begin{tabular}{lll}
\hline Beroepsgroep & $\%$ & trend \\
& $1992-' 96$ \\
\hline
\end{tabular}

\section{Landbouwkundigen}

\section{Landbouwmachinebestuurders en vissers}

Diverse opleidingstypen

\section{Agrarische bedrijfshoofden}

MBO/LLW landbouw en veeteelt

VBO landbouw en natuurlijke omgeving

Basisonderwijs

MBO/LLW handel

Andere opleidingstypen

$\begin{aligned} 37 & \text { constant } \\ 21 & \text { dalend } \\ 7 & \text { dalend } \\ 5 & \text { constant } \\ 30 & -\end{aligned}$

\section{TECHNISCHE EN INDUSTRIEBEROEPEN}

Laboratorium-assistenten

\section{Productiemedewerkers}

Basisonderwijs

MAVO

VBO verzorging

Andere opleidingstypen

Laboratorium-assistenten

Diverse opleidingstypen

\section{Laboranten}

MBO/LLW laboratorium

Andere opleidingstypen

\section{Technisch analisten}

HBO laboratorium

Andere opleidingstypen

\section{Natuurwetenschappers}

WO wiskunde en natuurwetenschappen

Andere opleidingstypen

\section{Conciërges}

\section{Basisonderwijs}

MAVO

Andere opleidingstypen dalend constant constant<smiles>[CH]=C</smiles>

constant

-

constant

dalend

sterk stijgend 
Tabel 2.11 (vervolg)

Belangrijkste opleidingstypen per beroepsgroep, gemiddelde 1995-1996

Beroepsgroep $\quad \%$ trend

1992-'96

Hoofden technische dienst

MBO/LLW elektrotechniek

Andere opleidingstypen

sterk stijgend

Werktuigbouwkundigen

Diverse opleidingstypen

\section{Bouwvakkers}

VBO bouwtechniek

Basisonderwijs

MBO/LLW bouw

MAVO

Andere opleidingstypen

\section{Aannemers en installateurs}

MBO/LLW bouw

MBO/LLW installatietechniek

VBO bouwtechniek

MBO/LLW werktuigbouw en mechanische techniek

Basisonderwijs

Andere opleidingstypen

Architecten en bouwkundig projectleiders

HBO bouwkunde

MBO/LLW bouw

Andere opleidingstypen

Weg- en waterbouwkundigen

WO bouwkunde

Andere opleidingstypen

Weg- en waterbouwkundige arbeiders

Basisonderwijs

MBO/LLW grond-, weg- en waterbouw

VBO bouwtechniek

Andere opleidingstypen

Weg- en waterbouwkundige vakkrachten

MBO/LLW grond-, weg- en waterbouw

Basisonderwijs

Andere opleidingstypen

Weg- en waterbouwkundig ontwerpers en projectleiders

HBO civiele techniek dalend

\author{
constant \\ dalend \\ stijgend \\ constant
}

constant constant

dalend

constant

dalend

-

constant

dalend

-

constant

stijgend

dalend

-

dalend

constant

- 
Tabel 2.11 (vervolg)

Belangrijkste opleidingstypen per beroepsgroep, gemiddelde 1995-1996

Beroepsgroep $\%$ trend

\section{Metaalarbeiders}

VBO mechanische techniek

Basisonderwijs

$\mathrm{MBO} / \mathrm{LLW}$ werktuigbouw en mechanische techniek

MAVO

Andere opleidingstypen

Bankwerkers en lassers

$\mathrm{MBO} / \mathrm{LLW}$ werktuigbouw en mechanische techniek

VBO mechanische techniek

MBO/LLW fijnmechanische techniek

Andere opleidingstypen

\section{Bedrijfshoofden metaalbewerking}

\section{Assembleurs}

Basisonderwijs

MBO/LLW motorvoertuigentechniek

Andere opleidingstypen

\section{Monteurs}

MBO/LLW motorvoertuigentechniek

MBO/LLW werktuigbouw en mechanische techniek

constant constant dalend

constant dalend stijgend stijgend

$7 \quad$ stijgend
MBO/LLW elektrotechniek

VBO mechanische techniek

Basisonderwijs

Andere opleidingstypen

$\begin{aligned} 18 & \text { stijgend } \\ 18 & \text { constant } \\ 9 & \text { constant } \\ 7 & \text { dalend } \\ 7 & \text { dalend }\end{aligned}$

Werktuigbouwkundig ontwerpers en hoofden technische dienst

$\mathrm{HBO}$ werktuigbouwkunde

MBO/LLW werktuigbouw en mechanische techniek

HBO vervoer en logistiek

Andere opleidingstypen

\section{Elektronicamonteurs}

MBO/LLW elektrotechniek

constant

Andere opleidingstypen

stijgend

sterk dalend

constant

\section{Monteurs en controleurs elektrotechnische producten}

MBO/LLW elektrotechniek

VBO elektrotechniek 
Tabel 2.11 (vervolg)

Belangrijkste opleidingstypen per beroepsgroep, gemiddelde 1995-1996

Beroepsgroep $\quad \% \quad$ trend

1992-' 96

\section{Elektrotechnisch ontwerpers en bedrijfshoofden}

HBO elektrotechniek

Andere opleidingstypen

41

59

Diverse opleidingstypen

Grafisch productiepersoneel

MBO/LLW grafische techniek

Basisonderwijs

Andere opleidingstypen dalend

$-$

Grafische vakkrachten

MBO/LLW grafische techniek

Basisonderwijs

Andere opleidingstypen

Mechanisch operators

Basisonderwijs

MAVO

MBO/LLW levensmiddelentechniek/vleesverwerking

Andere opleidingstypen

\section{Procesoperators}

MBO/LLW procestechniek

Basisonderwijs

MBO/LLW brood en banket

Andere opleidingstypen

Procestechnologen

Diverse opleidingstypen

Materiaalkundigen

WO wiskunde en natuurwetenschappen

Andere opleidingstypen

dalend

\section{Confectie-arbeiders}

Basisonderwijs

MBO/LLW handel

MAVO

VBO verzorging

VBO administratie, handel en textiel

Andere opleidingstypen

- constant constant

stijgend

dalend

-

dalend

constant stijgend

stijgend

dalend

stijgend constant

constant sterk stijgend sterk dalend sterk dalend 
Tabel 2.11 (vervolg)

Belangrijkste opleidingstypen per beroepsgroep, gemiddelde 1995-1996

Beroepsgroep $\%$ trend

Schoen- en kleermakers

MBO/LLW handel

Andere opleidingstypen

\section{TRANSPORTBEROEPEN}

\section{Laders en lossers}

Basisonderwijs

MAVO

Andere opleidingstypen

\section{Chauffeurs}

\author{
Basisonderwijs \\ VBO vervoer \\ MAVO \\ VBO mechanische techniek \\ Andere opleidingstypen
}

\section{Schippers en conducteurs}

MBO/LLW vervoer

Andere opleidingstypen

Vliegers, scheepskapiteins en leidinggevenden transport

HBO vervoer en logistiek

Andere opleidingstypen

\section{Stewards}

HAVO/VWO

Andere opleidingstypen

\section{MEDISCHE EN PARAMEDISCHE BEROEPEN}

Verpleeghulpen en leerling-verpleegkundigen

\author{
MAVO \\ MBO/LLW verzorging \\ VBO verzorging \\ HAVO/MWO \\ Basisonderwijs \\ Andere opleidingstypen
}

\section{Verplegenden en doktersassistenten}

MBO/LLW verpleging

MBO dokters-, tandarts- en dierenartsassistent

$\mathrm{HBO}$ verpleegkunde

Andere opleidingstypen sterk stijgend

dalend

stijgend

constant constant constant dalend$$
\text { - }
$$

stijgend

constant

$$
\text { - }
$$

stijgend$$
\text { - }
$$

stijgend sterk dalend stijgend constant sterk stijgend

$$
\text { - }
$$

constant

stijgend

dalend 


\begin{tabular}{lll}
\hline Beroepsgroep & $\%$ & trend \\
$1992-96$
\end{tabular}

\section{Therapeuten en verpleegkundigen}

HBO (fysio)therapie

$\mathrm{HBO}$ verpleegkunde

MBO/LLW verpleging

Andere opleidingstypen

\section{Artsen}

WO (dier)geneeskunde

WO tandheelkunde

WO sociale wetenschappen

Andere opleidingstypen

Apothekersassistenten en medisch laboranten

MBO/LLW apothekersassistent

MBO/LLW gezondheidstechniek

MBO/LLW laboratorium

Andere opleidingstypen

\section{Medisch analisten}

HBO laboratorium

$\mathrm{HBO}$ radiologie

Andere opleidingstypen

\section{Apothekers}

WO farmacie

Andere opleidingstypen

Afdelingshoofden zorginstelling

HBO maatschappelijk werk en hulpverlening

Andere opleidingstypen

\section{ECONOMISCH-ADMINISTRATIEVE BEROEPEN}

\section{Kantoorhulpen, inpakkers en colporteurs}

Basisonderwijs

MAVO

VBO verzorging

Andere opleidingstypen

Ondersteunende administratieve hulpkrachten

Diverse opleidingstypen

\section{Bedrijfshoofden}

Diverse opleidingstypen constant

constant

constant

$-$

constant

constant

sterk stijgend

-

\section{constant \\ constant \\ sterk stijgend}

constant

constant

-

stijgend

constant

-

dalend

sterk stijgend

sterk dalend 
Tabel 2.11 (vervolg)

Belangrijkste opleidingstypen per beroepsgroep, gemiddelde 1995-1996

Beroepsgroep $\%$

trend

1992-'96

\section{Economen}

WO econom(etr)ie

Andere opleidingstypen

Productieplanners
MAVO

HAVONWO

MBO/LLW administratie

$\mathrm{MBO} / L L W$ handel

Basisonderwijs

$\mathrm{MBO} / L L W$ vervoer

MBO/LLW elektrotechniek

Andere opleidingstypen

\section{Organisatie-adviseurs}

HBO bedrijfskunde

Andere opleidingstypen

\section{Organisatiedeskundigen}

WO bedrijfskunde

WO sociale wetenschappen

WO econom(etr)ie

Andere opleidingstypen

Receptionisten en administratieve employés

MAVO

Basisonderwijs

VBO administratie, handel en textiel

MBO/LLW administratie

HAVONWO

MBO/LLW secretariaat

VBO verzorging

Andere opleidingstypen

stijgend

dalend

constant

dalend

dalend

sterk stijgend

sterk stijgend

sterk stijgend

-

-

stijgend

dalend

stijgend

-

constant constant dalend constant constant stijgend daiend

-

constant

constant constant constant constant

HAVONWO

MBO/LLW secretariaat

MAVO

MBO/LLW handel

Andere opleidingstypen

$-$

\section{Assistent accountants}

$\mathrm{HBO}$ accountancy en bedrijfseconomie

Andere opleidingstypen

stijgend dalend sterk dalend sterk dalend 
Tabel 2.11 (vervolg)

Belangrijkste opleidingstypen per beroepsgroep, gemiddelde 1995-1996

\begin{tabular}{lll}
\hline Beroepsgroep & $\%$ & trend \\
& & $1992-$ ' $96^{2}$ \\
\hline
\end{tabular}

\title{
Accountants
}

HBO accountancy en bedrijfseconomie

WO accountancy en belastingen

WO econom(etr)ie

MBO/LLW administratie

Andere opleidingstypen

\section{Verzekeringsagenten}

$\begin{array}{lll}\text { MBO/LLW administratie } & 21 & \text { constant } \\ \text { HAVO/NWO } & 18 & \text { constant } \\ \text { MAVO } & 12 & \text { dalend } \\ \text { Andere opleidingstypen } & 49 & -\end{array}$

\section{Commercieel employés}

MBO/LLW administratie

stijgend

HAVOMWO

MAVO

MBO/LLW handel

MBO verzekeringswezen

Andere opleidingstypen

dalend

constant

\section{Commercieel medewerkers}

\author{
MBO/LLW handel \\ HBO commerciële economie \\ HAVO/MWO \\ MBO/LLW administratie \\ MAVO \\ Andere opleidingstypen
}

Technisch-commercieel employés

MBO/LLW handel

MBO/LLW werktuigbouw en mechanische techniek

Andere opleidingstypen

\section{Technisch-bedrijfskundig medewerkers}

HBO werktuigbouwkunde

Andere opleidingstypen

\section{Juridisch en fiscaal medewerkers}

MBO/LLW geld, bank en belastingen

MAVO

MBO/LLW administratie

HAVONWO

Andere opleidingstypen

-

sterk stijgend

Juridisch, bestuurlijk medewerkers

Diverse opleidingstypen

- stijgend

dalend

constant

stijgend

dalend

constant

constant

-

sterk dalend

stijgend

constant

dalend 
Tabel 2.11 (vervolg)

Belangrijkste opleidingstypen per beroepsgroep, gemiddelde 1995-1996

\begin{tabular}{lll}
\hline Beroepsgroep & $\%$ & trend \\
& $1992-96$ \\
\hline
\end{tabular}

\section{Juristen}

WO rechten en bestuurskunde

WO accountancy en belastingen

Andere opleidingstypen

59

8

32

Administratieve transportemployés

MBO/LLW vervoer

MAVO

HAVONWO

Andere opleidingstypen

Leidinggevenden

MBO/LLW handel

HBO bedrijfskunde

HBO lerarenopleiding basisonderwijs

Andere opleidingstypen

16

12

8

63

\section{Managers}

WO sociale wetenschappen

WO rechten en bestuurskunde

Andere opleidingstypen

Medisch secretaresses

MBO/LLW secretariaat

Andere opleidingstypen

\section{INFORMATICA BEROEPEN}

\section{Programmeurs}

MBO/LLW automatisering

HAVOMWO

MAVO

MBO/LLW administratie

Andere opleidingstypen

\section{Systeemanalisten}

$\mathrm{HBO}$ informatica

HBO elektrotechniek

HAVOIMWO

Andere opleidingstypen

\section{Informatici}

Diverse opleidingstypen constant

constant stijgend

-

stijgend

constant

constant

constant

sterk stijgend

stijgend

-

constant constant

-

-

dalend

constant

stijgend

constant

stijgend

-

constant

constant

dalend 
Tabel 2.11 (vervolg)

Belangrijkste opleidingstypen per beroepsgroep, gemiddelde 1995-1996

\begin{tabular}{lll}
\hline Beroepsgroep & $\%$ & trend \\
$1992-96$
\end{tabular}

Technisch systeemanalisten

HBO elektrotechniek

HBO informatica

Andere opleidingstypen
31

28

40 constant

sterk stijgend

\section{SOCIAAL-CULTURELE BEROEPEN}

Activiteitenbegeleiders en medewerkers arbeidsbemiddeling

MBO sociaal-cultureel

MBO/LLW beweging en therapie

HAVOMWO

HBO maatschappelijk werk en hulpverlening

$\mathrm{MBO} / \mathrm{LLW}$ verzorging

Andere opleidingstypen

Sociaal-cultureel werkers

HBO maatschappelijk werk en hulpverlening

$\mathrm{HBO}$ personeelswerk

WO sociale wetenschappen

Andere opleidingstypen

\section{Sociale raadslieden en hoofden personeelszaken}

WO sociaal-cultureel overig

WO sociale wetenschappen

Andere opleidingstypen

Sociaal-wetenschappelijk medewerkers

Diverse opleidingstypen

Sociaal-wetenschappelijk onderzoekers

WO sociale wetenschappen

Andere opleidingstypen

70

\section{VERZORGENDE EN DIENSTVERLENENDE BEROEPEN}

\section{Vakkenvullers}

MAVO

HAVONWO

Andere opleidingstypen

\section{Interieurverzorgers}

Basisonderwijs

VBO verzorging

MAVO

MBO/LLW verzorging

Andere opleidingstypen constant sterk stijgend stijgend

dalend

dalend

constant

sterk dalend

sterk stijgend

constant

dalend

-

constant

- dalend

sterk stijgend 
Tabel 2.11 (vervolg)

Belangrijkste opleidingstypen per beroepsgroep, gemiddelde 1995-1996

Beroepsgroep $\%$ trend

1992-'96

\title{
Verkopers
}

MBO/LLW handel

stijgend

MAVO

dalend

VBO verzorging

constant

Basisonderwijs

dalend

VBO administratie, handel en textiel

HAVOMWO

Andere opleidingstypen

dalend

stijgend

\section{Winkeliers}

\author{
MBO/LLW handel \\ MAVO \\ Basisonderwijs \\ HAVONWO \\ Andere opleidingstypen
}

Hulpkrachten horeca en verzorging

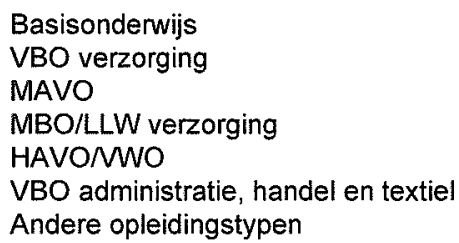

$\begin{aligned} 20 & \text { dalend } \\ 19 & \text { dalend } \\ 14 & \text { constant } \\ 9 & \text { stijgend } \\ 6 & \text { stijgend } \\ 6 & \text { dalend } \\ 27 & -\end{aligned}$

\section{Ziekenverzorgenden}

MBO/LLW verzorging

$\mathrm{MBO} / \mathrm{LLW}$ verpleging

Andere opleidingstypen

$\begin{aligned} 38 & \text { constant } \\ 9 & \text { constant } \\ 6 & \text { sterk dalend } \\ 6 & \text { stijgend } \\ 42 & -\end{aligned}$

Verzorgend personeel

MBO/LLW verzorging

MBO/LLW uiterlijke verzorging

$\mathrm{MBO} / \mathrm{LLW}$ horeca

$\mathrm{MBO} / \mathrm{LLW}$ verpleging

MBO sociaal-cultureel

Andere opleidingstypen

Café- en snackbarhouders

MBO/LLWW horeca

Andere opleidingstypen

\section{Bedrijfshoofden horeca}

MBO/LLW horeca

Basisonderwijs

MAVO

HAVOMWO

Andere opleidingstypen constant stijgend constant

- 
Tabel 2.11 (vervolg)

Belangrijkste opleidingstypen per beroepsgroep, gemiddelde 1995-1996

\begin{tabular}{lll}
\hline Beroepsgroep & $\%$ & trend
\end{tabular}

\section{Bakkers en slagers}

MBO/LLW levensmiddelentechniek/vleesverwerking

MBO/LLW brood en banket

Andere opleidingstypen

\section{OPENBARE ORDE- EN VEILIGHEIDSBEROEPEN}

\section{Aspirant politieagenten, soldaten en beveiligingshulpkrachten}

MBO openbare orde en veiligheid

VBO beveiliging

MAVO

HAVOMWO

Andere opleidingstypen

Politieagenten, onderofficieren en beveiligingsemployés

MBO openbare orde en veiligheid

Andere opleidingstypen

MBO openbare orde en veiligheid Andere opleidingstypen

\section{Brandweerlieden}

MBO openbare orde en veiligheid Andere opleidingstypen 
Tabel 2.12

Substitutiemogelijkheden tussen mensen met uiteenlopende opleidingsachtergronden per beroepsgroep, gemiddelde 1995-1996

Beroepsgroep $\quad$ spreidingsindex typering

\section{PEDAGOGISCHE BEROEPEN}

Leraar basisonderwijs

Docenten exacte, medische en verzorgende vakken (2e graads)

Docenten exacte, medische en verzorgende vakken (1e graads)

Docenten landbouw en techniek (2e graads)

Docenten landbouw en techniek (1e graads)

Docenten economisch-administratieve vakken (2e graads)

Docenten economisch-administratieve vakken (1e graads)

Docenten talen en expressie

Docenten letteren (1e graads)

Docenten sociale vakken (2e graads)

Docenten sociale vakken (1e graads)

Docenten 2 e graads zonder specialisatie

Docent 1 e graads zonder specialisatie

Onderwijskundig medewerkers

Onderwijskundigen en pedagogen

Rij-instructeurs

Zweminstructeurs

Sportinstructeurs

\section{CULTURELE BEROEPEN}

Tolken, vertalers en schrijvers

Bibliotheekassistenten

Bibliothecarissen

Grafisch ontwerpers

Kunstenaars

Geestelijk verzorgers

Geestelijken

Journalisten

Taalkundigen

\section{AGRARISCHE BEROEPEN}

Agrarische hulparbeiders

Agrarische arbeiders

Agrarische vakkrachten

Milieuhygiënisten en agrarisch vertegenwoordigers

Landbouwkundigen

Landbouwmachinebestuurders en vissers

Agrarische bedrijfshoofden

\section{TECHNISCHE EN INDUSTRIEBEROEPEN}

Productiemedewerkers

Laboratorium-assistenten

Laboranten

Technisch analisten

Natuurwetenschappers

Conciërges

Hoofden technische dienst

Werktuigbouwkundigen

Bouwvakkers

Aannemers en installateurs
1,36

2,93

6,37

3,60

5,16

3,03

2,73
2,18

7,62

7,14

6,61

2,75

6,38

9,88

6,02

2,04

6,15

4,46

1,08

9,50

5,55

gemiddeld

hoog

erg laag

gemiddeld

laag

erg laag

erg laag

hoog

gemiddeld

gemiddeld gemiddeld gemiddeld hoog

laag

gemiddeld laag

gemiddeld

gemiddeld

gemiddeld

erg laag

2,44

2,95

14,24

12,33

12,28

5,55

6,31 laag

hoog

hoog

hoog

gemiddeld

gemiddeld 
Tabel 2.12 (vervolg)

Substitutiemogelijkheden tussen mensen met uiteenlopende opleidingsachtergronden per beroepsgroep, gemiddelde 1995-1996

\begin{tabular}{lcc}
\hline Beroepsgroep & spreidingsindex & typering \\
\hline & & \\
Architecten en bouwkundig projectleiders & 9,46 & gemiddeld \\
Weg- en waterbouwkundigen & 4,72 & laag \\
Weg- en waterbouwkundige arbeiders & 6,33 & gemiddeld \\
Weg- en waterbouwkundige vakkrachten & 9,85 & hoog \\
Weg- en waterbouwkundig ontwerpers en projectleiders & 3,89 & laag \\
Metaalarbeiders & 6,93 & gemiddeld \\
Bankwerkers en lassers & 5,81 & gemiddeld \\
Bedrijfshoofden metaalbewerking & 12,45 & hoog \\
Assembleurs & 12,29 & hoog \\
Monteurs & 11,04 & hoog \\
Werktuigbouwkundig ontwerpers en hoofden technische dienst & 10,24 & hoog \\
Elektronicamonteurs & 2,75 & laag \\
Monteurs en controleurs elektrotechnische producten & 7,66 & gemiddeld \\
Elektromonteurs & 2,89 & laag \\
Elektrotechnisch ontwerpers en bedrijfshoofden & 4,53 & laag \\
Elektrotechnici & 6,35 & gemiddeld \\
Grafisch productiepersoneel & 7,42 & gemiddeld \\
Grafische vakkrachten & 5,73 & gemiddeld \\
Mechanisch operators & 10,33 & hoog \\
Procesoperators & 12,73 & hoog \\
Procestechnologen & 17,40 & erg hoog \\
Materiaalkundigen & 8,96 & gemiddeld \\
Confectie-arbeiders & 6,87 & gemiddeld \\
Schoen- en kleermakers & 4,33 & laag
\end{tabular}

\section{TRANSPORTBEROEPEN}

Laders en lossers

Chauffeurs

11,51

11,89

Schippers en conducteurs

Vliegers, scheepskapiteins en leidinggevenden transport

Stewards

hoog

\section{MEDISCHE EN PARAMEDISCHE BEROEPEN}

Verpleeghulpen en leerling-verpleegkundigen

Verplegenden en doktersassistenten

Therapeuten en verpleegkundigen

4,62

Artsen

Apothekersassistenten en medisch laboranten

Medisch analisten

Apothekers

Afdelingshoofden zorginstelling

gemiddeld laag laag erg laag gemiddeld laag laag gemiddeld

\section{ECONOMISCH-ADMINISTRATIEVE BEROEPEN}

Kantoorhulpen, inpakkers en colporteurs

Ondersteunende administratieve hulpkrachten

Bedrijfshoofden

Economen

Productieplanners

Organisatie-adviseurs

Organisatiedeskundigen

Receptionisten en administratieve employés

Boekhouders en secretaresses gemiddeld erg hoog erg hoog gemiddeld erg hoog erg hoog gemiddeld gemiddeld gemiddeld 
Tabel 2.12 (vervolg)

Substitutiemogelijkheden tussen mensen met uiteenlopende opleidingsachtergronden per beroepsgroep, gemiddelde 1995-1996

Beroepsgroep $\quad$ spreidingsindex typering

Assistent accountants

10,61

5,78

Accountants

Verzekeringsagenten

Commercieel employés

Commercieel medewerkers

Technisch-commercieel employés

Technisch-bedrijfskundig medewerkers

Juridisch en fiscaal medewerkers

Juridisch, bestuurlijk medewerkers

Juristen

Administratieve transportemployés

Managers

Medisch secretaresses

\section{INFORMATICA BEROEPEN}

Programmeurs

8,51

Systeemanalisten

Informatici

Technisch systeemanalisten

10,69

16,36

5,28

SOCIAAL-CULTURELE BEROEPEN

Activiteitenbegeleiders en medewerkers arbeidsbemiddeling

13,56

5,93

Sociaal-cultureel werkers

2,94

14,15

Sociaal-wetenschappelijk medewerkers

Sociaal-wetenschappelijk onderzoekers
Leidinggevenden

hoog

gemiddeld

hoog

erg hoog

erg hoog

hoog

erg hoog

gemiddeld

erg hoog

laag

hoog

erg hoog

erg hoog

gemiddeld

gemiddeld

hoog

erg hoog

laag

hoog

gemiddeld

laag

hoog

erg laag

\section{VERZORGENDE EN DIENSTVERLENENDE BEROEPEN}

\author{
Vakkenvullers \\ Interieurverzorgers \\ Bedrijfshoofden horeca \\ Bakkers en slagers
}

8,22

6,71

10,44

6,18

8,66

1,55

7,43

10,14

8,84

4,29 middeld gemiddeld hoog gemiddeld gemiddeld erg laag gemiddeld hoog gemiddeld laag

\section{OPENBARE ORDE- EN VEILIGHEIDSBEROEPEN}

Aspirant politieagenten, soldaten en beveiligingshulpkrachten

$\begin{aligned} 14,16 & \text { hoog } \\ 1,84 & \text { erg laag } \\ 6,44 & \text { gemiddeld } \\ 2,88 & \text { laag }\end{aligned}$

Politieagenten, onderofficieren en beveiligingsemployés

Politie-inspecteurs en officieren

Brandweerlieden

Bron: ROA 
Toelichting:

De indicator voor substitutiemogelijkheden geeft de mate aan waarin werkgevers voor een bepaald beroep arbeidskrachten kunnen aantrekken met een uiteenlopende opleidingsachtergrond, zodat ze niet afhankelijk zijn van het arbeidsaanbod van een bepaald opleidingstype. De substitutiemogelijkheden worden bepaald met behulp van de Gini-Hirschman-spreidingsindex. Deze indicator kan geïnterpreteerd worden als een genormeerd aantal opleidingstypen waaruit werkenden in deze beroepsgroep afkomstig zijn. 
Tabel 2.13

Conjunctuurgevoeligheid per beroepsgroep

\section{PEDAGOGISCHE BEROEPEN}

Leraar basisonderwijs

Docenten exacte, medische en verzorgende vakken (2e graads)

0,79

0,74

0,21

0,76

Docenten landbouw en techniek (2e graads)

Docenten landbouw en techniek (1e graads)

Docenten economisch-administratieve vakken (2e graads)

Docenten economisch-administratieve vakken (1e graads)

Docenten talen en expressie

Docenten letteren (1e graads)

Docenten sociale vakken (2e graads)

Docenten sociale vakken (1e graads)

Docenten 2e graads zonder specialisatie

Docent 1e graads zonder specialisatie

Onderwijskundig medewerkers

Onderwijskundigen en pedagogen

Rij-instructeurs

Zweminstructeurs

Sportinstructeurs

\section{CULTURELE BEROEPEN}

Tolken, vertalers en schrijvers

0,18

Bibliotheekassistenten

Bibliothecarissen

Grafisch ontwerpers

Kunstenaars

Geestelijk verzorgers

Geestelijken

Journalisten

Taalkundigen

\section{AGRARISCHE BEROEPEN}

Agrarische hulparbeiders

Agrarische arbeiders

Agrarische vakkrachten

Milieuhygiënisten en agrarisch vertegenwoordigers

Landbouwkundigen

Landbouwmachinebestuurders en vissers

Agrarische bedrijfshoofden gemiddeld

gemiddeld

erg laag

gemiddeld

erg laag

gemiddeld

erg laag

gemiddeld

erg laag

gemiddeld

erg laag

gemiddeld

erg laag

laag

erg laag

erg hoog

erg laag

erg laag

\section{TECHNISCHE EN INDUSTRIEBEROEPEN}

Productiemedewerkers

erg laag gemiddeld erg laag hoog erg laag erg laag erg laag gemiddeld laag

Laboratorium-assistenten

Laboranten

Natuurwetenschappers

Conciërges

laag
laag
hoog
gemiddeld
laag
laag
erg laag

laag erg laag laag erg hoog erg laag gemiddeld gemiddeld erg hoog erg hoog erg hoog erg hoog 
Weg-en waterbouwkundigen

Weg-en waterbouwkundige arbeiders

Weg-en waterbouwkundige vakkrachten

Weg- en waterbouwkundig ontwerpers en projectleiders

Metaalarbeiders

Bankwerkers en lassers

Bedrijfshoofden metaalbewerking

Assembleurs

Monteurs

Werktuigbouwkundig ontwerpers en hoofden technische dienst

Elektronicamonteurs

Monteurs en controleurs elektrotechnische producten

Elektromonteurs

Elektrotechnisch ontwerpers en bedrijfshoofden

Elektrotechnici

Grafisch productiepersoneel

Grafische vakkrachten

Mechanisch operators

Procesoperators

Procestechnologen

Materiaalkundigen

Confectie-arbeiders

Schoen-en kleermakers

\section{TRANSPORTBEROEPEN}

Laders en lossers

Chauffeurs

Schippers en conducteurs

Vliegers, scheepskapiteins en leidinggevenden transport

Stewards

\section{MEDISCHE EN PARAMEDISCHE BEROEPEN}

Verpleeghulpen en leerling-verpleegkundigen

Verplegenden en doktersassistenten

Therapeuten en verpleegkundigen

Artsen

Apothekersassistenten en medisch laboranten

Medisch analisten

Apothekers

Afdelingshoofden zorginstelling

0,62

1,56

1,90

0,41

1,66 gemiddeld

erg hoog

hoog

erg hoog

erg hoog

hoog

gemiddeld

hoog

gemiddeld

gemiddeld

gemiddeld

erg hoog

hoog

gemiddeld

erg hoog

gemiddeld

erg hoog

gemiddeld

gemiddeld

hoog

gemiddeld

hoog

erg hoog

\section{ECONOMISCH-ADMINISTRATIEVE BEROEPEN}

Kantoorhulpen, inpakkers en colporteurs

Ondersteunende administratieve hulpkrachten

Bedrijfshoofden

Economen

Productieplanners

Organisatie-adviseurs

Organisatiedeskundigen

Receptionisten en administratieve employés

Boekhouders en secretaresses

Assistent accountants

Accountants
0,60

0,57

0,38

0,12

0,43

0,38

0,78

1,05 laag

erg hoog

erg hoog

laag

erg hoog

laag
laag
erg laag
erg laag
laag
erg laag
gemiddeld
hoog

laag gemiddeld erg hoog gemiddeld hoog erg hoog laag laag gemiddeld hoog laag 
Verzekeringsagenten

Commercieel employés

Commercieel medewerkers

Technisch-commercieel employés

Technisch-bedrijfskundig medewerkers

Juridisch en fiscaal medewerkers

Juridisch, bestuurlijk medewerkers

Juristen

Administratieve transportemployés

Leidinggevenden

Managers

Medisch secretaresses

\section{INFORMATICA BEROEPEN}

Programmeurs

Systeemanalisten

Informatici

Technisch systeemanalisten

$\begin{array}{ll}0,42 & \text { laag } \\ 0,84 & \text { gemiddeld } \\ 1,24 & \text { hoog } \\ 1,10 & \text { hoog } \\ 1,39 & \text { erg hoog } \\ 0,22 & \text { erg laag } \\ 0,46 & \text { laag } \\ 0,52 & \text { laag } \\ 1,19 & \text { hoog } \\ 1,20 & \text { hoog } \\ 0,74 & \text { gemiddeld } \\ 0,58 & \text { laag }\end{array}$

0,82

1,18

0,51

0,54

gemiddeld

hoog

laag

laag

\section{SOCIAAL-CULTURELE BEROEPEN}

Activiteitenbegeleiders en medewerkers arbeidsbemiddeling

Sociaal-cultureel werkers

Sociale raadslieden en hoofden personeelszaken

0,19

Sociaal-wetenschappelijk medewerkers

0,50

Sociaal-wetenschappelijk onderzoekers

0,31

gemiddeld

gemiddeld

erg laag

laag

erg laag

\section{VERZORGENDE EN DIENSTVERLENENDE BEROEPEN}

Vakkenvullers

Interieurverzorgers

Verkopers

0,48

Winkeliers

0,65

Hulpkrachten horeca en verzorging

0,84

Ziekenverzorgenden

Verzorgend personeel

0,56

0,86

1,36

Café- en snackbarhouders

1,20

Bedrijfshoofden horeca

0,15

gemiddeld

erg laag

laag

gemiddeld

gemiddeld

laag

gemiddeld

erg hoog

Bakkers en slagers

hoog

erg laag

\section{OPENBARE ORDE- EN VEILIGHEIDSBEROEPEN}

Aspirant politieagenten, soldaten en beveiligingshulpkrachten

$\begin{array}{ll}0,64 & \text { gemiddeld } \\ 0,23 & \text { erg laag } \\ 0,47 & \text { laag } \\ 0,26 & \text { erg laag }\end{array}$

Politie-inspecteurs en officieren

0,26

erg laag

\section{Bron: ROA}

\section{Toelichting:}

De conjunctuurgevoeligheid van de werkgelegenheid heeft betrekking op de mate waarin de werkgelegenheid gevoelig is voor veranderingen van de economische situatie. Deze indicator geeft daarmee de mate van werkzekerheid aan in de beroepsgroep. 
Tabel 2.14

Verwachte uitbreidingsvraag per beroepsgroep, 1997-2002

\begin{tabular}{|c|c|c|c|}
\hline Beroepsgroep & aantal & $\begin{array}{c}\text { totaal } \\
\%\end{array}$ & $\begin{array}{l}\text { gemiddeld typering } \\
\text { jaarlijks \% }\end{array}$ \\
\hline
\end{tabular}

\section{PEDAGOGISCHE BEROEPEN}

Leraar basisonderwijs

Docenten exacte, medische en verzorgende vakken

(2e graads)

Docenten exacte, medische en verzorgende vakken

(1e graads)

Docenten landbouw en techniek (2e graads)

Docenten landbouw en techniek (1e graads)

Docenten economisch-administratieve vakken (2e graads)

Docenten economisch-administratieve vakken (1e graads)

Docenten talen en expressie

Docenten letteren (1e graads)

Docenten sociale vakken (2e graads)

Docenten sociale vakken (1e graads)

Docenten $2 e$ graads zonder specialisatie

Docent te graads zonder specialisatie

Onderwijskundig medewerkers

Onderwijskundigen en pedagogen

Rij-instructeurs

Zweminstructeurs

Sportinstructeurs

\section{CULTURELE BEROEPEN}

Tolken, vertalers en schrijvers

Bibliotheekassistenten

Bibliothecarissen

Grafisch ontwerpers

Kunstenaars

Geestelijk verzorgers

Geestelijken

Journalisten

Taalkundigen

\section{AGRARISCHE BEROEPEN}

Agrarische hulparbeiders

Agrarische arbeiders

Agrarische vakkrachten

Milieuhygiënisten en agrarisch vertegenwoordigers

Landbouwkundigen

Landbouwmachinebestuurders en vissers

Agrarische bedrijfshoofden

\section{TECHNISCHE EN INDUSTRIEBEROEPEN}

Productiemedewerkers

Laboratorium-assistenten

Laboranten

Technisch analisten

Natuurwetenschappers

Conciërges

Hoofden technische dienst

Werktuigbouwkundigen

Bouwvakkers

$\begin{array}{rrrl}2.600 & 2 & 0,4 & \text { laag } \\ -1.500 & -8 & -1,7 & \text { erg laag } \\ & & & \\ 2.300 & 13 & 2,5 & \text { hoog } \\ 0 & 0 & 0,0 & \text { laag } \\ - & - & - & - \\ -400 & -4 & -0,9 & \text { erg laag } \\ 300 & 5 & 0,9 & \text { gemiddeld } \\ -1.800 & -5 & -1,0 & \text { erg laag } \\ 5.300 & 20 & 3,7 & \text { hoog } \\ -700 & -6 & -1,2 & \text { erg laag } \\ -700 & -12 & -2,4 & \text { erg laag } \\ 800 & 6 & 1,2 & \text { gemiddeld } \\ - & - & - & - \\ 2.800 & 31 & 5,5 & \text { erg hoog } \\ 3.000 & 14 & 2,7 & \text { hoog } \\ 300 & 4 & 0,7 & \text { gemiddeld } \\ 300 & 7 & 1,4 & \text { gemiddeld } \\ 400 & 5 & 1,0 & \text { gemiddeld }\end{array}$

1.100

2,2 gemiddeld

$-500$

600

2.700

3.800

$-0,6$

erg laag

1,0 gemiddeld

4,8 erg hoog

1,8 gemiddeld

$-$

$-0,2$

1,8

laag

1.600

700

gemiddeld

gemiddeld
600

$-2.100$

$-800$

5.200

1.100

$-200$

$-4.500$
2,0

$-0,4$

$-1,7$

5,9

3,7

$-0,3$

$-0,7$

gemiddeld

laag

erg laag

erg hoog

hoog

laag

erg laag

$\begin{array}{rrll}8.000 & 7 & 1,4 & \text { gemiddeld } \\ - & - & - & - \\ 1.000 & 7 & 1,3 & \text { gemiddeld } \\ 1.400 & 12 & 2,3 & \text { hoog } \\ 1.700 & 11 & 2,1 & \text { gemiddeld } \\ 2.100 & 8 & 1,5 & \text { gemiddeld } \\ 0 & 0 & 0,0 & \text { laag } \\ 300 & 3 & 0,5 & \text { laag } \\ 7.000 & 4 & 0,8 & \text { gemiddeld }\end{array}$


Aannemers en installateurs

Architecten en bouwkundig projectleiders

Weg-en waterbouwkundigen

Weg-en waterbouwkundige arbeiders

Weg-en waterbouwkundige vakkrachten

Weg-en waterbouwkundig ontwerpers en projectleiders Metaalarbeiders

Bankwerkers en lassers

Bedrijfshoofden metaalbewerking

Assembleurs

Monteurs

Werktuigbouwkundig ontwerpers en hoofden technische dienst

Elektronicamonteurs

Monteurs en controleurs elektrotechnische producten

Elektromonteurs

Elektrotechnisch ontwerpers en bedrijfshoofden

Elektrotechnici

Grafisch productiepersoneel

Grafische vakkrachten

Mechanisch operators

Procesoperators

Procestechnologen

Materiaalkundigen

Confectie-arbeiders

Schoen- en kleermakers

\section{TRANSPORTBEROEPEN}

Laders en lossers

Chauffeurs

Schippers en conducteurs

Vliegers, scheepskapiteins en leidinggevenden transport

Stewards

\section{MEDISCHE EN PARAMEDISCHE BEROEPEN}

Verpleeghulpen en leerling-verpleegkundigen

Verplegenden en doktersassistenten

Therapeuten en verpleegkundigen

Artsen

Apothekersassistenten en medisch laboranten

Medisch analisten

Apothekers

Afdelingshoofden zorginstelling

10.300

gemiddeld gemiddeld erg laag hoog erg hoog

$\begin{aligned}-0,1 & \text { laag } \\ 0,6 & \text { laag } \\ 0,0 & \text { laag } \\ 2,1 & \text { gemiddeld } \\ 2,4 & \text { hoog } \\ 1,8 & \text { gemiddeld } \\ -0,5 & \text { erg laag } \\ 0,2 & \text { laag }\end{aligned}$

\section{ECONOMISCH-ADMINISTRATIEVE BEROEPEN}

Kantoorhulpen, inpakkers en colporteurs

Ondersteunende administratieve hulpkrachten

Bedrijfshoofden

Economen

Productieplanners

Organisatie-adviseurs

Organisatiedeskundigen

Receptionisten en administratieve employés gemiddeld gemiddeld hoog

laag gemiddeld laag laag gemiddeld erg hoog gemiddeld gemiddeld

laag gemiddeld laag gemiddeld laag laag laag gemiddeld laag gemiddeld laag erg hoog gemiddeld gemiddeld

$\begin{array}{cl}2,9 & \text { hoog } \\ 2,5 & \text { hoog } \\ 0,6 & \text { laag } \\ 0,9 & \text { gemiddeld } \\ 8,1 & \text { erg hoog } \\ 7,7 & \text { erg hoog } \\ 6,1 & \text { erg hoog } \\ -0,8 & \text { erg laag }\end{array}$


Tabel 2.14 (vervolg)

Verwachte uitbreidingsvraag per beroepsgroep, 1997-2002

Beroepsgroep

aantal

totaal

gemiddeld typering

jaarlijks \%

Boekhouders en secretaresses

Assistent accountants

Accountants

Verzekeringsagenten

Commercieel employés

Commercieel medewerkers

Technisch-commercieel employés

Technisch-bedrijfskundig medewerkers

Juridisch en fiscaal medewerkers

Juridisch, bestuurlijk medewerkers

Juristen

Administratieve transportemployés

Leidinggevenden

Managers

Medisch secretaresses

\section{INFORMATICA BEROEPEN}

Programmeurs

8.800

Systeemanalisten

19.000

Informatici

Technisch systeemanalisten
95.000

12.200

10.100

1.100

10.900

29.700

1.400

600

1.100

600

5.000

$-900$

6.600

7.400

3.600

23
12
35
4
4
15
7
5
3
4
10
-3
15
10
21

\section{2}

2,4

6,1

0,7

0,8

2,9

1,3

0,9

0,6

0,7

1,8

$-0,6$

2,8

1,8

3,9

erg hoog

hoog

erg hoog

gemiddeld

gemiddeld

hoog

gemiddeld

gemiddeld

laag

gemiddeld

gemiddeld

erg laag

hoog

gemiddeld

hoog

3,0 hoog

4,0 hoog

3,6 hoog

$2,0 \quad$ gemiddeld

\section{SOCIAAL-CULTURELE BEROEPEN}

Activiteitenbegeleiders en medewerkers arbeidsbemiddeling 9.800

Sociaal-cultureel werkers

5.400

Sociale raadslieden en hoofden personeelszaken

Sociaal-wetenschappelijk medewerkers

Sociaal-wetenschappelijk onderzoekers
2.100

2.700

5.600

$\begin{array}{ll}3,3 & \text { hoog } \\ 1,4 & \text { gemiddeld } \\ 3,8 & \text { hoog } \\ 6,4 & \text { erg hoog } \\ 4,7 & \text { erg hoog }\end{array}$

VERZORGENDE EN DIENSTVERLENENDE BEROEPEN

Vakkenvullers

Interieurverzorgers

Verkopers

Winkeliers

Hulpkrachten horeca en verzorging

Ziekenverzorgenden

Verzorgend personeel

Café- en snackbarhouders

Bedrijfshoofden horeca

Bakkers en slagers
3.000

16.800

19.700

8.400

4.900

18.200

31.900

1.400

3.700

500

\section{2,5 hoog}

2,1 gemiddeld

1,5 gemiddeld

1,2 gemiddeld

0,7 laag

5,4 erg hoog

3,0 hoog

2,2 hoog

1,8 gemiddeld

0,7 gemiddeld

\section{OPENBARE ORDE- EN VEILIGHEIDSBEROEPEN}

Aspirant politieagenten, soldaten en beveiligingshulpkrachten 3.900

Politieagenten, onderofficieren en beveiligingsemployés $\quad-2.900$

Politie-inspecteurs en officieren

Brandweerlieden
$-2.900$

100

$\begin{array}{rrl}9 & 1,8 & \text { gemiddeld } \\ -6 & -1,3 & \text { erg laag } \\ 0 & 0,0 & \text { laag } \\ 1 & 0,3 & \text { laag }\end{array}$

\section{Bron: ROA}

Toelichting:

Uitbreidingsvraag is de vraag naar nieuwe arbeidskrachten die ontstaat door groei van de werkgelegenheid. Als er sprake is van een werkgelegenheidsdaling, is de uitbreidingsvraag negatief. 
Tabel 2.15

Verwachte vervangingsvraag per beroepsgroep, 1997-2002

Beroepsgroep

aantal

totaa

gemiddeld typering

jaarlijks \%

\section{PEDAGOGISCHE BEROEPEN}

Leraar basisonderwijs

Docenten exacte, medische en verzorgende vakken

(2e graads)

Docenten exacte, medische en verzorgende vakken

(1e graads)

Docenten landbouw en techniek (2e graads)

Docenten landbouw en techniek (1e graads)

Docenten economisch-administratieve vakken (2e graads)

Docenten economisch-administratieve vakken

(1e graads)

Docenten talen en expressie

Docenten letteren (1e graads)

Docenten sociale vakken (2e graads)

Docenten sociale vakken (1e graads)

Docenten 2e graads zonder specialisatie

Docenten 1e graads zonder specialisatie

Onderwijskundig medewerkers

Onderwijskundigen en pedagogen

Rij-instructeurs

Zweminstructeurs

Sportinstructeurs

\section{CULTURELE BEROEPEN}

Tolken, vertalers en schrijvers

Bibliotheekassistenten

Bibliothecarissen

Grafisch ontwerpers

Kunstenaars

Geestelijk verzorgers

Geestelijken

Journalisten

Taalkundigen

\section{AGRARISCHE BEROEPEN}

Agrarische hulparbeiders

1.000

Agrarische arbeiders

Agrarische vakkrachten

19.800

1.100

2.600

800

1.700

Landbouwkundigen

Landbouwmachinebestuurders en vissers

Agrarische bedrijfshoofden
1.700

\section{0}

22

4.700

6.200

2.400

1.200

10.200

5.100

3.000

1.600

2.500

2.300

3.000

2.000

600

1.200

3.200

2.800

1.100

7.400

1.400

\section{3,7 gemiddeld}

$4,1 \quad$ hoog

4,8 hoog

6,2 erg hoog

5,2 erg hoog

3,2 gemiddeld

5,2 erg hoog

3,6 gemiddeld

4,7 hoog

4,8 erg hoog

3,6 gemiddeld

4,6 hoog

2,7 laag

4,3 hoog

2,7 laag

3,1 gemiddeld

$\begin{array}{ll}3,4 & \text { gemiddeld } \\ 3,4 & \text { gemiddeld } \\ 4,2 & \text { hoog } \\ 2,0 & \text { erg laag } \\ 3,4 & \text { gemiddeld } \\ - & - \\ 4,2 & \text { hoog } \\ 2,7 & \text { laag } \\ 2,8 & \text { laag }\end{array}$

3,1 gemiddeld

3,4 gemiddeld

2,2 erg laag

3,1 gemiddeld

2,8 laag

3,0 gemiddeld

3,9 hoog

\section{TECHNISCHE EN INDUSTRIEBEROEPEN}

Productiemedewerkers

15.100

Laboratorium-assistenten

Laboranten

Technisch analisten

Natuurwetenschappers

Conciërges

Hoofden technische dienst

Werktuigbouwkundigen

$\begin{array}{ll}2,5 & \text { laag } \\ - & - \\ 3,4 & \text { gemiddeld } \\ 3,4 & \text { gemiddeld } \\ 3,7 & \text { gemiddeld } \\ 6,0 & \text { erg hoog } \\ 3,7 & \text { gemiddeld } \\ 2,4 & \text { laag }\end{array}$


Tabel 2.15 (vervolg)

Verwachte vervangingsvraag per beroepsgroep, 1997-2002

Beroepsgroep

aantal

totaal

gemiddeld typering

$\%$ jaarlijks \%

Bouwvakkers

33.100

Aannemers en installateurs

Architecten en bouwkundig projectleiders

Weg- en waterbouwkundigen

Weg- en waterbouwkundige arbeiders

Weg-en waterbouwkundige vakkrachten

Weg- en waterbouwkundig ontwerpers en projectleiders

Metaalarbeiders

Bankwerkers en lassers

Bedrijfshoofden metaalbewerking

Assembleurs

Monteurs

Werktuigbouwkundig ontwerpers en hoofden technische

dienst

Elektronicamonteurs

Monteurs en controleurs elektrotechnische producten

Elektromonteurs

Elektrotechnisch ontwerpers en bedrijfshoofden

Elektrotechnici

Grafisch productiepersoneel

Grafische vakkrachten

Mechanisch operators

Procesoperators

Procestechnologen

Materiaalkundigen

Confectie-arbeiders

Schoen- en kleermakers

\section{TRANSPORTBEROEPEN}

Laders en lossers

Chauffeurs

Schippers en conducteurs

Vliegers, scheepskapiteins en leidinggevenden transport

Stewards

\section{MEDISCHE EN PARAMEDISCHE BEROEPEN}

Verpleeghulpen en leerling-verpleegkundigen

8.200

Verplegenden en doktersassistenten

Therapeuten en verpleegkundigen

Artsen

Apothekersassistenten en medisch laboranten

Medisch analisten

Apothekers

Afdelingshoofden zorginstelling
11.000

36.500

3.500

2.500

1.200
18.800

20.100

12.500

6.800

2.900

1.100

2.700

\section{3,5}

3,3

4,4

3,6

3,3

3,5

3,3

3,6

3,1

4,6

3,2

2,8

4,3

3,0

3,0

2,9

4,9

2,5

3,0

3,0

3,3

3,0

4,6

4,0

4,4

4,6 gemiddeld

gemiddeld

hoog

gemiddeld

gemiddeld

gemiddeld

gemiddeld

gemiddeld

gemiddeld

hoog

gemiddeld

laag

hoog

gemiddeld

gemiddeld

gemiddeld

erg hoog

laag

gemiddeld

gemiddeld

gemiddeld

gemiddeld

hoog

hoog

hoog

hoog

2,1 erg laag

3,0 gemiddeld

4,2 hoog

2,9 laag

$2,1 \quad$ erg laag

\section{ECONOMISCH-ADMINISTRATIEVE BEROEPEN}

Kantoorhulpen, inpakkers en colporteurs

Ondersteunende administratieve hulpkrachten

Bedrijfshoofden

Economen

Productieplanners

Organisatie-adviseurs

Organisatiedeskundigen

\section{6,2}

3,3

4,0

4,2

3,6

3,5

3,8

4,9

erg hoog

gemiddeld

hoog

hoog

gemiddeld

gemiddeld

hoog

erg hoog

$\begin{array}{ll}2,7 & \text { laag } \\ 2,9 & \text { laag } \\ 3,3 & \text { gemiddeld } \\ 2,3 & \text { erg laag } \\ 2,5 & \text { laag } \\ 2,4 & \text { laag } \\ 2,5 & \text { laag }\end{array}$


Receptionisten en administratieve employés

Boekhouders en secretaresses

Assistent accountants

Accountants

Verzekeringsagenten

Commercieel employés

Commercieel medewerkers

Technisch-commercieel employés

Technisch-bedrijfskundig medewerkers

Juridisch en fiscaal medewerkers

Juridisch, bestuurlijk medewerkers

Juristen

Administratieve transportemployés

Leidinggevenden

Managers

Medisch secretaresses

\subsection{0}

54.500

15.300

4.000

6.200

34.900

26.100

2.500

1.800

6.800

4.900

6.800

6.100

9.500

20.300

3.300

\section{4,8}

2,5

2,9

2,6

4,1

2,4

2,5

2,4

2,6

3,6

5,1

2,5

4,1

3,9

4,8

3,6

hoog
laag
gemiddeld
laag
hoog
laag
laag
laag
laag
gemiddeld
erg hoog
laag
hoog
hoog
hoog
gemiddeld

\section{INFORMATICA BEROEPEN}

Programmeurs

Systeemanalisten

4.800

11.000

1.600

Informatici

Technisch systeemanalisten

1.800
1,7

2,4

2,0

3,2 erg laag

laag

erg laag

gemiddeld

\section{SOCIAAL-CULTURELE BEROEPEN}

Activiteitenbegeleiders en medewerkers arbeidsbemiddeling 6.000

Sociaal-cultureel werkers

Sociale raadslieden en hoofden personeelszaken

Sociaal-wetenschappelijk medewerkers

1.400

Sociaal-wetenschappelijk onderzoekers

\section{VERZORGENDE EN DIENSTVERLENENDE BEROEPEN}

Vakkenvullers

7.300

Interieurverzorgers

Verkopers

27.700

45.600

Winkeliers

22.200

Hulpkrachten horeca en verzorging

Ziekenverzorgenden

Verzorgend personeel

Café- en snackbarhouders

Bedrijfshoofden horeca

Bakkers en slagers
31.700

10.600

24.100

4.500

7.700

2.700

\section{OPENBARE ORDE- EN VEILIGHEIDSBEROEPEN}

Aspirant politieagenten, soldaten en beveiligingshulpkrachten7 800

Politieagenten, onderofficieren en beveiligingsemployés 8.500

Bron: ROA 
Toelichting:

Vervangingsvraag is vraag naar nieuwe arbeidskrachten die ontstaat doordat de arbeidsplaatsen van werkenden die met pensioen gaan, arbeidsongeschikt worden of zich (tijdelijk) terugtrekken van de arbeidsmarkt opnieuw moeten worden opgevuld. De vervangingsvraag per beroepsgroep kan bovendien ontstaan door de beroepsmobiliteit. Vertrek van werkenden dat niet leidt tot vraag naar nieuwkomers uit dezelfde beroepsgroep wordt niet meegerekend als vervangingsvraag. 


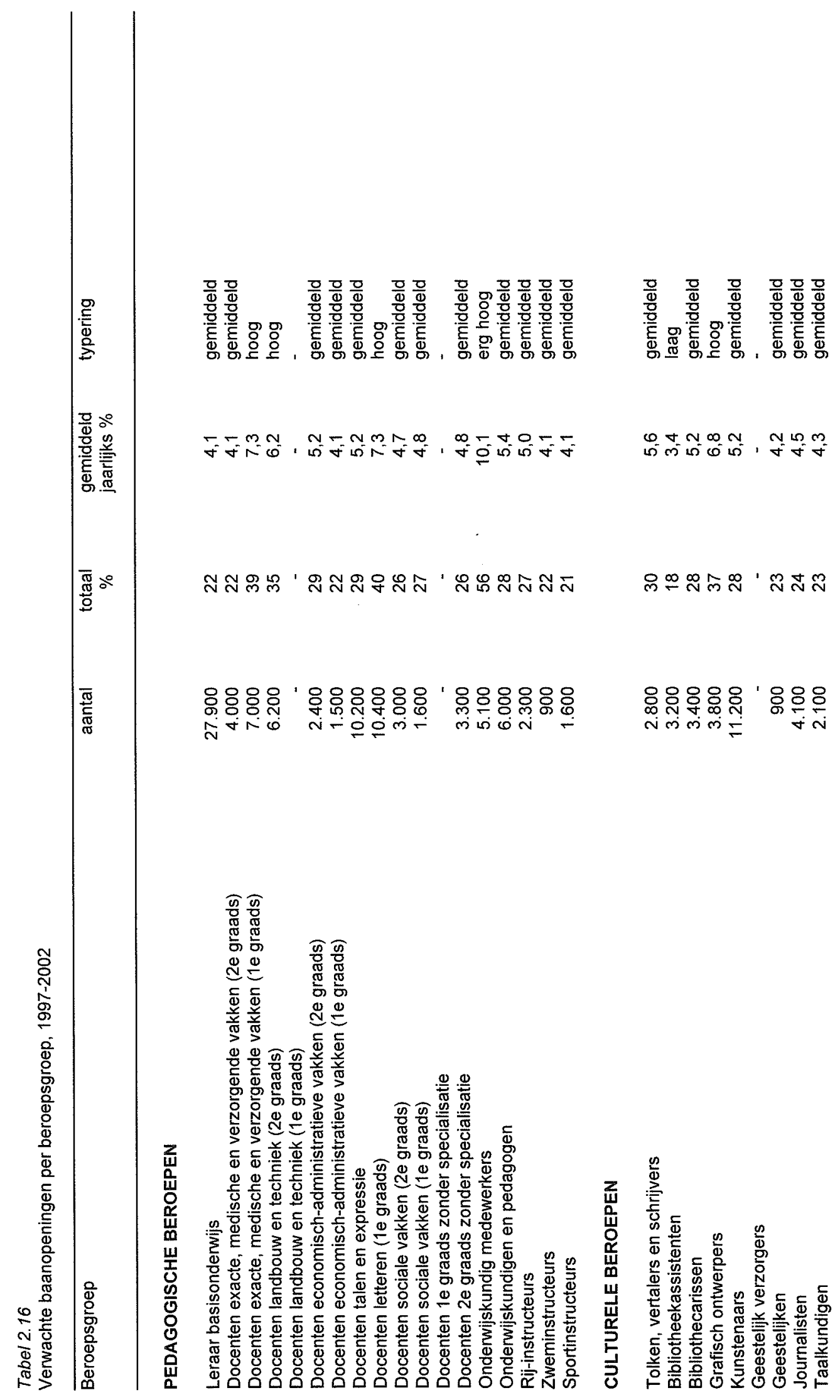




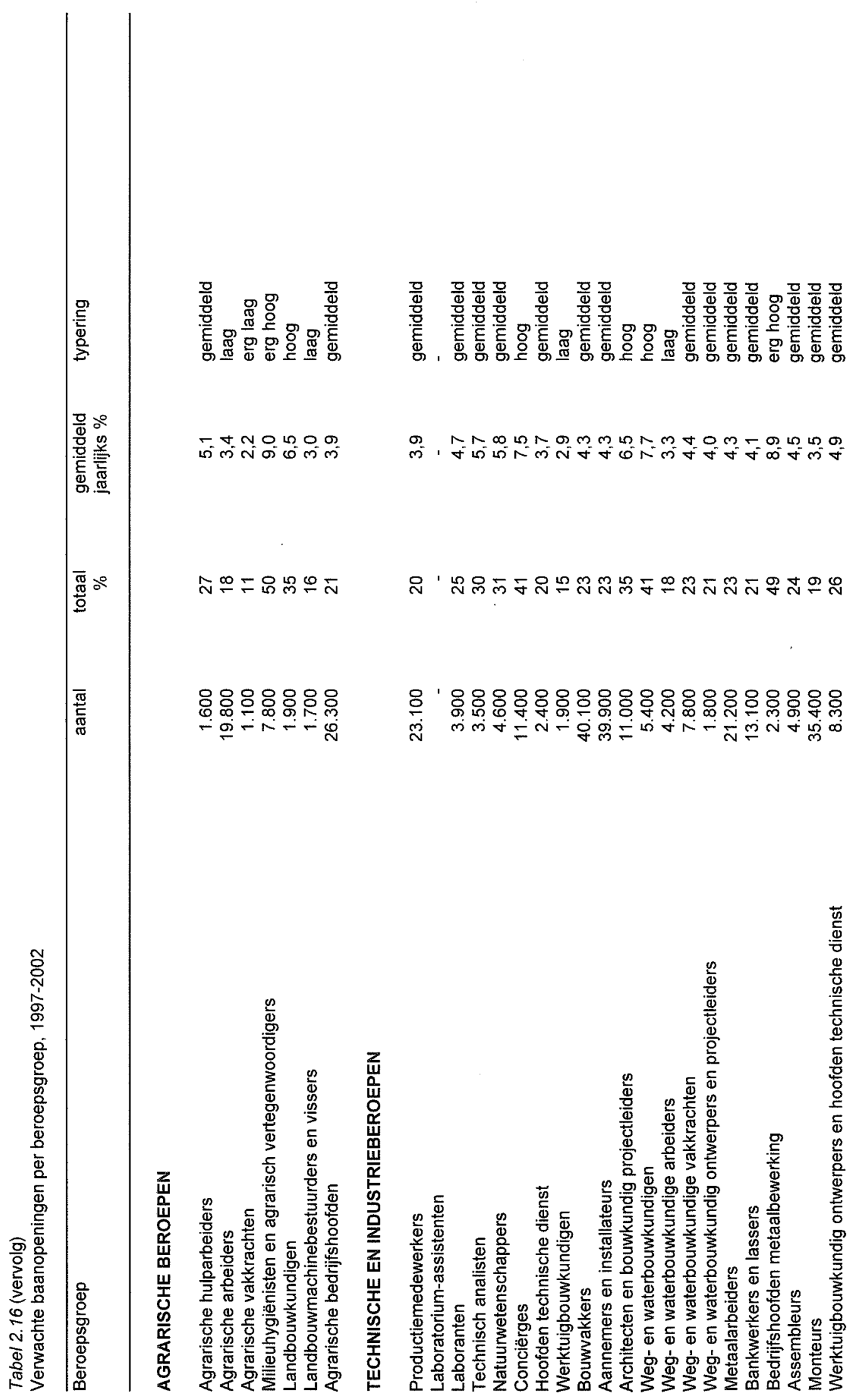




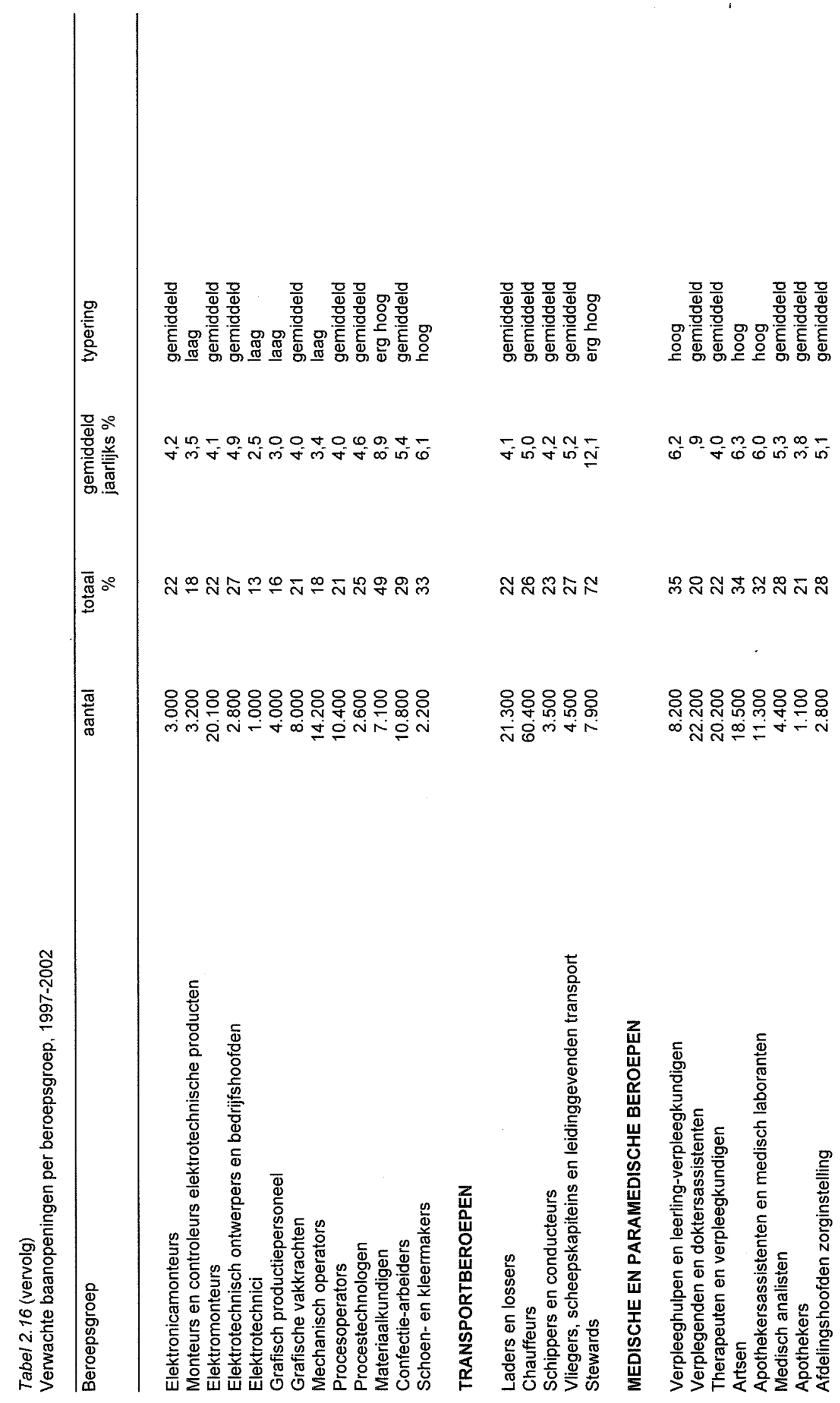




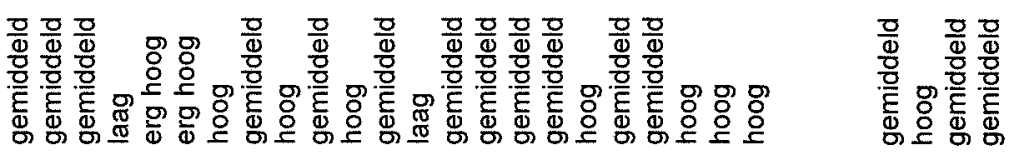

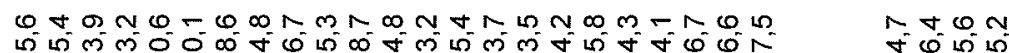

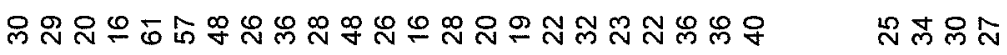

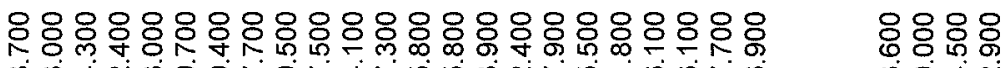

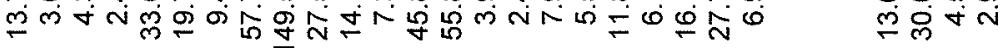

$$
\text { - }
$$




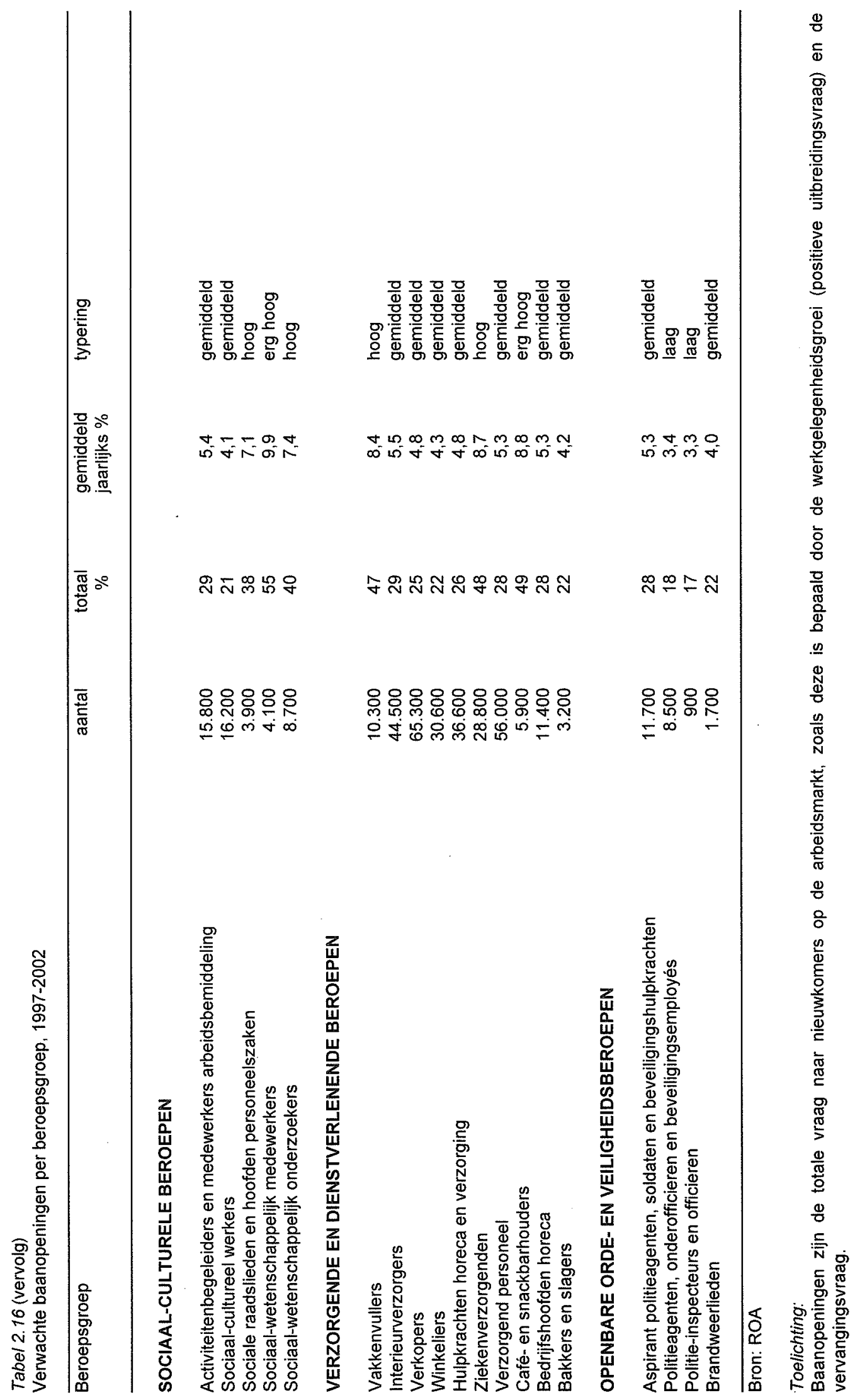


3 INFORMATIE OVER OPLEIDINGEN 
Tabel 3.1

Aantal werkenden per opleidingstype, gemiddelde 1995-1996

Opleidingstype

aantal werkenden trend

arbeidsvolume

1992-'96

\section{BASISONDERWIJS}

Basisonderwijs

483.500 dalend

435.500

MBO, VBO
MAVO
MAVO
VBO Landbouw en natuurlijke omgeving
VBO landbouw en natuurlijke omgeving
VBO Techniek
VBO bouwtechniek
VBO installatietechniek
VBO mechanische techniek
VBO fijnmechanische techniek
VBO motorvoertuigentechniek
VBO elektrotechniek
VBO grafische techniek
VBO brood en banket
VBO horeca en levensmiddelentechniek
VBO vervoer

constant

350.000

75.500 dalend

85.000

75.500 malend

131.500

constant

130.500

10.500

constant

117.000

dalend

10.500

5.000

sterk dalend

117.000

42.000

60.000

constant

5.000

constant

42.500

6.000

12.000

sterk dalend

59.000

29.000

37.500

dalend

5.500

12.500

27.000

VBO Economie

VBO administratie, handel en textiel

125.500

dalend

104.000

VBO Verzorging

VBO verzorging

184.000

constant

126.500

VBO Openbare orde en veiligheid

VBO beveiliging

12.000

sterk stijgend

11.500

HAVOIVWO, MBO/LLW

HAVONWO
HAVONWO

$314.000 \quad$ constant

272.500

MBO/LLW Landbouw en natuurlijke omgeving

$\mathrm{MBO} / \mathrm{LLW}$ landbouw en veeteelt

$\mathrm{MBO} / \mathrm{LLW}$ milieu en groene ruimte

108.000

23.000

constant

132.500

stijgend

24.000

MBO/LLW Techniek

MBO/LLW laboratorium $\quad 18.000$

MBO/LLW bouw

136.000

stijgend

16.000

MBO/LLW grond-, weg- en waterbouw

25.000

$\mathrm{MBO} / \mathrm{LLW}$ installatietechniek

24.500

MBO/LLW werktuigbouw en mechanische techniek 141.000

constant

139.000

stijgend

25.500

constant

25.500

constant

142.500

13.500

constant

13.000

MBO/LLW motorvoertuigentechniek

72.000

MBO/LLW vliegtuigtechniek

6.000

constant

75.500

constant

6.000

7.500

MBO/LLW operationele techniek

153.500

7.500

MBO/LLW elektrotechniek

39.500

MBO/LLW grafische techniek

24.000

constant

152.500

constant

39.500

stijgend

22.000 
Tabel 3.1 (vervolg)

Aantal werkenden per opleidingstype, gemiddelde 1995-1996

Opleidingstype

aantal werkenden trend

arbeidsvolume

1992-'96

MBO/LLW brood en banket

MBO/LLW levensmiddelentechniek/

vleesverwerking

MBO/LLW vervoer

MBO Dienstverlening en gezondheidszorg

MBO dokters-, tandarts- en dierenartsassistent

MBO/LLW apothekersassistent

MBO/LLW verpleging

MBO/LLW gezondheidstechniek

MBO sociaal-cultureel

MBO/LLW verzorging

MBO/LLW uiterlijke verzorging

MBO/LLW horeca

MBO/LLW beweging en therapie

\section{MBO Economie}

MBO/LLW administratie

MBO/LLW handel

MBO/LLW secretariaat

MBO/LLW toerisme en recreatie

MBO/LLW bedrijfskunde

MBO/LLW automatisering

MBO/LLW geld, bank en belastingen

$M B O$ verzekeringswezen

MBO Openbare orde en veiligheid

MBO openbare orde en veiligheid

\section{HBO}

HBO Onderwijs en tolk en vertaler

$\mathrm{HBO}$ lerarenopleiding basisonderwijs

$\mathrm{HBO}$ lerarenopleiding talen

$\mathrm{HBO}$ lerarenopleiding natuur en techniek

HBO lerarenopleiding economie en maatschappij

HBO lerarenopleiding lichamelijke opvoeding

$\mathrm{HBO}$ lerarenopleiding medisch en verzorging

$\mathrm{HBO}$ lerarenopleiding expressie

$\mathrm{HBO}$ tolk en vertaler

157.000

30.500

35.000

35.000

14.500

13.000

29.500

10.000

\section{HBO Landbouw}

$H B O$ landbouw en veeteelt

HBO milieukunde en levensmiddelentechnologie

\author{
HBO Techniek \\ HBO laboratorium . \\ HBO bouwkunde \\ HBO civiele techniek \\ HBO werktuigbouwkunde \\ HBO elektrotechniek \\ HBO informatica \\ $\mathrm{HBO}$ chemische technologie \\ $\mathrm{HBO}$ vervoer en logistiek
}

$\begin{array}{ll}\text { constant } & 16.000 \\ \text { stijgend } & 24.000 \\ \text { stijgend } & 54.000\end{array}$

16.500

11.500

89.000

6.000

46.500

137.000

46.500

75.500

19.000

258.000

286.000

76.500

14.000

32.000

33.000

28.500

26.500

91.000

$\begin{array}{rlr}7.500 & \text { stijgend } & 8.500 \\ 15.500 & \text { constant } & 15.000 \\ & & \\ 36.500 & \text { constant } & 32.000 \\ 21.000 & \text { stijgend } & 21.000 \\ 17.000 & \text { constant } & 17.000 \\ 36.500 & \text { stijgend } & 37.500 \\ 39.000 & \text { constant } & 37.500 \\ 36.000 & \text { stijgend } & 35.500 \\ 8.000 & \text { constant } & 8.000 \\ 26.500 & \text { constant } & 27.500\end{array}$

124.500

26.000

33.500

31.000

13.500

10.000

$\begin{array}{lr}\text { constant } & 24.500 \\ \text { sterk stijgend } & 7.500\end{array}$

$\begin{array}{lr}\text { constant } & 24.500 \\ \text { sterk stijgend } & 7.500\end{array}$

8.500

5.000

2.000

37.500

7.500

8.000

27.500 


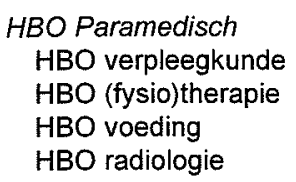

WO Landbouw en milieukunde WO landbouw en milieukunde

WO Techniek

WO wiskunde en natuurwetenschappen

WO bouwkunde

WO civiele techniek

WO werktuigbouwkunde

WO elektrotechniek

WO informatica en bestuurlijke informatiekunde

WO Medisch

WO (dier)geneeskunde

WO tandheelkunde

WO farmacie

\section{WO Economie}

WO econom(etr)ie

WO bedrijfskunde

WO accountancy en belastingen

WO rechten en bestuurskunde

$\begin{array}{rlr}51.000 & \text { stijgend } & 42.000 \\ 36.000 & \text { stijgend } & 29.500 \\ 4.500 & \text { stijgend } & 3.500 \\ 6.000 & - & 4.500\end{array}$

$\begin{array}{rlr}56.500 & \text { constant } & 55.500 \\ 42.000 & \text { stijgend } & 42.500 \\ 9.000 & \text { stijgend } & 8.000 \\ 23.500 & \text { stijgend } & 21.000 \\ 33.000 & \text { sterk dalend } & 28.000 \\ 59.500 & \text { sterk stijgend } & 58.000\end{array}$

14.000

75.500

sterk stijgend

13.000

19.000

constant

63.000

constant

17.500

13.500

stijgend

10.500

$44.000 \quad$ stijgend

37.500

$9.000 \quad$ constant

9.000

$\begin{array}{rlr}59.000 & \text { constant } & 56.000 \\ 9.500 & \text { dalend } & 9.500 \\ 7.000 & \text { constant } & 7.000 \\ 10.000 & \text { constant } & 10.000 \\ 9.500 & \text { constant } & 9.000 \\ 7.000 & \text { sterk stijgend } & 7.000\end{array}$

$\begin{array}{rlr}43.000 & \text { constant } & 47.000 \\ 6.000 & \text { stijgend } & 6.500 \\ 5.500 & \text { constant } & 6.000\end{array}$

$39.500 \quad$ stijgend $\quad 38.500$

$20.000 \quad$ sterk stijgend 20.000

16.500 stijgend 17.500

$58.000 \quad$ stijgend $\quad 56.000$ 
Tabel 3.1 (vervolg)

Aantal werkenden per opleidingstype, gemiddelde 1995-1996

Opleidingstype

\section{WO Sociaal-cultureel \\ WO sociale wetenschappen \\ WO Kunst \\ WO kunstwetenschappen}

Totaal aantal werkenden trend

1992-'96

arbeidsvolume

Bron: CBS/ROA

\section{Toelichting:}

Het aantal werkenden heeft betrekking op iedereen die jonger is dan 65 en minstens 12 uur per week werkt. Arbeidsvolume is het totaal aantal normaal gewerkte arbeidsjaren gedeeld door 40 . 
Tabel 3.2

Arbeidsmarktpositie potentiële beroepsbevolking naar opleidingstype, gemiddelde 1995-1996

\begin{tabular}{|c|c|c|c|}
\hline Opleidingstype & $\begin{array}{r}\text { werkzaam } \\
\%\end{array}$ & $\begin{array}{r}\text { werkloos } \\
\%\end{array}$ & $\begin{array}{r}\text { niet- } \\
\text { participerend } \\
\%\end{array}$ \\
\hline
\end{tabular}

\section{BASISONDERWIJS}

Basisonderwijs

MAVO, VBO

$$
\begin{aligned}
& \text { MAVO } \\
& \text { MAVO }
\end{aligned}
$$

VBO Landbouw en natuurlijke omgeving VBO landbouw en natuurlijke omgeving

VBO Techniek

VBO bouwtechniek

VBO installatietechniek

VBO mechanische techniek

VBO fijnmechanische techniek

VBO motorvoertuigentechniek

VBO elektrotechniek

VBO grafische techniek

VBO brood en banket

VBO horeca en levensmiddelentechniek

VBO vervoer

VBO Economie

VBO administratie, handel en textiel

47

VBO Verzorging

VBO verzorging

31

VBO Openbare orde en veiligheid

VBO beveiliging

HAVO/VWO, MBO/LLW

HAVONWO
HAVONWO

MBO/LLW Landbouw en natuurlike omgeving $\mathrm{MBO} / \mathrm{LLW}$ landbouw en veeteelt $\mathrm{MBO} / \mathrm{LLW}$ milieu en groene ruimte

\section{MBO/LLW Techniek}

MBO/LLW laboratorium

MBO/LLW bouw

MBO/LLW grond-, weg- en waterbouw

$\mathrm{MBO} / \mathrm{LLW}$ installatietechniek

4

6

MBO/LLW werktuigbouw en mechanische techniek

\section{8}

$26 \quad 418.000$

13.000 
Tabel 3.2 (vervolg)

Arbeidsmarktpositie potentiële beroepsbevolking naar opleidingstype, gemiddelde 1995-1996

\begin{tabular}{lrrr}
\hline & werkzaam & werkloos & $\begin{array}{c}\text { niet- } \\
\%\end{array}$ \\
Opleidingstype & $\%$ & participerend \\
$\%$
\end{tabular}

MBO/LLW grafische techniek

MBO/LLW procestechniek

81

MBO/LLW brood en banket

MBO/LLW levensmiddelentechniek/

vleesverwerking

MBO/LLW vervoer
$M B O / L L W$ Dienstverlening en gezondheidszorg

MBO dokters-, tandarts- en dierenartsassistent 65

MBO/LLW apothekersassistent

$\mathrm{MBO} / \mathrm{LW} W$ verpleging

MBO/LLW gezondheidstechniek

MBO sociaal-cultureel

$\mathrm{MBO} / \mathrm{LLW}$ verzorging

$\mathrm{MBO} / \mathrm{LLW}$ uiterlijke verzorging

MBO/LLW horeca

MBO/LLW beweging en therapie

\section{MBO/LLW Economie}

MBO/LLW administratie

MBO/LLW handel

MBO/LLW secretariaat

MBO/LLW toerisme en recreatie

MBO/LLW bedrijfskunde

MBO/LLW automatisering

MBO/LLW geld, bank en belastingen

$M B O$ verzekeringswezen

MBO Openbare orde en veiligheid

MBO openbare orde en veiligheid

\section{4}

63

87

71

52

57

77

66

\section{5}

68

61

86

85

85

82

87

82
48.500

26.000

17.500

27.000

13

13

63.500

34.500

25.000

197.500

7.000

79.500

366.000

100.500

94.000

36.500

367.500

417.500

159.500

18.500

38.000

40.500

38.000

30.000

16

113.500

HBO

HBO Onderwijs en tolk en vertaler

HBO lerarenopleiding basisonderwijs $\quad 70$

HBO lerarenopleiding talen $\quad 77$

HBO lerarenopleiding natuur en techniek 84

HBO lerarenopleiding economie en maatschappij 78

HBO lerarenopleiding lichamelijke opvoeding 80

$\mathrm{HBO}$ lerarenopleiding medisch en verzorging 61

HBO lerarenopleiding expressie 65

$\mathrm{HBO}$ tolk en vertaler

HBO Landbouw

HBO landbouw en veeteelt

HBO milieukunde en levensmiddelentechnologie 87

$\begin{array}{lr}27 & 214.500 \\ 20 & 40.000 \\ 13 & 43.000 \\ 18 & 45.500 \\ 18 & 18.000 \\ 35 & 22.000 \\ 29 & 45.000 \\ 37 & 14.000\end{array}$

HBO Techniek

HBO laboratorium

HBO bouwkunde

HBO civiele techniek

HBO werktuigbouwkunde $\quad 87$

HBO elektrotechniek $\quad 87$

$\mathrm{HBO}$ informatica 
Tabel 3.2 (vervolg)

Arbeidsmarktpositie potentiële beroepsbevolking naar opleidingstype, gemiddelde 1995-1996

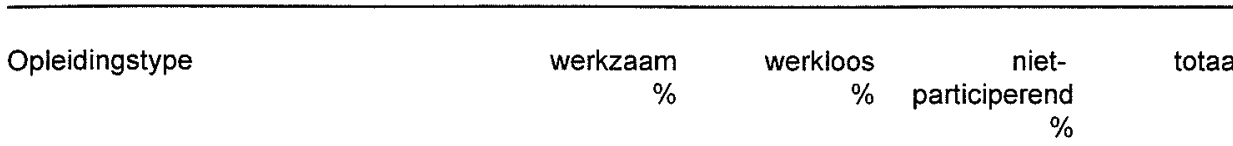

HBO chemische technologie

$\mathrm{HBO}$ vervoer en logistiek

83

79

82

HBO Paramedisch

$\mathrm{HBO}$ verpleegkunde

HBO (fysio)therapie

$\mathrm{HBO}$ voeding

$\mathrm{HBO}$ radiologie

\section{HBO Economie}

$\mathrm{HBO}$ accountancy en bedrijfseconomie

HBO commerciële economie

$\mathrm{HBO}$ toerisme en recreatie

$\mathrm{HBO}$ recht en bestuur

HBO secretariaat

$\mathrm{HBO}$ bedrijfskunde

HBO Sociaal-cultureel

HBO communicatie en journalistiek 88

HBO maatschappelijk werk en hulpverlening 78

HBO personeelswerk

HBO bibliotheek en documentatie

87

HBO Kunst

HBO uitvoerende en beeldende kunsten

HBO Openbare orde en veiligheid

HBO openbare orde en veiligheid

80

88

90

78

88

73

90

7

4

wo

WO Letteren en theologie

WO letteren

WO theologie

82

89

WO Landbouw en milieukunde

WO landbouw en milieukunde

87

85

WO wiskunde en natuurwetenschappen

WO bouwkunde

WO civiele techniek

WO werktuigbouwkunde

WO elektrotechniek

WO informatica en bestuurlijke informatiekunde

WO Medisch

WO (dier)geneeskunde

WO tandheelkunde

WO farmacie

89

95

90

WO Economie

WO econom(etr)ie

WO bedrijfskunde

3

$\begin{array}{rr}- & 9.500 \\ 16 & 33.000\end{array}$

9.500

$\begin{array}{ll}14 & 61.500 \\ 16 & 44.500\end{array}$

- 6.000

- 8.500

1

62.000

$6 \quad 46.500$

- $\quad 11.000$

- 24.000

$22 \quad 44.500$

$6 \quad 64.500$

4

15.500

96.000

22.000

$16 \quad 17.000$

$21 \quad 55.500$

11.500

$-11.500$ 
Tabel 3.2 (vervolg)

Arbeidsmarktpositie potentiële beroepsbevolking naar opleidingstype, gemiddelde 1995-1996

\begin{tabular}{|c|c|c|c|c|}
\hline Opleidingstype & $\begin{array}{r}\text { werkzaam } \\
\%\end{array}$ & $\begin{array}{r}\text { werkloos } \\
\%\end{array}$ & $\begin{array}{r}\text { niet- } \\
\text { participerend } \\
\%\end{array}$ & totaal \\
\hline WO accountancy en belastingen & 94 & - & - & 17.500 \\
\hline WO rechten en bestuurskunde & 87 & 6 & 7 & 64.500 \\
\hline \multicolumn{5}{|l|}{ wo Sociaal-cultureel } \\
\hline WO sociale wetenschappen & 85 & 7 & 8 & 94.500 \\
\hline \multicolumn{5}{|l|}{ WO Kunst } \\
\hline WO kunstwetenschappen & 75 & - & - & 7.000 \\
\hline Totaal & 65 & 5 & 30 & 9.262 .000 \\
\hline
\end{tabular}

Bron: CBS/ROA

\section{Toelichting:}

De potentiële beroepsbevolking betreft alle mensen die ouder zijn dan 15 en jonger dan 64, uitgezonderd studenten/scholieren in het regulier onderwijs. Het percentage werkloos is de werkloze beroepsbevolking als percentage van de potentiële beroepsbevolking, hetgeen niet verward moet worden met het gebruikelijke werkloosheidspercentage waarin de werkloosheid gerelateerd wordt aan de beroepsbevolking. 
Tabe/ 3.3

Participatie schoolverlaters in vervolgopleidingen per opleidingsrichting, 1996

\begin{tabular}{lccc}
\hline Opleidingstype & $\substack{\text { studie } \\
\%}$ & typering & LLW/Inservice \\
$\%$ & typering
\end{tabular}

VBO, MAVO

MAVO

MAVO

VBO Landbouw en natuurlijke omgeving

VBO landbouw en natuurlijke omgeving

VBO Techniek

VBO bouwtechniek

VBO mechanische techniek

VBO motorvoertuigentechniek

VBO elektrotechniek

VBO horeca en levensmiddelentechniek

VBO Economie

VBO administratie, handel en textiel

56

erg hoog

5

gemiddeld

VBO Verzorging

VBO verzorging

58

erg hoog

12

gemiddeld

MBO, HAVONWO

HAVONWO
HAVONWO

87

erg hoog

2

laag

MBO landbouw en natuurlijke omgeving

- KMBO landbouw en veeteelt

KMBO milieu en groene ruimte

$\mathrm{MBO}$ landbouw en veeteelt

MBO milieu en groene ruimte

MBO Techniek

KMBO bouw

KMBO grond-, weg- en waterbouw

KMBO werktuigbouw en mechanische techniek

KMBO motorvoertuigentechniek

KMBO elektrotechniek

KMBO brood en banket

MBO bouw

MBO grond-, weg- en waterbouw

$\mathrm{MBO}$ installatietechniek

MBO werktuigbouw en mechanische techniek

MBO motorvoertuigentechniek

MBO elektrotechniek

MBO grafische techniek

laag

gemiddeld

gemiddeld

gemiddeld

gemiddeld

gemiddeld

gemiddeld

gemiddeld

gemiddeld

laag

hoog

hoog

laag

hoog

laag

hoog

gemiddeld

hoog

hoog

MBO levensmiddelentechniek/vleesverwerking

MBO Dienstverlening en gezondheidszorg

KMBO verzorging

KMBO horeca

hoog

gemidideld

gemiddeld

laag

MBO apothekersassistent

$M B O$ verpleging

MBO sociaal-cultureel gemiddeld

hoog
7

12

gemiddeld

hoog

hoog

hoog

hoog

erg hoog

31 
Tabel 3.3 (vervolg)

Participatie schoolverlaters in vervolgopleidingen per opleidingsrichting, 1996

\begin{tabular}{|c|c|c|c|c|}
\hline Opleidingstype & $\begin{array}{c}\text { studie } \\
\%\end{array}$ & typering & $\begin{array}{c}\text { LLW/Inservice } \\
\%\end{array}$ & typering \\
\hline MBO verzorging & 21 & gemiddeld & 3 & laag \\
\hline MBO uiterlijke verzorging & 4 & laag & 2 & laag \\
\hline MBO horeca & 26 & gemiddeld & 0 & erg laag \\
\hline MBO beweging en therapie & 20 & gemiddeld & 4 & gemiddeld \\
\hline \multicolumn{5}{|l|}{ MBO Economie } \\
\hline KMBO administratie & 28 & gemiddeld & 7 & gemiddeld \\
\hline KMBO handel & 30 & gemiddeld & 8 & gemiddeld \\
\hline MBO administratie & 35 & hoog & 1 & erg laag \\
\hline MBO handel & 30 & gemiddeld & 2 & laag \\
\hline MBO toerisme en recreatie & 17 & gemiddeld & 1 & erg laag \\
\hline
\end{tabular}

HBO

HBO Onderwijs en tolk en vertaler HBO lerarenopleiding basisonderwijs 9 $\mathrm{HBO}$ lerarenopleiding talen 23 HBO lerarenopleiding natuur en techniek $\quad 15$ HBO lerarenopleiding expressie 18 $\mathrm{HBO}$ tolk en vertaler

laag gemiddeld gemiddeld gemiddeld hoog

\section{HBO Landbouw}

$\mathrm{HBO}$ landbouw en veeteelt $\quad 13$

HBO milieukunde en levensmiddelentechnologie 14

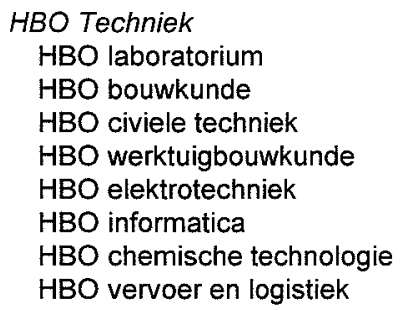

laag

gemiddeld gemiddeld laag

laag

laag gemiddeld gemiddeld

gemiddeld

gemiddeld gemiddeld gemiddeld gemiddeld laag gemiddeld

n.v.t.

n.v.t. 
Tabel 3.3 (vervolg)

Participatie schoolverlaters in vervolgopleidingen per opleidingsrichting, 1996

Opleidingstype studie typering

LLW/Inservice

typering

$\%$ $\%$

\section{HBO Kunst}

HBO uitvoerende en beeldende kunsten

$8 \quad$ laag

\section{wo}

\section{WO Economie}

WO econom(etr)ie

WO bedrijfskunde

WO accountancy en belastingen

$\begin{array}{ll}2 & \text { erg laag } \\ 2 & \text { erg laag } \\ 0 & \text { erg laag }\end{array}$

Bron: ROA (schoolverlatersenquêtes RUBS, HBO-Monitor, WO-economie scanner) 
Tabe/ 3.4

Percentage schoolverlaters met een intredewerkloosheid van 4 maanden of langer per opleidingsrichting, 1996

\begin{tabular}{llc}
\hline Opleidingstype & $\%$ & typering \\
\hline
\end{tabular}

VBO, MAVO

MAVO

MAVO

VBO Landbouw en natuurlijke omgeving

VBO landbouw en natuurlijke omgeving

VBO Techniek

VBO bouwtechniek

VBO mechanische techniek

VBO motorvoertuigentechniek

VBO elektrotechniek

VBO horeca en levensmiddelentechniek

VBO Economie

VBO administratie, handel en textiel

VBO Verzorging

VBO verzorging

MBO, HAVO/VWO

\section{HAVONWO \\ HAVONWO}

MBO landbouw en natuurlijke omgeving

$\mathrm{KMBO}$ landbouw en veeteelt

KMBO milieu en groene ruimte

$\mathrm{MBO}$ landbouw en veeteelt

MBO milieu en groene ruimte

MBO Techniek

KMBO bouw

KMBO grond-, weg- en waterbouw

$\mathrm{KMBO}$ werktuigbouw en mechanische techniek

KMBO motorvoertuigentechniek

KMBO elektrotechniek

KMBO brood en banket

MBO bouw

MBO grond-, weg- en waterbouw

MBO installatietechniek

MBO werktuigbouw en mechanische techniek

MBO motorvoertuigentechniek

MBO elektrotechniek

MBO grafische techniek

MBO procestechniek

MBO levensmiddelentechniek/vleesverwerking

MBO Dienstverlening en gezondheidszorg

$\mathrm{KMBO}$ verzorging

$\mathrm{KMBO}$ horeca

MBO dokters-, tandarts- en dierenartsassistent

MBO apothekersassistent

$M B O$ verpleging erg laag

11

gemiddeld

12

$-$

$-$

19

22

erg hoog

13

gemiddeld

8

laag

24

$-$

7

9

erg hoog

laag

gemiddeld

36

erg hoog

28

$-$

12

$-$

8

2

0

3

21

7

10

16

10

30

3

9

7

8 erg hoog

gemiddeld

-

laag

erg laag

erg laag

erg laag

hoog

laag

gemiddeld

hoog

gemiddeld

erg hoog

erg laag

gemiddeld

laag

laag 
Tabe/ 3.4 (vervolg)

Percentage schoolverlaters met een intredewerkloosheid van 4 maanden of langer per opleidingsrichting, 1996

\begin{tabular}{lcl}
\hline Opleidingstype & $\%$ & typering \\
\hline & 13 & gemiddeld \\
MBO sociaal-cultureel & 16 & hoog \\
MBO verzorging & 14 & gemiddeld \\
MBO uiterlijke verzorging & 2 & erg laag \\
MBO horeca & 13 & gemiddeld \\
MBO beweging en therapie & & \\
& & hoog \\
MBO Economie & 16 & erg hoog \\
KMBO administratie & 25 & laag \\
KMBO handel & 8 & gemiddeld \\
MBO administratie & 11 & gemiddeld \\
MBO handel & 10 & \\
MBO toerisme en recreatie & &
\end{tabular}

HBO

HBO Onderwijs en tolk en vertaler HBO lerarenopleiding basisonderwijs $\quad 12$ HBO lerarenopleiding talen $\quad 12$ HBO lerarenopleiding natuur en techniek $\quad 10$ HBO lerarenopleiding expressie $\quad 22$ $\mathrm{HBO}$ tolk en vertaler

gemiddeld gemiddeld gemiddeld erg hoog erg hoog

HBO Landbouw

HBO landbouw en veeteelt $\quad 10$

HBO milieukunde en levensmiddelentechnologie $\quad 19$

gemiddeld

hoog

\section{HBO Techniek $\mathrm{HBO}$ laboratorium $\mathrm{HBO}$ bouwkunde HBO civiele techniek HBO werktuigbouwkunde HBO elektrotechniek HBO informatica $\mathrm{HBO}$ chemische technologie $\mathrm{HBO}$ vervoer en logistiek}

16

3

3

8

11

6

17

7

HBO Paramedisch

$\mathrm{HBO}$ verpleegkunde

HBO (fysio)therapie

$\mathrm{HBO}$ voeding

$\mathrm{HBO}$ radiologie

HBO Economie

$\mathrm{HBO}$ accountancy en bedrijfseconomie

HBO commerciële economie

$\mathrm{HBO}$ toerisme en recreatie

HBO recht en bestuur

HBO secretariaat

HBO bedriffskunde

HBO Sociaal-cultureel

$\mathrm{HBO}$ communicatie en journalistiek

HBO maatschappelijk werk en hulpverlening

HBO personeelswerk

HBO bibliotheek en documentatie

HBO sociaal-cultureel overig

9

hoog erg laag erg laag

laag gemiddeld laag hoog laag

erg laag hoog gemiddeld erg laag

erg laag laag gemiddeld hoog laag gemiddeld

gemiddeld gemiddeld gemiddeld gemiddeld gemiddeld 
Tabel 3.4 (vervolg)

Percentage schoolverlaters met een intredewerkloosheid van 4 maanden of langer per opleidingsrichting, 1996

\begin{tabular}{lll}
\hline Opleidingstype & $\%$ & typering
\end{tabular}

\section{HBO Kunst}

HBO uitvoerende en beeldende kunsten

29

erg hoog

wo

WO Economie

WO econom(etr)ie

WO bedrijfskunde

WO accountancy en belastingen

Bron: ROA (schoolverlatersenquêtes RUBS, HBO-Monitor, WO-economie scanner)

Toelichting:

Het percentage is gemeten in procenten van de schoolverlaters die tot de beroepsbevolking behoren. Onder intredewerkloosheid wordt het totaal aantal maanden verstaan dat schoolverlaters sinds het verlaten van de opleiding als maatschappelijke positie werkloos hebben opgegeven. 
Tabel 3.5

Werkloosheid onder schoolverlaters per opleidingsrichting, percentages, 1996

\begin{tabular}{llc}
\hline Opleidingstype & $\%$ & typering \\
\hline
\end{tabular}

VBO, MAVO

MAVO

MAVO

10

hoog

VBO Landbouw en natuurlijke omgeving

VBO landbouw en natuurlijke omgeving

4

laag

VBO Techniek

VBO bouwtechniek

VBO mechanische techniek

VBO motorvoertuigentechniek

VBO elektrotechniek

VBO horeca en levensmiddelentechniek

VBO Economie

VBO administratie, handel en textiel

gemiddeld

erg hoog

VBO Verzorging

erg hoog

VBO verzorging

MBO, HAVOIVWO

\section{HAVONWO}

HAVONWO

MBO landbouw en natuurlijke omgeving

$\mathrm{KMBO}$ landbouw en veeteelt

KMBO milieu en groene ruimte

$M B O$ landbouw en veeteelt

MBO milieu en groene ruimte

18

12

3

6

MBO Techniek

KMBO bouw

KMBO grond-, weg-en waterbouw

KMBO werktuigbouw en mechanische techniek

KMBO motorvoertuigentechniek

KMBO elektrotechniek

KMBO brood en banket

MBO bouw

MBO grond-, weg- en waterbouw

MBO installatietechniek

MBO werktuigbouw en mechanische techniek

$\mathrm{MBO}$ motorvoertuigentechniek

MBO elektrotechniek

MBO grafische techniek

MBO procestechniek

MBO levensmiddelentechniek/vleesverwerking

erg hoog

\section{MBO Dienstverlening en gezondheidszorg}

\section{KMBO verzorging}

KMBO horeca

MBO dokters-, tandarts- en dierenartsassistent

MBO apothekersassistent

$M B O$ verpleging

MBO sociaal-cultureel hoog

3

erg hoog

hoog

laag

gemiddeld

erg hoog

erg hoog

laag

-

gemiddeld

laag

erg laag

erg laag

laag

erg hoog

laag

hoog

gemiddeld

hoog

hoog

laag

gemiddeld

gemiddeld

gemiddeld

hoog 
Tabe/ 3.5 (vervolg)

Werkloosheid onder schoolverlaters per opleidingsrichting, percentages, 1996

\begin{tabular}{|c|c|c|}
\hline Opleidingstype & $\%$ & typering \\
\hline MBO verzorging & 5 & laag \\
\hline MBO uiterlijke verzorging & 13 & hoog \\
\hline MBO horeca & 4 & laag \\
\hline MBO beweging en therapie & 7 & gemiddeld \\
\hline \multicolumn{3}{|l|}{ MBO Economie } \\
\hline KMBO administratie & 13 & hoog \\
\hline KMBO handel & 10 & hoog \\
\hline MBO administratie & 6 & gemiddeld \\
\hline MBO handel & 8 & gemiddeld \\
\hline MBO toerisme en recreatie & 5 & laag \\
\hline \multicolumn{3}{|l|}{$\mathrm{HBO}$} \\
\hline \multicolumn{3}{|l|}{ HBO Onderwijs en tolk en vertaler } \\
\hline HBO lerarenopleiding basisonderwijs & 8 & gemiddeld \\
\hline HBO lerarenopleiding talen & 8 & gemiddeld \\
\hline HBO lerarenopleiding natuur en techniek & 7 & gemiddeld \\
\hline HBO lerarenopleiding expressie & 13 & hoog \\
\hline HBO tolk en vertaler & 12 & hoog \\
\hline \multicolumn{3}{|l|}{ HBO Landbouw } \\
\hline HBO landbouw en veeteelt & 6 & gemiddeld \\
\hline HBO milieukunde en levensmiddelentechnologie & 12 & hoog \\
\hline \multicolumn{3}{|l|}{ HBO Techniek } \\
\hline HBO laboratorium & 10 & hoog \\
\hline HBO bouwkunde & 1 & erg laag \\
\hline HBO civiele techniek & 2 & erg laag \\
\hline HBO werktuigbouwkunde & 7 & gemiddeld \\
\hline HBO elektrotechniek & 6 & gemiddeld \\
\hline HBO informatica & 2 & erg laag \\
\hline HBO chemische technologie & 12 & hoog \\
\hline HBO vervoer en logistiek & 8 & gemiddeld \\
\hline \multicolumn{3}{|l|}{ HBO Paramedisch } \\
\hline HBO verpleegkunde & 2 & erg laag \\
\hline HBO (fysio)therapie & 11 & hoog \\
\hline HBO voeding & 3 & laag \\
\hline HBO radiologie & 3 & laag \\
\hline \multicolumn{3}{|l|}{ HBO Economie } \\
\hline HBO accountancy en bedrijfseconomie & 2 & erg laag \\
\hline HBO commerciële economie & 5 & laag \\
\hline HBO toerisme en recreatie & 8 & gemiddeld \\
\hline HBO recht en bestuur & 11 & hoog \\
\hline HBO secretariaat & 5 & laag \\
\hline HBO bedrijfskunde & 4 & laag \\
\hline \multicolumn{3}{|l|}{ HBO Sociaal-cultureel } \\
\hline HBO communicatie en journalistiek & 5 & laag \\
\hline HBO maatschappelijk werk en hulpverlening & 9 & gemiddeld \\
\hline HBO personeelswerk & 4 & laag \\
\hline HBO bibliotheek en documentatie & 6 & gemiddeld \\
\hline HBO sociaal-cultureel overig & 3 & laag \\
\hline
\end{tabular}


Tabel 3.5 (vervolg)

Werkloosheid onder schoolverlaters per opleidingsrichting, percentages, 1996

\begin{tabular}{lll}
\hline Opleidingstype & $\%$ & typering
\end{tabular}

HBO Kunst

HBO uitvoerende en beeldende kunsten

20

erg hoog

wo

\section{WO Economie}

WO econom(etr)ie

WO bedrijfskunde

WO accountancy en belastingen

$\begin{array}{ll}4 & \text { laag } \\ 4 & \text { laag } \\ 8 & \text { gemiddeld }\end{array}$

Bron: ROA (schoolverlatersenquêtes RUBS, HBO-Monitor, WO-economie scanner)

Toelichting:

Het percentage is gemeten in procenten van de schoolverlaters die tot de beroepsbevolking behoren. 
Tabe/ 3.6

Percentage vrouwen per opleidingstype, gemiddelde 1995-1996

Opleidingstype

$\%$

typering

trend

1992-'96

\section{BASISONDERWIJS}

Basisonderwijs

gemiddeld

constant

MAVO, VBO

MAVO

gemiddeld

constant

VBO Landbouw en natuurlijke omgeving

VBO landbouw en natuurlijke omgeving

9

VBO Techniek

VBO bouwtechniek

VBO installatietechniek

VBO mechanische techniek

VBO fijnmechanische techniek

VBO motorvoertuigentechniek

VBO elektrotechniek

VBO grafische techniek

VBO brood en banket

VBO horeca en levensmiddelentechniek

VBO vervoer

VBO Economie

VBO administratie, handel en textiel

VBO Verzorging

VBO verzorging

VBO Openbare orde en veiligheid

VBO beveiliging

HAVO/WWO, MBO/LLW

HAVONWO

HAVONWO

MBO/LLW Landbouw en natuurlijke omgeving

$\mathrm{MBO} / \mathrm{LLW}$ landbouw en veeteelt

$\mathrm{MBO} / \mathrm{LL} W$ milieu en groene ruimte

MBO/LLW Techniek

MBO/LLW laboratorium

MBO/LLW bouw

MBO/LLW grond-, weg- en waterbouw

MBO/LLW installatietechniek

MBO/LLW werktuigbouw en mechanische techniek

MBO/LLW fijnmechanische techniek

MBO/LLW motorvoertuigentechniek

$\mathrm{MBO} / \mathrm{LLW}$ vliegtuigtechniek

MBO/LLW operationele techniek

MBO/LLW elektrotechniek

MBO/LLW grafische techniek

$\mathrm{MBO} / \mathrm{LLW}$ procestechniek
46

13

49 laag

erg laag
erg laag
erg laag
erg laag
erg laag
erg laag
laag
erg laag
gemiddeld
erg laag

constant

$-$

sterk stijgend constant

constant sterk dalend

constant

constant

laag

sterk stijgend

gemiddeld constant

gemiddeld stijgend

laag

constant

$\begin{array}{ll}\text { gemiddeld } & \text { stijgend } \\ \text { erg laag } & \text { sterk stijgend } \\ \text { erg laag } & - \\ \text { erg laag } & - \\ \text { erg laag } & - \\ \text { gemiddeld } & - \\ \text { erg laag } & \text { sterk stijgend } \\ \text { erg laag } & - \\ \text { erg laag } & - \\ \text { erg laag } & - \\ \text { gemiddeld } & - \\ \text { erg laag } & \text { sterk dalend }\end{array}$


$\mathrm{MBO} / \mathrm{LLW}$ brood en banket

MBO/LLW levensmiddelentechniek/vleesverwerking MBO/LLW vervoer

MBO/LLW Dienstverlening en gezondheidszorg

MBO dokters-, tandarts- en dierenartsassistent

MBO/LLW apothekersassistent

$\mathrm{MBO} / \mathrm{LLW}$ verpleging

MBO/LLW gezondheidstechniek

MBO sociaal-cultureel

MBO/LLW verzorging

MBO/LLW uiterlijke verzorging

MBO/LLW horeca

MBO/LLW beweging en therapie

95

98

86

-

69

94

88

29

69
MBO/LLW Economie
MBO/LLW administratie
MBO/LLW handel
MBO/LLW secretariaat
MBO/LLW toerisme en recreatie
MBO/LLW bedrijfskunde
MBO/LLW automatisering
MBO/LLW geld, bank en belasting
MBO verzekeringswezen
MBO Openbare orde en veiligheid
MBO openbare orde en veiligheid

HBO

HBO Onderwijs en tolk en vertaler $\mathrm{HBO}$ lerarenopleiding basisonderwijs

$\mathrm{HBO}$ lerarenopieiding talen

HBO lerarenopleiding natuur en techniek

HBO lerarenopleiding economie en maatschappij

HBO lerarenopleiding lichamelijke opvoeding

$\mathrm{HBO}$ lerarenopleiding medisch en verzorging

$\mathrm{HBO}$ lerarenopleiding expressie

HBO tolk en vertaler

HBO Landbouw

$\mathrm{HBO}$ landbouw en veeteelt

HBO milieukunde en levensmiddelentechnologie

HBO Techniek

$\mathrm{HBO}$ laboratorium

HBO bouwkunde

HBO civiele techniek

$\mathrm{HBO}$ werktuigbouwkunde

HBO elektrotechniek

$\mathrm{HBO}$ informatica

HBO chemische technologie

HBO vervoer en logistiek laag

gemiddeld

gemiddeld

constant

sterk stijgend

constant

$\begin{array}{ll}\text { erg hoog } & \text { constant } \\ \text { erg hoog } & \text { constant } \\ \text { erg hoog } & \text { constant } \\ \text { gemiddeld } & \text { constant } \\ \text { hoog } & \text { constant } \\ \text { erg hoog } & \text { constant } \\ \text { erg hoog } & \text { constant } \\ \text { gemiddeld } & \text { stijgend } \\ \text { hoog } & \text { constant }\end{array}$

gemiddeld gemiddeld

erg hoog

erg hoog

gemiddeld

gemiddeld

gemiddeld

gemiddeld

constant

constant

constant

constant

stijgend

-

stijgend

-

laag

sterk stijgend

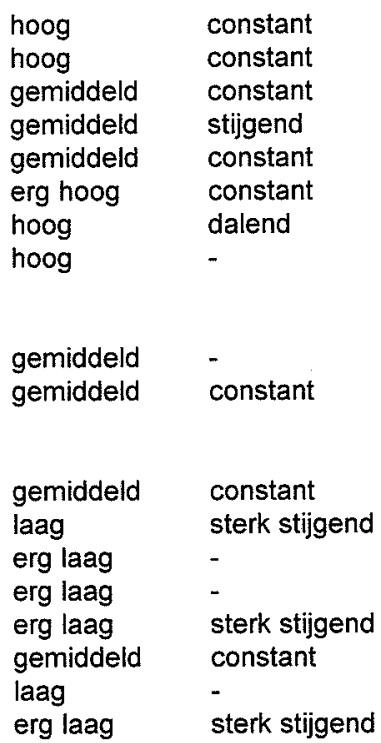


Tabel 3.6 (vervolg)

Percentage vrouwen per opleidingstype, gemiddelde 1995-1996

Opleidingstype $\quad \% \quad$ typering trend

HBO Paramedisch
HBO verpleegkunde
HBO (fysio)therapie
HBO voeding
HBO radiologie
HBO Economie

HBO accountancy en bedrijfseconomie $\quad 16$

HBO commerciële economie $\quad 25$

$\mathrm{HBO}$ toerisme en recreatie $\quad 84$

HBO recht en bestuur $\quad 29$

HBO secretariaat $\quad 97$

HBO bedrijfskunde $\quad 28$

HBO Sociaal-cultureel

HBO communicatie en journalistiek 58

HBO maatschappelijk werk en hulpverlening 62

HBO personeelswerk $\quad 40$

HBO bibliotheek en documentatie

HBO Kunst

$\mathrm{HBO}$ uitvoerende en beeldende kunsten

HBO Openbare orde en veiligheid

HBO openbare orde en veiligheid

\section{WO}

WO Letteren en theologie

WO letteren

WO theologie

WO Landbouw en milieukunde

WO landbouw en milieukunde

WO Techniek

WO wiskunde en natuurwetenschappen

WO bouwkunde

WO civiele techniek

WO werktuigbouwkunde

WO elektrotechniek

WO informatica en bestuurlijke informatiekunde

WO Medisch

WO (dier)geneeskunde

WO tandheelkunde

WO farmacie

WO Economie

WO econom(etr)ie

WO bedrijfskunde

WO accountancy en belastingen

WO rechten en bestuurskunde
44

17

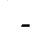

$-$

$-$

$-$

$-$

\section{4}

70

94

78

(2)

$\begin{array}{ll}\text { hoog } & \text { constant } \\ \text { hoog } & \text { constant } \\ \text { erg hoog } & \text { constant } \\ \text { hoog } & \text { constant }\end{array}$

$\begin{array}{ll}\text { gemiddeld } & \text { stijgend } \\ \text { gemiddeld } & \text { stijgend } \\ \text { hoog } & \text { constant } \\ \text { gemiddeld } & \text { sterk stijgend } \\ \text { erg hoog } & \text { constant } \\ \text { gemiddeld } & \text { stijgend }\end{array}$

$\begin{array}{ll}\text { hoog } & \text { sterk stijgend } \\ \text { hoog } & \text { constant } \\ \text { gemiddeld } & \text { stijgend } \\ \text { hoog } & \text { constant }\end{array}$

gemiddeld stijgend

erg laag

gemiddeld constant
gemiddeld
gemiddeld stijgend

\begin{tabular}{|c|c|c|}
\hline 31 & $\begin{array}{l}\text { gemiddeld } \\
\text { gemiddeld } \\
\text { gemiddeld }\end{array}$ & $\begin{array}{l}\text { stijgend } \\
\text { sterk stijgend } \\
\text { sterk stijgend }\end{array}$ \\
\hline $\begin{array}{l}17 \\
18 \\
14 \\
36\end{array}$ & $\begin{array}{l}\text { gemiddeld } \\
\text { gemiddeld } \\
\text { gemiddeld } \\
\text { gemiddeld }\end{array}$ & $\begin{array}{l}\text { stijgend } \\
\text { stijgend } \\
\text { sterk stijge } \\
\text { constant }\end{array}$ \\
\hline
\end{tabular}


Tabe/ 3.6 (vervolg)

Percentage vrouwen per opleidingstype, gemiddelde 1995-1996

\begin{tabular}{lccc} 
Opleidingstype & $\%$ & typering & $\begin{array}{c}\text { trend } \\
1992-' 96\end{array}$ \\
\hline $\begin{array}{l}\text { WO Sociaal-cultureel } \\
\text { WO sociale wetenschappen }\end{array}$ & 49 & gemiddeld & stijgend \\
$\begin{array}{l}\text { WO Kunst } \\
\text { WO kunstwetenschappen }\end{array}$ & 54 & hoog & stijgend \\
\begin{tabular}{l} 
Totaal \\
\hline
\end{tabular} & 37 & gemiddeld & constant \\
\hline
\end{tabular}

Bron: CBS/ROA 


\section{BASISONDERWIJS}

Basisonderwijs

MAVO, VBO

MAVO
MAVO

VBO landbouw en natuurlijke omgeving VBO landbouw en natuurlijke omgeving

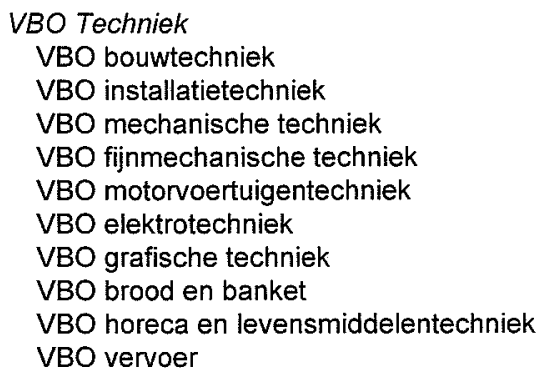

VBO Economie VBO administratie, handel en textiel $\checkmark B O$ verzorging VBO verzorging

VBO Openbare orde en veiligheid $\mathrm{VBO}$ beveiliging

\section{HAVO/NWO, MBO/LLW}

\section{HAVONWO HAVONWO}

MBO/LLW Landbouw en natuurlijke omgeving $\mathrm{MBO} / \mathrm{LLW}$ landbouw en veeteelt $\mathrm{MBO} / \mathrm{LLW}$ milieu en groene ruimte

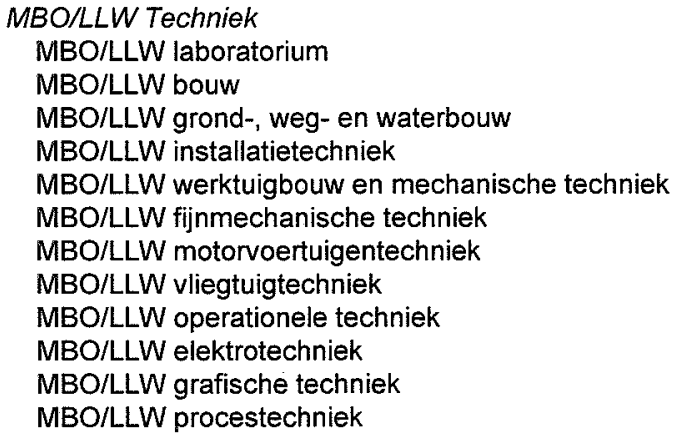

erg hoog

stijgend

erg hoog

constant

erg laag

sterk dalend

laag

gemiddeld

hoog

gemiddeld

hoog

hoog

laag

erg laag

gemiddeld

gemiddeld

sterk dalend

sterk dalend

-

constant

constant

constant

hoog

gemiddeld

gemiddeld

hoog

stijgend

erg laag

laag

gemiddeld

laag

laag

laag

gemiddeld

laag

gemiddeld

laag

gemiddeld

gemiddeld

laag

gemiddeld sterk stijgend

-

-

stijgend

-

sterk stijgend

- 
MBO/LLW brood en banket

MBO/LLW levensmiddelentechniek/vleesverwerking $\mathrm{MBO} / \mathrm{LLW}$ vervoer

MBO/LLW Dienstverlening en gezondheidszorg MBO dokters-, tandarts- en dierenartsassistent MBO/LLW apothekersassistent $M B O / L L W$ verpleging MBO/LLW gezondheidstechniek MBO sociaal-cultureel MBO/LLWW verzorging MBO/LLW uiterlijke verzorging $\mathrm{MBO} / \mathrm{LLW}$ horeca MBO/LLW beweging en therapie

\section{MBO/LLW Economie} MBO/LLW administratie $\mathrm{MBO} / \mathrm{LLW}$ handel $\mathrm{MBO} / L L W$ secretariaat MBO/LLW toerisme en recreatie MBO/LLW bedrijfskunde MBO/LLW automatisering MBO/LLW geld, bank en belastingen $M B O$ verzekeringswezen

MBO Openbare orde en veiligheid MBO openbare orde en veiligheid

HBO

HBO Onderwijs en tolk en vertaler HBO lerarenopleiding basisonderwijs HBO lerarenopleiding talen $\mathrm{HBO}$ lerarenopleiding natuur en techniek HBO lerarenopleiding economie en maatschappij $\mathrm{HBO}$ lerarenopleiding lichamelijke opvoeding $\mathrm{HBO}$ lerarenopleiding medisch en verzorging HBO lerarenopleiding expressie $\mathrm{HBO}$ tolk en vertaler

\section{HBO Landbouw} HBO landbouw en veeteelt HBO milieukunde en levensmiddelentechnologie erg laag

laag

gemiddeld

laag gemiddeld laag hoog gemiddeld gemiddeld gemiddeld gemiddeld hoog

sterk stijgend sterk stijgend sterk stijgend sterk stijgend

hoog
laag
gemiddeld
gemiddeld
gemiddeld
gemiddeld
gemiddeld
laag

sterk stijgend

-

$-$

constant

-

gemiddeld

constant

gemiddeld
gemiddeld
gemiddeld
laag
laag
laag
laag
gemiddeld

dalend

-

sterk dalend

-

-

-

erg laag

erg laag

laag

laag

erg laag

laag

gemiddeld sterk stijgend

gemiddeld

erg laag

gemiddeld 


\section{HBO Paramedisch $\mathrm{HBO}$ verpleegkunde HBO (fysio)therapie $\mathrm{HBO}$ voeding HBO radiologie}

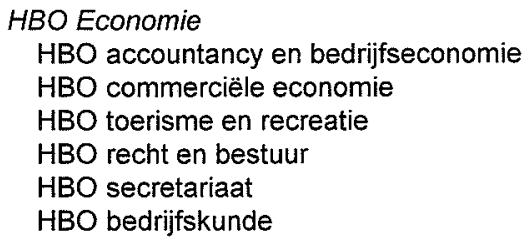

gemiddeld
laag -
erg laag
erg laag

gemiddeld

laag

laag

gemiddeld

laag

gemiddeld

erg laag

gemiddeld

gemiddeld

constant

gemiddeld

-

$-$

gemiddeld

gemiddeld

laag

laag

constant

gemiddeld

laag

hoog

erg laag

erg laag

hoog

erg laag

gemiddeld

erg laag

erg hoog

gemiddeld gemiddeld sterk dalend erg laag laag 
Tabel 3.7 (vervolg)

Percentage allochtonen per opleidingstype, gemiddelde 1995-1996

$\begin{array}{llll}\text { Opleidingstype } & \% & \text { typering } & \text { trend } \\ 1992-96\end{array}$

\title{
WO Sociaal-cultureel
}

WO sociale wetenschappen

$\cdot \cdot$

1992-'96

\author{
WO Kunst \\ WO kunstwetenschappen
}

Totaal

$\begin{array}{lll}- & \text { gemiddeld } & - \\ - & \text { hoog } & - \\ 3 & \text { gemiddeld } & \text { stijgend }\end{array}$

Bron: CBS/ROA

\section{Toelichting:}

Het percentage allochtonen heeft betrekking op iedereen die een niet-Nederlandse nationaliteit bezit, of die buiten Nederland is geboren, in één van de landen die genoemd worden in de Wet Bevordering Evenredige Arbeidsdeelname Allochtonen (WBEAA). Deze landen zijn: Aruba, Nederlandse Antillen, Ethiopië, Irak, Iran, voormalige Joegoslavië, Marokko, Somalië, Suriname, Turkijke en Vietnam. Op grond van deze wet zouden echter ook kinderen van allochtonen tot de doelgroep gerekend moeten worden, ongeacht of zij een nietNederlandse nationaliteit bezitten. 


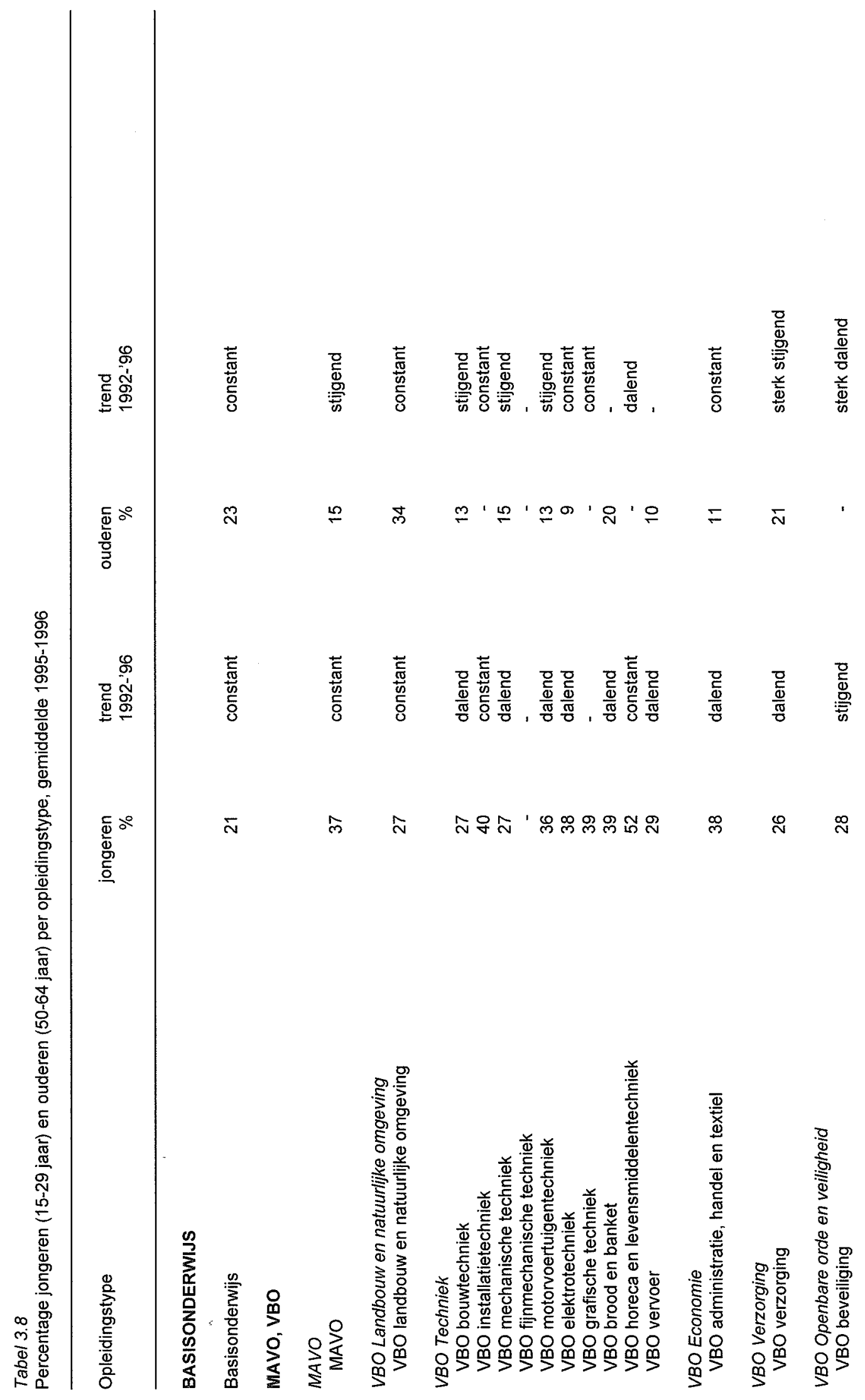




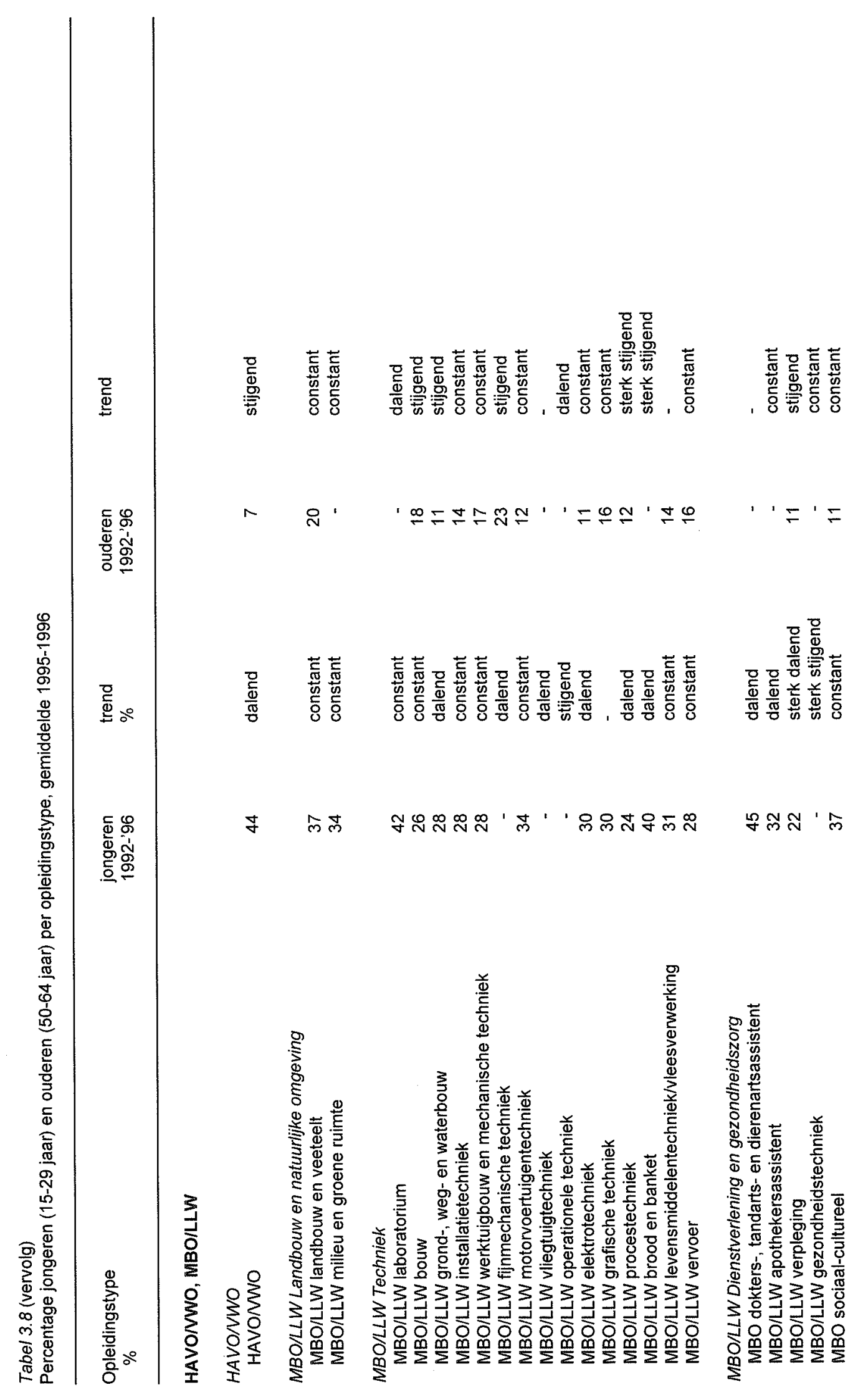




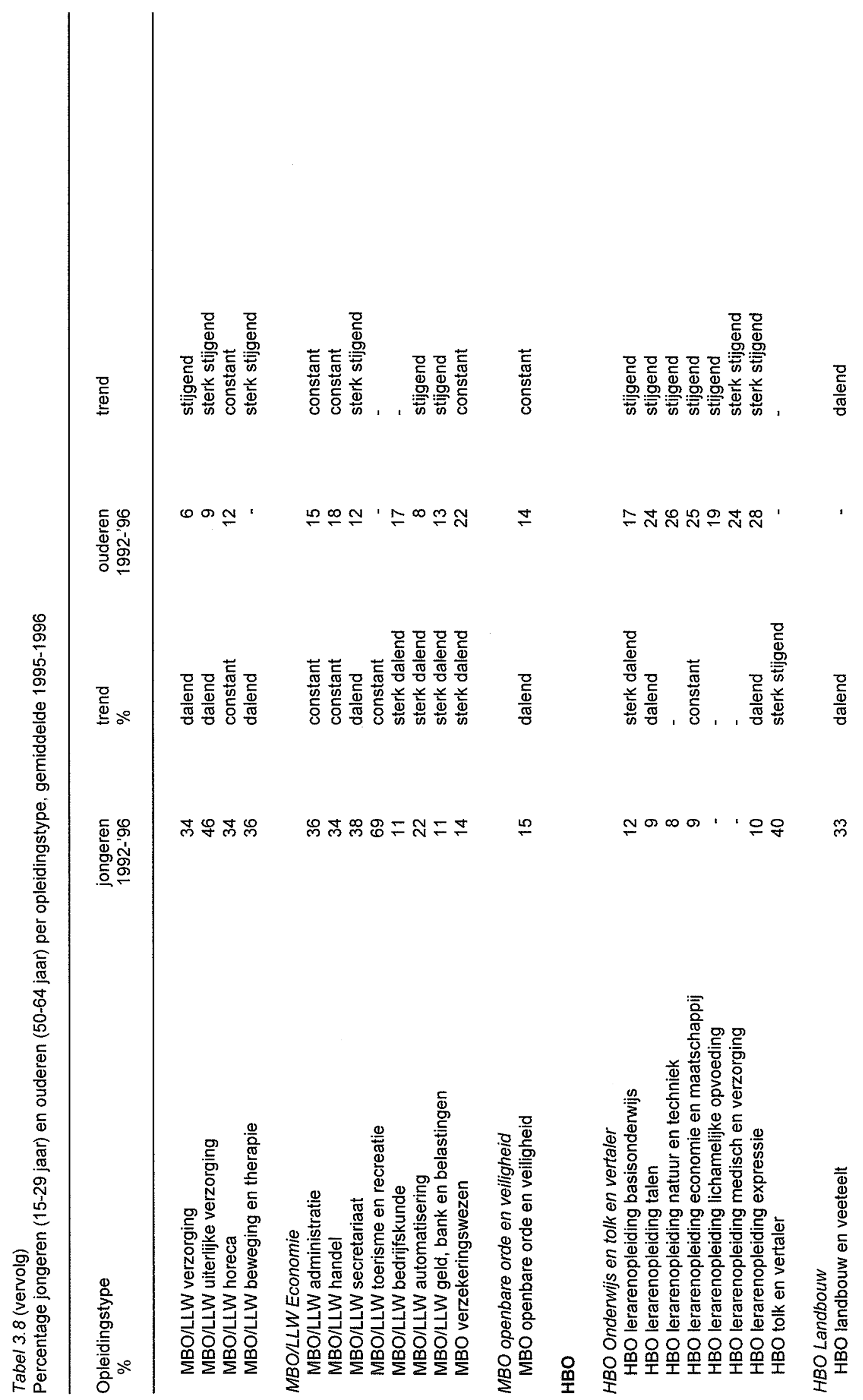




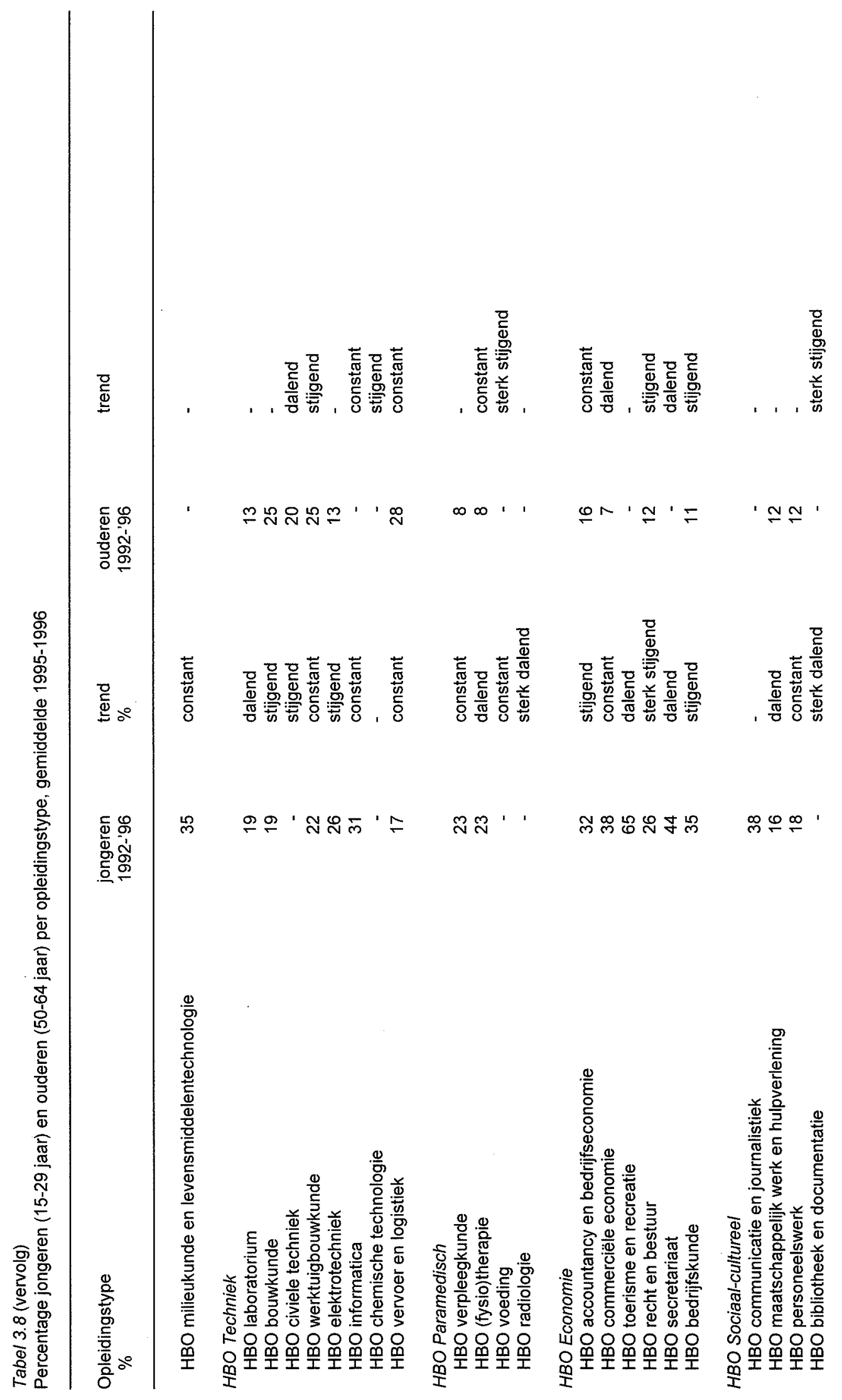




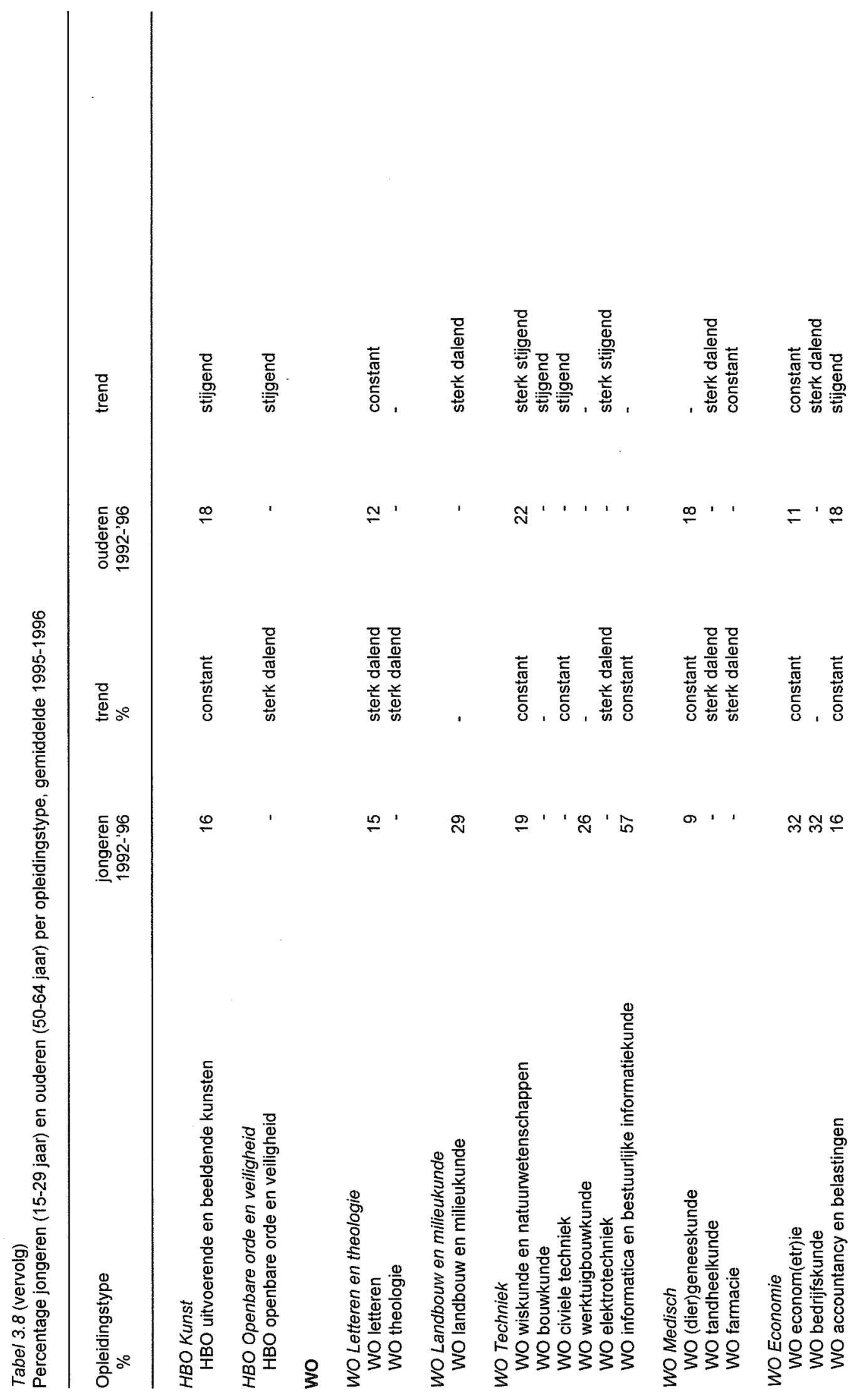




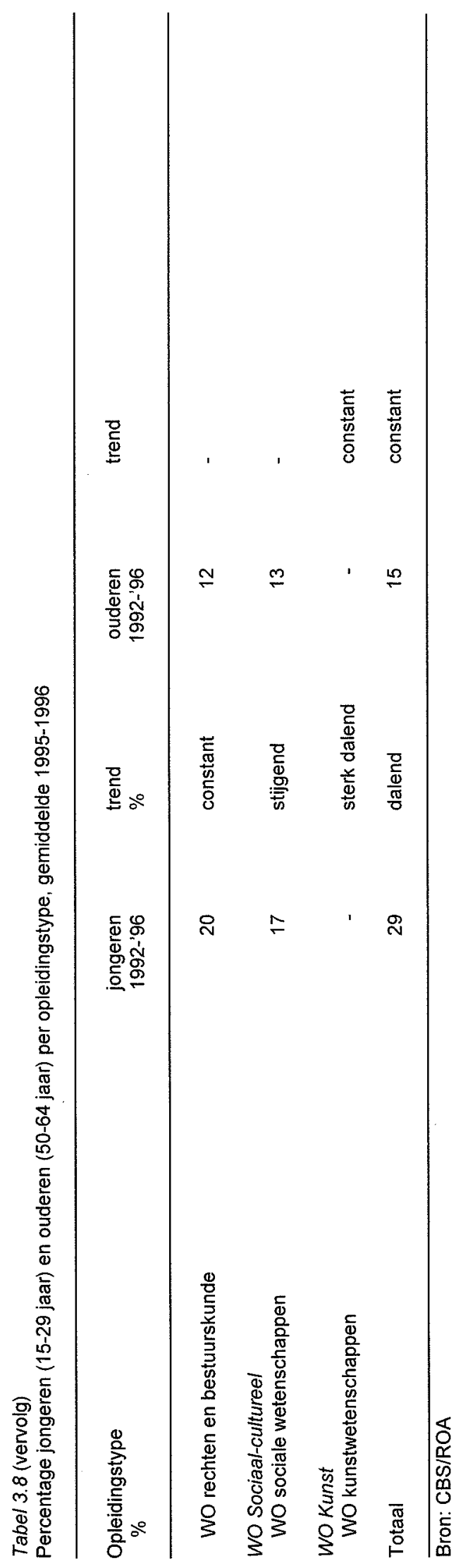


Tabel 3.9

Deeltijdarbeid per opleidingstype, gemiddelde 1995-1996

Opleidingstype

$\%$

trend

1992-'96

gemiddeld aantal

uren per week

\section{BASISONDERWIJS}

Basisonderwijs

MAVO, VBO

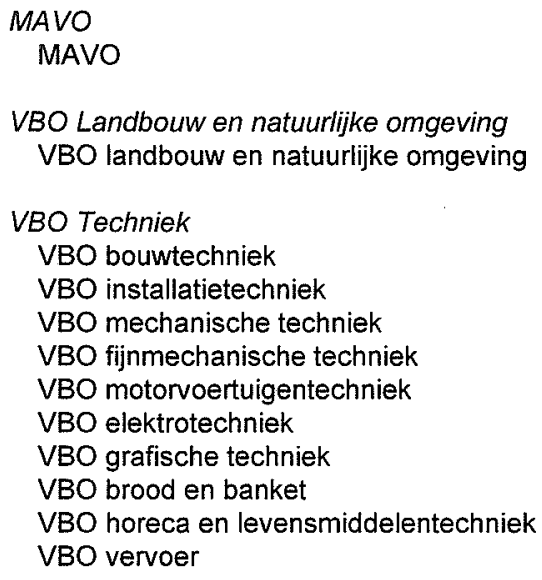

VBO Landbouw en natuurlijke omgeving VBO landbouw en natuurlijke omgeving

- $\quad$ sterk stijgend $\quad 39$

\section{VBO Economie}

VBO administratie, handel en textiel

\section{VBO Verzorging}

VBO verzorging

VBO Openbare orde en veiligheid VBO beveiliging

\section{HAVO/VWO, MBO/LLW}

HAVONWO
HAVONWO

MBO Landbouw en natuurlijke omgeving $\mathrm{MBO} / L L W$ landbouw en veeteelt MBO/LLW milieu en groene ruimte

\section{MBO/LLW Techniek}

MBO/LLW laboratorium

MBO/LLW bouw

MBO/LLW grond-, weg- en waterbouw

$\mathrm{MBO} / L L W$ installatietechniek

MBO/LLW werktuigbouw en mechanische techniek

MBO/LLW fijnmechanische techniek

MBO/LLW motorvoertuigentechniek

$\mathrm{MBO} / \mathrm{LLW}$ vliegtuigtechniek

MBO/LLW operationele techniek

MBO/LLW elektrotechniek

MBO/LLW grafische techniek

MBO/LLW procestechniek 


\begin{tabular}{|c|c|c|c|}
\hline Opleidingstype & $\%$ & $\begin{array}{l}\text { trend } \\
1992-' 96\end{array}$ & $\begin{array}{l}\text { gemiddeld aantal } \\
\text { uren per week }\end{array}$ \\
\hline
\end{tabular}

MBO/LLW brood en banket

MBO/LLW levensmiddelentechniek/vleesverwerking MBO/LLW vervoer

MBO/LLW Dienstverlening en gezondheidszorg MBO dokters-, tandarts- en dierenartsassistent MBO/LLW apothekersassistent

$M B O / L L W$ verpleging

MBO/LLW gezondheidstechniek

MBO sociaal-cultureel

$\mathrm{MBO} / L L W$ verzorging

$\mathrm{MBO} / \mathrm{LLW}$ uiterlijke verzorging

$\mathrm{MBO}$ LLW horeca

$\mathrm{MBO} / \mathrm{LLW}$ beweging en therapie

MBO/LLW Economie

$\mathrm{MBO} / \mathrm{LLW}$ administratie

MBO/LLW handel

MBO/LLW secretariaat

$\mathrm{MBO} / \mathrm{LLW}$ toerisme en recreatie

MBO/LLW bedrijfskunde

MBO/LLW automatisering

$\mathrm{MBO} / \mathrm{LLW}$ geld, bank en belastingen

MBO verzekeringswezen

MBO Openbare orde en veiligheid

MBO openbare orde en veiligheid

\section{HBO}

HBO Onderwijs en tolk en vertaler

HBO lerarenopleiding basisonderwijs

HBO lerarenopleiding talen

HBO lerarenopleiding natuur en techniek

HBO lerarenopleiding economie en maatschappij

HBO lerarenopleiding lichamelijke opvoeding

$\mathrm{HBO}$ lerarenopleiding medisch en verzorging

$\mathrm{HBO}$ lerarenopleiding expressie

$\mathrm{HBO}$ tolk en vertaler

HBO Landbouw

$\mathrm{HBO}$ landbouw en veeteelt

HBO milieukunde en levensmiddelentechnologie

HBO Techniek

$\mathrm{HBO}$ laboratorium

HBO bouwkunde

HBO civiele techniek

HBO werktuigbouwkunde

HBO elektrotechniek

HBO informatica

HBO chemische technologie

HBO vervoer en logistiek

$\begin{array}{lll}- & - & 42 \\ - & \text { sterk stijgend } & 44 \\ 11 & \text { constant } & 42\end{array}$

stijgend

30

4

stijgend

stijgend

constant

stijgend

stijgend

stijgend

stijgend

42

42

stijgend $\quad 37$

stijgend $\quad 40$

stijgend $\quad 31$

stijgend $\quad 36$

sterk stijgend 39

stijgend 38

sterk stijgend 37

stijgend $\quad 40$

sterk stijgend

39

$\begin{array}{ll}\text { stijgend } & 33 \\ \text { constant } & 34 \\ \text { constant } & 38 \\ \text { stijgend } & 36 \\ \text { constant } & 37 \\ \text { constant } & 31 \\ \text { constant } & 33 \\ \text { sterk stijgend } & 30\end{array}$

46

- $\quad$ sterk stijgend 39

30

stijgend $\quad 35$

- $\quad$ sterk stijgend 40

- constant 39

- $\quad$ stijgend 41

- $\quad$ sterk stijgend 40

11 sterk stijgend 39

- $\quad$ sterk stijgend 39

- $\quad$ sterk stijgend 42 
Tabel 3.9 (vervolg)

Deeltijdarbeid per opleidingstype, gemiddelde 1995-1996

\begin{tabular}{lccc}
\hline Opleidingstype & $\%$ & $\begin{array}{c}\text { trend } \\
1992-96\end{array}$ & $\begin{array}{l}\text { gemiddeld aantal } \\
\text { uren per week }\end{array}$ \\
\hline $\begin{array}{l}\text { WO Sociaal-cultureel } \\
\text { WO sociale wetenschappen }\end{array}$ & 37 & constant & 35 \\
$\begin{array}{l}\text { WO Kunst } \\
\text { WO kunstwetenschappen }\end{array}$ & - & - & 38 \\
Totaal & 27 & stijgend & 37 \\
\hline
\end{tabular}

Bron: CBS/ROA

Toelichting:

Deeltijdarbeid betreft personen die minstens 12 uur maar hoogstens 32 uur per week werkzaam zijn. 
Tabel 3.10

Deeltijdarbeid onder werkzame schoolverlaters per opleidingsrichting, 1996

Opleidingstype

$\%$

typering

VBO, MAVO

\section{MAVO}

MAVO

VBO Landbouw en natuurlijke omgeving VBO landbouw en natuurlijke omgeving

VBO Techniek

VBO bouwtechniek

VBO mechanische techniek

VBO motorvoertuigentechniek

VBO elektrotechniek

VBO horeca en levensmiddelentechniek

VBO Economie

VBO administratie, handel en textiel

VBO Verzorging

VBO verzorging

MBO, HAVONWO

\section{HAVONWO \\ HAVONWO}

MBO landbouw en natuurlijke omgeving

KMBO landbouw en veeteelt

KMBO milieu en groene ruimte

$M B O$ landbouw en veeteelt

MBO milieu en groene ruimte

MBO Techniek

KMBO bouw

KMBO grond-, weg- en waterbouw

KMBO werktuigbouw en mechanische techniek

KMBO motorvoertuigentechniek

KMBO elektrotechniek

KMBO brood en banket

MBO bouw

MBO grond-, weg- en waterbouw

$\mathrm{MBO}$ installatietechniek

MBO werktuigbouw en mechanische techniek

MBO motorvoertuigentechniek

MBO elektrotechniek

MBO grafische techniek

MBO procestechniek

MBO levensmiddelentechniek/vleesverwerking

MBO Dienstverlening en gezondheidszorg

$\mathrm{KMBO}$ verzorging

$\mathrm{KMBO}$ horeca

44

45

$-$

73

54

56

54

hoog

64

erg hoog

hoog

erg hoog

hoog

erg hoog

$-$

24

14

44

36

22

$-$

16

$-$

5

2

28

2

22

9

8

13

13

58

55

41

MBO dokters-, tandarts- en dierenartsassistent

MBO apothekersassistent

$M B O$ verpleging

MBO sociaal-cultureel hoog

gemiddeld

gemiddeld

gemiddeld

hoog

gemiddeld

gemiddeld

gemiddeld

laag

erg laag

gemiddeld

erg laag

gemiddeld

gemiddeld

laag

gemiddeld

gemiddeld

erg hoog

hoog

gemiddeld

gemiddeld

hoog

hoog 


$\begin{array}{lll}\text { Opleidingstype } & \% & \text { typering }\end{array}$

\section{$M B O$ verzorging}

MBO uiterlijke verzorging

MBO horeca

MBO beweging en therapie

MBO Economie

KMBO administratie

KMBO handel

MBO administratie

MBO handel

MBO toerisme en recreatie
50

40

11

65

35

62

12

24

16 hoog

gemiddeld

gemiddeld

erg hoog

gemiddeld

erg hoog

gemiddeld

gemiddeld

gemiddeld

\section{HBO}

HBO Onderwijs en tolk en vertaler

HBO lerarenopleiding basisonderwijs 33

HBO lerarenopleiding talen 43

HBO lerarenopleiding natuur en techniek 27

HBO lerarenopleiding expressie $\quad 68$

HBO tolk en vertaler $\quad 17$

gemiddeld

hoog

gemiddeld

erg hoog

gemiddeld

HBO Landbouw

$\mathrm{HBO}$ landbouw en veeteelt 5

laag

HBO milieukunde en levensmiddelentechnologie $\quad 10$

gemiddeld

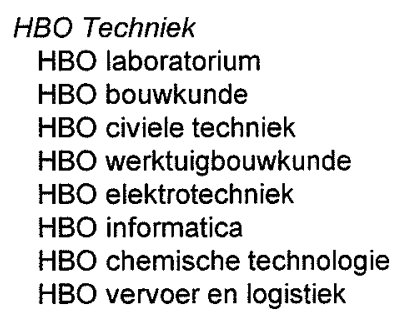

5

3

5

1

2

2

6

3

HBO Paramedisch
HBO verpleegkunde
HBO (fysio)therapie
HBO voeding
HBO radiologie

HBO Economie

HBO accountancy en bedrijfseconomie

HBO commerciële economie

$\mathrm{HBO}$ toerisme en recreatie

HBO recht en bestuur

HBO secretariaat

$\mathrm{HBO}$ bedrijfskunde

HBO Sociaal-cultureel

HBO communicatie en journalistiek

HBO maatschappelijk werk en hulpverlening

HBO personeelswerk

HBO bibliotheek en documentatie

HBO sociaal-cultureel overig
43

55

31

17

6

3

18

8 .

2

5 laag

erg laag

laag

erg laag

erg laag

erg laag

laag

erg laag

hoog

hoog

gemiddeld

gemiddeld

laag

erg laag

gemiddeld

laag

erg laag

laag

gemiddeld

erg hoog

gemiddeld

gemiddeld

gemiddeld 
Tabel 3.10 (vervolg)

Deeltijdarbeid onder werkzame schoolverlaters per opleidingsrichting, 1996

Opleidingstype

HBO Kunst

$\mathrm{HBO}$ uitvoerende en beeldende kunsten

wo

WO Economie

WO econom(etr)ie

WO bedrijfskunde

WO accountancy en belastingen
$\%$

typering

54

hoog

Bron: ROA (schoolverlatersenquêtes RUBS, HBO-Monitor, WO-economie scanner)

\section{Toelichting:}

Deeltijdarbeid betreft de schoolverlaters die hoogstens 32 uur maar minstens 12 uur per week werkzaam zijn. 
Tabel 3.11

Flexibel en vast werk per opleidingstype, gemiddelde 1995-1996

\begin{tabular}{lrrrr}
\hline & & & \\
Opleidingstype & Flexibel & trend & Vast & trend \\
& werk & $1992-96$ & werk & $1992-96$ \\
& $\%$ & & $\%$ & \\
\hline
\end{tabular}

\section{BASISONDERWIJS}

Basisonderwijs

MAVO, VBO
13

VBO landbouw en natuurlijke omgeving

\section{VBO Techniek}

VBO bouwtechniek

VBO installatietechniek

VBO mechanische techniek

VBO fijnmechanische techniek

VBO motorvoertuigentechniek

VBO elektrotechniek

VBO grafische techniek

VBO brood en banket

VBO horeca en levensmiddelentechniek

VBO vervoer

VBO Economie

VBO administratie, handel en textiel

VBO Verzorging

VBO verzorging

VBO Openbare orde en veiligheid

$\mathrm{VBO}$ beveiliging

HAVONWO, MBO/LLW
11

stijgend

88

constant
5

86

constant

90

constant

stijgend

sterk stijgend

sterk stijgend

sterk stijgend

-

$-$

sterk stijgend

sterk stijgend

stijgend

dalend

13

sterk stijgend

14

stijgend

sterk stijgend

constant

\section{HAVONWO \\ HAVONWO}

MBO/LLW landbouw en natuurlijke omgeving MBO/LLW landbouw en veeteelt MBO/LLW milieu en groene ruimte
16

constant

constant

sterk stijgend

constant

constant

sterk stijgend sterk stijgend sterk dalend sterk stijgend

MBO/LLW fijnmechanische techniek

$\mathrm{MBO} / \mathrm{LLW}$ motorvoertuigentechniek

$\mathrm{MBO} / \mathrm{LLW}$ vliegtuigtechniek

MBO/LLW operationele techniek

MBO/LLW elektrotechniek sterk stijgend

sterk stijgend

94 constant constant constant constant

constant constant constant constant constant constant
86

constant

83

constant

92

constant

82

constant

92

93

constant

constant

constant

constant

constant

constant

constant 


\begin{tabular}{|c|c|c|c|c|}
\hline Opleidingstype & $\begin{array}{r}\text { Flexibel } \\
\text { werk } \\
\%\end{array}$ & $\begin{array}{l}\text { trend } \\
1992-96\end{array}$ & $\begin{array}{r}\text { Vast } \\
\text { werk } \\
\%\end{array}$ & $\begin{array}{l}\text { trend } \\
1992-^{\prime} 96\end{array}$ \\
\hline MBO/LLW grafische techniek & - & sterk stijgend & 96 & constant \\
\hline MBO/LLW procestechniek & - & - & 98 & constant \\
\hline MBO/LLW brood en banket & - & sterk stijgend & 96 & constant \\
\hline MBO/LLW levensmiddelentechniek/ & & & & \\
\hline vleesverwerking & - & stijgend & 94 & constant \\
\hline MBO/LLW vervoer & 7 & sterk stijgend & 92 & constant \\
\hline \multicolumn{5}{|c|}{ MBO/LLW Dienstverlening en gezondheidszorg } \\
\hline MBO dokters-, tandarts- en dierenarts & sistent - & - & 93 & constant \\
\hline MBO/LLW apothekersassistent & - & - & 97 & constant \\
\hline MBO/LLW verpleging & 10 & constant & 89 & constant \\
\hline MBO/LLW gezondheidstechniek & - & - & 89 & stijgend \\
\hline MBO sociaal-cultureel & 11 & stijgend & 88 & constant \\
\hline MBO/LLW verzorging & 12 & stijgend & 88 & constant \\
\hline MBO/LLW uiterlijke verzorging & 8 & constant & 88 & constant \\
\hline MBO/LLW horeca & 8 & sterk stijgend & 90 & constant \\
\hline MBO/LLW beweging en therapie & 12 & sterk stijgend & 86 & dalend \\
\hline \multicolumn{5}{|l|}{ MBO/LLWEconomie } \\
\hline MBO/LLW administratie & 8 & sterk stijgend & 92 & constant \\
\hline MBO/LLW handel & 6 & constant & 92 & constant \\
\hline MBO/LLW secretariaat & 11 & stijgend & 88 & constant \\
\hline MBO/LLW toerisme en recreatie & - & sterk stijgend & 87 & constant \\
\hline MBO/LLW bedrijfskunde & - & constant & 98 & constant \\
\hline MBO/LLW automatisering & - & - & 94 & constant \\
\hline MBO/LLW geld, bank en belastingen & - & sterk stijgend & 100 & constant \\
\hline MBO verzekeringswezen & - & - & 95 & constant \\
\hline \multicolumn{5}{|l|}{ MBO openbare orde en veiligheid } \\
\hline MBO openbare orde en veiligheid & 3 & sterk stijgend & 97 & constant \\
\hline
\end{tabular}

HBO

HBO Onderwijs en tolk en vertaler HBO lerarenopleiding basisonderwijs $\mathrm{HBO}$ lerarenopleiding talen HBO lerarenopleiding natuur en techniek $\mathrm{HBO}$ lerarenopleiding economie en maatschappi] HBO lerarenopleiding lichamelijke opvoeding $\mathrm{HBO}$ lerarenopleiding medisch en verzorging $\mathrm{HBO}$ lerarenopleiding expressie $\mathrm{HBO}$ tolk en vertaler

\begin{tabular}{|c|c|c|c|}
\hline 8 & dalend & 92 & constant \\
\hline 8 & - & 92 & constant \\
\hline - & sterk stijgend & 96 & constant \\
\hline - & constant & 97 & constant \\
\hline . & - & 96 & constant \\
\hline - & - & 96 & constant \\
\hline - & dalend & 94 & constant \\
\hline - & sterk stijgend & 69 & dalend \\
\hline - & sterk stijgend & 90 & dalend \\
\hline - & sterk stijgend & 93 & constant \\
\hline 7 & sterk stijgend & 93 & constant \\
\hline- & sterk stijgend & 91 & constant \\
\hline & - & 97 & constant \\
\hline & stijgend & 94 & constant \\
\hline
\end{tabular}

$\begin{array}{lllll}\text { HBO Landbouw } & & & & \\ \text { HBO landbouw en veeteelt } & - & \text { sterk stijgend } & 90 & \text { dalend } \\ \text { HBO milieukunde en levensmiddelen- } & - & \text { sterk stijgend } & 93 & \text { constant } \\ \text { technologie } & - & & & \\ \text { HBO Techniek } & 7 & \text { sterk stijgend } & 93 & \text { constant } \\ \quad \text { HBO laboratorium } & - & \text { sterk stijgend } & 91 & \text { constant } \\ \text { HBO bouwkunde } & - & - & 97 & \text { constant } \\ \text { HBO civiele techniek } & - & \text { stijgend } & 94 & \text { constant } \\ \text { HBO werktuigbouwkunde } & & & \end{array}$


Tabel 3.11 (vervolg)

Flexibel en vast werk per opleidingstype, gemiddelde 1995-1996

\begin{tabular}{lrrrr}
\hline & & & \\
Opleidingstype & Flexibel & trend & Vast & trend \\
& werk & $1992-' 96$ & werk & $1992-' 96$ \\
$\%$ & & & $\%$
\end{tabular}

HBO elektrotechniek

HBO chemische technologie

HBO vervoer en logistiek

\author{
HBO Paramedisch \\ $\mathrm{HBO}$ verpleegkunde \\ HBO (fysio)therapie \\ $\mathrm{HBO}$ voeding \\ $\mathrm{HBO}$ radiologie
}

\section{HBO Economie}

HBO accountancy en bedrijfseconomie

HBO commerciële economie

$\mathrm{HBO}$ toerisme en recreatie

HBO recht en bestuur

HBO secretariaat

HBO bedrijfskunde

HBO Sociaal-cultureel

HBO communicatie en journalistiek

HBO maatschappelijk werk en hulpverlening

HBO personeelswerk

HBO bibliotheek en documentatie

HBO Kunst

HBO uitvoerende en beeldende kunsten

8

HBO Openbare orde en veiligheid

HBO openbare orde en veiligheid

7
HBO informatica

$7 \quad-$

- 93

sterk stijgend 96

sterk stijgend $\quad 100$

- $\quad$ sterk stijgend

92

constant

constant

constant

constant

stijgend

dalend

sterk dalend

93

81

100

100

constant

stijgend

constant

-

constant

6 sterk stijgend

93

constant

sterk stijgend

sterk stijgend

-

sterk stijgend

constant

96 constant

88 constant

91 dalend

92 constant

93 constant

sterk stijgend

sterk stijgend

sterk stijgend

constant

constant

88

91

92

92

constant

constant

constant

86

constant

constant

sterk stijgend

constant

wo

WO Letteren en theologie
WO letteren
WO theologie

stijgend

91

100

constant

constant

WO Landbouw en milieukunde

WO landbouw en milieukunde

constant

96

constant

WO Techniek

WO wiskunde en natuurwetenschappen

WO bouwkunde

WO civiele techniek

WO werktuigbouwkunde

WO elektrotechniek

WO informatica en bestuurlijke informatiekunde-

sterk stijgend

96

92

constant

92

-

$-$

94

100

92

constant

constant

constant

constant

constant

constant

\footnotetext{
WO Medisch

WO (dier)geneeskunde

WO tandheelkunde

WO farmacie
}

$\begin{array}{lr}\text { constant } & 93 \\ - & 100 \\ \text { sterk stijgend } & 100\end{array}$

constant

constant

constant 
Tabel 3.11 (vervolg)

Flexibel en vast werk per opleidingstype, gemiddelde 1995-1996

\begin{tabular}{|c|c|c|c|c|}
\hline Opleidingstype & $\begin{array}{r}\text { Flexibel } \\
\text { werk } \\
\%\end{array}$ & $\begin{array}{l}\text { trend } \\
1992-' 96\end{array}$ & $\begin{array}{r}\text { Vast } \\
\text { werk } \\
\%\end{array}$ & $\begin{array}{l}\text { trend } \\
1992-' 96\end{array}$ \\
\hline \multicolumn{5}{|l|}{ WO Economie } \\
\hline WO econom(etr)ie & 6 & sterk stijgend & 93 & constant \\
\hline WO bedrijfskunde & - & - & 94 & constant \\
\hline WO accountancy en belastingen & - & sterk stijgend & 96 & constant \\
\hline WO rechten en bestuurskunde & 5 & sterk stijgend & 95 & constant \\
\hline \multicolumn{5}{|l|}{ WO Sociaal-cultureel } \\
\hline WO sociale wetenschappen & 9 & sterk stijgend & 90 & constant \\
\hline \multicolumn{5}{|l|}{ WO Kunst } \\
\hline WO kunstwetenschappen & - & - & 89 & constant \\
\hline Totaal & 8 & stijgend & 91 & constant \\
\hline
\end{tabular}

Bron: CBS/ROA

\section{Toelichting:}

Van een flexibele arbeidsrelatie is sprake indien er geen vast dienstverband is overeengekomen bij uitzendkrachten, oproepkrachten, invalskrachten en contracten zonder een vast aantal arbeidsuren. Een arbeidscontract wordt als niet-vast beschouwd als de contractuele termijn korter is dan een jaar en er geen vooruitzicht is op een vast dienstverband. 
Tabel 3.12

Percentage werkzame schoolverlaters met een vast dienstverband per opleidingsrichting, 1996

$\begin{array}{lll}\text { Opleidingstype } & \% & \text { typering }\end{array}$

VBO, MAVO

MAVO

MAVO

69

hoog

VBO Landbouw en natuurlijke omgeving

VBO landbouw en natuurlijke omgeving

57

gemiddeld

VBO Techniek

VBO bouwtechniek

VBO mechanische techniek

VBO motorvoertuigentechniek

VBO elektrotechniek

VBO horeca en levensmiddelentechniek

53

laag

-

26

erg laag

VBO Economie

VBO administratie, handel en textiel

64

hoog

VBO Verzorging

VBO verzorging

50

laag

MBO, HAVONWV

\section{HAVONWO}

HAVO/WWO

56

MBO landbouw en natuurlijke omgeving

KMBO landbouw en veeteelt

KMBO milieu en groene ruimte

$M B O$ landbouw en veeteelt

MBO milieu en groene ruimte

MBO Techniek

KMBO bouw

KMBO grond-, weg- en waterbouw

KMBO werktuigbouw en mechanische techniek

KMBO motorvoertuigentechniek

KMBO elektrotechniek

KMBO brood en banket

MBO bouw

MBO grond-, weg- en waterbouw

MBO installatietechniek

MBO werktuigbouw en mechanische techniek

MBO motorvoertuigentechniek

MBO elektrotechniek

MBO grafische techniek

MBO procestechniek

MBO levensmiddelentechniek/vleesverwerking

MBO Dienstverlening en gezondheidszorg

$\mathrm{KMBO}$ verzorging

KMBO horeca

MBO dokters-, tandarts- en dierenartsassistent

MBO apothekersassistent

$M B O$ verpleging

MBO sociaal-cultureel 
Tabel 3.12 (vervolg)

Percentage werkzame schoolverlaters met een vast dienstverband per opleidingsrichting, 1996

\begin{tabular}{|c|c|c|}
\hline Opleidingstype & $\%$ & typering \\
\hline MBO verzorging & 45 & laag \\
\hline MBO uiterlijke verzorging & 59 & gemiddeld \\
\hline MBO horeca & 68 & hoog \\
\hline MBO beweging en therapie & 65 & hoog \\
\hline \multicolumn{3}{|l|}{ MBO Economie } \\
\hline KMBO administratie & 47 & laag \\
\hline KMBO handel & 50 & laag \\
\hline MBO administratie & 54 & gemiddeld \\
\hline MBO handel & 67 & hoog \\
\hline MBO toerisme en recreatie & 62 & gemiddeld \\
\hline \multicolumn{3}{|l|}{ HBO } \\
\hline \multicolumn{3}{|l|}{ HBO Onderwijs en tolk en vertaler } \\
\hline HBO lerarenopleiding basisonderwijs & 54 & gemiddeld \\
\hline HBO lerarenopleiding talen & 43 & erg laag \\
\hline HBO lerarenopleiding natuur en techniek & 55 & gemiddeld \\
\hline HBO lerarenopleiding expressie & 50 & laag \\
\hline HBO tolk en vertaler & 58 & gemiddeld \\
\hline \multicolumn{3}{|l|}{ HBO Landbouw } \\
\hline HBO landbouw en veeteelt & 53 & laag \\
\hline HBO milieukunde en levensmiddelentechnologie & 39 & erg laag \\
\hline \multicolumn{3}{|l|}{ HBO Techniek } \\
\hline HBO laboratorium & 40 & erg laag \\
\hline HBO bouwkunde & 74 & erg hoog \\
\hline HBO civiele techniek & 57 & gemiddeld \\
\hline HBO werktuigbouwkunde & 54 & gemiddeld \\
\hline HBO elektrotechniek & 60 & gemiddeld \\
\hline HBO informatica & 74 & erg hoog \\
\hline HBO chemische technologie & 52 & laag \\
\hline $\mathrm{HBO}$ vervoer en logistiek & 73 & hoog \\
\hline \multicolumn{3}{|l|}{ HBO Paramedisch } \\
\hline HBO verpleegkunde & 71 & hoog \\
\hline HBO (fysio)therapie & 66 & hoog \\
\hline HBO voeding & 58 & gemiddeld \\
\hline HBO radiologie & 74 & erg hoog \\
\hline \multicolumn{3}{|l|}{ HBO Economie } \\
\hline HBO accountancy en bedrijfseconomie & 63 & hoog \\
\hline HBO commerciële economie & 63 & hoog \\
\hline HBO toerisme en recreatie & 49 & laag \\
\hline HBO recht en bestuur & 35 & erg laag \\
\hline HBO secretariaat & 52 & laag \\
\hline HBO bedrijfskunde & 58 & gemiddeld \\
\hline \multicolumn{3}{|l|}{ HBO Sociaal-cultureel } \\
\hline HBO communicatie en journalistiek & 45 & laag \\
\hline HBO maatschappelijk werk en hulpveriening & 57 & gemiddeld \\
\hline HBO personeelswerk & 41 & erg laag \\
\hline HBO bibliotheek en documentatie & 44 & laag \\
\hline HBO sociaal-cultureel overig & 54 & gemiddeld \\
\hline
\end{tabular}


Tabel 3.12 (vervolg)

Percentage werkzame schoolverlaters met een vast dienstverband per opleidingsrichting, 1996

Opleidingstype

HBO Kunst

$\mathrm{HBO}$ uitvoerende en beeldende kunsten

WO

WO Economie

WO econom(etr)ie

WO bedrijfskunde

WO accountancy en belastingen
$\%$

54

62

63

78 gemiddeld

typering

gemiddeld

hoog

erg hoog

Bron: ROA (schoolverlatersenquêtes RUBS, HBO-Monitor, WO-economie scanner) 
Tabel 3.13

Zelfstandigen per opleidingstype, gemiddelde 1995-1996

Opleidingstype

$\%$

typering trend

1992-'96

\section{BASISONDERWIJS}

Basisonderwijs

10

gemiddeld

stijgend

MAVO, VBO

MAVO
MAVO

9

VBO Landbouw en natuurlijke omgeving

VBO landbouw en natuurlijke omgeving

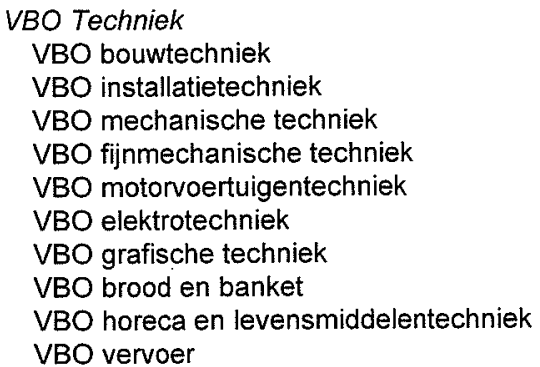

\section{VBO Economie}

VBO administratie, handel en textiel

\section{VBO Verzorging \\ VBO verzorging}

VBO Openbare orde en veiligheid

VBO beveiliging

HAVO/NWO, MBO/LLW

8

16
9

51

14

$\mathrm{MBO} / \mathrm{LLW}$ milieu en groene ruimte

MBO/LLW Techniek

$\mathrm{MBO} / \mathrm{LLW}$ laboratorium

MBO/LLW bouw

$\mathrm{MBO} / \mathrm{LLW}$ grond-, weg- en waterbouw

MBO/LLW installatietechniek

MBO/LLW werktuigbouw en mechanische techniek

MBO/LLW fijnmechanische techniek

MBO/LLW motorvoertuigentechniek

MBO/LLW vliegtuigtechniek

MBO/LLW operationele techniek

MBO/LLW elektrotechniek

MBO/LLW grafische techniek

MBO/LLW procestechniek gemiddeld stijgend

erg hoog

constant

gemiddeld

laag

gemiddeld

gemiddeld

gemiddeld

laag

gemiddeld

gemiddeld

gemiddeld

gemiddeld

gemiddeld

constant

hoog

stijgend

erg laag

sterk dalend

constant

stijgend

sterk stijgend

constant

sterk stijgend

sterk stijgend

gemiddeld stijgend

erg hoog constant

hoog

erg laag

hoog

gemiddeld

hoog

gemiddeld

gemiddeld

hoog

erg laag

gemiddeld

laag

hoog

erg laag sterk stijgend

constant

-

constant

stijgend

constant

-

sterk stijgend

constant

stijgend 
MBO/LLW brood en banket

MBO/LLW levensmiddelentechniek/vleesverwerking MBO/LLW vervoer

MBO/LLW Dienstverlening en gezondheidszorg MBO dokters-, tandarts- en dierenartsassistent MBO/LLW apothekersassistent $M B O / L L W$ verpleging MBO/LLW gezondheidstechniek MBO sociaal-cultureel $M B O / L L W$ verzorging MBO/LLW uiterlijke verzorging MBO/LLW horeca MBO/LLW beweging en therapie

MBO/LLW Economie MBO/LLW administratie MBO/LLW handel MBO/LLW secretariaat MBO/LLW toerisme en recreatie MBO/LLW bedrijfskunde MBO/LLW automatisering MBO/LLW geld, bank en belastingen $M B O$ verzekeringswezen

$M B O$ Openbare orde en veiligheid MBO openbare orde en veiligheid

\section{HBO}

$H B O$ Onderwijs en tolk en vertaler HBO lerarenopleiding basisonderwijs HBO lerarenopleiding talen $\mathrm{HBO}$ lerarenopleiding natuur en techniek $\mathrm{HBO}$ lerarenopleiding economie en maatschappij HBO lerarenopleiding lichamelijke opvoeding HBO lerarenopleiding medisch en verzorging $\mathrm{HBO}$ lerarenopleiding expressie $\mathrm{HBO}$ tolk en vertaler

\section{HBO Landbouw}

$\mathrm{HBO}$ landbouw en veeteelt

HBO milieukunde en levensmiddelentechnologie

\author{
HBO Techniek \\ $\mathrm{HBO}$ laboratorium \\ HBO bouwkunde \\ HBO civiele techniek \\ $\mathrm{HBO}$ werktuigbouwkunde \\ HBO elektrotechniek \\ HBO informatica \\ HBO chemische technologie \\ HBO vervoer en logistiek
}

hoog

hoog

hoog

constant constant dalend

- laag

5 laag

- hoog

- $\quad$ erg laag

constant

dalend sterk dalend

dalend

stijgend

constant constant sterk stijgend

gemiddeld

stijgend constant sterk stijgend constant sterk stijgend sterk stijgend constant

sterk stijgend

sterk dalend

- laag
gemiddeld laag gemiddeld gemiddeld gemiddeld

constant 
Tabel 3.13 (vervolg)

Zelfstandigen per opleidingstype, gemiddelde 1995-1996

$\begin{array}{lcc}\text { Opleidingstype } & \% & \begin{array}{c}\text { typering } \\ 1992-96\end{array}\end{array}$ trend

HBO verpleegkunde

HBO (fysio)therapie

$\mathrm{HBO}$ voeding

$\mathrm{HBO}$ radiologie

HBO Economie

$\mathrm{HBO}$ accountancy en bedrijfseconomie

HBO commerciële economie

$\mathrm{HBO}$ toerisme en recreatie

$\mathrm{HBO}$ recht en bestuur

HBO secretariaat

$\mathrm{HBO}$ bedrijfskunde

HBO Sociaal-cultureel

$\mathrm{HBO}$ communicatie en journalistiek

HBO maatschappelijk werk en hulpverlening

HBO personeelswerk

HBO bibliotheek en documentatie

\section{HBO Kunst}

$\mathrm{HBO}$ uitvoerende en beeldende kunsten

HBO Openbare orde en veiligheid

$\mathrm{HBO}$ openbare orde en veiligheid

\section{Wo}

WO Letteren en theologie
WO letteren
WO theologie

WO Landbouw en milieukunde

WO landbouw en milieukunde

\author{
WO Techniek \\ WO wiskunde en natuurwetenschappen \\ WO bouwkunde \\ WO civiele techniek \\ WO werktuigbouwkunde \\ WO elektrotechniek \\ WO informatica en bestuurlijke informatiekunde
}

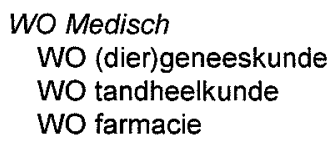

\section{WO Economie}

WO econom(etr)ie

WO bedrijfskunde

WO accountancy en belastingen

WO rechten en bestuurskunde

WO Sociaal-cultureel

WO sociale wetenschappen

$\begin{array}{rll}- & \text { erg laag } & - \\ 33 & \text { erg hoog } & \text { dalend } \\ - & \text { laag } & \text { sterk dalend } \\ - & \text { laag } & \text { sterk stijgend }\end{array}$

$\begin{array}{rll}11 & \text { gemiddeld } & \text { stijgend } \\ 11 & \text { gemiddeld } & - \\ - & \text { erg laag } & \text { constant } \\ - & \text { gemiddeld } & \text { sterk stijgend } \\ - & \text { laag } & \text { stijgend } \\ 7 & \text { gemiddeld } & \text { constant }\end{array}$

$\begin{array}{cll}\text { - } & \text { gemiddeld } & \text { constant } \\ \text { 6 } & \text { laag } & \text { constant } \\ \text { - } & \text { erg laag } & \text { sterk dalend } \\ \text { - } & \text { laag } & \text { sterk stijgend }\end{array}$

43 erg hoog stijgend

erg laag sterk stijgend

\begin{tabular}{|c|c|c|}
\hline $\begin{array}{r}11 \\
-\end{array}$ & $\begin{array}{l}\text { gemiddeld } \\
\text { hoog }\end{array}$ & $\begin{array}{l}\text { sterk stijgend } \\
\text { stijgend }\end{array}$ \\
\hline - & gemiddeld & - \\
\hline 5 & laag & sterk stijgend \\
\hline 31 & erg hoog & constant \\
\hline- & gemiddeld & - \\
\hline - & gemiddeld & sterk stijg \\
\hline - & laag & constant \\
\hline - & gemiddeld & sterk stijgen \\
\hline
\end{tabular}

$\begin{array}{rll}30 & \text { erg hoog } & \text { dalend } \\ 86 & \text { erg hoog } & \text { constant } \\ \text { dalend }\end{array}$

9 gemiddeld constant

- gemiddeld constant

19 hoog dalend

17 hoog stijgend

10 gemiddeld stijgend 
Tabel 3.13 (vervolg)

Zelfstandigen per opleidingstype, gemiddelde 1995-1996

\begin{tabular}{lccc} 
Opleidingstype & $\%$ & $\begin{array}{c}\text { typering } \\
1992-96\end{array}$ & trend \\
\hline $\begin{array}{l}\text { WO Kunst } \\
\text { WO kunstwetenschappen }\end{array}$ & - & hoog & - \\
Totaal & 12 & gemiddeld constant
\end{tabular}

Bron: CBS/ROA

Toelichting:

Het begrip zelfstandig bevat ook personen die werkzaam zijn in het bedrijf of de praktijk van hun partner of ouders en freelancers e.d. 
Tabel 3.14

Gemiddeld bruto maandloon van werkzame schoolverlaters per opleidingsrichting, 1996

\begin{tabular}{cc}
\hline Opleidingstype & $\begin{array}{c}\text { gemiddeld bruto } \\
\text { maandloon, } \\
\text { guldens }\end{array}$ \\
\hline
\end{tabular}

\section{VBO, MAVO}

MAVO
MAVO

VBO Landbouw en natuurlijke omgeving

VBO landbouw en natuurlijke omgeving

VBO Techniek

VBO bouwtechniek

VBO mechanische techniek

VBO motorvoertuigentechniek

VBO elektrotechniek

VBO horeca en levensmiddelentechniek

VBO Economie

VBO administratie, handel en textiel

VBO Verzorging

VBO verzorging

\section{MBO, HAVO/VWO}

HAVONWO

HAVONWO

MBO landbouw en natuurlijke omgeving

$\mathrm{KMBO}$ landbouw en veeteelt

KMBO milieu en groene ruimte

$M B O$ landbouw en veeteelt

MBO milieu en groene ruimte

\section{MBO Techniek}

KMBO bouw

KMBO grond-, weg- en waterbouw

KMBO werktuigbouw en mechanische techniek

KMBO motorvoertuigentechniek

KMBO elektrotechniek

KMBO brood en banket

MBO bouw

MBO grond-, weg- en waterbouw

MBO installatietechniek

MBO werktuigbouw en mechanische techniek

MBO motorvoertuigentechniek

MBO elektrotechniek

MBO grafische techniek

MBO procestechniek

MBO levensmiddelentechniek/vleesverwerking

MBO Dienstverlening en gezondheidszorg

KMBO verzorging

KMBO horeca

MBO dokters-, tandarts- en dierenartsassistent MBO apothekersassistent

$M B O$ verpleging
1.384

1.354

1.583

1.406

1.970

1.802

2.765

2.599

1.875

2.455

2.088

2.399

2.462

2.706

2.555

1.538

1.940

2.349

2.411

2.210 gemiddeld voor mavo/vbo

gemiddeld voor mavo/vbo

hoog voor mavo/vbo

-

gemiddeld voor mavo/vbo

gemiddeld voor mavo/vbo

laag voor mavo/vbo

laag voor havo/vwo/mbo

laag voor havo/vwo/mbo

gemiddeld voor havo/vwo/mbo gemiddeld voor havo/vwo/mbo

gemiddeld voor havo/vwo/mbo gemiddeld voor havo/vwo/mbo laag voor havo/vwo/mbo

laag voor havo/vwo/mbo

hoog voor havo/vwo/mbo hoog voor havo/vwo/mbo laag voor havo/vwo/mbo gemiddeld voor havo/vwo/mbo gemiddeld voor havo/vwo/mbo gemiddeld voor havo/vwo/mbo gemiddeld voor havo/vwo/mbo hoog voor havo/vwo/mbo hoog voor havo/vwo/mbo

laag voor havo/vwo/mbo laag voor havo/vwo/mbo gemiddeld voor havo/vwo/mbo gemiddeld voor havo/vwo/mbo gemiddeld voor havo/vwo/mbo 
Tabel 3.14 (vervolg)

Gemiddeld bruto maandloon van werkzame schoolverlaters per opleidingsrichting, 1996

\begin{tabular}{ccc}
\hline Opleidingstype & $\begin{array}{c}\text { gemiddeld bruto } \\
\text { maandloon, } \\
\text { guldens }\end{array}$ & typering \\
&
\end{tabular}

$\begin{array}{ll}\text { MBO sociaal-cultureel } & 2.243 \\ \text { MBO verzorging } & 2.434 \\ \text { MBO uiterlijke verzorging } & 1.969 \\ \text { MBO horeca } & 2.806 \\ \text { MBO beweging en therapie } & 2.686\end{array}$

$\begin{array}{ll}\text { MBO Economie } & \\ \text { KMBO administratie } & 1.974 \\ \text { KMBO handel } & 1.744 \\ \text { MBO administratie } & 2.180 \\ \text { MBO handel } & 2.093 \\ \text { MBO toerisme en recreatie } & 2.367\end{array}$

HBO

HBO Onderwijs en tolk en vertaler

HBO lerarenopleiding basisonderwijs $\quad 3.297$

HBO lerarenopleiding talen $\quad 3.240$

HBO lerarenopleiding natuur en techniek $\quad 3.321$

HBO lerarenopleiding expressie $\quad 3.082$

$\mathrm{HBO}$ tolk en vertaler $\quad 2.873$

\section{HBO Landbouw}

HBO landbouw en veeteelt $\quad 2.922$

HBO milieukunde en levensmiddelentechnologie $\quad 3.195$

$\begin{array}{ll}\text { HBO Techniek } & \\ \text { HBO laboratorium } & 3.202 \\ \text { HBO bouwkunde } & 3.256 \\ \text { HBO civiele techniek } & 3.353 \\ \text { HBO werktuigbouwkunde } & 3.461 \\ \text { HBO elektrotechniek } & 3.378 \\ \text { HBO informatica } & 3.463 \\ \text { HBO chemische technologie } & 3.290 \\ \text { HBO vervoer en logistiek } & 3.067\end{array}$

HBO Paramedisch

HBO verpleegkunde $\quad 3.286$

HBO (fysio)therapie $\quad 3.933$

HBO voeding $\quad 3.086$

HBO radiologie $\quad 3.177$

\section{HBO Economie}

HBO accountancy en bedrijfseconomie $\quad 3.254$

HBO commerciële economie $\quad 3.285$

HBO toerisme en recreatie $\quad 2.835$

HBO recht en bestuur $\quad 3.086$

HBO secretariaat $\quad 3.112$

HBO bedrijfskunde $\quad 3.273$

\section{HBO Sociaal-cultureel}

HBO communicatie en journalistiek $\quad 3.451$

HBO maatschappelijk werk en hulpverlening $\quad 3.137$

HBO personeelswerk $\quad 3.393$

HBO bibliotheek en documentatie $\quad 3.214$ gemiddeld voor havo/vwo/mbo gemiddeld voor havo/vwo/mbo laag voor havo/vwo/mbo hoog voor havo/vwo/mbo hoog voor havo/vwo/mbo

laag voor havo/vwo/mbo
laag voor havo/vwo/mbo
gemiddeld voor havo/vwo/mbo
gemiddeld voor havo/vwo/mbo
gemiddeld voor havo/vwo/mbo

gemiddeld voor hbo gemiddeld voor hbo gemiddeld voor hbo gemiddeld voor hbo laag voor hbo

laag voor hbo gemiddeld voor hbo

gemiddeld voor hbo gemiddeld voor hbo gemiddeld voor hbo hoog voor hbo gemiddeld voor hbo hoog voor hbo gemiddeld voor hbo gemiddeld voor hbo

gemiddeld voor hbo hoog voor hbo gemiddeld voor hbo gemiddeld voor hbo

gemiddeld voor hbo gemiddeld voor hbo laag voor hbo gemiddeld voor hbo gemiddeld voor hbo gemiddeld voor hbo

hoog voor hbo gemiddeld voor hbo gemiddeld voor hbo gemiddeld voor hbo 
Tabel 3.14 (vervolg)

Gemiddeld bruto maandloon van werkzame schoolverlaters per opleidingsrichting, 1996

\begin{tabular}{lcl}
\hline Opleidingstype & $\begin{array}{c}\text { gemiddeld bruto } \\
\text { maandloon, } \\
\text { guldens }\end{array}$ & typering \\
\hline HBO sociaal-cultureel overig & 3.318 & gemiddeld voor hbo \\
HBO Kunst & 2.953 & laag voor hbo \\
HBO uitvoerende en beeldende kunsten & & \\
WO & 3.904 & \\
WO Economie & 3.724 & gemiddeld voor wo economie \\
WO econom(etr)ie & 3.983 & $\begin{array}{l}\text { gemiddeld voor wo economie } \\
\text { gemiddeld voor wo economie }\end{array}$ \\
WO bedrijfskunde & & Go accountancy en belastingen
\end{tabular}

Bron: ROA (schoolverlatersenquetes RUBS, HBO-Monitor, WO-economie scanner)

Toelichting:

Dit bruto maandloon is samengesteld op basis van een voltijdsaansteling. 
Tabel 3.15

Percentage werkzame schoolverlaters met een functie in de eigen vakrichting per opleidingsrichting, 1996

\begin{tabular}{lll}
\hline Opleidingstype & $\%$ & typering
\end{tabular}

VBO, MAVO

MAVO

MAVO

VBO Landbouw en natuurlijke omgeving

VBO landbouw en natuurlijke omgeving

erg laag

VBO Techniek

VBO bouwtechniek

VBO mechanische techniek

VBO motorvoertuigentechniek

VBO elektrotechniek

VBO horeca en levensmiddelentechniek

-

58

laag

VBO Economie

VBO administratie, handel en textiel

VBO Verzorging

VBO verzorging

MBO, HAVO/VWO

\section{HAVONWO \\ HAVONWO}

erg laag

MBO landbouw en natuurlijke omgeving

$\mathrm{KMBO}$ landbouw en veeteelt

$\mathrm{KMBO}$ milieu en groene ruimte

MBO landbouw en veeteelt

MBO milieu en groene ruimte

laag

56

76

laag

MBO Techniek

KMBO bouw

KMBO grond-, weg- en waterbouw

KMBO werktuigbouw en mechanische techniek

KMBO motorvoertuigentechniek

KMBO elektrotechniek

KMBO brood en banket

MBO bouw

MBO grond-, weg- en waterbouw

MBO installatietechniek

MBO werktuigbouw en mechanische techniek

MBO motorvoertuigentechniek

MBO elektrotechniek

MBO grafische techniek

MBO procestechniek

MBO levensmiddelentechniek/vleesverwerking

-

laag

-

MBO Dienstverlening en gezondheidszorg

$\begin{array}{ll}\text { KMBO verzorging } & 45 \\ \text { KMBO horeca } & 75 \\ \text { MBO dokters-, tandarts- en dierenartsassistent } & 86 \\ \text { MBO apothekersassistent } & 88 \\ \text { MBO verpleging } & 81 \\ \text { MBO sociaal-cultureel } & 72\end{array}$

erg laag 
Tabel 3.15 (vervolg)

Percentage werkzame schoolverlaters met een functie in de eigen vakrichting per opleidingsrichting, 1996

\begin{tabular}{lll}
\hline Opleidingstype & $\%$ & typering \\
\hline & & \\
MBO uiterlijke verzorging & 66 & laag \\
MBO horeca & 66 & laag \\
MBO beweging en therapie & 70 & gemiddeld \\
MBO Economie & & \\
KMBO administratie & 47 & laag \\
KMBO handel & 29 & erg laag \\
MBO administratie & 67 & laag \\
MBO handel & 53 & laag \\
MBO toerisme en recreatie & 70 & gemiddeld
\end{tabular}

HBO

HBO Onderwijs en tolk en vertaler

HBO lerarenopleiding basisonderwijs

$\mathrm{HBO}$ lerarenopleiding talen

HBO lerarenopleiding natuur en techniek $\quad 69$

HBO lerarenopleiding expressie $\quad 69$

$\mathrm{HBO}$ tolk en vertaler $\quad 44$

erg hoog

laag

gemiddeld

gemiddeld

erg laag

HBO Landbouw

$\mathrm{HBO}$ landbouw en veeteelt $\quad 75$

HBO milieukunde en levensmiddelentechnologie $\quad 77$

gemiddeld

gemiddeld

HBO Techniek
HBO laboratorium
HBO bouwkunde
HBO civiele techniek
HBO werktuigbouwkunde
HBO elektrotechniek
HBO informatica
HBO chemische technologie
HBO vervoer en logistiek

81

97

95

83

87

85

74

76

HBO Paramedisch

$H B O$ verpleegkunde

HBO (fysio)therapie

98

91

$\mathrm{HBO}$ voeding

HBO radiologie
HBO Economie
HBO accountancy en bedrijfseconomie
HBO commerciële economie
$\mathrm{HBO}$ toerisme en recreatie
$\mathrm{HBO}$ recht en bestuur
HBO secretariaat
HBO bedrijfskunde

HBO Sociaal-cultureel

HBO communicatie en journalistiek

HBO maatschappelijk werk en huipverlening

HBO personeelswerk

$\mathrm{HBO}$ bibliotheek en documentatie

$\mathrm{HBO}$ sociaal-cultureel overig

HBO Kunst

$\mathrm{HBO}$ uitvoerende en beeldende kunsten
86

69

43

52

61

68

68

82

70

77

77 hoog

erg hoog

erg hoog

hoog

hoog

hoog

gemiddeld

gemiddeld

erg hoog

erg hoog

gemiddeld

erg hoog

hoog

gemiddeld

erg laag

laag

laag

gemiddeld

gemiddeld

hoog

gemiddeld

gemiddeld

gemiddeld

gemiddeld 
Tabel 3.15 (vervolg)

Percentage werkzame schoolverlaters met een functie in de eigen vakrichting per opleidingsrichting, 1996

Opleidingstype

$\%$

typering

\section{wo}

WO Economie WO econom(etr)ie WO bedrijfskunde

WO accountancy en belastingen

77 gemiddeld

69 gemiddeld

74 gemiddeld

Bron: ROA (schoolverlatersenquêtes RUBS, HBO-Monitor, WO-economie scanner)

Toelichting:

De functie is een functie in de eigen vakrichting wanneer voor de functie de eigen of een verwante opleidingsrichting vereist is. 
Tabel 3.16

Onderbenutting van werkzame schoolverlaters per opleidingsrichting, 1996

\begin{tabular}{lll}
\hline Opleidingstype & $\%$ & typering \\
\hline
\end{tabular}

VBO, MAVO

MAVO

MAVO

erg laag

VBO Landbouw en natuurlijke omgeving

VBO landbouw en natuurlijke omgeving

VBO Techniek

VBO bouwtechniek

VBO mechanische techniek

VBO motorvoertuigentechniek

VBO elektrotechniek

VBO horeca en levensmiddelentechniek

24

$-$

$-$

0

VBO Economie

VBO administratie, handel en textiel

VBO Verzorging

VBO verzorging

MBO, HAVO/NWO

HAVONWO

HAVONWO

MBO landbouw en natuurlijke omgeving

KMBO landbouw en veeteelt

KMBO milieu en groene ruimte

$M B O$ landbouw en veeteelt

MBO milieu en groene ruimte

MBO Techniek

KMBO bouw

KMBO grond-, weg- en waterbouw

KMBO werktuigbouw en mechanische techniek

KMBO motorvoertuigentechniek

KMBO elektrotechniek

KMBO brood en banket

MBO bouw

$\mathrm{MBO}$ grond-, weg- en waterbouw

$\mathrm{MBO}$ installatietechniek

MBO werktuigbouw en mechanische techniek

MBO motorvoertuigentechniek

MBO elektrotechniek

MBO grafische techniek

MBO procestechniek

MBO levensmiddelentechniek/vleesverwerking

MBO Dienstverlening en gezondheidszorg

$\mathrm{KMBO}$ verzorging

45

56

45

45
37

53

42

39

$-$

44

$-$

22

17

61

35

75

25

21

38

44

57

33

25

24

27

24

54 hoog

laag

-

erg laag

gemiddeld

erg laag

erg hoog

hoog

gemiddeld

hoog

hoog

gemiddeld

hoog

-

laag

erg laag

erg hoog

gemiddeld

erg hoog

laag

laag

gemiddeld

hoog

erg hoog

gemiddeld

laag

laag

gemiddeld

laag

hoog 
Tabel 3.16 (vervolg)

Onderbenutting van werkzame schoolverlaters per opleidingsrichting, 1996

\begin{tabular}{lcc}
\hline Opleidingstype & $\%$ & typering \\
\hline & & \\
MBO uiterlijke verzorging & 45 & hoog \\
MBO horeca & 42 & hoog \\
MBO beweging en therapie & 21 & \\
& & laag \\
MBO Economie & 42 & hoog \\
KMBO administratie & 64 & gemiddeld \\
KMBO handel & 32 & hoog \\
MBO administratie & 43 & laag \\
MBO handel & 25 &
\end{tabular}

\section{HBO}

$H B O$ Onderwijs en tolk en vertaler HBO lerarenopleiding basisonderwijs HBO lerarenopleiding talen

HBO lerarenopleiding natuur en techniek

HBO lerarenopleiding expressie

HBO Techniek

$\mathrm{HBO}$ laboratorium $\quad 30$

HBO bouwkunde $\quad 36$

hoog

HBO civiele techniek

HBO werktuigbouwkunde

HBO elektrotechniek

$\mathrm{HBO}$ informatica

HBO chemische technologie

HBO vervoer en logistiek

HBO Paramedisch

$\mathrm{HBO}$ verpleegkunde

HBO (fysio)therapie

$\mathrm{HBO}$ voeding

HBO radiologie

gemiddeld gemiddeld gemiddeld gemiddeld laag erg laag gemiddeld hoog

\section{HBO Economie}

HBO accountancy en bedrijfseconomie $\quad 27$

HBO commerciële economie 38

HBO toerisme en recreatie $\quad 54$

HBO recht en bestuur 48

$\mathrm{HBO}$ secretariaat $\quad 55$

HBO bedrijfskunde 33

laag

erg laag

laag

erg laag

HBO Sociaal-cultureel

HBO communicatie en journalistiek 28

HBO maatschappelijk werk en hulpverlening $\quad 40$

gemiddeld gemiddeld

hoog

hoog

erg hoog 
Tabe/ 3.16 (vervolg)

Onderbenutting van werkzame schoolverlaters per opleidingsrichting, 1996

\begin{tabular}{lll}
\hline Opleidingstype & $\%$ & typering \\
\hline WO & & \\
WO Economie & & \\
WO econom(etr)ie & 53 & hoog \\
WO bedrijfskunde & 60 & erg hoog \\
WO accountancy en belastingen & 17 & erg laag
\end{tabular}

Bron: ROA (schoolverlatersenquêtes RUBS, HBO-Monitor, WO-economie scanner)

Toelichting:

Onderbenutting wordt bepaald op basis van het opleidingsniveau dat volgens de schoolverlaters vereist is voor de door hen uitgeoefende functie. 


\section{BASISONDERWIJS}

\section{Basisonderwijs}

Chauffeurs

Interieurverzorgers

Bouwvakkers

Productiemedewerkers

Hulpkrachten horeca en verzorging

Andere beroepsgroepen

constant

constant

dalend

constant

constant

VBO, MAVO

MAVO

Receptionisten en administratieve employés

dalend

Verkopers

Commercieel employés

Boekhouders en secretaresses

constant

dalend

Andere beroepsgroepen

constant

VBO landbouw en natuurlijke omgeving

Agrarische bedrijfshoofden

Agrarische arbeiders

Chauffeurs

Andere beroepsgroepen

dalend

constant

dalend

VBO bouwtechniek

Bouwvakkers

Aannemers en installateurs

Chauffeurs

Andere beroepsgroepen

constant constant dalend

VBO installatietechniek

Aannemers en installateurs

Andere beroepsgroepen

VBO mechanische techniek

\section{Metaalarbeiders}

Monteurs

Chauffeurs

Aannemers en installateurs

Bouwvakkers

Andere beroepsgroepen

dalend

VBO fijnmechanische techniek Diverse beroepsgroepen

constant

VBO motorvoertuigentechniek

Monteurs

Chauffeurs

Metaalarbeiders

Andere beroepsgroepen 
Tabel 3.17 (vervolg)

Belangrijkste beroepsgroepen per opleidingstype, gemiddelde 1995-1996

Opleidingstype

Chauffeurs

Monteurs en controleurs elektrotechnische producten

\section{8}

6

Andere beroepsgroepen

Diverse beroepsgroepen

VBO brood en banket

Mechanisch operators

Andere beroepsgroepen

constant

VBO horeca en levensmiddelentechniek

Hulpkrachten horeca en verzorging

Mechanisch operators

Andere beroepsgroepen

VBO vervoer

Chauffeurs

Laders en lossers

Andere beroepsgroepen

VBO administratie, handel en textiel

\section{Verkopers}

Receptionisten en administratieve employés

Hulpkrachten horeca en verzorging

Boekhouders en secretaresses

Interieurverzorgers

Andere beroepsgroepen

\section{VBO verzorging}

Verkopers

Interieurverzorgers

Hulpkrachten horeca en verzorging

Receptionisten en administratieve employés

Andere beroepsgroepen

VBO beveiliging

Aspirant politieagenten, soldaten en beveiligingshulpkrachten

-

$-$

constant dalend -

constant sterk stijgend

\section{MBO/LLW, HAVO/VWO}

\section{HAVONWO}

Boekhouders en secretaresses

Commercieel employés

Verkopers

Andere beroepsgroepen

constant stijgend dalend dalend

MBO/LLW landbouw en veeteelt Agrarische bedrijfshoofden Agrarische arbeiders 


\section{MBO/LLW laboratorium}

Laboranten

Apothekersassistenten en medisch laboranten

MBO/LLW bouw

Aannemers en installateurs

Bouwvakkers

Andere beroepsgroepen

MBO/LLW grond-, weg-en waterbouw

Weg-en waterbouwkundige vakkrachten

Weg-en waterbouwkundige arbeiders

Aannemers en installateurs

Andere beroepsgroepen

MBO/LLW installatietechniek

Aannemers en installateurs

MBO/LLW werktuigbouw en mechanische techniek

Monteurs

Bankwerkers en lassers

Metaalarbeiders

Aannemers en installateurs

Andere beroepsgroepen

MBO/LLW fijnmechanische techniek

Bankwerkers en lassers

MBO/LLW motorvoertuigentechniek

Monteurs

Chauffeurs

Andere beroepsgroepen

MBO/LLW vliegtuigtechniek

Monteurs

Andere beroepsgroepen

MBO/LLW operationele techniek

Monteurs

Andere beroepsgroepen

MBO/LLW elektrotechniek

Elektromonteurs

Monteurs

Andere beroepsgroepen

MBO/LLW grafische techniek

constant

dalend stijgend stijgend

stijgend

constant constant constant stijgend

constant -

constant constant -

-

sterk dalend

constant dalend constant constant 
Tabel 3.17 (vervolg)

Belangrijkste beroepsgroepen per opleidingstype, gemiddelde 1995-1996

Opleidingstype

\section{MBO/LLW procestechniek}

Procesoperators

Mechanisch operators

Andere beroepsgroepen

stijgend

dalend

MBO/LLW brood en banket

Bakkers en slagers

Procesoperators

dalend

Andere beroepsgroepen

stijgend

MBO/LLW levensmiddelentechniek/vleesverwerking

Mechanisch operators

Bakkers en slagers

\section{MBO $L L W$ vervoer}

Chauffeurs

Rij-instructeurs

Administratieve transportemployés

Schippers en conducteurs

Monteurs

Productieplanners

Andere beroepsgroepen

MBO dokters-, tandarts- en dierenartsassistent Verplegenden en doktersassistenten

MBO/LLW apothekersassistent

Apothekersassistenten en medisch laboranten

$M B O / L L W$ verpleging

Verplegenden en doktersassistenten

dalend

dalend stijgend dalend sterk stijgend sterk stijgend

Verzorgend personeel

Therapeuten en verpleegkundigen

Andere beroepsgroepen

$M B O / L L W$ gezondheidstechniek

Apothekersassistenten en medisch laboranten

constant

Andere beroepsgroepen

MBO sociaal-cultureel

Verzorgend personeel

Boekhouders en secretaresses

dalend sterk stijgend dalend

\section{$M B O / L L W$ verzorging}

Verzorgend personeel

stijgend stijgend constant stijgend stijgend 
Tabel 3.17 (vervolg)

Belangrijkste beroepsgroepen per opleidingstype, gemiddelde 1995-1996

Opleidingstype

$\% \quad$ trend

1992-'96

Hulpkrachten horeca en verzorging

sterk stijgend

Boekhouders en secretaresses

stijgend

Andere beroepsgroepen

MBO/LLW uiterlijke verzorging

Verzorgend personeel

Verkopers

Boekhouders en secretaresses

Andere beroepsgroepen

MBO/LLW horeca

Verzorgend personeel

Bedrijfshoofden horeca

Hulpkrachten horeca en verzorging

Andere beroepsgroepen

constant constant stijgend

dalend

stijgend constant

$M B O / L L W$ beweging en therapie

Activiteitenbegeleiders en medewerkers arbeidsbemiddeling

stijgend

Verplegenden en doktersassistenten

Andere beroepsgroepen

constant

MBO/LLW administratie

Boekhouders en secretaresses

Commercieel employés

Receptionisten en administratieve employés

Assistent accountants

Andere beroepsgroepen

constant constant dalend dalend

MBO/LLW handel

Winkeliers

Verkopers

Commercieel employés

Boekhouders en secretaresses

Commercieel medewerkers

Andere beroepsgroepen

$M B O / L L W$ secretariaat

Boekhouders en secretaresses

Receptionisten en administratieve employés

Medisch secretaresses

Commercieel employés

constant

Andere beroepsgroepen

dalend constant dalend

$M B O / L L W$ toerisme en recreatie

Commercieel employés

stijgend dalend constant constant

Boekhouders en secretaresses

Receptionisten en administratieve employés -

Andere beroepsgroepen

constant constant stijgend

MBO/LLW bedrijfskunde

Boekhouders en secretaresses

stijgend

Commercieel employés

constant

Andere beroepsgroepen 
MBO/LLW automatisering

Programmeurs

Boekhouders en secretaresses

constant

Systeemanalisten

stijgend

Andere beroepsgroepen

constant

MBO/LLW geld, bank en belastingen

Juridisch en fiscaal medewerkers

Commercieel employés

Commercieel medewerkers

Boekhouders en secretaresses

Andere beroepsgroepen

dalend

constant

dalend

stijgend

$M B O$ verzekeringswezen

Commercieel employés

Commercieel medewerkers

Andere beroepsgroepen

stijgend

dalend

$M B O$ openbare orde en veiligheid

Politieagenten, onderofficieren en beveiligingsemployés

Aspirant politieagenten, soldaten en beveiligingshulpkrachten

HBO

$H B O$ lerarenopleiding basisonderwijs

Leraar basisonderwijs

Andere beroepsgroepen

constant

HBO lerarenopleiding talen

Docenten talen en expressie

Docenten letteren ( 1 e graads)

Andere beroepsgroepen

HBO lerarenopleiding natuur en techniek

Docenten landbouw en techniek (2e graads) $-$

Docenten exacte, medische en verzorgende vakken (2e graads)

Docenten exacte, medische en verzorgende vakken (1e graads)

Docenten $2 \mathrm{e}$ graads zonder specialisatie

Andere beroepsgroepen

constant stijgend stijgend stijgend

HBO lerarenopleiding economie en maatschappij

Leraar basisonderwijs

Docenten economisch-administratieve vakken (2e graads)

Docenten $2 \mathrm{e}$ graads zonder specialisatie

Sociaal-cultureel werkers

Andere beroepsgroepen

HBO lerarenopleiding lichamelijke opvoeding

Docenten sociale vakken (2e graads)

Andere beroepsgroepen

dalend

-

HBO lerarenopleiding medisch en verzorging

Docenten exacte, medische en verzorgende vakken ( 2 e graads)

Andere beroepsgroepen 
HBO lerarenopleiding expressie

Docenten talen en expressie

Leraar basisonderwijs

Docenten letteren (1e graads)

Andere beroepsgroepen

HBO tolk en vertaler

Diverse beroepsgroepen

HBO landbouw en veeteelt

Diverse beroepsgroepen

HBO milieukunde en levensmiddelentechnologie

Milieuhygiënisten en agrarisch vertegenwoordigers

Andere beroepsgroepen

constant

HBO laboratorium

Medisch analisten

Technisch analisten

Andere beroepsgroepen

HBO bouwkunde

Architecten en bouwkundig projectleiders

Aannemers en installateurs

HBO civiele techniek

Weg-en waterbouwkundig ontwerpers en projectleiders -

Andere beroepsgroepen

constant

HBO werktuigbouwkunde

Werktuigbouwkundig ontwerpers en hoofden technische dienst

Commercieel medewerkers

Monteurs

Technisch-bedrijfskundig medewerkers

Andere beroepsgroepen

HBO elektrotechniek

Systeemanalisten

Elektrotechnisch ontwerpers en bedrijfshoofden

\section{HBO informatica}

Systeemanalisten

Technisch systeemanalisten

Andere beroepsgroepen

HBO chemische technologie

Diverse beroepsgroepen 


\section{HBO verpleegkunde}

Therapeuten en verpleegkundigen

Verplegenden en doktersassistenten

Managers

Andere beroepsgroepen

constant

dalend

stijgend

HBO (fysio)therapie

Therapeuten en verpleegkundigen

Andere beroepsgroepen

constant

$H B O$ voeding

$H B O$ radiologie

Medisch analisten

69

Andere beroepsgroepen

constant

HBO accountancy en bedrijfseconomie

Assistent accountants

Accountants

Boekhouders en secretaresses

Commercieel medewerkers

Systeemanalisten

Andere beroepsgroepen

HBO commerciële economie

Commercieel medewerkers

Commercieel employés

HBO toerisme en recreatie

Commercieel employés

constant

HBO recht en bestuur

Juristen

Andere beroepsgroepen

dalend

HBO secretariaat

Boekhouders en secretaresses

Assistent accountants

Commercieel employés

Andere beroepsgroepen

HBO bedrijfskunde

Commercieel medewerkers

Commercieel employés

Organisatie-adviseurs

Boekhouders en secretaresses

Leidinggevenden

Managers

Andere beroepsgroepen

constant constant constant dalend constant stijgend stige

HBO communicatie en journalistiek Journalisten

dalend stijgend constant -

constant constant dalend sterk stijgend sterk stijgend dalend -

constant 
HBO maatschappelijk werk en hulpverlening

Sociaal-cultureel werkers

constant

Verzorgend personeel

Activiteitenbegeleiders en medewerkers arbeidsbemiddeling

HBO personeelswerk

Sociaal-cultureel werkers

Andere beroepsgroepen

50

50

HBO bibliotheek en documentatie

Bibliothecarissen

60

40

Andere beroepsgroepen

Andere beroepsgroepen

HBO openbare orde en veiligheid

Diverse beroepsgroepen

\section{wo}

WO letteren

Docenten letteren (1e graads)

Tolken, vertalers en schrijvers

Taalkundigen

Andere beroepsgroepen

WO theologie

Geestelijken

Andere beroepsgroepen

WO landbouw en milieukunde

Diverse beroepsgroepen

WO wiskunde en natuurwetenschappen

Docenten exacte, medische en verzorgende vakken (1e graads)

Natuurwetenschappers

Materiaalkundigen

Systeemanalisten

Andere beroepsgroepen

WO bouwkunde

Weg- en waterbouwkundigen

Andere beroepsgroepen 
Tabel 3.17 (vervolg)

Belangrijkste beroepsgroepen per opleidingstype, gemiddelde 1995-1996

Opleidingstype

$\%$

trend

1992-'96

WO werktuigbouwkunde

Diverse beroepsgroepen

100

Wo elektrotechniek

Diverse beroepsgroepen

100

WO informatica en bestuurlijke informatiekunde

Systeemanalisten

43

Andere beroepsgroepen

57

WO (dier)geneeskunde

Artsen

86

Andere beroepsgroepen

constant

WO tandheelkunde

Artsen

92

Andere beroepsgroepen

WO farmacie

Apothekers

Andere beroepsgroepen

WO econom(etr)ie

Commercieel medewerkers

Economen

Assistent accountants

Managers

Accountants

Organisatiedeskundigen

Commercieel employés

Andere beroepsgroepen

WO bedrijfskunde

Organisatiedeskundigen

Andere beroepsgroepen

dalend

constant -

dalend

WO accountancy en belastingen

Accountants

Assistent accountants

constant dalend constant stijgend stijgend constant sterk stijgend

Andere beroepsgroepen

constant constant constant

WO rechten en bestuurskunde Juristen

Managers

Commercieel medewerkers

Andere beroepsgroepen

WO sociale wetenschappen

Sociaal-wetenschappelijk onderzoekers

constant Onderwijskundigen en pedagogen

Managers 
Tabel 3.17 (vervolg)

Belangrijkste beroepsgroepen per opleidingstype, gemiddelde 1995-1996

Opleidingstype

$\%$

trend

1992-'96

WO kunstwetenschappen

Diverse beroepsgroepen

100 
Tabel 3.18

Uitwijkmogelijkheden naar verschillende beroepsgroepen per opleidingstype, gemiddeld 1995-1996

Opleidingstype

spreidingsindex

typering

\section{BASISONDERWIJS}

Basisonderwijs

20,56

erg hoog

MAVO, VBO

MAVO

MAVO

19,08

erg hoog

VBO Landbouw en natuurlijke omgeving

VBO landbouw en natuurlijke omgeving

VBO bouwtechniek

VBO installatietechniek

VBO mechanische techniek

VBO fijnmechanische techniek

VBO motorvoertuigentechniek

VBO elektrotechniek

VBO grafische techniek

VBO brood en banket

VBO horeca en levensmiddelentechniek

VBO vervoer

$\begin{aligned} 6,18 & \text { gemiddeld } \\ 4,82 & \text { laag } \\ 6,60 & \text { gemiddeld } \\ 10,66 & \text { hoog } \\ 15,24 & \text { hoog } \\ 9,53 & \text { gemiddeld } \\ 12,67 & \text { hoog } \\ 6,51 & \text { gemiddeld } \\ 11,61 & \text { hoog } \\ 11,48 & \text { hoog } \\ 2,17 & \text { erg laag }\end{aligned}$

VBO Economie

VBO administratie, handel en textiel

14,42

hoog

VBO Verzorging

VBO verzorging

11,03

hoog

VBO Openbare orde en veiligheid

VBO beveiliging

3,84

laag

HAVO/VWO, MBO/LLW

HAVONWO
HAVONWO

16,78

hoog

MBO/LLW Landbouw en natuurlijke omgeving

MBO/LLW landbouw en veeteelt

$4,61 \quad$ laag

MBO/LLW milieu en groene ruimte

laag

MBO/LLW Techniek

MBO/LLW laboratorium

MBO/LLW bouw

gemiddeld

MBO/LLW grond-, weg- en waterbouw

laag

MBO/LLW installatietechniek

MBO/LLW werktuigbouw en mechanische techniek

9,05

MBO/LLW fijnmechanische techniek

9,52

MBO/LLW motorvoertuigentechniek

4,09

MBO/LLW vliegtuigtechniek

MBO/LLW operationele techniek

5,42

5,30

MBO/LLW elektrotechniek

7,07

MBO/LLW grafische techniek

MBO/LLW procestechniek

5,21

3,71

MBO/LLW brood en banket

MBO/LLW levensmiddelentechniek/vleesverwerking 
Tabel 3.18 (vervolg)

Uitwijkmogelijkheden naar verschillende beroepsgroepen per opleidingstype, gemiddeld 1995-1996

MBO Dienstverlening en gezondheidszorg

MBO dokters-, tandarts- en dierenartsassistent

MBO/LLW apothekersassistent

MBO/LLW gezondheidstechniek

MBO sociaal-cultureel

$\mathrm{MBO} / \mathrm{LLW}$ verzorging

MBO/LLW uiterlijke verzorging

MBO/LLW horeca

MBO/LLW beweging en therapie

MBO/LLW administratie

MBO/LLW handel

MBO/LLW secretariaat

MBO/LLW toerisme en recreatie

MBO/LLW bedrijfskunde

MBO/LLW automatisering

MBO/LLW geld, bank en belastingen

$M B O$ verzekeringswezen

MBO Openbare orde en veiligheid

MBO openbare orde en veiligheid
$M B O / L L W$ verpleging

\section{MBO/LLW Economie}

$\begin{array}{ll}2,55 & \text { erg laag } \\ 1,67 & \text { erg laag } \\ 3,17 & \text { erg laag } \\ 1,83 & \text { erg laag } \\ 9,58 & \text { gemiddeld } \\ 6,54 & \text { gemiddeld } \\ 3,41 & \text { erg laag } \\ 7,95 & \text { gemiddeld } \\ 9,34 & \text { gemiddeld }\end{array}$

6,06

12,86

3,75

4,82

21,32

7,53

5,56

2,71

6,52

gemiddeld

hoog

laag

laag

erg hoog

gemiddeld

gemiddeld

erg laag

gemiddeld

HBO

HBO Onderwijs en tolk en vertaler

HBO lerarenopleiding basisonderwijs

HBO lerarenopleiding taien

1,95

4,92

8,03

16,22

HBO lerarenopleiding economie en maatschappij

4,34

HBO lerarenopleiding lichamelijke opvoeding

HBO lerarenopleiding medisch en verzorging

6,34

9,05

14,99

$\mathrm{HBO}$ tolk en vertaler

7,86

14,37

gemiddeld
hoog

HBO landbouw en veeteelt

HBO milieukunde en levensmiddelentechnologie

9,13

4,89

10,45

11,86

13,40

2,92

12,46

8,82

erg laag

laag

gemiddeld

hoog

laag

gemiddeld

gemiddeld

hoog

HBO bouwkunde

HBO civiele techniek

HBO elektrotechniek

HBO informatica

HBO chemische technologie

HBO vervoer en logistiek

gemiddeld

laag

gemiddeld

hoog

hoog

erg laag

hoog

gemiddeld

HBO Paramedisch

$\mathrm{HBO}$ verpleegkunde

HBO (fysio)therapie

erg laag

$\mathrm{HBO}$ voeding

$\mathrm{HBO}$ radiologie 


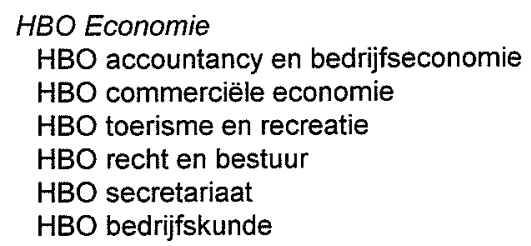

\section{HBO Sociaal-cultureel}

HBO communicatie en journalistiek

HBO maatschappelijk werk en hulpveriening

HBO personeelswerk

HBO bibliotheek en documentatie

$\begin{aligned} 6,01 & \text { gemiddeld } \\ 5,66 & \text { gemiddeld } \\ 7,96 & \text { gemiddeld } \\ 17,71 & \text { erg hoog } \\ 5,51 & \text { gemiddeld } \\ 17,54 & \text { erg hoog }\end{aligned}$

HBO Kunst

HBO uitvoerende en beeldende kunsten

5,49

5,92

3,74

2,55

laag

gemiddeld

laag

erg laag

HBO Openbare orde en veiligheid

$\mathrm{HBO}$ openbare orde en veiligheid

$\begin{array}{ll}4,78 & \text { laag } \\ 9,17 & \text { gemiddeld }\end{array}$

wo

WO Letteren en theologie

WO letteren

WO theologie

8,78

3,16

gemiddeld

WO Landbouw en milieukunde

erg hoog

WO Techniek

WO wiskunde en natuurwetenschappen

WO bouwkunde

WO civiele techniek

WO werktuigbouwkunde

WO elektrotechniek

WO informatica en bestuurlijke informatiekunde

$\begin{aligned} 12,76 & \text { hoog } \\ 3,74 & \text { laag } \\ 7,51 & \text { gemiddeld } \\ 13,12 & \text { hoog } \\ 9,03 & \text { gemiddeld } \\ 3,67 & \text { laag }\end{aligned}$

WO Medisch

WO (dier)geneeskunde

1,29

erg laag

WO tandheelkunde

1,17

erg laag

WO farmacie

WO Economie

WO econom(etr)ie

WO bedrijfskunde

14,08

13,27

WO accountancy en belastingen

3,65

WO rechten en bestuurskunde

3,45 erg laag

WO Sociaal-cultureel

WO sociale wetenschappen

$15,78 \quad$ hoog

WO Kunst

WO kunstwetenschappen 
Toelichting:

De indicator voor uitwijkmogelijkheden geeft aan in welke mate arbeidskrachten met een bepaalde opleiding terecht kunnen komen in andere beroepsgroepen. Deze maatstaf geeft daarmee aan in hoeverre arbeidskrachten afhankelijk zijn van de arbeidsmarktsituatie in een bepaalde beroepsgroep. De uitwijkmogelijkheden worden bepaald met behulp van de Gini-Hirschman-spreidingsindex. Deze indicator kan geïnterpreteerd worden als een genormeerd aantal beroepsgroepen waarin mensen met dit opleidingstype werkzaam zijn. 
Tabel 3.19

Belangrijkste bedrijfssectoren per opleidingstype, gemiddelde 1995-1996

Opleidingstype

$\%$

\section{BASISONDERWIJS}

\author{
Basisonderwijs \\ Handel \\ Bouw \\ Metaalproducten \\ Zakelijke dienstverlening \\ Weg-en railvervoer \\ Gezondheidszorg \\ Andere bedrijfssectoren
}

16

10

9

7

7

7

44

\section{VBO, MAVO}

MAVO

Handel

Gezondheidszorg

Zakelijke dienstverlening

Overheid

Weg-en railvervoer

Andere bedrijfssectoren

22

9

8

8

5

48

VBO landbouw en natuurlijke omgeving

Veehouderij

Tuinbouw

Handel

Bouw

Andere bedrijfssectoren

VBO bouwtechniek

Bouw

Metaalproducten

Handel

Andere bedrijfssectoren

VBO installatietechniek

Bouw

Andere bedrijfssectoren

VBO mechanische techniek

Metaalproducten

Bouw

Machine-industrie

Handel

Weg- en railvervoer

Transportmiddelen

Andere bedrijfssectoren

VBO fijnmechanische techniek

Diverse bedrijfssectoren

VBO motorvoertuigentechniek

Reparatie

Handel

Weg- en railvervoer

Bouw

38

41

9

9

41

50

50 trend
$1994-' 96$

trend
$1994-' 96$ stijgend

constant

constant

stijgend

dalend

constant

constant

constant sterk stijgend

constant

constant

-

constant

sterk stijgend sterk stijgend

constant

stijgend

constant

constant

constant

-

-

stijgend

dalend

sterk stijgend

stijgend

stijgend

dalend

-

sterk dalend

constant

stijgend

sterk stijgend 
Tabel 3.19 (vervolg)

Belangrijkste bedrijfssectoren per opleidingstype, gemiddelde 1995-1996

Opleidingstype

trend

1994-'96

Metaalproducten
Andere bedrijfssectoren
VBO elektrotechniek
Bouw
Handel
Weg- en railvervoer
Elektrotechniek
Overheid
Andere bedrijfssectoren
VBO grafische techniek
Grafische industrie
Andere bedrijfssectoren
VBO brood en banket
Overige voedingsproducten
Andere bedrijfssectoren

sterk stijgend

VBO elektrotechniek

Bouw

VBO horeca en levensmiddelentechniek

\section{Horeca}

sterk stijgend

Handel

Gezondheidszorg

Andere bedrijfssectoren

dalend

VBO vervoer

Weg- en railvervoer

Handel

Andere bedrijfssectoren

stijgend

dalend

sterk stijgend

sterk dalend

sterk stijgend

VBO administratie, handel en textiel

Handel

Gezondheidszorg

Zakelijke dienstverlening

Overheid

Andere bedrijfssectoren

-

VBO verzorging

Handel

Gezondheidszorg

Zakelijke dienstverlening

sterk dalend stijgend dalend

Horeca

Andere bedrijfssectoren

-

constant stijgend

VBO beveiliging

Zakelijke dienstverlening

Andere bedrijfssectoren

constant

\section{MBO/LLW, HAVONWO}

\section{HAVO/VWO}

Handel 
Tabel 3.19 (vervoig)

Belangrijkste bedrijfssectoren per opleidingstype, gemiddelde 1995-1996

Opleidingstype

$\% \quad$ trend

1994-'96

Bankwezen

Horeca

Andere bedrijfssectoren

constant

sterk dalend

$M B O / L L W$ landbouw en veeteelt

Veehouderij

Tuinbouw

Handel

Akkerbouw, bosbouw en visserij

Andere bedrijfssectoren

MBO/LLW milieu en groene ruimte

Overheid

Veehouderii

Andere bedrijfssectoren

\section{MBO/LLW laboratorium}

Gezondheidszorg

Andere bedrijfssectoren

\section{MBO/LLW bouw}

\section{Bouw}

Zakelijke dienstverlening

Metaalproducten

Handel

Andere bedrijfssectoren

$M B O / L L W$ grond-, weg-en waterbouw

\section{Bouw}

Overheid

Zakelijke dienstverlening

Andere bedrijfssectoren

MBO/LLW installatietechniek

\section{Bouw}

Andere bedrijfssectoren
MBO/LLW werktuigbouw en mechanische techniek

Metaalproducten

Machine-industrie

Handel

Bouw

Transportmiddelen

Andere bedrijfssectoren

MBO/LLW fijnmechanische techniek

Handel

Andere bedrijfssectoren

MBO/LLW motorvoertuigentechniek

Reparatie

Handel

Weg-en railvervoer

Andere bedrijfssectoren dalend

dalend

sterk stijgend

constant

sterk dalend

constant

constant

-

dalend

sterk stijgend

dalend

stijgend

stijgend

sterk dalend

sterk stijgend

stijgend

stijgend

stijgend

dalend

sterk stijgend

dalend

sterk dalend

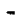

constant

constant

constant 
MBO/LLW vliegtuigtechniek

Diverse bedrijfssectoren

MBO/LLW operationele techniek

Bouw

sterk stijgend

Andere bedrijfssectoren

MBO/LLW elektrotechniek

\section{Bouw}

Handel

Elektrotechniek

Zakelijke dienstverlening

Communicatie

Energie

Andere bedrijfssectoren

MBO/LLW grafische techniek

Grafische industrie

Zakelijke dienstverlening

Handel

Andere bedrijfssectoren

MBO/LLW procestechniek

Basischemie

Andere bedrijfssectoren

MBO/LLW brood en banket

Overige voedingsproducten

Andere bedrijfssectoren

MBO/LLW levensmiddelentechniek/vleesvenwerking

Handel

Overige voedingsproducten

Andere bedriifssectoren

\section{$M B O / L L W$ vervoer}

Weg- en railvervoer

Handel

Onderwijs

Scheeps- en luchtvaart

Communicatie

Andere bedrijfssectoren

MBO dokters-, tandarts- en dierenartsassistent

Gezondheidszorg

Andere bedrijfssectoren

MBO/LLW apothekersassistent

Handel

Gezondheidszorg

Andere bedrijfssectoren

MBO/LLW verpleging

Gezondheidszorg

Andere bedrijfssectoren

$$
\text { - }
$$

stijgend constant sterk stijgend sterk dalend -

dalend dalend dalend stijgend sterk stijgend dalend dalend sterk dalend -

constant

dalend sterk stijgend 


\section{MBO/LLW gezondheidstechniek}

Handel

Andere bedrijfssectoren

MBO sociaal-cultureel

Gezondheidszorg

Overheid

Handel

Zakelijke dienstverlening

Andere bedrijfssectoren

MBO/LLW verzorging

Gezondheidszorg

Handel

Andere bedrijfssectoren

MBO/LLW uiterlijke verzorging

Overige commerciële dienstverlening

Handel

Gezondheidszorg

Andere bedrijfssectoren

\section{MBO/LLW horeca}

Horeca

Gezondheidszorg

Handel

Andere bedrijfssectoren

MBO/LLW beweging en therapie

Gezondheidszorg

Overige kwartaire diensten

Andere bedrijfssectoren

MBO/LLW administratie

Handel

Overheid

Zakelijke dienstverlening

Bankwezen

Andere bedrijfssectoren

\section{MBO/LLW handel}

Handel

Zakelijke dienstverlening

Andere bedrijfssectoren

\section{$M B O / L L W$ secretariaat}

Gezondheidszorg

Zakelijke dienstverlening

Handel

Overheid

Andere bedrijfssectoren

MBO/LLW toerisme en recreatie

Weg- en railvervoer

Andere bedrijfssectoren dalend

stijgend sterk dalend sterk stijgend sterk stijgend -

dalend stijgend

dalend sterk stijgend sterk dalend$$
\text { - }
$$

dalend constant constant -

constant constant

constant sterk dalend stijgend sterk stijgend

stijgend constant

stijgend constant dalend dalend -

constant 
Tabe/ 3.19 (vervolg)

Belangrijkste bedrijfssectoren per opleidingstype, gemiddelde 1995-1996

Opleidingstype

$\%$

trend

1994-'96

\section{$M B O / L L W$ bedrijfskunde \\ Handel \\ Overheid \\ Zakelijke dienstverlening \\ Metaalproducten \\ Andere bedrijfssectoren}

MBO/LLW automatisering

constant

dalend

sterk stijgend

sterk dalend

Zakelijke dienstverlening

Handel

Overheid

Andere bedrijfssectoren

MBO/LLW geld, bank en belastingen

Overheid

Bankwezen

Andere bedrijfssectoren

$M B O$ verzekeringswezen

Verzekeringswezen

Bankwezen

Andere bedrijfssectoren

MBO openbare orde en veiligheid

Overheid

Handel

Weg- en railvervoer

Andere bedrijfssectoren .

dalend

sterk stijgend sterk dalend

-

sterk stijgend sterk dalend

-

stijgend sterk dalend

-

constant sterk stijgend constant

HBO

HBO lerarenopleiding basisonderwijs

Onderwijs

Gezondheidszorg

Overheid

Andere bedrijfssectoren

HBO lerarenopleiding talen

Onderwijs

Andere bedrijfssectoren

HBO lerarenopleiding natuur en techniek

Onderwijs

Andere bedrijfssectoren

HBO lerarenopleiding economie en maatschappij

Onderwijs

Gezondheidszorg

Overheid

Zakelijke dienstverlening

Andere bedrijfssectoren

HBO lerarenopleiding lichamelijke opvoeding

Andere bedrijfssectoren constant

constant constant

$-$

dalend

-

constant

-

dalend

sterk dalend stijgend sterk stijgend

$-$

stijgend 
HBO lerarenopleiding medisch en verzorging

\section{Onderwijs}

Gezondheidszorg

Andere bedriifssectoren

\section{HBO lerarenopleiding expressie}

Onderwijs

Overige kwartaire diensten

Gezondheidszorg

Andere bedrijfssectoren

\section{HBO tolk en vertaler}

Diverse bedrijfssectoren

HBO landbouw en veeteelt

Diverse bedrijfssectoren

HBO milieukunde en levensmiddelentechnologie Overheid

Zakelijke dienstverlening

Andere bedrijfssectoren

HBO laboratorium

Gezondheidszorg

Onderwijs

Eindproducten chemie

Zakelijke dienstverlening

Andere bedrijfssectoren

HBO bouwkunde

Zakelijke dienstverlening

Bouw

Overheid

Andere bedrijfssectoren

HBO civiele techniek

Overheid

Zakelijke dienstverlening

Bouw

Andere bedrijfssectoren

HBO werktuigbouwkunde

Zakelijke dienstverlening

Machine-industrie

Handel

Elektrotechniek

Andere bedrijfssectoren

HBO elektrotechniek

Zakelijke dienstverlening

Elektrotechniek

Handel

Bouw

Andere bedrijfssectoren 
Tabel 3.19 (vervolg)

Belangrijkste bedrijfssectoren per opleidingstype, gemiddelde 1995-1996

Opleidingstype

$\%$

trend

1994-'96

HBO informatica
Zakelijke dienstverlening
Handel
Overheid
Andere bedrijfssectoren
HBO chemische technologie
Diverse bedrijfssectoren

stijgend

stijgend

sterk dalend

-

HBO vervoer en logistiek

Scheeps- en luchtvaart

Weg-en railvervoer

26

13

Energie

Overheid

Andere bedrijfssectoren

HBO verpleegkunde

Gezondheidszorg

Andere bedrijfssectoren

HBO (fysio) therapie

Gezondheidszorg

Onderwijs

Andere bedrijfssectoren

HBO voeding

Gezondheidszorg

Andere bedrijfssectoren

HBO radiologie

Gezondheidszorg

81

Andere bedrijfssectoren

HBO accountancy en bedrijfseconomie

Zakelijke dienstverlening

Handel

Overheid

Bankwezen

Andere bedrijfssectoren

36

11

11

7

34

HBO commerciële economie

Handel

Zakelijke dienstverlening

Bankwezen

Andere bedrijfssectoren

HBO toerisme en recreatie

Weg- en railvervoer

Andere bedrijfssectoren

HBO recht en bestuur

Overheid

Zakelijke dienstverlening

Andere bedrijfssectoren dalend - stijgend sterk stijgend sterk dalend sterk stijgend -

constant -

constant sterk dalend -

sterk dalend -

dalend -

constant stijgend constant sterk stijgend

stijgend sterk stijgend sterk dalend

sterk dalend sterk stijgend 
HBO secretariaat

Zakelijke dienstverlening

Handel

Gezondheidszorg

Overheid

Andere bedrijfssectoren

HBO bedrijfskunde

Zakelijke dienstverlening

Handel

Gezondheidszorg

Onderwijs

Overheid

Bankwezen

Andere bedrijfssectoren

HBO communicatie en journalistiek

Grafische industrie

Andere bedrijfssectoren

HBO maatschappelijk werk en hulpverlening

\section{Gezondheidszorg}

Overheid

Onderwijs

Andere bedrijfssectoren

HBO personee/swerk

Overheid

Zakelijke dienstverlening

Gezondheidszorg

Andere bedrijfssectoren

HBO bibliotheek en documentatie

Overige kwartaire diensten

Overheid

Andere bedrijfssectoren

HBO uitvoerende en beeldende kunsten

Overige kwartaire diensten

Zakelijke dienstverlening

Onderwijs

Handel

Overheid

Andere bedrijfssectoren

HBO openbare orde en veiligheid

Overheid

Andere bedrijfssectoren

\section{wo}

wo letteren

Onderwijs

Zakelijke dienstverlening

Overige kwartaire diensten dalend

constant

constant sterk dalend

-

constant constant dalend stijgend dalend dalend

sterk stijgend

constant constant dalend -

sterk dalend sterk stijgend sterk stijgend

dalend sterk stijgend

dalend constant constant sterk stijgend stijgend

constant

dalend constant stijgend 
Tabel 3.19 (vervolg)

Belangrijkste bedrijfssectoren per opleidingstype, gemiddelde 1995-1996

Opleidingstype

Overheid

Handel

Andere bedrijfssectoren

WO theologie

Overige kwartaire diensten

Andere bedrijfssectoren

WO landbouw en milieukunde

Zakelijke dienstverlening

Overheid

Andere bedrijfssectoren

WO wiskunde en natuurwetenschappen

Onderwijs

Zakelijke dienstverlening

Overige kwartaire diensten

Overheid

Gezondheidszorg

Andere bedrijfssectoren

WO bouwkunde

Zakelijke dienstverlening

Andere bedrijfssectoren

WO civiele techniek

Zakelijke dienstverlening

Andere bedrijfssectoren

WO werktuigbouwkunde

Zakelijke dienstverlening

Andere bedrijfssectoren

WO elektrotechniek

Elektrotechniek

Andere bedrijfssectoren

WO informatica en bestuurlijke informatiekunde

Zakelijke dienstverlening

Andere bedrijfssectoren

WO (dier)geneeskunde

Gezondheidszorg

Andere bedrijfssectoren

WO tandheelkunde

Gezondheidszorg

Andere bedrijfssectoren

WO farmacie

Handel

Andere bedrijfssectoren
$\%$

10

trend

1994-'96

sterk stijgend

sterk stijgend

21

62

38

26

23 constant

constant

constant

stijgend

dalend

sterk stijgend sterk stijgend

dalend

constant

sterk stijgend

constant

sterk stijgend -

-

dalend 
Tabel 3.19 (vervolg)

Belangrijkste bedrijfssectoren per opleidingstype, gemiddelde 1995-1996

Opleidingstype

$\%$

trend

1994-'96

WO econom(etr)ie

Zakelijke dienstverlening

Overheid

Bankwezen

Onderwijs

Handel

Andere bedrijfssectoren

constant

dalend

stijgend

sterk dalend

sterk stijgend

WO bedrijfskunde

Zakelijke dienstverlening

Andere bedrijfssectoren

stijgend

WO accountancy en belastingen

Zakelijke dienstverlening

Overheid

-

Andere bedrijfssectoren

constant

dalend

WO rechten en bestuurskunde

Zakelijke dienstverlening

erheid

7

Onderwijs

Bankwezen

Verzekeringswezen

Andere bedriifssectoren

WO sociale wetenschappen

Gezondheidszorg

Onderwijs

Zakelijke dienstverlening

Overige kwartaire diensten

Andere bedrijfssectoren

Wo kunstwetenschappen

Diverse bedrijfssectoren 
Tabel 3.20

Uitwijkmogelijkheden naar verschillende bedrijfssectoren per opleidingstype, gemiddeld 1995-1996

Opleidingstype

spreidingsindex

typering

\section{BASISONDERWIJS}

Basisonderwijs

19,28

erg hoog

MAVO, VBO

MAVO

MAVO

18,07

erg hoog

VBO Landbouw en natuurlijke omgeving

VBO landbouw en natuurlijke omgeving

gemiddeld

VBO Techniek

VBO bouwtechniek

5,32

VBO installatietechniek

3,68

VBO mechanische techniek

15,82

VBO fijnmechanische techniek

15,55

VBO motorvoertuigentechniek

10,26

VBO elektrotechniek

VBO grafische techniek

10,86

VBO brood en banket

3,24

VBO horeca en levensmiddelentechniek

7,22

9,33

VBO vervoer

4,50

VBO Economie

VBO administratie, handel en textiel

12,76

hoog

VBO Verzorging

VBO verzorging

9,83

hoog

$\checkmark B O$ Openbare orde en veiligheid

VBO beveiliging

gemiddeld

gemiddeld

hoog

hoog

hoog

hoog

laag

gemiddeld

gemiddeld

gemiddeld

HAVO/VWO, MBO/LLW

\section{HAVONWO \\ HAVONWO}

17,71

erg hoog

MBO/LLW Landbouw en natuurlijke omgeving

MBO/LLW landbouw en veeteelt

MBO/LLW milieu en groene ruimte

laag

gemiddeld

MBO/LLW Techniek

MBO/LLW laboratorium

MBO/LLW bouw

MBO/LLW grond-, weg-en waterbouw

gemiddeld

$\mathrm{MBO} / \mathrm{LLW}$ installatietechniek

$\mathrm{MBO} / \mathrm{LLW}$ werktuigbouw en mechanische techniek

4,51

laag

2,43

14,99

MBO/LLW fijnmechanische techniek

15,41

MBO/LLW motorvoertuigentechniek

MBO/LLW vliegtuigtechniek

MBO/LLW operationele techniek

MBO/LLW elektrotechniek 


\begin{tabular}{ll} 
Opleidingstype & spreidingsindex \\
\hline
\end{tabular}

MBO/LLW levensmiddelentechniek/vleesverwerking MBO/LLW vervoer

MBO/LLW Dienstverlening en gezondheidszorg MBO dokters-, tandarts- en dierenartsassistent MBO/LLW apothekersassistent MBO/LLW verpleging MBO/LLW gezondheidstechniek MBO sociaal-cultureel $\mathrm{MBO} / \mathrm{LLW}$ verzorging MBO/LLW uiterlijke verzorging MBO/LLW horeca MBO/LLW beweging en therapie

\section{MBO/LLW Economie}

$\mathrm{MBO} / L L W$ administratie

$\mathrm{MBO} / \mathrm{LLW}$ handel

MBO/LLW secretariaat

$\mathrm{MBO} / L L W$ toerisme en recreatie

MBO/LLWW bedrijfskunde

MBO/LLW automatisering

MBO/LLW geld, bank en belastingen

MBO verzekeringswezen

MBO openbare orde en veiligheid

MBO openbare orde en veiligheid

\section{HBO}

HBO Onderwijs en tolk en vertaler $\mathrm{HBO}$ lerarenopleiding basisonderwijs

$\mathrm{HBO}$ lerarenopleiding talen

HBO lerarenopleiding natuur en techniek

$\mathrm{HBO}$ lerarenopleiding lichamelijke opvoeding

$\mathrm{HBO}$ lerarenopleiding medisch en verzorging

HBO lerarenopleiding expressie

$\mathrm{HBO}$ tolk en vertaler

\section{HBO Landbouw}

$\mathrm{HBO}$ landbouw en veeteelt

$\mathrm{HBO}$ milieukunde en levensmiddelentechnologie
$\mathrm{HBO}$ lerarenopleiding economie en maatschappij
3,74

10,12

1,89

2,24

1,30

2,92

3,91

2,31

4,03

4,94

2,88

15,53

6,30

11,86

8,06

19,26

17,81

2,95

4,31

2,41

erg laag

hoog

hoog hoog erg hoog erg hoog laag gemiddeld

erg laag
erg laag
erg laag
laag
gemiddeld
erg laag
gemiddeld
gemiddeld
laag
gemiddeld gemiddeld gemiddeld

gemiddeld gemiddeld

gemiddeld gemiddeld gemiddeld hoog erg hoog gemiddeld gemiddeld hoog

HBO Paramedisch $H B O$ verpleegkunde HBO (fysio)therapie 
Tabel 3.20 (vervolg)

Uitwijkmogelijkheden naar verschillende bedrijfssectoren per opleidingstype, gemiddeld 1995-1996

Opleidingstype

$\mathrm{HBO}$ voeding

$\mathrm{HBO}$ radiologie

HBO Economie

HBO accountancy en bedriffseconomie

HBO commerciële economie

$\mathrm{HBO}$ toerisme en recreatie

HBO recht en bestuur

HBO secretariaat

$\mathrm{HBO}$ bedrijfskunde

HBO Sociaal-cultureel

HBO communicatie en journalistiek

HBO maatschappelijk werk en hulpverlening

HBO personeelswerk

HBO bibliotheek en documentatie

HBO Kunst

$\mathrm{HBO}$ uitvoerende en beeldende kunsten

HBO Openbare orde en veiligheid

$\mathrm{HBO}$ openbare orde en veiligheid

WO

WO Letteren en theologie

WO letteren

WO theologie

WO Landbouw en milieukunde

WO landbouw en milieukunde

WO Techniek

WO wiskunde en natuurwetenschappen

WO bouwkunde

WO civiele techniek

WO werktuigbouwkunde

WO elektrotechniek

WO informatica en bestuurijke informatiekunde

WO Medisch

WO (dier)geneeskunde

WO tandheelkunde

WO farmacie

\section{WO Economie}

WO econom(etr)ie

WO bedrijfskunde

WO accountancy en belastingen

WO rechten en bestuurskunde

WO Sociaal-cultureel

WO sociale wetenschappen

spreidingsindex

typering

3,00

1,46

7,00

12,15

9,49

3,91

13,30

18,91

8,72

2,53

8,51

5,72

5,31

2,40

erg laag

4,91

2,41

6,97

7,42

3,21

5,72

14,05

8,45

5,74

1,42

1,12

4,33

10,18

11,45

2,73

5,07

5,94 laag

erg laag

gemiddeld

hoog

gemiddeld

gemiddeld

hoog

erg hoog

gemiddeld

laag

gemiddeld

gemiddeld

gemiddeld

gemiddeld

erg laag

gemiddeld

gemiddeld

laag

gemiddeld

hoog

gemiddeld

gemiddeld

erg laag

erg laag

gemiddeld

hoog

hoog

laag

gemiddeld

gemiddeld 
$\mathrm{brond}$

\section{Toellohting.}

De indicator voor uitwijkmogelijkheden geeft aan in welke mate arbeidskrachten met een bepaalde opleiding terecht kunnen komen in andere bedrijfssectoren. Deze maatstaf geeft daarmee aan in hoeverre arbeidskrachten afhankelijk zijn van de arbeidsmarktsituatie in een bepaalde bedrijfssector. De uitwijkmogelijkheden worden bepaald met behulp van de Gini-Hirschman-spreidingsindex. Deze indicator kan geïnterpreteerd worden als genormeerd aantal bedrijfssectoren waarin mensen met dit opleidingstype werkzaam zijn. 
Tabel 3.21

Overzicht opleidingstypen waarvan op de markt sterke concurrentie wordt ondervonden, gemiddelde 19951996

\section{BASISONDERWIJS}

$\begin{array}{ll}\text { Basisonderwijs } & \\ \text { VBO administratie, handel en textiel } & 0,69 \\ \text { MAVO } & 0,67 \\ \text { VBO bouwtechniek } & 0,55 \\ \text { VBO mechanische techniek } & 0,54 \\ \text { VBO motorvoertuigentechniek } & 0,52 \\ \text { VBO horeca en levensmiddelentechniek } & 0,51 \\ \text { VBO verzorging } & 0,50 \\ \text { VBO landbouw en natuurlijke omgeving } & 0,42 \\ \text { VBO vervoer } & 0,41\end{array}$

\section{MAVO, VBO}

MAVO

$\begin{array}{ll}\text { VBO administratie, handel en textiel } & 0,80\end{array}$

$\begin{array}{ll}\text { HAVOMWO } & 0,70\end{array}$

$\begin{array}{lr}\text { Basisonderwijs } & 0,67\end{array}$

MBO/LLW administratie $\quad 0,52$

$\begin{array}{lc}\text { VBO verzorging } & 0,46\end{array}$

$\begin{array}{lr}\mathrm{MBO} / L L W \text { handel } & 0,46\end{array}$

VBO landbouw en natuurlijke omgeving

MBO/LLW landbouw en veeteelt

MBO/LLW milieu en groene ruimte

VBO bouwtechniek

$\begin{array}{ll}\text { VBO installatietechniek } & 0,57\end{array}$

Basisonderwijs $\quad 0,55$

MBO/LLW bouw $\quad 0,53$

$\begin{array}{lr}\text { VBO motorvoertuigentechniek } & 0,42\end{array}$

$\begin{array}{ll}\text { VBO mechanische techniek } & 0,41\end{array}$

VBO installatietechniek

$\begin{array}{lr}\text { MBO/LLW installatietechniek } & 0,85\end{array}$

MBO/LLW bouw $\quad 0,83$

$\begin{array}{lr}\text { VBO bouwtechniek } & 0,57\end{array}$

VBO mechanische techniek

$\begin{array}{ll}\text { VBO motorvoertuigentechniek } & 0,68\end{array}$

$\begin{array}{ll}\text { VBO fijnmechanische techniek } & 0,63\end{array}$

$\begin{array}{ll}\text { Basisonderwijs } & 0,54\end{array}$

MBO/LLW werktuigbouw en mechanische techniek $\quad 0,54$

$\begin{array}{ll}\text { MBO/LLW motorvoertuigentechniek } & 0,48\end{array}$

$\begin{array}{ll}\text { VBO bouwtechniek } & 0,41\end{array}$

VBO fijnmechanische techniek $\begin{array}{ll}\text { MBO/LLW fijnmechanische techniek } & 0,78\end{array}$

MBO/LLW werktuigbouw en mechanische techniek $\quad 0,75$

$\begin{array}{ll}\mathrm{MBO} / \mathrm{LLW} \text { vliegtuigtechniek } & 0,63\end{array}$

$\begin{array}{ll}\text { VBO mechanische techniek } & 0,63\end{array}$

$\begin{array}{lr}\text { VBO motorvoertuigentechniek } & 0,44\end{array}$ 
Tabel 3.21 (vervolg)

Overzicht opleidingstypen waarvan op de markt sterke concurrentie wordt ondervonden, gemiddelde 19951996

\begin{tabular}{|c|c|}
\hline \multicolumn{2}{|l|}{ VBO motonoertuigentechniek } \\
\hline MBO/LLW motorvoertuigentechniek & 0,84 \\
\hline VBO mechanische techniek & 0,68 \\
\hline Basisonderwijs & 0,52 \\
\hline VBO fijnmechanische techniek & 0,44 \\
\hline VBO bouwtechniek & 0,42 \\
\hline MBO/LLW werktuigbouw en mechanische techniek & 0,41 \\
\hline \multicolumn{2}{|l|}{ VBO elektrotechniek } \\
\hline MBO/LLW elektrotechniek & 0,63 \\
\hline \multicolumn{2}{|l|}{ VBO grafische techniek } \\
\hline MBO/LLW grafische techniek & 0,99 \\
\hline \multicolumn{2}{|l|}{ VBO brood en banket } \\
\hline MBO/LLW levensmiddelentechniek/vleesverwerking & 0,72 \\
\hline MBO/LLW brood en banket & 0,64 \\
\hline MBO/LLW procestechniek & 0,49 \\
\hline VBO horeca en levensmiddelentechniek & 0,42 \\
\hline \multicolumn{2}{|l|}{ VBO horeca en levensmiddelentechniek } \\
\hline MBO/LLW horeca & 0,65 \\
\hline Basisonderwijs & 0,51 \\
\hline VBO brood en banket & 0,42 \\
\hline \multicolumn{2}{|l|}{ VBO vervoer } \\
\hline Basisonderwijs & 0,41 \\
\hline \multicolumn{2}{|l|}{ VBO administratie, handel en textiel } \\
\hline MAVO & 0,80 \\
\hline Basisonderwijs & 0,69 \\
\hline HAVONWO & 0,55 \\
\hline MBO/LLW handel & 0,55 \\
\hline VBO verzorging & 0,48 \\
\hline MBO/LLW administratie & 0,44 \\
\hline \multicolumn{2}{|l|}{ VBO verzorging } \\
\hline Basisonderwijs & 0,50 \\
\hline VBO administratie, handel en textiel & 0,48 \\
\hline MAVO & 0,46 \\
\hline
\end{tabular}

VBO beveiliging

\section{HAVOIVWO, MBO/LLW}

\section{HAVONWO}

MBO/LLW administratie $\quad 0,71$

$\begin{array}{ll}\text { MAVO } & 0,70\end{array}$

VBO administratie, handel en textiel $\quad 0,55$

$\begin{array}{ll}\mathrm{HBO} \text { toerisme en recreatie } & 0,47\end{array}$

$\begin{array}{ll}\text { MBO/LLW toerisme en recreatie } & 0,45\end{array}$

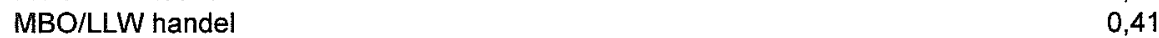

$M B O / L L W$ landbouw en veeteelt

$\begin{array}{lc}\text { VBO landbouw en natuurlijke omgeving } & 0,86\end{array}$ 
Tabe/ 3.21 (vervolg)

Overzicht opleidingstypen waarvan op de markt sterke concurrentie wordt ondervonden, gemiddelde 19951996

MBO/LLW milieu en groene ruimte MBO/LLW landbouw en veeteelt

MBO/LLW laboratorium

MBO/LLW bouW

$\mathrm{MBO} / L L W$ installatietechniek

VBO installatietechniek

VBO bouwtechniek

0,53

$\mathrm{HBO}$ bouwkunde

MBO/LLW grond-, weg- en waterbouw

MBO/LLW operationele techniek

HBO civiele techniek

MBO/LLW installatietechniek

MBO/LLW bouw

VBO installatietechniek

MBO/LLW werktuigbouw en mechanische techniek

MBO/LLW fijnmechanische techniek

MBO/LLW vliegtuigtechniek

0,76

VBO fijnmechanische techniek

0,75

VBO mechanische techniek

0,54

MBO/LLW motorvoertuigentechniek

0,45

VBO motorvoertuigentechniek

MBO/LLW fijnmechanische techniek

MBO/LLW werktuigbouw en mechanische techniek $\quad 0,81$

VBO fijnmechanische techniek

MBO/LLW vliegtuigtechniek

MBO/LLW motorvoertuigentechniek

VBO motorvoertuigentechniek

MBO/LLW vliegtuigtechniek

VBO mechanische techniek

MBO/LLW werktuigbouw en mechanische techniek

MBO/LLW vliegtuigtechniek

MBO/LLW werktuigbouw en mechanische techniek $\quad 0,76$

$\mathrm{MBO} / \mathrm{LLW}$ fijnmechanische techniek

0,72

VBO fijnmechanische techniek

0,63

MBO/LLW motorvoertuigentechniek

0,56

MBO/LLW operationele techniek

MBO/LLW grond-, weg- en waterbouw

MBO/LLW elektrotechniek

VBO elektrotechniek '

MBO/LLW grafische techniek

VBO grafische techniek 
Tabel 3.21 (vervolg)

Overzicht opleidingstypen waarvan op de markt sterke concurrentie wordt ondervonden, gemiddelde 19951996

MBO/LLW procestechniek

VBO brood en banket

MBO/LLW brood en banket

MBO/LLW levensmiddelentechniek/vleesverwerking

VBO brood en banket

MBO/LLW levensmiddelentechniek/vleesverwerking

MBO/LLW brood en banket

VBO brood en banket

$M B O / L L W$ vervoer

MBO dokters-, tandarts- en dierenartsassistent $\mathrm{MBO} / \mathrm{LLW}$ verpleging

MBO/LLW apothekersassistent $\mathrm{MBO} / \mathrm{LLW}$ gezondheidstechniek

$M B O / L L W$ verpleging

MBO dokters-, tandarts- en dierenartsassistent

MBO/LLW gezondheidstechniek

MBO/LLW apothekersassistent

MBO sociaal-cultureel

$M B O / L L W$ verzorging

$M B O / L L W$ uiterlijke verzorging

$M B O / L L W$ horeca

VBO horeca en levensmiddelentechniek

MBO/LLW beweging en therapie

$\begin{array}{lr}\text { MBO/LLW administratie } & 0,71 \\ \text { HAVO/WO } & 0,52 \\ \text { MBO verzekeringswezen } & 0,52 \\ \text { MAVO } & 0,51 \\ \text { HBO secretariaat } & 0,48 \\ \text { HBO accountancy en bedrijfseconomie } & 0,44 \\ \text { VBO administratie, handel en textiel } & \\ \text { MBO/LLW handel } & 0,55 \\ \text { VBO administratie, handel en textiel } & 0,46 \\ \text { MAVO } & 0,41 \\ \text { HAVOMWO } & \end{array}$

MBO/LLW secretariaat

$M B O / L L W$ toerisme en recreatie

$\mathrm{HBO}$ toerisme en recreatie 
Tabe/ 3.21 (vervolg)

Overzicht opleidingstypen waarvan op de markt sterke concurrentie wordt ondervonden, gemiddelde 19951996

MBO/LLW bedrijfskunde

HBO bedrijfskunde

MBO/LLW automatisering

MBO/LLW geld, bank en belastingen

$M B O$ verzekeringswezen

MBO/LLW administratie

MBO openbare orde en veiligheid

HBO

HBO lerarenopleiding basisondenwijs

HBO lerarenopleiding talen HBO lerarenopleiding expressie

HBO lerarenopleiding natuur en techniek

$\mathrm{HBO}$ lerarenopleiding medisch en verzorging

HBO lerarenopleiding economie en maatschappij

HBO lerarenopleiding lichamelijke opvoeding

HBO lerarenopleiding medisch en verzorging HBO lerarenopleiding natuur en techniek

HBO lerarenopleiding expressie

$\mathrm{HBO}$ lerarenopleiding talen

HBO tolk en vertaler

WO letteren

HBO landbouw en veeteelt

HBO milieukunde en levensmiddelentechnologie

HBO milieukunde en levensmiddelentechnologie

HBO landbouw en veeteelt

HBO laboratorium

$\mathrm{HBO}$ radiologie

HBO bouwkunde

MBO/LLW bouw

HBO civiele techniek

$\begin{array}{ll}\text { MBO/LLW grond-, weg- en waterbouw } & 0,54\end{array}$

Hbo werktuigbouwkunde

$\mathrm{HBO}$ bedriffskunde

HBO elektrotechniek

$\mathrm{HBO}$ informatica 
Tabel 3.21 (vervolg)

Overzicht opleidingstypen waarvan op de markt sterke concurrentie wordt ondervonden, gemiddelde 19951996

HBO informatica

HBO elektrotechniek

HBO chemische technologie

HBO vervoer en logistiek

$H B O$ verpleegkunde

HBO (fysio)therapie

$\mathrm{HBO}$ voeding

HBO (fysio) therapie

$H B O$ voeding

$H B O$ verpleegkunde

$H B O$ voeding

HBO (fysio)therapie

$\mathrm{HBO}$ verpleegkunde

HBO radiologie

$\mathrm{HBO}$ laboratorium

HBO accountancy en bedrijfseconomie

WO accountancy en belastingen

HBO secretariaat

0,51

MBO/LLW administratie

0,48

$\mathrm{HBO}$ recht en bestuur

HBO commerciële economie

HBO bedrijfskunde

HBO toerisme en recreatie

$\begin{array}{ll}\mathrm{MBO} / \mathrm{LLW} \text { toerisme en recreatie } & 0,96\end{array}$

$\begin{array}{ll}\text { HBO secretariaat } & 0,48\end{array}$

$\begin{array}{ll}\text { HAVONWWO } & 0,47\end{array}$

HBO recht en bestuur

$\begin{array}{ll}\mathrm{HBO} \text { accountancy en bedrijfseconomie } & 0,40\end{array}$

HBO secretariaat

$\mathrm{MBO} / \mathrm{LLW}$ administratie

HBO accountancy en bedrijfseconomie

$\mathrm{HBO}$ toerisme en recreatie

HBO bedrijfskunde

$\begin{array}{ll}\text { HBO commerciële economie } & 0,67\end{array}$

$\begin{array}{ll}\mathrm{HBO} \text { werktuigbouwkunde } & 0,53\end{array}$

$\begin{array}{ll}\mathrm{MBO} / L L W \text { bedrijfskunde } & 0,46\end{array}$

HBO communicatie en journalistiek

HBO maatschappelijk werk en hulpverlening

$\mathrm{HBO}$ personeelswerk 
Tabel 3.21(vervolg)

Overzicht opleidingstypen waarvan op de markt sterke concurrentie wordt ondervonden, gemiddelde 1995-1996

Opleidingstype

concurrentie-index

HBO personeelswerk

HBO maatschappelijk werk en hulpverlening

0,49

HBO bibliotheek en documentatie

HBO uitvoerende en beeldende kunsten

HBO openbare orde en veiligheid

wo

Wo letteren

WO kunstwetenschappen

0,55

HBO tolk en vertaler

WO theologie

WO landbouw en milieukunde

WO civiele techniek

0,46

WO wiskunde en natuurwetenschappen

WO wiskunde en natuurwetenschappen

WO landbouw en milieukunde

WO bouwkunde

WO civiele techniek

Wo civiele techniek

WO bouwkunde

WO landbouw en milieukunde

WO werktuigbouwkunde

WO elektrotechniek

WO elektrotechniek

WO informatica en bestuurlijke informatiekunde $\quad 0,63$

WO werktuigbouwkunde

WO informatica en bestuunijke informatiekunde

WO elektrotechniek

WO (dier)geneeskunde

WO tandheelkunde

WO tandheelkunde

WO (dier)geneeskunde

WO farmacie

WO econom(etr)ie

WO bedrijfskunde

0,49

WO rechten en bestuurskunde

0,40

WO bedrijfskunde

WO econom(etr)ie 
Tabel 3.21 (vervolg)

Overzicht opleidingstypen waarvan op de markt sterke concurrentie wordt ondervonden, gemiddelde 19951996

Opleidingstype

concurrentie-index

WO accountancy en belastingen

$\mathrm{HBO}$ accountancy en bedrijfseconomie

0,74

WO rechten en bestuurskunde

WO econom(etr)ie

0,40

WO sociale wetenschappen

WO kunstwetenschappen

WO letteren

0,55

Bron: ROA

\section{Toelichting:}

De concurrentie-index tussen opleidingstypen geeft aan hoe sterk de beroepenstructuur van twee opleidingen op elkaar lijkt. 
Tabel 3.22

Conjunctuurgevoeligheid per opleidingstype

Opleidingstype

conjunctuurgevoeligheid

typering

\section{BASISONDERWIJS}

Basisonderwijs

gemiddeld

MAVO, VBO

MAVO

gemiddeld

VBO Landbouw en natuurlijke omgeving

VBO landbouw en natuurlijke omgeving

gemiddeld

VBO Techniek

VBO bouwtechniek

1,54

1,76

1,26

VBO installatietechniek

VBO mechanische techniek

1,23

VBO fijnmechanische techniek

1,24

VBO motorvoertuigentechniek

1,19

VBO elektrotechniek

VBO grafische techniek

1,42

VBO brood en banket

1,27

1,00

VBO horeca en levensmiddelentechniek

1,48

VBO vervoer

0,73

VBO administratie, handel en textiel

VBO Verzorging

VBO verzorging

0,60

erg hoog

erg hoog

hoog

hoog

hoog

hoog

erg hoog

hoog

gemiddeld

erg hoog

VBO Openbare orde en veiligheid

VBO beveiliging

0,64

gemiddeld

HAVO/VWO, MBO/LLW

HAVONWO

HAVONWO

gemiddeld

MBO/LLW Landbouw en natuurlike omgeving

$M B O / L L W$ landbouw en veeteelt

$\mathrm{MBO} / L L W$ milieu en groene ruimte

laag

laag

MBO/LLW Techniek

MBO/LLW laboratorium

MBO/LLW bouw

MBO/LLW grond-, weg- en waterbouw

1,52

MBO/LLW installatietechniek

MBO/LLW werktuigbouw en mechanische techniek

1,16

1,23

MBO/LLW fijnmechanische techniek

1,10

MBO/LLW motorvoertuigentechniek

1,10

MBO/LLW viegtuigtechniek

MBO/LLW operationele techniek

1,07

MBO/LLW elektrotechniek

1,13

MBO/LLW grafische techniek

1,27

MBO/LLW procestechniek

0,84

MBO/LLW brood en banket

0,40

laag erg hoog erg hoog erg hoog hoog hoog hoog hoog hoog hoog hoog gemiddeld laag 
MBO Dienstverlening en gezondheidszorg

MBO dokters-, tandarts- en dierenartsassistent

$\mathrm{MBO} / \mathrm{LLW}$ apothekersassistent

MBO/LLW verpleging

MBO/LLW gezondheidstechniek

0,43

MBO sociaal-cultureel

0,80

MBO/LLW verzorging

0,70

MBO/LLW uiterlijke verzorging

MBO/LLW horeca

MBO/LLW beweging en therapie

\author{
MBO/LLW Economie \\ MBO/LLW administratie \\ $\mathrm{MBO} / \mathrm{LLW}$ handel \\ MBO/LLW secretariaat \\ MBO/LLW toerisme en recreatie \\ MBO/LLW bedrijfskunde \\ MBO/LLW automatisering \\ $M B O$ verzekeringswezen
}

0,83

MBO Openbare orde en veiligheid

MBO openbare orde en veiligheid

\title{
HBO
}

HBO Onderwijs en tolk en vertaler

$\mathrm{HBO}$ lerarenopleiding basisonderwijs

HBO lerarenopleiding natuur en techniek

HBO lerarenopleiding economie en maatschappij

HBO lerarenopleiding lichamelijke opvoeding

$\mathrm{HBO}$ lerarenopleiding medisch en verzorging

\section{HBO Landbouw}

HBO landbouw en veeteelt

HBO milieukunde en levensmiddelentechnologie

\section{HBO Techniek}

$\mathrm{HBO}$ laboratorium

HBO bouwkunde

HBO civiele techniek

$\mathrm{HBO}$ werktuigbouwkunde

HBO elektrotechniek

$\mathrm{HBO}$ informatica

HBO chemische technologie 


\section{HBO voeding}

$\mathrm{HBO}$ radiologie

\section{HBO Economie}

HBO accountancy en bedrijfseconomie

HBO commerciële economie

$\mathrm{HBO}$ toerisme en recreatie

$\mathrm{HBO}$ recht en bestuur

HBO secretariaat

HBO bedrijfskunde

HBO Sociaal-cultureel

HBO communicatie en journalistiek

HBO maatschappelijk werk en hulpverlening

HBO personeelswerk

HBO bibliotheek en documentatie

HBO Kunst

HBO uitvoerende en beeldende kunsten

HBO Openbare orde en veiligheid

HBO openbare orde en veiligheid

wo

WO Letteren en theologie

WO letteren

WO theologie

WO Landbouw en milieukunde

WO landbouw en milieukunde

WO Techniek

WO wiskunde en natuurwetenschappen

WO bouwkunde

WO civiele techniek

WO werktuigbouwkunde

WO elektrotechniek

WO informatica en bestuurlijke informatiekunde

WO Medisch

WO (dier)geneeskunde

WO tandheelkunde

WO farmacie

WO Economie

WO econom(etr)ie

WO bedrijfskunde

WO accountancy en belastingen
0,49

0,15

laag

0,96

0,74

0,82

0,35

0,60

0,65

gemiddeld

erg laag

erg laag

hoog

hoog

gemiddeld

gemiddeld gemiddeld

hoog

gemiddeld gemiddeld gemiddeld erg laag

laag

erg laag

laag

0,63

gemiddeld

gemiddeld gemiddeld erg hoog erg hoog hoog

erg laag

0,12

0,78

erg laag

gemiddeld

0,86

0,81

0,65

0,60

gemiddeld gemiddeld gemiddeld laag

0,54 laag

\section{WO Sociaal-cultureel}

WO sociale wetenschappen 
Tabel 3.22 (vervolg)

Conjunctuurgevoeligheid per opleidingstype

Opleidingstype

conjunctuurgevoeligheid

typering

WO Kunst

WO kunstwetenschappen

0,43

laag

\section{Bron: ROA}

Toelichting:

De conjunctuurgevoeligheid van de werkgelegenheid heeft betrekking op de mate waarin de werkgelegenheid van de beroepsgroepen waarin mensen met een bepaalde opleidingsachtergrond werkzaam zijn, gevoelig is voor veranderingen van de economische situatie. Deze indicator geeft daarmee de mate van werkzekerheid aan voor dat opleidingstype. 


\section{BASISONDERWIJS}

MAVO, VBO

MAVO

VBO Landbouw en natuurlijke omgeving

VBO landbouw en natuurlijke omgeving

VBO Techniek

VBO bouwtechniek

VBO installatietechniek

VBO mechanische techniek

VBO fijnmechanische techniek

VBO motorvoertuigentechniek

VBO elektrotechniek

VBO grafische techniek

VBO brood en banket

VBO horeca en levensmiddelentechniek

VBO vervoer

29.300

7

1,4 gemiddeld

$-12.700$

-3 ,

erg laag

3.800

$-100$

$-11.100$

400

$-4.700$

2.100

$-1.000$

$-1.700$

$-2.000$

$-3.000$

$-15.300$

$-13$

$-1.800$

$-1$

4.000

34

VBO beveiliging
VBO Openbare or

HAVONWO, MBO/LLW

\section{HAVONWO \\ HAVOMWO}

70.900

22

17.600

5.800

\section{6}

25

$\mathrm{MBO} / L L W$ milieu en groene ruimte

MBO/LLW Techniek

$\mathrm{MBO} / \mathrm{LLW}$ laboratorium

3.800

32.300

3.500

MBO/LLW grond-, weg- en waterbouw

$\mathrm{MBO} / \mathrm{LLW}$ installatietechniek

4.000

MBO/LLW werktuigbouw en mechanische techniek

12.400

900

$\mathrm{MBO} / \mathrm{LLW}$ fijnmechanische techniek

MBO/LLW motorvoertuigentechniek

13.200

MBO/LLW vliegtuigtechniek

MBO/LLW operationele techniek

MBO/LLW elektrotechniek

MBO/LLW grafische techniek

MBO/LLW procestechniek
$4,1 \quad$ gemiddeld

3,0

4,5

gemiddeld

hoog

$\begin{aligned} 3,8 & \text { gemiddeld } \\ 4,4 & \text { hoog } \\ 2,7 & \text { gemiddeld } \\ 3,1 & \text { gemiddeld } \\ 1,7 & \text { gemiddeld } \\ 1,2 & \text { laag } \\ 3,5 & \text { gemiddeld } \\ -2,0 & \text { laag } \\ 4,9 & \text { hoog } \\ 2,8 & \text { gemiddeld } \\ 0,3 & \text { laag } \\ 4,9 & \text { hoog }\end{aligned}$


Tabe/ 3.23 (vervolg)

Verwachte uitbreidingsvraag per opleidingstype, 1997-2002

$\begin{array}{llll}\text { Opleidingstype } & \text { aantal } & \begin{array}{l}\text { total } \\ \%\end{array} & \begin{array}{c}\text { gemiddeld } \\ \text { jaarlijks } \%\end{array}\end{array}$ typering

MBO/LLW brood en banket
MBO/LLW levensmiddelentechniek/vleesverwerking
MBO/LLW vervoer

$-400$

4.900

11.300

$M B O / L L W$ Dienstverlening en verzorging

MBO dokters-, tandarts- en dierenartsassistent

MBO/LLW apothekersassistent

$\mathrm{MBO} / \mathrm{LLW}$ verpleging

MBO sociaal-cultureel

MBO/LLW verzorging

$\mathrm{MBO} / L L W$ uiterlijke verzorging

MBO/LLW horeca

$\mathrm{MBO} / L L W$ beweging en therapie

MBO/LLW Economie

MBO/LLW administratie

MBO/LLW handel

$\mathrm{MBO} / L L W$ secretariaat

$\mathrm{MBO} / \mathrm{LLW}$ toerisme en recreatie

MBO Openbare orde en veiligheid

MBO openbare orde en veiligheid

\section{HBO}

HBO Onderwijs en tolk en vertaler

$\mathrm{HBO}$ lerarenopleiding basisonderwijs

$\mathrm{HBO}$ lerarenopleiding talen

HBO lerarenopleiding natuur en techniek

HBO lerarenopleiding economie en maatschappij

HBO lerarenopleiding lichamelijke opvoeding

$\mathrm{HBO}$ lerarenopleiding medisch en verzorging

HBO lerarenopleiding expressie

$\mathrm{HBO}$ tolk en vertaler

$\begin{array}{rr}3.300 & 15 \\ 4.800 & 28 \\ 24.000 & 20 \\ 16.200 & 27 \\ 6.600 & 4 \\ 12.700 & 21 \\ 20.600 & 27 \\ 4.200 & 16\end{array}$

44.700

20.700

23.400

4.400

3.900

4

16

7

23

24

19.500

$-3.200$

2.100

6.000

100

200

800

1.900

2.900

2.000

HBO Landbouw
HBO landbouw en veeteelt
HBO milieukunde en levensmiddelentechnologie

HBO Techniek

HBO laboratorium

HBO bouwkunde

HBO civiele techniek

HBO werktuigbouwkunde

$\mathrm{HBO}$ elektrotechniek

$\mathrm{HBO}$ informatica

$\mathrm{HBO}$ chemische technologie

HBO vervoer en logistiek

HBO Paramedisch

$\mathrm{HBO}$ verpleegkunde

HBO (fysio)therapie

$\mathrm{HBO}$ voeding

$\begin{array}{rr}400 & 1 \\ 3.900 & 20 \\ 1.700 & 10 \\ 5.400 & 15 \\ 5.100 & 12 \\ 10.200 & 28 \\ 1.400 & 17 \\ 2.800 & 12 \\ & \\ 11.800 & 23 \\ 9.300 & 24 \\ 1.000 & 21\end{array}$

12

$-11$

6

16

0

1

3

20

35

14

1

20

10

12

28

17

12 $\begin{aligned}-0,6 & \text { laag } \\ 3,9 & \text { gemiddeld } \\ 3,9 & \text { gemiddeld }\end{aligned}$

2,9 gemiddeld

5,1 hoog

3,7 gemiddeld

4,9 hoog

0,7 laag

3,9 gemiddeld

5,0 hoog

3,0 gemiddeld

$3,0 \quad$ gemiddeld

1,4 gemiddeld

4,2 gemiddeld

4,5 hoog

$0,8 \quad$ laag

2,3 gemiddeld

$-2,2$ erg laag

1,1 laag

3,1 gemiddeld

$0,1 \quad$ laag

0,2 laag

0,5 laag

3,7 gemiddeld

6,1 erg hoog

2,6 gemiddeld

0,2 laag

3,7 gemiddeld

1,9 gemiddeld

2,8 gemiddeld

2,4 gemiddeld

5,0 hoog

3,2 gemiddeld

2,3 gemiddeld

4,1 gemiddeld

4,5 hoog

3,9 gemiddeld 
Tabe/ 3.23 (vervolg)

Verwachte uitbreidingsvraag per opleidingstype, 1997-2002

Opleidingstype

aantal

totaal

gemiddeld

typering

$\% \quad$ jaarlijks \%

\section{HBO Economie}

HBO accountancy en bedrijfseconomie $\quad 8.400$

HBO commerciële economie

12.000

15

2300

29

HBO toerisme en recreatie

6.900

25

HBO recht en bestuur

4.600

$\mathrm{HBO}$ secretariaat

16.000

32

15

HBO bedrijfskunde

25

2,7 gemiddeld

5,2 hoog

4,6 hoog

5,6 hoog

2,8 gemiddeld

HBO Sociaal-cultureel

HBO communicatie en journalistiek

5.300

32

9.600

13

HBO maatschappelijk werk en hulpverlening

9.600

$-1$

HBO bibliotheek en documentatie

3.300

24

4,5 hoog

HBO Kunst

HBO uitvoerende en beeldende kunsten

8.200

600

6

5,8 hoog

2,5 gemiddeld

$-0,2$ laag

4,4 hoog

HBO Openbare orde en veiligheid

HBO openbare orde en veiligheid

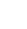

wo

WO Letteren en theologie

wo letteren

WO theologie

11.100

25

$-900$

$-15$

4,5 hoog

WO Landbouw en milieukunde

WO landbouw en milieukunde

1.800

15

$-3,2$

erg laag

WO Techniek

WO wiskunde en natuurwetenschappen

6.100

10

3.000

32

WO civiele techniek

1.600

23

WO werktuigbouwkunde

1.300

13

WO elektrotechniek

1.400

15

WO informatica en bestuurlijke informatiekunde

4.700

60

3,3 gemiddeld

1,2 laag

WO Medisch

WO (dier)geneeskunde

WO tandheelkunde

WO farmacie

800

700

$-200$

2
11
-2

WO Economie

WO econom(etr)ie

15.900

10.300

38

49

WO accountancy en belastingen

6.700

36

WO rechten en bestuurskunde

7.000

12

2,9 gemiddeld

1,9 gemiddeld

5,7 hoog

4,2 gemiddeld

2,5 gemiddeld

2,9 gemiddeld

9,8 erg hoog

WO Sociaal-cultureel

WO sociale wetenschappen

19.000

23

$\begin{aligned} 0,4 & \text { laag } \\ 2,1 & \text { gemiddeld } \\ -0,5 & \text { laag }\end{aligned}$

$\begin{array}{ll}6,6 & \text { erg hoog } \\ 8,3 & \text { erg hoog } \\ 6,4 & \text { erg hoog } \\ 2,3 & \text { gemiddeld }\end{array}$

$4,2 \quad$ gemiddeld 
Tabel 3.23 (vervolg)

Verwachte uitbreidingsvraag per opleidingstype, 1997-2002

$\begin{array}{llll}\text { Opleidingstype } & \text { aantal } & \begin{array}{l}\text { totaal } \\ \%\end{array} & \begin{array}{c}\text { gemiddeld } \\ \text { jaarlijks } \%\end{array}\end{array}$ typering

\section{WO Kunst}

WO kunstwetenschappen

$900 \quad 18$

18

$3,4 \quad$ gemiddeld

Totaal

560.800

9

1,7 gemiddeld

\section{Bron: ROA}

\section{Toelichting:}

Uitbreidingsvraag is de vraag naar nieuwe arbeidskrachten die ontstaat door groei van de werkgelegenheid. Als er sprake is van een werkgelegenheidsdaling, is de uitbreidingsvraag negatief. 


\section{BASISONDERWIJS}

\section{Basisonderwijs}

MAVO, VBO

MAVO
MAVO

VBO Landbouw en natuurlijke omgeving

VBO landbouw en natuurlijke omgeving

VBO Techniek

VBO bouwtechniek

VBO installatietechniek

VBO mechanische techniek

VBO fijnmechanische techniek

VBO motorvoertuigentechniek

VBO elektrotechniek

VBO grafische techniek

VBO brood en banket

VBO horeca en levensmiddelentechniek

VBO vervoer

\section{VBO Economie}

VBO administratie, handel en textiel

122.500

15.200

26.900

2.900

30.600

1.000

8.400

15.300

1.900

2.500

8.200

8.700

23.200

19

51.900

29

VBO verzorging

VBO Openbare orde en veiligheid

VBO beveiliging

1.000

\section{HAVONWO, MBO/LLW}

\section{HAVONWO}

HAVONWO

MBO/LLW Landbouw en natuurlijke omgeving

$\mathrm{MBO} / \mathrm{LLW}$ landbouw en veeteelt

$\mathrm{MBO} / L L W$ milieu en groene ruimte

MBO/LLW Techniek

MBO/LLW laboratorium

MBO/LLW bouw

MBO/LLW grond-, weg- en waterbouw'

$\mathrm{MBO} / \mathrm{LLW}$ installatietechniek

MBO/LLW werktuigbouw en mechanische techniek

MBO/LLW fijnmechanische techniek

MBO/LLW motorvoertuigentechniek

MBO/LLW vliegtuigtechniek

MBO/LLW operationele techniek

MBO/LLW elektrotechniek

MBO/LLW grafische techniek

MBO/LLW procestechniek
72.700

23

20.200

3.100

5.200

26.500

5.300

4.000

31.400

2.800

13.900

1.700

1.200

25.900

6.800

3.400
23

4,3 hoog
5,4 erg hoog

3,8 gemiddeld

3,7 gemiddeld

5,2 erg hoog

4,8 erg hoog

3,5 gemiddeld

3,8 gemiddeld

4,4 hoog

5,8 erg hoog

3,7 gemiddeld

5,0 erg hoog

4,3 hoog

3,6 gemiddeld

5,2 erg hoog

9

1,6 erg laag

4,2 hoog

$3,4 \quad$ gemiddeld

2,5 laag

$\begin{array}{ll}5,2 & \text { erg hoog } \\ 3,6 & \text { gemiddeld } \\ 4,0 & \text { gemiddeld } \\ 3,1 & \text { laag } \\ 4,1 & \text { gemiddeld } \\ 3,7 & \text { gemiddeld } \\ 3,6 & \text { gemiddeld } \\ 4,9 & \text { erg hoog } \\ 3,1 & \text { laag } \\ 3,1 & \text { laag } \\ 3,2 & \text { laag } \\ 2,6 & \text { laag }\end{array}$




\author{
MBO/LLW brood en banket \\ MBO/LLW levensmiddelentechniek/vleesverwerking \\ MBO/LLW vervoer
}

\section{MBO Dienstverlening en gezondheidszorg}

MBO dokters-, tandarts- en dierenartsassistent

$\mathrm{MBO} / \mathrm{LLW}$ apothekersassistent

$\mathrm{MBO} / \mathrm{LLW}$ verpleging

MBO sociaal-cultureel

$\mathrm{MBO} / L L W$ verzorging

MBO/LLW uiterlijke verzorging

MBO/LLW horeca

MBO/LLW beweging en therapie

\author{
$M B O / L L W$ Economie \\ MBO/LLW administratie \\ MBO/LLW handel \\ MBO/LLW secretariaat \\ $\mathrm{MBO} / \mathrm{LLW}$ toerisme en recreatie \\ MBO Openbare orde en veiligheid \\ MBO openbare orde en veiligheid
}

2.800

4.000

8.400

19

18

16

2.600

2.900

23.200

10.300

32.600

10.800

12.600

3.800

43.200

52.900

18.700

700

20.900

23

laag gemiddeld

laag

laag gemiddeld laag laag

$\begin{array}{ll}2,9 & \text { laag } \\ 3,4 & \text { gemiddeld } \\ 3,4 & \text { gemiddeld } \\ 0,8 & \text { erg laag }\end{array}$

HBO

$H B O$ Onderwijs en tolk en vertaler $\mathrm{HBO}$ lerarenopleiding basisonderwijs

HBO lerarenopleiding talen

28.200

8.300

7.200

7.200

2.500

3.200

7.500

1.000

1.900

2.600

HBO milieukunde en levensmiddelentechnologie

HBO Techniek

HBO laboratorium

HBO bouwkunde

HBO civiele techniek

$\mathrm{HBO}$ werktuigbouwkunde

HBO elektrotechniek

$\mathrm{HBO}$ informatica

$\mathrm{HBO}$ chemische technologie

$\mathrm{HBO}$ vervoer en logistiek
8.500

4.400

3.500

8.200

6.500

5.100

2.000

5.400

8.800

5.700

800

\footnotetext{
$\mathrm{HBO}$ verpleegkunde

HBO (fysio)therapie

$\mathrm{HBO}$ voeding
}

3,3

gemiddeld gemiddeld

$\begin{array}{ll}4,1 & \text { gemiddeld } \\ 4,2 & \text { hoog } \\ 3,8 & \text { gemiddeld } \\ 4,1 & \text { gemiddeld } \\ 3,0 & \text { laag } \\ 2,6 & \text { laag } \\ 4,5 & \text { hoog } \\ 4,2 & \text { hoog }\end{array}$

gemiddeld

erg hoog

gemiddeld

gemiddeld

laag

hoog

hoog

erg laag

\section{3,2 laag}

2,8 laag

3,0 laag 
Tabel 3.24 (vervolg)

Verwachte vervangingsvraag per opleidingstype, 1997-2002

Opleidingstype $\quad$ aantal $\begin{array}{r}\text { totaal } \\ \%\end{array} \underset{\text { jaarlijks } \%}{\text { gemiddeld }}$ typering

\begin{tabular}{|c|c|c|c|c|}
\hline \multicolumn{5}{|l|}{ HBO Economie } \\
\hline HBO accountancy en bedrijfseconomie & 13.600 & 23 & 4,3 & hoog \\
\hline HBO commerciële economie & 7.800 & 19 & 3,5 & gemiddeld \\
\hline HBO toerisme en recreatie & 2.300 & 25 & 4,6 & hoog \\
\hline HBO recht en bestuur & 4.400 & 20 & 3,7 & gemiddeld \\
\hline HBO secretariaat & 7.500 & 24 & 4,4 & hoog \\
\hline HBO bedrijfskunde & 13.300 & 20 & 3,8 & gemiddeld \\
\hline \multicolumn{5}{|l|}{ HBO Sociaal-cultureel } \\
\hline HBO communicatie en journalistiek & 1.700 & 10 & 2,0 & erg laag \\
\hline HBO maatschappelijk werk en hulpverlening & 13.300 & 18 & 3,3 & gemiddeld \\
\hline HBO personeelswerk & 3.300 & 17 & 3,2 & laag \\
\hline HBO bibliotheek en documentatie & 2.200 & 16 & 3,0 & laag \\
\hline \multicolumn{5}{|l|}{ HBO Kunst } \\
\hline HBO uitvoerende en beeldende kunsten & 10.700 & 23 & 4,2 & hoog \\
\hline \multicolumn{5}{|l|}{ HBO Openbare orde en veiligheid } \\
\hline HBO openbare orde en veiligheid & 2.200 & 22 & 4,0 & gemiddeld \\
\hline \multicolumn{5}{|l|}{ wo } \\
\hline \multicolumn{5}{|l|}{ WO Letteren en theologie } \\
\hline WO letteren & 9.100 & 20 & 3,7 & gemiddeld \\
\hline WO theologie & 1.500 & 27 & 4,8 & erg hoog \\
\hline \multicolumn{5}{|l|}{ WO Landbouw en milieukunde } \\
\hline WO landbouw en milieukunde & 1.300 & 10 & 2,0 & erg laag \\
\hline \multicolumn{5}{|l|}{ WO Techniek } \\
\hline WO wiskunde en natuurwetenschappen & 12.700 & 21 & 3,8 & gemiddeld \\
\hline WO bouwkunde & 1.900 & 20 & 3,8 & gemiddeld \\
\hline WO civiele techniek & 1.800 & 25 & 4,6 & hoog \\
\hline WO werktuigbouwkunde & 1.700 & 17 & 3,2 & laag \\
\hline WO elektrotechniek & 1.700 & 19 & 3,5 & gemiddeld \\
\hline WO informatica en bestuurlijke informatiekunde & 800 & 10 & 1,8 & erg laag \\
\hline \multicolumn{5}{|l|}{ WO Medisch } \\
\hline WO (dier)geneeskunde & 9.000 & 20 & 3,8 & gemiddeld \\
\hline WO tandheelkunde & 1.400 & 22 & 4,0 & gemiddeld \\
\hline WO farmacie & 900 & 13 & 2,5 & laag \\
\hline \multicolumn{5}{|l|}{ WO Economie } \\
\hline WO econom(etr)ie & 8.600 & 20 & 3,8 & gemiddeld \\
\hline WO bedrijfskunde & 3.200 & 15 & 2,9 & laag \\
\hline WO accountancy en belastingen & 3.900 & 21 & 3,9 & gemiddeld \\
\hline WO rechten en bestuurskunde & 11.400 & 20 & 3,7 & gemiddeld \\
\hline \multicolumn{5}{|l|}{ WO Sociaal-cultureel } \\
\hline WO sociale wetenschappen & 14.200 & 17 & 3,2 & laag \\
\hline
\end{tabular}


Tabe/ 3.24 (vervolg)

Verwachte vervangingsvraag per opleidingstype, 1997-2002

Opleidingstype

aantal totaal gemiddeld

typering

$\%$ jaarlijks \%

\section{WO Kunst}

WO kunstwetenschappen

700

15

2,9

laag

Totaal

1.264 .400

20

3,7 gemiddeld

Bron: ROA

Toelichting:

De vraag naar nieuwe arbeidskrachten die ontstaat doordat de arbeidsplaatsen van werkenden die met pensioen gaan, arbeidsongeschikt worden of zich (tijdelijk) terugtrekken van de arbeidsmarkt opnieuw moeten worden opgevuld. Vertrek van werkenden dat niet leidt tot vraag naar nieuwkomers uit hetzelfde opleidingstype wordt niet meegerekend als vervangingsvraag. 
Tabel 3.25

Verwachte baanopeningen per opleidingstype, 1997-2002

Opleidingstype

aantal

$\begin{array}{rr}\text { totaal } & \text { gemiddeld } \\ \% & \text { jaarlijks } \%\end{array}$

typering

\section{BASISONDERWIJS}

\section{Basisonderwijs}

MAVO, VBO

MAVO
MAVO

VBO Landbouw en natuurlijke omgeving

VBO landbouw en natuurlijke omgeving

VBO Techniek

VBO bouwtechniek

VBO installatietechniek

VBO mechanische techniek

VBO fijnmechanische techniek

VBO motorvoertuigentechniek

VBO elektrotechniek

VBO grafische techniek

VBO brood en banket

VBO horeca en levensmiddelentechniek

VBO vervoer

\section{VBO Economie \\ VBO administratie, handel en textiel}

VBO Verzorging

VBO verzorging

VBO Openbare orde en veiligheid

VBO beveiliging

HAVOIVWO, MBO/LLW

HAVONWO

HAVONWO

143.600

$\mathrm{MBO} / L L W$
$\mathrm{M}$ milieu en groene ruimte

MBO/LLW Techniek

MBO/LLW laboratorium

MBO/LLW bouw

MBO/LLW grond-, weg- en waterbouw

MBO/LLW installatietechniek

MBO/LLW werktuigbouw en mechanische techniek

MBO/LLW fijnmechanische techniek

MBO/LLW motorvoertuigentechniek

MBO/LLW vliegtuigtechniek

MBO/LLW operationele techniek

$\mathrm{MBO} / \mathrm{LLW}$ elektrotechniek

MBO/LLW grafische techniek

MBO/LLW procestechniek
15.200

30.700

2.900

30.600

1.000

8.400

17.400

1.900

2.500

8.200

8.700

23.200

51.900

29

5.000

43

45

37.800

8.900

23

$4,3 \quad$ laag

6,8 gemiddeld

$3,8 \quad$ laag

$4,3 \quad$ laag

5,2 gemiddeld

4,8 gemiddeld

3,5 laag

3,8 laag

5,0 gemiddeld

5,8 gemiddeld

3,7 laag

5,0 gemiddeld

4,3 gemiddeld

$3,6 \quad$ laag

5,2 gemiddeld

7,7 gemiddeld

9.000

58.800

8.800

8.000

43.800

3.700

27.100

1.700

3.200

49.500

7.400

10.100
8,3 gemiddeld

6,4 gemiddeld

7,0 gemiddeld

9,0 hoog

8,0 gemiddeld

6,7 gemiddeld

6,2 gemiddeld

5,8 gemiddeld

4,9 gemiddeld

7,1 gemiddeld

4,9 gemiddeld

8,0 gemiddeld

5,9 gemiddeld

3,5 laag

7,5 gemiddeld 
MBO/LLW brood en banket

$\mathrm{MBO} / \mathrm{LLW}$ levensmiddelentechniek/vleesverwerking

MBO/LLW Dienstverlening en gezondheidszorg

MBO dokters-, tandarts- en dierenartsassistent

MBO/LLW apothekersassistent

$\mathrm{MBO} / \mathrm{LLW}$ verpleging

MBO sociaal-cultureel

MBO/LLW verzorging

$\mathrm{MBO} / \mathrm{LLW}$ uiterlijke verzorging

MBO/LLW horeca

$\mathrm{MBO} / \mathrm{LL} W$ beweging en therapie

\section{MBO/LLW Economie}

MBO/LLW administratie

MBO/LLW handel

MBO/LLW secretariaat

$\mathrm{MBO} / \mathrm{LW}$ toerisme en recreatie

MBO Openbare orde en veiligheid

MBO openbare orde en veiligheid
$\mathrm{MBO} / \mathrm{LLW}$ vervoer

2.800

8.900

19.700

19

39

37

3,6

7,2

6,9

laag

gemiddeld

gemiddeld

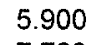

7.700

28

47.200

26.500

39.200

23.500

33.200

8.000

87.900

73.600

42.100

5.100

24.800

27

5,2 gemiddeld

8,3 hoog

7,3 gemiddeld

8,2 gemiddeld

3,9 laag

7,2 gemiddeld

8,1 gemiddeld

5,8 gemiddeld

5,9 gemiddeld

4,8 gemiddeld

7,6 gemiddeld

5,3 gemiddeld

4,9 gemiddeld

\section{HBO}

$H B O$ Onderwijs en tolk en vertaler

HBO lerarenopleiding basisonderwijs

HBO lerarenopleiding talen

47.700

8.300

9.300

HBO lerarenopleiding natuur en techniek

13.200

$\mathrm{HBO}$ lerarenopleiding economie en maatschappij

2.600

HBO lerarenopleiding lichamelijke opvoeding

$\mathrm{HBO}$ lerarenopleiding medisch en verzorging

3.400

HBO lerarenopleiding expressie

HBO tolk en vertaler

8.300

2.900

30

27

26

37

17

24

27

31

4.800

57

4.600

5,6

4,9

4,8

6,8

3,2

4,5

5,0

5,8

gemiddeld

gemiddeld

gemiddeld

gemiddeld

laag gemiddeld gemiddeld

HBO Landbouw

$H B O$ landbouw en veeteelt

HBO milieukunde en levensmiddelentechnologie

10,2 hoog

5,9 gemiddeld

8.900

24

8.300

43

5.200

13.600

11.600

15.300

3.400

8.200

30

HBO informatica

HBO chemische technologie

HBO vervoer en logistiek

20.600

15.000

1.800

$H B O$ verpleegkunde

HBO (fysio)therapie

$H B O$ voeding
37

28

41

39

4,3 gemiddeld

7,9 gemiddeld

5,7 gemiddeld

6,9 gemiddeld

5,4 gemiddeld

7,6 gemiddeld

7,7 gemiddeld

6,5 gemiddeld

7,3 gemiddeld

7,3 gemiddeld

6,9 gemiddeld 
Tabe/ 3.25 (vervolg)

Verwachte baanopeningen per opleidingstype, 1997-2002

Opleidingstype

aantal

totaal gemiddeld

$\%$ jaarlijks \%

typering

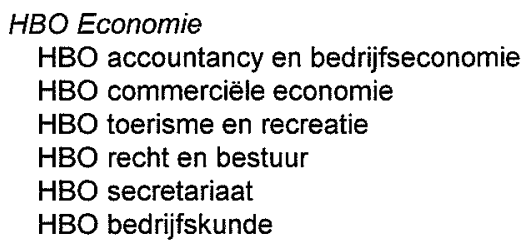

$\begin{array}{rlll}22.000 & 38 & 7,0 & \text { gemiddeld } \\ 19.800 & 47 & 8,7 & \text { hoog } \\ 4.600 & 50 & 9,2 & \text { hoog } \\ 11.300 & 52 & 9,3 & \text { hoog } \\ 12.100 & 39 & 7,2 & \text { gemiddeld } \\ 29.300 & 45 & 8,3 & \text { gemiddeld }\end{array}$

HBO Sociaal-cultureel

HBO communicatie en journalistiek

7.000

7,8 gemiddeld

HBO maatschappelijk werk en hulpverlening

22.900

$\mathrm{HBO}$ personeelswerk

3.300

43

$\mathrm{HBO}$ bibliotheek en documentatie

5.500

31
17

5,8

3,2

gemiddeld

HBO Kunst

HBO uitvoerende en beeldende kunsten

18.900

40

7,4

laag

40

gemiddeld

HBO Openbare orde en veiligheid

HBO openbare orde en veiligheid

2.800

7,5 gemiddeld

5,2 gemiddeld

wo

WO Letteren en theologie

WO letteren

20.200

45

1.500

27

8,2 gemiddeld

WO theologie

$3.100 \quad 25$

4,8 gemiddeld

WO Landbouw en milieukunde

WO landbouw en milieukunde

25

4,9 gemiddeld

WO Techniek

WO wiskunde en natuurwetenschappen

18.800

4.900

30

WO bouwkunde

3.400

52

WO civiele techniek

3.000

3.100

WO elektrotechniek

5.500

48

30

WO informatica en bestuurlijke informatiekunde

34

69

9.800

22

2.100

900

33

WO (dier)geneeskund
WO tandheelkunde

WO farmacie

13

5,7 gemiddeld

9,5 hoog

8,8 hoog

5,7 gemiddeld

6,4 gemiddeld

11,6 erg hoog

\section{WO Economie}

WO econom(etr)ie

24.500

13.500

58

10.600

64

WO accountancy en belastingen

18.400

57

WO rechten en bestuurskunde

33.200

40

$\begin{array}{ll}4,2 & \text { laag } \\ 6,1 & \text { gemiddeld } \\ 2,5 & \text { laag }\end{array}$

WO Sociaal-cultureel

WO sociale wetenschappen

$\begin{aligned} 10,4 & \text { erg hoog } \\ 11,2 & \text { erg hoog } \\ 10,3 & \text { hoog } \\ 6,0 & \text { gemiddeld }\end{aligned}$

7,4 gemiddeld 
Tabel 3.25 (vervolg)

Verwachte baanopeningen per opleidingstype, 1997-2002

\begin{tabular}{lrrrr} 
Opleidingstype & aantal & $\begin{array}{r}\text { totaal } \\
\%\end{array}$ & $\begin{array}{c}\text { gemiddeld } \\
\text { jaarlijks } \%\end{array}$ & typering \\
\hline $\begin{array}{l}\text { WO Kunst } \\
\text { WO kunstwetenschappen }\end{array}$ & 1.600 & 33 & 6,3 & gemiddeld \\
$\begin{array}{l}\text { Totaal } \\
\text { 2.052.400 }\end{array}$ & 32 & 5,8 & gemiddeld \\
\hline
\end{tabular}

\section{Bron: ROA}

Toelichting:

Baanopeningen zijn de totale vraag naar nieuwkomers op de arbeidsmarkt, zoals deze is bepaald door de werkgelegenheidsgroei (positieve uitbreidingsvraag) en de vervangingsvraag. 
Verwachte instroom van schoolverlaters per opleidingstype, 1997-2002

Opleidingstype

aantal totaal gemiddeld

typering

$\%$ jaarlijks \%

\section{BASISONDERWIJS}

Basisonderwijs

122.400

26

$4,7 \quad$ gemiddeld

MAVO, VBO

MAVO

90.300

22

4,1 gemiddeld

VBO Landbouw en natuurlijke omgeving

VBO landbouw en natuurlijke omgeving

10.800

14

$2,7 \quad$ laag

VBO Techniek

VBO bouwtechniek

20.800

4.600

18.300

VBO mechanische techniek

VBO fijnmechanische techniek

300

VBO motorvoertuigentechniek

8.800

8.100

1.700

VBO grafische techniek

4.100

VBO brood en banket

VBO horeca en levensmiddelentechniek

11.200

VBO vervoer

4.200

35.600

30

2,9 gemiddeld

7,9 erg hoog

3,0 gemiddeld

1,1 erg laag

3,9 gemiddeld

2,4 laag

5,2 hoog

5,8 hoog

6,7 hoog

2,2 laag

VBO Economie

VBO administratie, handel en textiel

36.000

20

5,3 hoog

VBO Verzorging

VBO verzorging

3,7

gemiddeld

VBO Openbare orde en veiligheid

VBO beveiliging

3.300

28

5,1 hoog

HAVO/VWO, MBO/LLW

HAVO/WWO
HAVO/WWO
MBO/LLW Landbouw en natuurlijke omgeving
MBO/LLW landbouw en veeteelt
MBO/LLW milieu en groene ruimte
MBO/LLW Techniek
MBO/LLW laboratorium
MBO/LLW bouw
MBO/LLW grond-, weg- en waterbouw
MBO/LLW installatietechniek
MBO/LLW werktuigbouw en mechanische techniek
MBO/LLW fijnmechanische techniek
MBO/LLW motorvoertuigentechniek
MBO/LLW vliegtuigtechniek
MBO/LLW operationele techniek
MBO/LLW elektrotechniek
MBO/LLW grafische techniek
MBO/LLW procestechniek

148.900

46

7,9 erg hoog

21.500

6.700

3,6

gemiddeld

5,1 hoog

erg hoog gemiddeld gemiddeld gemiddeld gemiddeld gemiddeld gemiddeld gemiddeld laag gemiddeld gemiddeld laag 


\begin{tabular}{|c|c|c|c|}
\hline Opleidingstype & aantal & $\begin{array}{r}\text { totaal } \\
\%\end{array}$ & $\begin{array}{l}\text { gemiddeld } \\
\text { jaarilijks } \%\end{array}$ \\
\hline
\end{tabular}

\author{
MBO/LLW brood en banket \\ MBO/LLW levensmiddelentechniek/vleesverwerking \\ $\mathrm{MBO} / L L W$ vervoer
}

MBO/LLW Dienstverlening en gezondheidszorg

MBO dokters-, tandarts- en dierenartsassistent

MBO/LLW apothekersassistent

$M B O / L L W$ verpleging

MBO sociaal-cultureel

$M B O / L L W$ verzorging

MBO/LLW uiterlijke verzorging

MBO/LLW horeca

MBO/LLW beweging en therapie
MBO/LLW Economie
MBO/LLW administratie
MBO/LLW handel
MBO/LLW secretariaat
MBO/LLW toerisme en recreatie
$M B O$ Openbare orde en veiligheid
MBO openbare orde en veiligheid

$\begin{array}{rlll}3.100 & 21 & 3,9 & \text { gemiddeld } \\ 6.600 & 29 & 5,2 & \text { hoog } \\ 10.900 & 20 & 3,8 & \text { gemiddeld }\end{array}$

$\begin{array}{rrrl}7.600 & 36 & 6,3 & \text { hoog } \\ 6.400 & 38 & 6,6 & \text { hoog } \\ 9.400 & 8 & 1,5 & \text { laag } \\ 25.100 & 42 & 7,3 & \text { erg hoog } \\ 46.800 & 25 & 4,5 & \text { gemiddeld } \\ 11.400 & 19 & 3,5 & \text { gemiddeld } \\ 14.500 & 19 & 3,6 & \text { gemiddeld } \\ 9.300 & 35 & 6,3 & \text { hoog }\end{array}$

$58.600 \quad 21$

$64.900 \quad 22$

$18.300 \quad 18$

$10.000 \quad 54$

10.400

11

$2,1 \quad$ laag

HBO

HBO Onderwijs en tolk en vertaler

HBO lerarenopleiding basisonderwijs

HBO lerarenopleiding talen

$17.100 \quad 11$

$3.300 \quad 11$

HBO lerarenopleiding natuur en techniek

2.700

4.700

1.800

HBO lerarenopleiding lichamelijke opvoeding

$\mathrm{HBO}$ lerarenopleiding medisch en verzorging

700

HBO lerarenopleiding expressie

$\mathrm{HBO}$ tolk en vertaler

$6.100 \quad 20$

600

$2,1 \quad$ laag

2,1 laag

1,5 laag

2,5 laag

2,3 laag

1,0 erg laag

HBO Landbouw

$H B O$ landbouw en veeteelt

HBO milieukunde en levensmiddelentechnologie

$2.400 \quad 29$

$5.600 \quad 38$

5,3 hoog

6,6 hoog

HBO Techniek

HBO laboratorium

$6.100 \quad 16$

3,0

gemiddeld

HBO bouwkunde

$3.700 \quad 19$

3,5

gemiddeld

HBO civiele techniek

$2.400 \quad 14$

$8.300 \quad 23$

$8.100 \quad 20$

HBO elektrotechniek

$7.400 \quad 20$

HBO informatica

HBO chemische technologie

HBO vervoer en logistiek

1.600

19

$1.900 \quad 8$

2,6

4,2

laag

gemiddeld

3,6 gemiddeld

3,7 gemiddeld

$3,6 \quad$ gemiddeld

1,5 laag

HBO Paramedisch

HBO verpleegkunde

HBO (fysio)therapie

$10.600 \quad 20$

$H B O$ voeding

9.300

25

$1.700 \quad 36$

$3,7 \quad$ gemiddeld

4,5 gemiddeld

6,3 hoog 
HBO Economie

HBO accountancy en bedrijfseconomie

HBO commerciële economie

HBO toerisme en recreatie

HBO recht en bestuur

HBO secretariaat

$\mathrm{HBO}$ bedrijfskunde

HBO Sociaal-cultureel

HBO communicatie en journalistiek

$\mathrm{HBO}$ maatschappelijk werk en hulpverlening

$\mathrm{HBO}$ personeelswerk

HBO bibliotheek en documentatie

HBO Kunst

HBO uitvoerende en beeldende kunsten

12.700

27

2.200

22

HBO openbare orde en veiligheid

wo

WO Letteren en theologie

WO letteren

WO theologie

WO Landbouw en milieukunde

WO landbouw en milieukunde

3.500

29

13.800

2.000

1.000

3.300

1.800

3.000

WO informatica en bestuurlijke informatiekunde

WO Medisch

WO (dier)geneeskunde

WO tandheelkunde

WO farmacie

6.600

400

1.100

22

21

14

35

20

38

16.700

6.300

900

19.000

WO econom(etr)ie
WO bedrijfskunde
WO accountancy en belastingen
WO rechten en bestuurskunde

WO econom(etr)ie
WO bedrijfskunde
WO accountancy en belastingen
WO rechten en bestuurskunde

WO Sociaal-cultureel

WO sociale wetenschappen

33

48

44

1

18

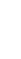

34

34
21
46

6

20

5,8 hoog

8,2 erg hoog

7,6 erg hoog

0,2 erg laag

3,4 gemiddeld

7,1 erg hoog

6,0 hoog

3,9 gemiddeld

7,9 erg hoog

3,7 gemiddeld

4,9 hoog

4,1 gemiddeld

WO Economie

33

15

7

15

6,2 hoog

2,0 laag

5,2 hoog

4,1 gemiddeld

3,9 gemiddeld

2,7 laag

6,1 hoog

3,7 gemiddeld

6,6 hoog

$26.700 \quad 32$
2,8 gemiddeld

1,3 laag

2,9 gemiddeld

6,9 erg hoog

5,4 hoog

1,0 erg laag

5,9 hoog

5,8 hoog 
Tabel 3.26 (vervolg)

Verwachte instroom van schoolverlaters per opleidingstype, 1997-2002

Opleidingstype

aantal totaal gemiddeld

typering

$\% \quad$ jaarlijks $\%$

WO Kunst

WO kunstwetenschappen

2.100

44

$7,6 \quad$ erg hoog

Totaal

1.394 .100

22

4,1 gemiddeld

Bron: ROA

Toelichting:

De instroom is het verwachte aanbod van nieuwe arbeidskrachten op de arbeidsmarkt. Deze is gebaseerd op de verwachte uistroom van schoolverlaters uit het initiële dagonderwijs, het deeltijdonderwijs, het nietreguliere voltijdonderwijs en de beroepsgerichte volwasseneducatie. 
Tabel 3.27

Indicator toekomstige arbeidsmarktperspectieven (ITA) en Indicator toekomstige knelpunten in de personeelsvoorziening (ITKP) naar opleidingstype in 2002

Opleidingstype

ITA

typering
arbeidsmarkt-
perspectief

typering

knelpunten

\section{BASISONDERWIJS}

\begin{tabular}{|c|c|c|c|c|}
\hline Basisonderwijs & 1,08 & matig & 1,25 & geen \\
\hline \multicolumn{5}{|l|}{ MAVO, VBO } \\
\hline \multicolumn{5}{|l|}{ MAVO } \\
\hline MAVO & 0,97 & goed & 0,97 & groot \\
\hline \multicolumn{5}{|l|}{ VBO Landbouw en natuurlijke omgeving } \\
\hline VBO landbouw en natuurlijke omgeving & 0,98 & goed & 1,15 & vrijwel geen \\
\hline \multicolumn{5}{|l|}{ VBO Techniek } \\
\hline VBO bouwtechniek & 1,03 & redelijk & 1,03 & enige \\
\hline VBO installatietechniek & 1,23 & slecht & 1,23 & geen \\
\hline VBO mechanische techniek & 0,98 & goed & 1,06 & vrijwel geen \\
\hline VBO fijnmechanische techniek & 0,94 & goed & 1,01 & enige \\
\hline VBO motorvoertuigentechniek & 1,05 & redelijk & 1,16 & geen \\
\hline VBO elektrotechniek & 0,93 & goed & 0,93 & groot \\
\hline VBO grafische techniek & 1,00 & goed & 1,15 & vrijwel geen \\
\hline VBO brood en banket & 1,15 & matig & 1,30 & geen \\
\hline VBO horeca en levensmiddelentechniek & 1,17 & slecht & 1,23 & geen \\
\hline VBO vervoer & 0,94 & goed & 1,00 & groot \\
\hline \multicolumn{5}{|l|}{ VBO Economie } \\
\hline VBO administratie, handel en textiel & 1,17 & slecht & 1,31 & geen \\
\hline \multicolumn{5}{|l|}{ VBO Verzorging } \\
\hline VBO verzorging & 1,02 & redelijk & 1,03 & enige \\
\hline \multicolumn{5}{|l|}{ VBO Openbare orde en veiligheid } \\
\hline VBO beveiliging & 0,94 & goed & 0,94 & groot \\
\hline \multicolumn{5}{|l|}{ HAVONWO, MBO/LLW } \\
\hline \multicolumn{5}{|l|}{ HAVONWO } \\
\hline HAVONWO & 1,05 & redelijk & 1,05 & enige \\
\hline \multicolumn{5}{|l|}{ MBO/LWW Landbouw en natuurlijke omgeving } \\
\hline MBO/LLW landbouw en veeteelt & 0,93 & goed & 0,93 & groot \\
\hline MBO/LLW milieu en groene ruimte & 0,96 & goed & 0,96 & groot \\
\hline \multicolumn{5}{|l|}{ MBO/LLW Techniek } \\
\hline MBO/LLW laboratorium & 0,96 & goed & 0,96 & groot \\
\hline MBO/LLW bouw & 0,87 & goed & 0,87 & groot \\
\hline MBO/LLW grond-, weg- en waterbouw & 0,90 & goed & 0,90 & groot \\
\hline MBO/LLW installatietechniek & 0,92 & goed & 0,92 & groot \\
\hline MBO/LLW werktuigbouw en mechanische techniek & 0,95 & goed & 0,95 & groot \\
\hline MBO/LLW fijnmechanische techniek & 0,93 & goed & 0,93 & groot \\
\hline MBO/LLW motorvoertuigentechniek & 0,91 & goed & 0,91 & groot \\
\hline MBO/LLW vliegtuigtechniek & 0,94 & goed & 1,02 & enige \\
\hline MBO/LLW operationele techniek & 0,80 & zeer goed & 0,80 & zeer groot \\
\hline
\end{tabular}


Tabe/ 3.27 (vervolg)

Indicator toekomstige arbeidsmarktperspectieven (ITA) en Indicator toekomstige knelpunten in de personeelsvoorziening (ITKP) naar opleidingstype in 2002

Opleidingstype
ITA

$\begin{array}{lll}\text { typering } & \text { ITKP } & \text { typering } \\ \text { arbeidsmarkt- } & & \text { knelpunten } \\ \text { perspectief } & & \end{array}$

\begin{tabular}{|c|c|c|c|c|}
\hline MBO/LLW elektrotechniek & 0,93 & goed & 0,93 & groot \\
\hline MBO/LLW grafische techniek & 1,07 & matig & 1,07 & vrijwel geen \\
\hline MBO/LLW procestechniek & 0,81 & zeer goed & 0,81 & zeer groot \\
\hline MBO/LLW brood en banket & 1,03 & redelijk & 1,05 & enige \\
\hline MBO/LLW levensmiddelentechniek/ & & & & \\
\hline vleesverwerking & 0,99 & goed & 0,99 & groot \\
\hline MBO/LLW vervoer & 0,93 & goed & 0,93 & groot \\
\hline \multicolumn{5}{|l|}{ MBO $L L W$ Dienstverlening en gezondheidszorg } \\
\hline MBO dokters-, tandarts- en dierenartsassistent & 1,11 & matig & 1,11 & vrijwel geen \\
\hline MBO/LLW apothekersassistent & 0,97 & goed & 0,97 & groot \\
\hline $\mathrm{MBO} / \mathrm{LLW}$ verpleging & 0,81 & zeer goed & 0,81 & zeer groot \\
\hline MBO sociaal-cultureel & 1,01 & redelijk & 1,01 & enige \\
\hline MBO/LLW verzorging & 1,07 & matig & 1,07 & vrijwel geen \\
\hline MBO/LLW uiterlijke verzorging & 0,88 & goed & 0,88 & groot \\
\hline MBO/LLW horeca & 0,85 & zeer goed & 0,85 & zeer groot \\
\hline MBO/LLW beweging en therapie & 1,07 & matig & 1,07 & vrijwel geen \\
\hline \multicolumn{5}{|l|}{ MBOLLWEConomie } \\
\hline MBO/LLW administratie & 0,96 & goed & 0,96 & groot \\
\hline MBO/LLW handel & 1,02 & redelijk & 1,02 & enige \\
\hline MBO/LLW secretariaat & 0,89 & goed & 0,89 & groot \\
\hline MBO/LLW toerisme en recreatie & 1,29 & slecht & 1,29 & geen \\
\hline \multicolumn{5}{|l|}{ MBO Openbare orde en veiligheid } \\
\hline MBO openbare orde en veiligheid & 0,88 & goed & 0,88 & groot \\
\hline \multicolumn{5}{|l|}{ HBO } \\
\hline \multicolumn{5}{|l|}{ HBO Onderwijs en tolk en vertaler } \\
\hline HBO lerarenopleiding basisonderwijs & 0,87 & goed & 0,87 & groot \\
\hline HBO lerarenopleiding talen & 0,88 & goed & 0,96 & groot \\
\hline HBO lerarenopleiding natuur en techniek & 0,86 & goed & 0,86 & groot \\
\hline HBO lerarenopleiding economie en maatschappij & 0,85 & zeer goed & 0,85 & zeer groot \\
\hline HBO lerarenopleiding lichamelijke opvoeding & 0,96 & goed & 0,96 & groot \\
\hline HBO lerarenopleiding medisch en verzorging & 0,87 & goed & 0,87 & groot \\
\hline HBO lerarenopleiding expressie & 0,98 & goed & 0,98 & groot \\
\hline $\mathrm{HBO}$ tolk en vertaler & 0,90 & goed & 0,90 & groot \\
\hline \multicolumn{5}{|l|}{ HBO Landbouw } \\
\hline HBO landbouw en veeteelt & 0,85 & zeer goed & 0,85 & zeer groot \\
\hline HBO milieukunde en levensmiddelentechnologie & 1,07 & matig & 1,07 & vrijwel geen \\
\hline \multicolumn{5}{|l|}{ HBO Techniek } \\
\hline HBO laboratorium & 0,96 & goed & 0,96 & groot \\
\hline HBO bouwkunde & 0,83 & zeer goed & 0,83 & zeer groot \\
\hline HBO civiele techniek & 0,86 & goed & 0,86 & groot \\
\hline HBO werktuigbouwkunde & 0,88 & goed & 0,88 & groot \\
\hline HBO elektrotechniek & 0,93 & goed & 0,93 & groot \\
\hline HBO informatica & 0,85 & zeer goed & 0,85 & zeer groot \\
\hline HBO chemische technologie & 0,86 & goed & 0,86 & groot \\
\hline HBO vervoer en logistiek & 0,80 & zeer goed & 0,80 & zeer groot \\
\hline
\end{tabular}


Tabel 3.27 (vervolg)

Indicator toekomstige arbeidsmarktperspectieven (ITA) en Indicator toekomstige kans op knelpunten in de personeelsvoorziening (ITKP) naar opleidingstype in 2002

Opleidingstype

ITA

typering ITKP

typering

perspectief

\section{HBO Paramedisch \\ $\mathrm{HBO}$ verpleegkunde \\ $\mathrm{HBO}$ (fysio)therapie \\ $\mathrm{HBO}$ voeding}

\section{HBO Economie}

$\mathrm{HBO}$ accountancy en bedrijfseconomie

HBO commerciële economie

HBO toerisme en recreatie

HBO recht en bestuur

HBO secretariaat

$\mathrm{HBO}$ bedrijfskunde

\section{HBO Sociaal-cultureel}

HBO communicatie en journalistiek

HBO maatschappelijk werk en hulpveriening

HBO personeelswerk

$\mathrm{HBO}$ bibliotheek en documentatie

\section{HBO Kunst}

$\mathrm{HBO}$ uitvoerende en beeldende kunsten

HBO Openbare orde en veiligheid

$\mathrm{HBO}$ openbare orde en veiligheid

\section{wo}

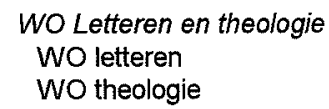

WO Landbouw en milieukunde

WO landbouw en milieukunde

\section{WO Techniek}

WO wiskunde en natuurwetenschappen

WO bouwkunde

WO civiele techniek

WO werktuigbouwkunde

WO elektrotechniek

WO informatica en bestuurlijke informatiekunde

WO Medisch

WO (dier)geneeskunde

WO tandheelkunde

WO farmacie

\section{WO Economie \\ WO econom(etr)ie \\ WO bedrijfskunde \\ WO accountancy en belastingen \\ WO rechten en bestuurskunde}

$\begin{array}{llll}0,87 & \text { goed } & 0,87 & \text { groot } \\ 0,92 & \text { goed } & 0,92 & \text { groot } \\ 1,00 & \text { goed } & 1,00 & \text { groot } \\ & & & \\ 0,95 & \text { goed } & 0,95 & \text { groot } \\ 1,02 & \text { redelijk } & 1,02 & \text { enige } \\ 1,03 & \text { redelijk } & 1,03 & \text { enige } \\ 0,69 & \text { zeer goed } & 0,69 & \text { zeer g } \\ 0,88 & \text { goed } & 0,88 & \text { groot } \\ 0,97 & \text { goed } & 0,97 & \text { groot } \\ & & & \\ 0,98 & \text { goed } & 0,98 & \text { groot } \\ 0,97 & \text { goed } & 0,97 & \text { groot } \\ 1,25 & \text { slecht } & 1,27 & \text { geen } \\ 0,91 & \text { goed } & 0,91 & \text { groot } \\ & & & \\ 0,95 & \text { goed } & 0,95 & \text { groot } \\ & & & \\ 0,92 & \text { goed } & 0,92 & \text { groot }\end{array}$

0,95

0,88

goed

0,95

groot

goed

1,00 groot

1,01

redelijk

1,01

enige

0,94

goed

0,94

0,78

0,73

0,95

0,87

0,78 zeer goed $\quad 0,78$ zeer groot

0,78 zeer goed $\quad 0,78 \quad$ zeer groot

groot

zeer groot

zeer groot

groot

groot

0,96

goed

0,96

0,81

0,81

zeer goed

groot

zeer groot

enige

$\begin{array}{llll}0,87 & \text { goed } & 0,87 & \text { groot } \\ 0,78 & \text { zeer goed } & 0,78 & \text { zeer groot } \\ 0,67 & \text { zeer goed } & 0,67 & \text { zeer groot } \\ 0,97 & \text { goed } & 0,97 & \text { groot }\end{array}$


Indicator toekomstige arbeidsmarktperspectieven (ITA) en Indicator toekomstige knelpunten in de personeelsvoorziening (ITKP) naar opleidingstype in 2002

Opleidingstype

ITA

typering

arbeidsmarkt-

perspectief
ITKP typering

knelpunten

\section{WO Sociaal-cultureel}

WO sociale wetenschappen

0,95

goed

0,95

groot

Wo Kunst

WO kunstwetenschappen

$1,13 \quad$ matig

1,13 vrijwel geen

Bron: ROA

\section{Toelichting:}

Het toekomstig arbeidsmarktperspectief geeft de verhouding tussen aanbod en vraag in de prognoseperiode naar een opleidingstype weer. Het aanbod is opgebouwd uit de verwachte instroom van schoolverlaters en het aantal kortdurig werklozen. De vraag bestaat uit de verwachte baanopeningen en de substitutievraag. Net als de ITA geeft ook de ITKP deze vraag-aanbod-spanning aan. Verschil met de ITA is dat bij de ITKP de uitstroom van werkenden als gevolg van een krimpende werkgelegenheid is meegerekend in de vraag, omdat verwacht mag worden dat bij knelpunten in de personeelsvoorziening deze (gedwongen) uitstroom kan worden afgeremd of elders werk zou kunnen vinden. 
Statistische Bijlage

De Arbeidsmarkt naar Opleiding en Beroep tot 2002

\section{Errata behorende bij pagina 23}

Tabel 1.12

Verwachte uitbreidingsvraag per bedrijfssector, 1997-2002

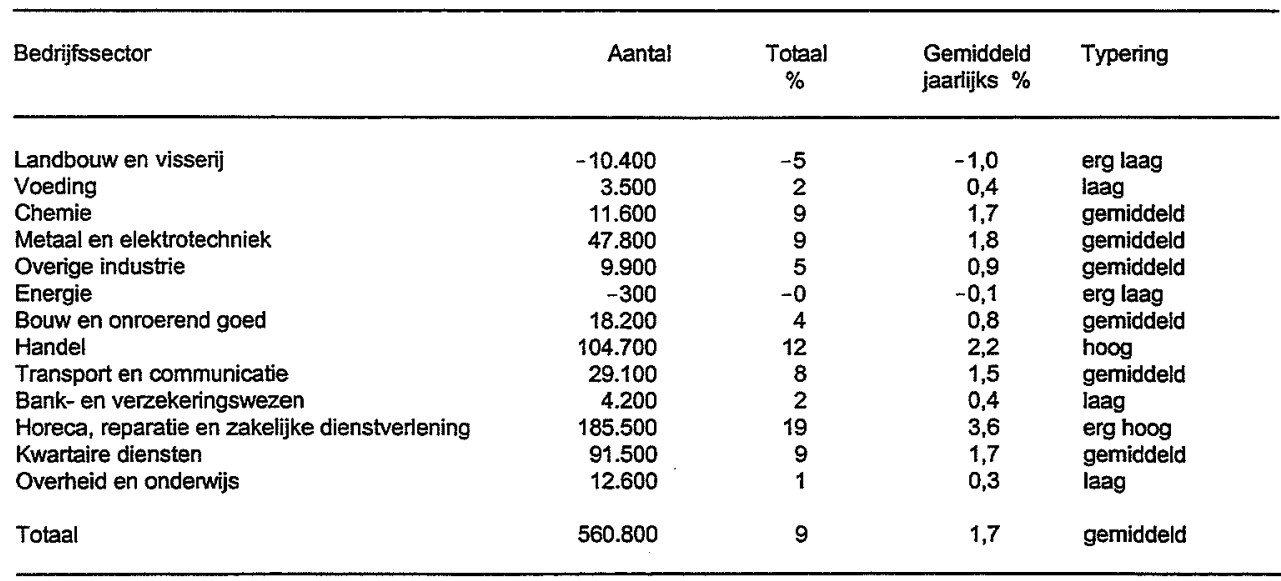

